Documentation of the Native American Ceramic Vessels from Northeastern Texas, Southern Arkansas, and Eastern Oklahoma in the Boyce Smith Museum in Troup, Texas

Timothy K. Perttula

Heritage Research Center, Stephen F. Austin State University

Mark Walters

Heritage Research Center, Stephen F. Austin State University

Bo Nelson

Heritage Research Center, Stephen F. Austin State University

Follow this and additional works at: https://scholarworks.sfasu.edu/ita

Part of the American Material Culture Commons, Archaeological Anthropology Commons, Environmental Studies Commons, Other American Studies Commons, Other Arts and Humanities Commons, Other History of Art, Architecture, and Archaeology Commons, and the United States History Commons

Tell us how this article helped you.

This Article is brought to you for free and open access by the Center for Regional Heritage Research at SFA ScholarWorks. It has been accepted for inclusion in Index of Texas Archaeology: Open Access Gray Literature from the Lone Star State by an authorized editor of SFA ScholarWorks. For more information, please contact cdsscholarworks@sfasu.edu. 
Documentation of the Native American Ceramic Vessels from Northeastern

Texas, Southern Arkansas, and Eastern Oklahoma in the Boyce Smith Museum in Troup, Texas

Creative Commons License

(c) (1) (9)

This work is licensed under a Creative Commons Attribution-NonCommercial 4.0 International License 


\section{DOCUMENTATION OF THE NATIVE AMERICAN CERAMIC VESSELS FROM NORTHEAST TEXAS, SOUTHERN ARKANSAS, AND EASTERN OKLAHOMA IN THE BOYCE SMITH MUSEUM IN TROUP, TEXAS}

Timothy K. Perttula, Mark Walters, and Bo Nelson

Special Publication No. 8

Friends of Northeast Texas Archaeology 


\section{TABLE OF CONTENTS}

List of Figures $\quad 3$

$\begin{array}{ll}\text { List of Tables } & 6\end{array}$

$\begin{array}{ll}\text { Introduction } & 7\end{array}$

Methods of Vessel Documentation $\quad 8$

Northeastern Texas Counties with Vessels $\quad 12$

Red River County $\quad 12$

$\begin{array}{lr}\text { Bowie County } & 18\end{array}$

Harrison County 19

Marion County 21

Camp County $\quad 22$

$\begin{array}{ll}\text { Upshur County } & 23\end{array}$

$\begin{array}{ll}\text { Cherokee County } & 24\end{array}$

$\begin{array}{ll}\text { Smith County } & 24\end{array}$

Southern Arkansas Counties with Vessels 26

$\begin{array}{ll}\text { Clark County } & 26\end{array}$

$\begin{array}{ll}\text { Pike County } & 27\end{array}$

Unknown County 28

Southern Arkansas $\quad 28$

Faulkner County 28

Lee County 28

$\begin{array}{ll}\text { Grant County } & 29\end{array}$

$\begin{array}{lr}\text { Eastern Oklahoma } & 29\end{array}$

$\begin{array}{ll}\text { Spiro Site, LeFlore County } & 29\end{array}$

$\begin{array}{lr}\text { Pipes } & 29\end{array}$

Regional and Temporal Comparisons 31

Summary and Conclusions 36

$\begin{array}{ll}\text { References Cited } & 37\end{array}$ 


\section{LIST OF FIGURES}

Figure 1. Northeastern Texas, southern Arkansas, and eastern Oklahoma counties represented by ceramic vessels in the Boyce Smith Museum.

Figure 2. Tall jars from Red River County: a, Nash Neck Banded (Vessel 63); b, Pinchedpunctated (Vessel 89)

Figure 3. Decorated jars with rim peaks from Red River County: a, neck bandedappliqued-punctated (Vessel 39); b, Boyce appliqued-punctated (Vessel 31); c, Boyce appliqued-punctated (Vessel 57); d, Boyce appliqued-punctated (Vessel 36); e, Boyce appliqued-punctated (Vessel 54); f, Boyce appliqued-punctated (Vessel 10); g, pinchedpunctated (Vessel 84); h, Boyce appliqued-punctated (Vessel 99); i, Boyce appliquedpunctated (Vessel 100); j, conjoined Boyce appliqued-punctated jars (Vessel 118).

Figure 4. Pinched and punctated jars from Red River County: a, pinched-incised (Vessel 15); b, pinched-punctated-grooved (Vessel 45); c, pinched-appliqued-punctated-grooved (Vessel 113); d, punctated (Vessel 61); e, punctated-incised-appliqued-grooved (Vessel 93); f, pinched-punctated-incised (Vessel 115).

Figure 5. Other decorated jars from Red River County: a, pinched (Vessel 112); b, punctated-appliqued-incised (Vessel 73); c, incised-appliqued-punctated (Vessel 85); d, incised-punctated-appliqued (Vessel 121).

Figure 6. Bowls from Red River County: a, Avery Engraved deep bowl (Vessel 127); b, incised bowl (Vessel 4); c, incised effigy bowl with tail rider (Vessel 82); d, incised bird effigy bowl (Vessel 42).

Figure 7. Rattle bowls and canoe-shaped bowl from Red River County: a, incised rattle bowl (Vessel 90); b, pinched rattle bowl (Vessel 92); c, engraved canoe-shaped bowl (Vessel 80).

Figure 8. Carinated bowls and compound bowl from Red River County: a, cf. Pennington Punctated-Incised (Vessel 116); b, Davis Incised (Vessel 95); c, engraved-appliqued carinated bowl (Vessel 98); d, Simms Engraved (Vessel 65); e, Simms Incised (Vessel 77); f, Simms Incised (Vessel 97); g, Simms Incised (Vessel 18); h, Avery Incised compound bowl (Vessel 60).

Figure 9. Bowie County vessels: a, Hatchel Engraved bottle (Vessel 105); b, engraved bowl (Vessel 29); c, engraved-punctated carinated bowl (Vessel 128); d, sprocket lip on Vessel 128.

Figure 10. Carinated bowls, compound bowls, and deep bowls from Harrison County: a, Ripley Engraved (Vessel 162); b, Ripley Engraved (Vessel 168); c, Simms Engraved (Vessel 160); d, Ripley Engraved compound bowl (Vessel 166); e, horizontal engraved deep bowl (Vessel 163). 


\section{LIST OF FIGURES, cont.}

Figure 11. Bottles and ollas from Harrison County: a, Wilder Engraved (Vessel 158); b, engraved bottle with red pigment (Vessel 153); c, bottle with engraved circles and crosses (Vessel 114); d, Wilder Engraved olla (Vessel 161).

Figure 12. Decorated jars from Harrison County: a, Harleton Appliqued (Vessel 53); b, Karnack Brushed-Incised (Vessel 21); c, Maydelle Incised (Vessel 165); d, Cowhide Stamped (Vessel 171).

Figure 13. Engraved carinated bowls from Marion County: a, Ripley Engraved (Vessel 17); b, Ripley Engraved (Vessel 49); c, diagonal engraved zones (Vessel 19).

Figure 14. Ollas from Marion County: a, Belcher Engraved miniature olla (Vessel 140); b, Clements Brushed (Vessel 138).

Figure 15. Harleton Appliqued jar from Marion County (Vessel 139).

Figure 16. Engraved fine ware vessels from Camp County: a, Ripley Engraved carinated bowl (Vessel 28); b, Ripley Engraved carinated bowl (Vessel 27); c, Taylor Engraved compound bowl (Vessel 24); d, Ripley Engraved carinated bowl (Vessel 20).

Figure 17. Decorated utility wares from Camp County: a, Harleton Appliqued jar (Vessel 164); b, Maydelle Incised jar (Vessel 145).

Figure 18. Engraved vessels from Upshur County: a, Ripley Engraved carinated bowl (Vessel 133); b, Taylor Engraved compound bowl (Vessel 144).

Figure 19. Moore Noded rattle bowl from Upshur County, Vessel 151.

Figure 20. Decorated utility ware jars from Upshur County: a, Harleton Appliqued (Vessel 135); b, Pease Brushed-Incised (Vessel 130); c, Cass Appliqued (Vessel 142); d, Cass Appliqued (Vessel 131).

Figure 21. Vessels from Cherokee County: a, opposed engraved carinated bowl (Vessel 182); b, interior engraved scalloped bowl, cf. Sanders Engraved (Vessel 4); c, Taylor Engraved olla or short-necked bottle (Vessel 189).

Figure 22. Engraved fine ware vessels from Smith County: a, Poynor Engraved, var. Hood (Vessel 22); b, Poynor Engraved, var. E (Vessel 25); c, Hume Engraved bottle (Vessel 88); d, engraved jar or beaker (Vessel 5).

Figure 23. Effigy bowls and rattle bowls from Smith County: a, Hood Engraved effigy bowl (Vessel 149); b, Hood Engraved effigy bowl (Vessel 125); c, incised four-legged rattle bowl (Vessel 51). 


\section{LIST OF FIGURES, cont.}

Figure 24. Engraved carinated bowls and beaker/compound bowl from Clark County, Arkansas: a, Friendship Engraved (Vessel 146); b, view of sprocket lip on Vessel 146; c, Friendship Engraved (Vessel 85); d, Friendship Engraved (Vessel 59); e, engraved beaker or compound bowl (Vessel 106).

Figure 25. Engraved bottles from Clark County, Arkansas: a, Friendship Engraved (Vessel 170); b, Means Engraved (Vessel 6); c, Belcher Engraved, var. Manchester (Vessel 173); d, Bottle with engraved panels (Vessel 34); e, Means Engraved? (Vessel 172); f, Hudson Engraved (Vessel 169).

Figure 26. Military Road Incised vessel from Clark County, Arkansas (Vessel 62).

Figure 27. cf. Dunkin Incised jar from Pike County, Arkansas (Vessel 107).

Figure 28. Engraved-punctated seed jar from southern Arkansas (Vessel 157).

Figure 29. Vessels from Lee and Grant counties, Arkansas: a, plain bottle, Lee County (Vessel 103); b, Grant County engraved bottle (Vessel 129).

Figure 30. Engraved bottle from the Spiro site, LeFlore County, Oklahoma (Vessel 109).

Figure 31. Clay pipes in the Boyce Smith Museum: a, Red River long-stemmed pipe, variety Haley; b, L-shaped and rounded elbow pipes; c, engraved and punctated elbow pipe; d, plain and engraved-punctated flaring rim elbow pipes; e, plain elbow pipe with distal stem end joined to the bowl. 


\section{LIST OF TABLES}

Table 1. Provenience of the Ceramic Vessels in the Boyce Smith Museum.

Table 2. Vessels from Red River County, Texas.

Table 3. Vessels from Bowie County, Texas.

Table 4. Vessels from Harrison County, Texas.

Table 5. Vessels from Marion County, Texas.

Table 6. Vessels from Camp County, Texas.

Table 7. Vessels from Upshur County, Texas.

Table 8. Vessels from Cherokee County, Texas.

Table 9. Vessels from Smith County, Texas.

Table 10. Vessels from Clark County, Arkansas.

Table 11. Vessels from miscellaneous contexts in Arkansas.

Table 12. Vessels from LeFlore County, Oklahoma.

Table 13. Identified ceramic types from the vessels from different counties in the Boyce Smith Museum.

Table 14. Use of tempers in the vessels in the Boyce Smith Museum.

Table 15. Firing conditions in the vessels in the Boyce Smith Museum. 


\section{INTRODUCTION}

The Boyce Smith Museum opened in 1968 with the purpose of displaying a large collection of Historic artifacts as well as Native American artifacts collected and/or purchased over the years by Mr. Boyce Smith of Troup, Texas, now deceased. After learning of the museum in 2002, and taking a short visit to the museum at that time, it was apparent that the Boyce Smith Museum contained an important collection of Native American ceramic vessels that warranted documentation. With the permission of Jo Beth Smith, the wife of Boyce Smith, and their son Rial Smith, we returned to the Boyce Smith Museum on December 10-11, 2007, to document 157 ceramic vessels from Caddo sites in eight counties in Northeastern Texas ( $\mathrm{n}=136)$, Caddo and Mississippian sites in five counties in southern Arkansas $(\mathrm{n}=20)$, and from the Spiro site in LeFlore County, in eastern Oklahoma ( $\mathrm{n}=1)$ (Figure 1 and Table 1). In almost all instances, the only available provenience information for the vessels in the Boyce Smith Museum is the state and county, although in a very few cases, a specific site and/or location within a county is included in Mr. Smith's collection notes.

Figure 1. Northeastern Texas, southern Arkansas, and eastern Oklahoma counties represented by ceramic vessels in the Boyce Smith Museum.

Table 1. Provenience of the Ceramic Vessels in the Boyce Smith Museum.

State County No. of Vessels

Jar $\quad \mathrm{BW} \quad \mathrm{CB} \quad \mathrm{CPB} \quad \mathrm{Bt}$ Other

Arkansas

Clark
Faulkner
Grant
Lee
Pike
Unknown

Oklahoma

LeFlore

Texas

$\begin{array}{lllllll}\text { Bowie } & - & 1 & 1 & - & 1 & - \\ \text { Camp } & 3 & - & 3 & 1 & - & - \\ \text { Cherokee } & 1 & 1 & 1 & - & - & 1^{* *} \\ \text { Harrison } & 5 & 1 & 5 & 1 & 6 & 1^{* *}\end{array}$


Table 1. Provenience of the Ceramic Vessels in the Boyce Smith Museum, cont.

\begin{tabular}{lllllllll}
\hline State & County & \multicolumn{7}{c}{ No. of Vessels } \\
& & Jar & BW & CB & CPB & Bt & Other \\
& & & & & & & \\
& Marion & 1 & - & 3 & - & 2 & $2^{* *}$ \\
& Red River & 46 & 14 & 11 & 2 & - & $2+$ \\
& Smith & 1 & 3 & 5 & - & 1 & - \\
& Upshur & 6 & 1 & 1 & 2 & - & - \\
& subtotal & 63 & 21 & 30 & 6 & 10 & 6 \\
& & & & & & & & \\
\end{tabular}

$\mathrm{BW}=$ bowl; $\mathrm{CB}=$ carinated bowl; $\mathrm{CPB}=$ compound bowl; $\mathrm{Bt}=$ bottle

*seed jar; **olla; + a canoe-shaped bowl and a beaker

It is our intent to make this information on the ceramic vessels from the Boyce Smith collections a part of the public record. We believe that there is important information to be gained as a result of this effort that will be of benefit in increasing knowledge of the archaeology of these regions of Texas, Arkansas, and Oklahoma. Private collections are very vulnerable to the possibility of being sold, or broken up, and there are few options for the holders of these collections to ensure that they remain together and also be available for future study. Because the publication of this documentation effort involves a sizable expense for report formatting and printing, and the funding for these publication efforts remain uncertain, we are publishing this report and accompanying figures and photographs on a $\mathrm{CD}$ for distribution to those primarily interested in Caddo archeology.

\section{METHODS OF VESSEL DOCUMENTATION}

For this ceramic vessel study, we established a documentation protocol to assist in the analysis of each of the vessels from the different counties in the Boyce Smith Museum. Each of the ceramic vessels is described and analyzed utilizing a consistent set of morphological, functional, and stylistic attributes modeled after the presentations in Cast et al. (2006); Gadus and Fields (1996); Gonzalez et al. (2005), Perttula et al. (1998, 2008), Perttula (2009), and Perttula (2005, ed.). The purpose of the documentation is to thoroughly characterize the character of each of the ceramic vessels in the collections. The sections that follow provide a summary of the completed vessel recordation forms from 14 counties in Northeastern Texas, southern Arkansas, and LeFlore County in eastern Oklahoma (see Figure 1), as well as selected vessel photographic illustrations.

The following attributes were employed in the ceramic vessel study:

Non-plastics: Deliberate and indeterminate materials in the paste (Rice 1987:411), including a variety of tempers (grog or crushed sherds, bone, hematite, shell, quartz 
sands, etc.) and "particulate matter of some size." The grog, bone, and hematite nonplastics appear to have been deliberately added to the paste as tempers. The bone used for temper had been burned and calcined, then crushed, before it was added to the paste.

Vessel Form: The principal vessel form categories include open containers (bowls, carinated bowls, and compound bowls) and restricted containers, including jars and bottles of several shapes and sizes. As restricted containers, jars allow access by hand, but bottles do not (Brown 1996:335). Another important vessel form, at least in burial contexts, is the effigy bowl with a modeled head (usually a bird or duck head) and a tab tail. Occasionally, an effigy vessel will have a broader tab tail that supported a anthropomorphic or zoomorphic tail rider (see Suhm and Jelks 1962:Plate 24k). There are also several vessels with legs or clay supports.

Additional form attributes that were recorded on each of the vessels (depending upon their completeness) include the rim profile (outflaring or everted, vertical or standing, and inverted), lip profile (rolled to the exterior, rounded, flat, or thinned), and base shape (flat or rounded).

Core Colors: Observations on ceramic cross-section colors permit consideration of oxidation patterns (Teltser 1993:Figure 2A-H; Perttula 2005, ed.), and thus the conditions under which the vessel was fired and then cooled after firing. Comments are included for these attributes on the presence and location of fire-clouding, sooting or smudging from cooking use (Skibo 1992), and the preservation and location of charred organic remains/residues.

Wall Thickness: Thickness was recorded in millimeters, using a vernier caliper, at the lip, along the rim, at several points along the body, and at the base when possible (only for the vessels that were not complete).

Interior and Exterior Surface Treatment: The primary methods of finishing the surface of the vessel include smoothing, burnishing, and polishing (Rice 1987:138). Brushing is a popular method of roughening the surface (particularly the body) of large and small Middle Caddo (ca. A.D. 1200-1400) and Late Caddo (ca. A.D. 1400-1680) period cooking jars and other utility wares over much of the Caddo area, but is here considered a decorative treatment rather than solely a functional surface treatment (cf. Rice 1987:138), although not all Caddo ceramic analysts treat brushing as a decorative treatment (cf. Gadus et al. 2006:31). In certain fine ware vessels, brushed bodies accompanied engraved rim panels. Smoothing creates "a finer and more regular surface... [and] has a matte rather than a lustrous finish" (Rice 1987:138). Burnishing, on the other hand, creates an irregular lustrous finish marked by parallel facets left by the burnishing tool (perhaps a pebble or bone). A polished surface treatment is marked by a uniform and highly lustrous surface finish, done when the vessel is dry, but without "the pronounced parallel facets produced by burnishing leather-hard clay" (Rice 1987:138).

The application of a hematite-rich clay slip (Ferring and Perttula 1987), either red or black after firing in an oxidizing or reducing (i.e., low-oxygen) environment, is 
another form of surface treatment noted in these vessel assemblages, albeit very rarely. The clay slip is more frequently applied on the vessel exterior than on the interior surface, and then was either burnished or polished after it was leather-hard or dry.

Height and Orifice Diameter: These attributes, measured in centimeters, were recorded with a ruler.

Diameter at Bottom of Rim and Base Diameter: Also recorded in millimeters using a ruler, these attributes permit characterization of the overall contour and shape of the vessel.

Volume: Vessel volume in liters was determined by filling (to within $1 \mathrm{~mm}$ of the lip) the vessel with lentil seeds, then dumping the lentil seeds in containers of known volume. In estimating the volume of vessels with holes, the vessel was first filled with a cloth that conformed to vessel contours, then the lentil seeds were poured into the depression in the cloth to within $1 \mathrm{~mm}$ of the top of the lip. Then they were dumped into containers of known volume. In cases where the vessels were not (or could not) be reconstructed, but measurements of height and orifice diameter were be obtained, volumes were estimated by comparison with known vessel volumes of specific forms (i.e., carinated bowl, jar, bottle, compound bowl, and bowl) in other documented Caddo vessel assemblages.

Decoration: Decorative techniques present in the vessel collections from counties in Northeastern Texas and Arkansas include engraving and excising, incising, punctating, pinching, stamping, lip notching, brushing, neck banding, and appliquéing, and on certain vessels, combinations of decorative techniques (i.e., brushed-punctated) created the decorative elements and motifs. Engraving and lip notching was done with a sharp tool when the vessel was either leather-hard, or after it was fired, while the other decorative techniques were executed with tools (stamping, incising, and punctation), by adding strips of clay to the wet body (appliqué), by crimping the coils (neck banding), using frayed sticks or grass stems (brushing) dragged across the body surface, or fingernails (certain forms of punctations and pinching), when the vessel was wet or still plastic. Excising is considered a form of engraved decoration, where the clay is deliberately and closely marked/scraped and carved away with a sharp tool, usually to create triangular elements (the pendant triangle or small tick marks) or crescent-shaped elements that separate or serve to define scrolls (Suhm and Jelks 1962:Plate 64a-b, f).

A red clay film or wash was added to the surface of some vessels as a slip before they were fired. Another form of vessel decoration is the use of red (hematite or ochre) or white (kaolin clay) clay pigments that have been smeared, impressed, or rubbed into the engraved lines of certain vessels.

Type: The kinds of named ceramic types in these collections follow primarily the work of Suhm and Jelks (1962), Thurmond (1990), Webb (1959), and Kleinschmidt (1982), as well as new types (Hood Engraved) and varieties of Poynor Engraved defined by Perttula (2008, 2009). 
In the sections that follow in this report, we first discuss the archeological character of the vessels found in the different counties represented in the collection. Then, this vessel data is employed to make regional and temporal comparisons of the kinds of decorative motifs and elements found on the different kinds of vessel forms, followed by assemblage-level considerations of vessel form, vessel size, use of temper, and firing conditions, as well as the use of pigments, from mortuary vessels of different ages and ceramic traditions in Northeastern Texas, southern Arkansas, and eastern Oklahoma (see Figure 1). 


\section{NORTHEASTERN TEXAS COUNTIES WITH VESSELS}

\section{Red River County}

More than $55 \%$ of the Caddo vessels $(n=75)$ from Northeast Texas in the Boyce Smith Museum are from Red River County. These include 46 jars (61\%), 14 bowls (19\%), 11 carinated bowls (15\%), two compound bowls (3\%), a beaker (1\%), and a canoe-shaped bowl (1\%) (Table 2). Conspicuous by their absence are bottles of any form. Many of the jars have four rim peaks, as well as a specific set of appliqued, punctated, and pinched decorative elements, and we have dubbed these Boyce appliqued-punctated vessels (see below) because they are especially abundant in the Boyce Smith Museum collections, and are not a form of decorated jar that we have encountered previously in Northeast Texas. It is unfortunate that there are no site-specific proveniences that can be associated with any of the Red River County vessels. The occasional occurrence of shelltempered Avery Engraved, grog-tempered Simms Engraved, and Nash Neck Banded vessels in the collections suggests that at least some of these vessels are from McCurtain phase contexts in the Red River basin in the northern part of the county (see Perttula 2008, ed.).

Two of the many jars from Red River County in the Boyce Smith Museum have a distinctive form, with tall and relatively narrow vessel bodies and wide, everted rims and rim peaks (Figure 2a-b); vessel volumes range from 1.25-1.3 liters (see Table 2). The first of these vessels is a Nash Neck Banded jar with six rows of neck banding on the rim, as well as four sets of three appliqued nodes under each rim peak (Figure 2a). The body has four vertical appliqued fillets (also under the rim peaks), four appliqued triangles and nodes pendant from the rim-body juncture, and three widely spaced rows of linear punctates that extend down the vessel body (Figure 2a). The second tall jar has four scalloped strap handles (Figure $2 b$ ). The rim has at least eight rows of pinching, and there is a tool punctated row at the rim-body juncture. There are also two widely spaced rows of linear punctates on the vessel body (Figure $2 b$ ).

Figure 2. Tall jars from Red River County: a, Nash Neck Banded (Vessel 63); b, Pinchedpunctated (Vessel 89).

One of the more distinctive vessel forms in the Red River County utility wares in the Boyce Smith Museum are the small (0.23-0.8 liters, see Table 2) jars with four rim peaks. Most of these are Boyce appliqued-punctated jars, but that label does not begin to capture the diversity in the decorative elements of these particular vessels. For example, one of the small rim peaked jars not included under the Boyce appliqued-punctated rubric has three rows of smoothed over neck banding on the rim, four sets of appliqued nodes under the rim peaks, and a circular punctated row at the rim-body juncture (Figure 3a). On the body are four triangular areas filled with pinching, and these are outlined by opposed diagonal rows of circular punctates. Vessel 122 has four rows of large circular punctates on the rim and four vertical sets of two appliqued nodes under each rim peak. There is a row of linear tool punctates at the rim-body juncture, and three rows of large circular punctates on the vessel body. 
Figure 3. Decorated jars with rim peaks from Red River County: a, neck bandedappliqued-punctated (Vessel 39); b, Boyce appliqued-punctated (Vessel 31); c, Boyce appliqued-punctated (Vessel 57); d, Boyce appliqued-punctated (Vessel 36); e, Boyce appliqued-punctated (Vessel 54); f, Boyce appliqued-punctated (Vessel 10); g, pinchedpunctated (Vessel 84); h, Boyce appliqued-punctated (Vessel 99); i, Boyce appliquedpunctated (Vessel 100); j, conjoined Boyce appliqued-punctated jars (Vessel 118).

The 20 Boyce appliqued-punctated jars (see Table 2) can be divided into four groups with respect to the decorative elements on the vessels. The largest group $(n=11)$ has pinched-punctated-appliqued decorative elements (see Figure 3b, d-g). The second group of vessels $(n=7)$ have broad grooved lines in addition to the pinched-punctatedappliqued elements 9see Figure 3c, i-j).

There are five vessels (Vessels 9, 10, 31, 33, and 81) in the first group with pinched rows on the rim, four sets of two appliqued nodes under the rim peaks, a row of punctations at the rim-body juncture, and two sets of either vertical appliqued fillets or two sets of a cluster of six appliqued nodes (see Figure 3b, f). Three others (Vessels 47, 54, and 96) have the same rim decoration as the aforementioned five Red River County vessels - pinched rows and four sets of appliqued nodes under the rim peaks (see Figure $3 \mathrm{e}$ ) - and have a row of punctations at the rim-body juncture, but the body decoration is distinctive. This consists of four triangular-shaped areas on the body filled with pinching that are separated from each other by diagonal arcs of punctations.

One vessel in the first group has pinched rows on the rim, four sets of appliqued nodes under the rim peaks, a row of circular punctations at the rim-body juncture, and a single row of deep and wide punctations on the upper vessel body (see Figure 3d). Another (Vessel 14), with strap handles, has rim pinching and two sets of appliqued nodes on the rim, and diagonal punctated lines on the body; between these diagonal punctated rows are four sets of appliqued nodes. A third vessel has a pinched rim, four sets of appliqued nodes, and two rows of small tool punctates on the vessel body (see Figure 3g).

In the second group of Boyce appliqued-punctated jars, one (Vessel 16) has pinched rows on the rim, as well as either two vertical sets of two appliqued nodes under two rim peaks or four vertical grooves under two rim peaks and through the pinching. On the body of this vessel, there are two sets of vertical grooved lines under the appliqued nodes on the rim, and clusters of appliqued nodes under the grooved lines on the rim. Another vessel (Vessel 119) has four sets of appliqued nodes under each rim peak, a horizontal grooved line at the rim-body juncture, as well as a row of small circular punctates within the grooved line. The other five vessels in this group (Vessels 3, 57, 100,118 , and 120) have between two to four rows of pinching on the rim, one to four sets of appliqued nodes under the rim peaks, and a horizontal grooved line at the rim-body juncture that has a row or two of punctates in the grooved line (see Figure 3c, i-j). two conjoined jars (Vessel 118) also have four vertical grooved lines on the rim (see Figure $3 \mathrm{j}$ ). Body decorations range from triangular areas filled with punctations (Vessels 57 and 
118); punctated arcs (Vessel 100, see Figure 3i) below a single row of large tool punctates; a single row of large circular punctations (Vessel 120); to vertical appliqued fillets and clusters of six appliqued nodes (Vessel 3).

The third group of Boyce appliqued-punctated jars from Red River County has one vessel (Vessel 13). This jar has four rows of pinching on the rim, along with four vertical sets of appliqued nodes under each rim peak. On the vessel body are two opposed sets of vertical fillets or appliqué node clusters (with six nodes in three rows). The last group also has one vessel (Vessel 99). This jar has two rows of pinching on the rim and four vertical sets of two appliqued nodes under each rim peak (see Figure $3 \mathrm{~h}$ ). At the rimbody juncture is a horizontal incised band filled with two rows of circular punctations, and there is another row of deep tool punctations under the incised band. Finally, the lower part of the body has four sets of diagonal opposed tool punctated rows.

Other jars have a variety of decorative elements and combinations of decorative methods on rim and/or body. Jars with pinched decorations are common in the Red River County vessels (see Table 2). One very small jar has four rows of pinching on the rim and a single broad horizontal incised line at the rim-body juncture (Figure 4a). Two jars (Vessels 113 and 115) have pinched-incised-punctated rim and body decorations, starting with three or four rows of pinching on the rim and rows of punctations at the rim-body juncture (Figure 4c, f). They differ in that Vessel 12 has a single row of large circular punctations on the vessel body, while Vessel 115 has a closely-spaced series of near vertical to curvilinear incised lines and tool punctated rows on the body (Figure 4f) and Vessel 113 also has two sets of grooved vertical lines on the rim and triangular-shaped tool punctated areas on the body (Figure 4c).

Figure 4. Pinched and punctated jars from Red River County: a, pinched-incised (Vessel $15)$; b, pinched-punctated-grooved (Vessel 45); c, pinched-appliqued-punctated-grooved (Vessel 113); d, punctated (Vessel 61); e, punctated-incised-appliqued-grooved (Vessel 93); f, pinched-punctated-incised (Vessel 115).

There are other vessels with broad grooved or broad trailed lines on the Red River County jars. One has five rows of pinching on the rim, a broad horizontal grooved line at the rim-body juncture, and three rows of small circular punctations below the grooved line (see Figure 4b). Vessel 123 has a similar decoration to Vessel 115, with the exception that the tool punctated row at the rim-body juncture is in a broad horizontal grooved line. Related to these vessels is Vessel 94, with five rows of pinching on the rim, but with two broad horizontal grooved lines at and below the rim-body juncture, with three rows of small tool punctations between the two grooved lines. Two jars (Vessels 37 and 93) have two sets of three or four vertical grooved lines on the rim, amidst four rows of pinching. On Vessel 37, there are two sets of two appliqued nodes on the vessel body, along with three rows of small tool punctations. Vessel 93, on the other hand, has two alternating sets of punctated-appliqued elements or three vertical incised lines on the vessel body. The two punctated-appliqued sets consist of a large punctated triangle with a cluster of six appliqued nodes (in three rows) within the triangles (see Figure 4e). 
Two small to very small jars have incised-punctated decorations. One has a horizontal incised panel on the rim that has a single row of tool punctations within it (Vessel 74). The other, a Dunkin Incised jar (Vessel 44), has a cross-hatched incised rim, and a row of cane punctations in a horizontal incised panel at the rim-body juncture. There is a single row of large tool punctations on the vessel body.

Three of the small (0.58-0.65 liters) Red River County jars have strap handles. The rim and body surfaces of these vessels, including the handles, are completely covered with either pinched (Figure 5a) or fingernail punctated rows (Vessels 68 and 69). Another small jar (Vessel 79) has a single row of pinching on the rim, and the vessel also has three attached legs. Vessel 61 has five rows of large to small punctations on the rim, and a single row of large tool punctations on the vessel body (see Figure 4d).

Figure 5. Other decorated jars from Red River County: a, pinched (Vessel 112); b, punctated-appliqued-incised (Vessel 73); c, incised-appliqued-punctated (Vessel 85); d, incised-punctated-appliqued (Vessel 121).

Four jars have incised, punctated, and appliqued decorations on the rim and the body (see Figure 5b-d). Vessel 73 has three rows of tool punctations on the rim, as well as four sets of two appliqued nodes; the body is covered with panels of opposed diagonal incised lines (see Figure 5b). Two other vessels (Vessels 85 and 117) are much like the aforementioned Vessel 44 (Dunkin Incised) in that they have cross-hatched incised rims and a row of small cane or tool punctations at the rim-body juncture (see Figure 5c). Where they differ is in also having three vertical sets of three appliqued nodes on the upper vessel body. The last of the incised-punctated-appliqued vessels has closely-spaced vertical to curvilinear incised lines on the rim, a row of circular punctations at the rimbody juncture, and four vertical sets of three appliqued nodes on the vessel body (see Figure 5d).

Two jars (Vessels 48 and 124) have two or four loop handles. One of these (possibly an undefined variety of Nash Neck Banded) has partially smoothed neck banded coils on the rim as well as two sets of two appliqued nodes on the rim between each loop handle. The other, apparently shell-tempered and red-slipped (see Table 2), has two sets of three appliqued nodes in vertical rows on the vessel body. Vessel 66 has three smoothed over rows of neck banding or pinching, four appliqued nodes around the rim, and a row of circular punctations at the rim-body juncture, just above a broad shallow grooved or collared area.

One of the bowls from Red River County is a large red-slipped and shelltempered Late Caddo Avery Engraved deep bowl (Figure 6a). It has a motif repeated four times on the vessel that consists of two concentric semi-circles over an engraved triangle; each repetition of the motif is divided from the other by a vertical bracket with a backward S-shaped arc. 
Figure 6. Bowls from Red River County: a, Avery Engraved deep bowl (Vessel 127); b, incised bowl (Vessel 4); c, incised effigy bowl with tail rider (Vessel 82); d, incised bird effigy bowl (Vessel 42).

There are also four small bowls (0.1-0.4 liters) in the collection (see Table 2), each with simple decorations near the rim. One has a narrow horizontal incised band filled with vertical incised lines (see Figure 6b), and another (with two rim peaks has a single horizontal incised line above a zig zag incised line; the other side of the vessel has what appears to be a modeled face with eye and nose adornos (Vessel 11). The last two simple bowls are punctated: Vessel 83 has seven rows of large circular punctations on the body, and Vessel 75/86 has a single row of tool punctations on the rim, as well as faint horizontal brushing marks.

Three bowls from Red River County have bird effigy heads (see Figure 6c-d). Two of these have anthropomorphic tail riders (see Figure 6c) and the other has a large appliqued tab tail (see Figure 6d). While bird effigy vessels are common occurrences in post-ca. A.D. 1400 contexts in the upper Neches River basin (see Perttula 2009), Suhm and Jelks (1962:47 and Plate 24) note that they are found as funerary offerings as well in Late Caddo Texarkana and Titus phase burials. All three bird effigy vessels are decorated with three broad and widely-spaced horizontal incised lines on the upper part of the bowl. the bird effigies themselves have dots or drilled holes for eyes, and the bird effigies that are associated with the tail riders have distinctive scalloped heads and beaks (see Figure $6 c-d)$.

The Red River County vessels have an assortment of rare and unique vessel forms. Foremost among them is a canoe-shaped bowl with two prows (Figure 7c). This particular vessel, $23.0 \mathrm{~cm}$ in length and $5.5 \mathrm{~cm}$ in height, has 13 engraved pendant triangles on each side. Other canoe-shaped vessels have been reported from Titus and Frankston phase cemeteries that have been looted, and we are unaware of such a vessel being found on sites in either the Red River or lower Sulphur River basins in Northeast Texas,

Figure 7. Rattle bowls and canoe-shaped bowl from Red River County: a, incised rattle bowl (Vessel 90); b, pinched rattle bowl (Vessel 92); c, engraved canoe-shaped bowl (Vessel 80).

There also are two incised and or incised-pinched rattle bowls (Vessels 46 and 90) with four legs and ring bases (see Figure 7a). These rattle bowls, known from Belcher phase contexts in the Red River valley in southwestern Arkansas and northwestern Louisiana (see Suhm and Jelks 1962:Plate 26a, c) have concentric incised lines or pinched rows on the vessel, and two cross-hatched lines on the ends of each of the four large protruding knobs. The incised rattle bowl also has a single broad incised line that encircles the rim of the rattle bowl. Finally, there are four rattle bowls (see Table 2) with four legs and ring bases that are decorated on the bowl with three or four rows of pinching; the legs and ring bases are plain (see Figure 7b). There is also a single broad incised line on the flat bowl lip. Suhm and Jelks (1962:Plate 26h) illustrate a very similar 
rattle bowl form from the Belcher phase Foster site (3LA27) on the Red River in southwestern Arkansas.

The carinated bowls from Red River County are decorated with either engraved, engraved-punctated-appliqued, incised, or incised-punctated decorative elements (see Table 2). The one small incised-punctated vessel (Vessel 116, Figure 8a) had a decorative motif that resembles Pennington Punctated-Incised (see Suhm and Jelks 1962:Plate 61ab) in that it has six slanting bands of short parallel incised lines and slanting bands filled with tool punctations on the rim panel. Two other small carinated bowls classified as Davis Incised have five or six broad and overhanging horizontal incised lines on the rim (Figure 8b, see also Suhm and Jelks 1962:35 and Plate 18e).

Figure 8. Carinated bowls and compound bowl from Red River County: a, cf. Pennington Punctated-Incised (Vessel 116); b, Davis Incised (Vessel 95); c, engraved-appliqued carinated bowl (Vessel 98); d, Simms Engraved (Vessel 65); e, Simms Incised (Vessel 77); f, Simms Incised (Vessel 97); g, Simms Incised (Vessel 18); h, Avery Incised compound bowl (Vessel 60).

One carinated bowl, with four rim and lip adornos, has an engraved-punctatedappliqued decorative motif on the rim panel (see Figure 8c). The motif includes four sets of vertical cross-hatched brackets with a single curvilinear line on either side of the brackets, forming ovals; there are also curvilinear engraved lines on either side of the adornos where they extend onto the rim panel. There is a row of tool punctations at the vessel carination, as well as short segments of tool punctations on the upper part of the design, on either side of the brackets and ovals, but not above them on the rim (see Figure $8 \mathrm{c})$.

Six of the carinated bowls, all approximately the same size (0.49-0.64 liters) are Simms Engraved vessels ( $\mathrm{n}=3$ ) (see Figure $8 d$ ), or a related variety dubbed Simms Incised $(n=3)$; these latter have characteristic Simms Engraved decorative elements and motifs, except they are executed with incised lines, rather than post-fired engraved lines (see Figure 8e-g). The Simms Engraved vessels have four sets of engraved ovals (with an appliqued node placed at the center of the oval) with an upper row of pendant triangles (Vessel 40); or four repeated sets of designs on the narrow rim panel that are panel dividers comprised of a single short vertical line and three short curvilinear lines to either side (Vessels 52 and 65, see Figure 8d). Vessel 52 also has a row of small tool punctations below the carination.

One of the Simms Incised vessels has four sets of engraved ovals (with an appliqued node placed at the center of the oval) with an upper row of incised pendant triangles (Vessel 97, see Figure 8f). The other two (Vessels 18 and 77) have four repeated sets of incised designs on the narrow rim panel that consist of panel dividers comprised of a single short vertical line and two to four short curvilinear lines to either side (see Figure 8f-g). Vessel 18 also has an upper row of incised pendant triangles. 
The last of the carinated bowls (Vessel 76), a small vessel, has a single row of tool punctations on an exterior thickened rim.

One of the compound bowls, with large strap handles, has concentric semi-circles and near vertical ticked lines on the lower rim panel, reminiscent of Avery Engraved designs, but executed with incised lines (see Figure 8h). There is a single horizontal incised line on the upper rim panel.

Another unusual vessel in the Red River County collection is a large grogtempered beaker with incised, punctated, and pinched decorative elements (Vessel 91). There are two horizontal rows of pinching below the vessel lip, followed by a horizontal incised panel that consists of upper and low incised bands and a series of zig zag incised lines between the bands. Between each set of zig zag incised lines is a small punctated circle. The remainder of the beaker body has 11 horizontal rows of pinching.

\section{Bowie County}

There are three vessels from Bowie County in the Boyce Smith Museum (Table 3). Two are bowls or carinated bowls and the third is a bottle with a relatively straight neck. All three vessels have grog temper, but one of the carinated bowls - a globular form with two panels of decoration - is also tempered with crushed bone and grit (Figure $9 b)$.

Figure 9. Bowie County vessels: a, Hatchel Engraved bottle (Vessel 105); b, engraved bowl (Vessel 29); c, engraved-punctated carinated bowl (Vessel 128); d, sprocket lip on Vessel 128.

The Hatchel Engraved bottle (see Figure 9a), from a ca. A.D. 1400-1700 Texarkana phase occupation (Perttula 2005:Table 1), has both horizontal and semicircular ticked and non-ticked engraved lines on the vessel body, with the principal semicircular engraved element repeated four times around the vessel; these are divided by broad cross-hatched brackets. Within the principal semi-circular element is a central cross-hatched bracket and two sets of curvilinear ticked lines on either side of the bracket.

The medium-sized bowl (see Figure 9b) has two broadly-spaced horizontal engraved lines on the rim, and the body also has an engraved design. This consists of an engraved scroll with four embedded circles. The upper and lower scroll elements have repeating four triangular-shaped zones filled with a single nested oval.

The carinated bowl from Bowie County is a very large (4.9 liters) vessel with a distinctive Middle Caddo style sprocket lip (see Miller 1986) (see Figure 9c-d). The upper part of the rim panel has two widely-spaced horizontal engraved lines encircling the vessel, while the lower part of the rim panel has eight upper and lower engraved semi-circles on either side of a continuous punctated or dashed scroll line. 


\section{Harrison County}

The Boyce Smith Museum has 19 vessels identified in the inventory notes as coming from Harrison County (Table 4). Two of them (Vessel 156 and Vessel 171) are from the Patton site (41HS825), otherwise known as the Pea Patch site. This is a large Titus phase cemetery on the west side of Arms Creek, near Lake O' the Pines, with at least 88 burials believed to have been excavated there since the early 1960s (Perttula 2006:41-48).

The vessels from Harrison County include five engraved carinated bowls, one engraved compound bowl, five engraved bottles, an engraved deep bowl, and an engraved olla, all of types consistent with coming from Late Caddo Titus phase burials. There are also one plain bottle and five decorated jars (see Table 4). Represented fine ware types are Ripley Engraved, Wilder Engraved, Simms Engraved, and Taylor Engraved, and utility ware types from the Upshur County collection include Karnack Brushed-Incised, Harleton Appliqued, Pease Brushed-Incised, Maydelle Incised, and Cowhide Stamped; Cowhide Stamped is a northwestern Louisiana/southwestern Arkansas Belcher phase utility ware (Webb 1959). Two of the vessels appear to be shelltempered, including the Cowhide Stamped trade vessel, two have bone temper, one has crushed pieces of hematite and grog, and all the others have grog temper (see Table 4).

Four of the engraved carinated bowls, two small and two large in size, from Harrison County are classified as Ripley Engraved. They have different engraved motifs (see Thurmond 1990:Figure 6) repeated four or five times around the rim, including two with the scroll and circle with nested triangles (Figure 10b); an horizontal scroll (Vessel 167); and the pendant triangle motif (Figure 10a).

Figure 10. Carinated bowls, compound bowls, and deep bowls from Harrison County: a, Ripley Engraved (Vessel 162); b, Ripley Engraved (Vessel 168); c, Simms Engraved (Vessel 160); d, Ripley Engraved compound bowl (Vessel 166); e, horizontal engraved deep bowl (Vessel 163).

The other engraved carinated bowl is a grog-tempered Simms Engraved vessel with four panels on the rim (see Figure 10c). Each panel has a single centrally-placed horizontal engraved line, with vertical bracket dividers.

The one engraved compound bowl (see Figure10d) is a very large (6.5 liters) Ripley Engraved vessel. The upper rim panel has two widely-spaced horizontal lines on it, while the lower panel has a continuous scroll repeated four times around the rim. The deep bowl (see Figure 10e) resembles in form many examples of Avery Engraved vessels from the middle Red River region (see Suhm and Jelks 1962:Plate 2a-b, d, f, i), as well as Simms Engraved (see Suhm and Jelks 1962:Plate 71e), but is different from those defined Caddo ceramic types because it has only three widely-spaced horizontal engraved lines on the upper part of the vessel. 
The five engraved bottles have direct to flaring necks and globular bodies (Figure 11a-c), and range in height from 9.0-19.6 cm; volumes range from 0.17-0.54 liters. Two of the bottles are Wilder Engraved (Figure 11a) with interlocking circular scrolls and small central circles repeated four times around the vessel body. A third engraved bottle is a small Taylor Engraved vessel with hooked arm scrolls repeated four time on the body. A fourth bottle, of unidentified type, has a series of vertical and rectilinear scrolls on the vessel body (Figure 11b); a red pigment has been rubbed in the engraved lines. The last Harrison County bottle has four rectangular panels on the vessel body, and within each panel is a circle and cross engraved element (Figure 11c).

Figure 11. Bottles and ollas from Harrison County: a, Wilder Engraved (Vessel 158); b, engraved bottle with red pigment (Vessel 153); c, bottle with engraved circles and crosses (Vessel 114); d, Wilder Engraved olla (Vessel 161).

The large Wilder Engraved olla (see Figure 11d) has a vertical scroll motif with a small embedded circle. The motif is repeated four times around the vessel body. The large plain bottle ( 0.8 liters, see Table 4$)$ has a straight neck and a globular body.

There is a wide assortment of decorated jars in the Harrison County vessels, with one example of five different defined Caddo types. The first is a large Harleton Appliqued jar with a vertically brushed rim, three rows of tool punctations on the rim, and a brushed-appliqued body (Figure 12a). The appliqued motif on the body consists of a scroll and circle repeated four times around the vessel; each circle has a central appliqued node. Areas on the body between the appliqued strips have horizontal and overlapping brushing marks. The second utility ware jar is a large Pease Brushed-Incised vessel (Vessel 159) with a horizontally brushed rim, tool punctated rows pushed through the brushing on the rim, and six panels on the body defined by vertical punctated rows. Each panel has vertical brushed-incised lines and diagonal rows of tool punctates.

Figure 12. Decorated jars from Harrison County: a, Harleton Appliqued (Vessel 53); b, Karnack Brushed-Incised (Vessel 21); c, Maydelle Incised (Vessel 165); d, Cowhide Stamped (Vessel 171).

The large Karnack Brushed-Incised jar (see Figure 12b) has a short rim with three closely-spaced rows of tool punctations. The body is covered with horizontal to overlapping brushing marks. The very large (10.3 liters) Maydelle Incised jar has 12 sets of opposed incised lines on the rim (see Figure 12c). The shell-tempered Cowhide Stamped vessel is also large, with a short rim covered with a row of vertical stamped marks (see Figure 12d). The vessel body has scrolls with hooked arms that are outlined by incised lines, and the scroll bands are filled with transverse stamping marks. Virtually identical vessels have been recovered from Late Caddo Belcher phase contexts at the Belcher site in northwestern Louisiana (Webb 1959:Figure 109b, k). 


\section{Marion County}

The eight grog-tempered vessels from Marion County, probably from a site or sites in the vicinity of Lake O' the Pines, include three carinated bowls, two bottles, two ollas, and a large jar with strap handles (Table 5). All of the vessels are from late Titus phase contexts (ca. A.D. 1600), based on the identification of a Ripley Engraved vessel with a pendant triangle motif (cf. Thurmond 1990; Perttula 1992), and a Clements Brushed olla; although not common, these are found on $17^{\text {th }}$ century Caddo sites in the Big Cypress Creek drainage in Northeast Texas (Perttula 2005, ed.; Gonzalez et al. 2005).

The large to very carinated bowls from Marion County include two Ripley Engraved vessels and a third vessel - with an inverted rim - that has diagonal engraved zones (Figure 13a-c). One Ripley Engraved vessel has a pendant triangle motif (see Thurmond 1990:Figure 6a) repeated four times, with two oval (or peyote button-shaped) and two diamond-shaped central elements (Figure 13a), while the second has a continuous scroll (Figure 13b) motif repeated seven times around the vessel; the central scroll line has small triangular tick marks.

Figure 13. Engraved carinated bowls from Marion County: a, Ripley Engraved (Vessel 17); b, Ripley Engraved (Vessel 49); c, diagonal engraved zones (Vessel 19).

The inverted rim carinated bowl (see Figure 13c) resembles inverted rim engraved vessels from the Gum Creek Cluster of Titus phase sites in the Little Cypress Creek basin (Upshur County). These particular sites appear to have been occupied between ca. A.D. 1670-1720 (Perttula and Nelson 2007).

The other fine ware vessels from Marion County are two small to medium-sized bottles and a small Belcher Engraved olla (Figure 14a). The first bottle (Vessel 136) is a Bailey Engraved vessel with a late style spool neck; red pigment was rubbed in the engraved design. The second bottle (cf. Taylor Engraved) is a miniature form with a straight neck and a globular body. It has four engraved panels on the vessel body, each panel unique in execution and design, but the panels feature a hooked arm scroll and surrounding rectilinear interlocking engraved lines. A red clay pigment was also rubbed in the engraved lines.

Figure 14. Ollas from Marion County: a, Belcher Engraved miniature olla (Vessel 140); b, Clements Brushed (Vessel 138).

The small engraved olla (see Figure 14a), of the Belcher Engraved type, has circular engraved and dashed lines that are repeated four times around the vessel body. These elements are divided by triangular-shaped fill elements both above and below the central elements; the triangular-filled areas each have a single short dashed line within them. 
The other olla is a large Clements Brushed vessel (see Figure 14b). This has a short plain neck and a vertical brushed body. Ollas are rare in Titus phase contexts (see Perttula 2005, ed,:Table 11-10), comprising less than 1\% of a sample of more than 2030 documented Titus phase vessels in the Big Cypress Creek basin. They are found on sites in the eastern part of the Titus phase heartland in the Big Cypress Creek basin, particularly at sites like H. S. Taylor (41HS3), McKinney (41MR12), P. S. Cash (41CP2), Russell Bros. (41TT7), and J. M. Riley (41UR2) (see Thurmond 1990). Clements Brushed vessels are even rarer, with only two documented vessels from the Russell Bros. site in the large Big Cypress Creek Titus phase vessel database (see Perttula 2005, ed.:Table 11-10).

The one strap handled jar from Marion County is a large Harleton Appliqued vessel (Figure 15). This vessel is vertically brushed on the rim, and there are three rows of punctations on the rim: one under the lip, one midway down the rim, and the third at the rim-body juncture. The body of the jar has an appliqued diamond motif repeated four times around the vessel.

Figure 15. Harleton Appliqued jar from Marion County (Vessel 139).

\section{Camp County}

The seven vessels from Camp County in the Boyce Smith Museum include three large to very large carinated bowls, a very large compound bowl, and three large jars (Table 6). All are grog-tempered. The ceramic types represented in the collection of Camp County vessels indicate that they are from Late Caddo Titus phase (ca. A.D. 14301680) burials in the Big Cypress Creek basin of Northeast Texas (see Figure 1).

All three carinated bowls are the Ripley Engraved type (Figure 16a-b, d); one is red-slipped (Figure 16d), and two have either a red or white clay pigment rubbed in the engraved lines (see Table 6). Engraved motifs, always repeated four times, include the interlocking horizontal scroll (Figure 16b), the scroll (Figure 16a), and the circle and cross (Figure 16d). The very large Taylor Engraved compound bowl (Figure 16c) has a single horizontal engraved line on the upper rim panel and a hooked arm scroll motif repeated seven times on the lower rim panel. A white clay pigment has been uniformly rubbed in the engraved lines, but one area also has a red clay pigment.

Figure 16. Engraved fine ware vessels from Camp County: a, Ripley Engraved carinated bowl (Vessel 28); b, Ripley Engraved carinated bowl (Vessel 27); c, Taylor Engraved compound bowl (Vessel 24); d, Ripley Engraved carinated bowl (Vessel 20).

Two of the Camp County utility ware jars are Harleton Appliqued vessels (see Table 6). One jar with loop handles has a vertical brushed rim and an appliqued continuous scroll motif that is repeated four times around the vessel body (Figure 17a). The other Harleton Appliqued jar has four sets of appliqued lugs and nodes on the rim, which is otherwise plain. The body has four sets of appliqued chevrons divided by appliqued ovals and diamond elements. The third jar is a Maydelle Incised vessel (Figure 
17b). This vessel has diagonal and cross-hatched incised lines on the rim, a single row of tool punctations at the rim-body juncture, and closely-spaced vertical incised lines on the body that extend to near the vessel base.

Figure 17. Decorated utility wares from Camp County: a, Harleton Appliqued jar (Vessel 164); b, Maydelle Incised jar (Vessel 145).

\section{Upshur County}

There are 10 Caddo vessels from Upshur County in the Boyce Smith collections (Table 7). These include three engraved carinated bowls and compound bowls, a rattle bowl, and six jars, two with strap handles. The vessels are from Late Caddo Titus phase contexts, based on the identified types, among them Ripley Engraved, Taylor Engraved, Harleton Appliqued, Cass Appliqued, Pease Brushed-Incised, and Moore Noded.

The one carinated bowl is a very large Ripley Engraved carinated bowl with the pendant triangle motif (Figure 18a). Both compound bowls are very large (6.7 liters in volume) Taylor Engraved vessels. One has a plain upper panel, and the other has two widely-spaced horizontal engraved lines on the upper panel (Figure 18b). The lower panels on both compound vessels have horizontal hooked arm scrolls repeated four times around the panel, with vertical engraved brackets.

Figure 18. Engraved vessels from Upshur County: a, Ripley Engraved carinated bowl (Vessel 133); b, Taylor Engraved compound bowl (Vessel 144).

Another Upshur County vessel is a small Moore Noded bowl (Figure 19). It has four opposed large noded areas (i.e., the hollow rattle) with nine smaller nodes between each large nodes. Each of the large nodes has 12 smaller appliqued nodes on it.

Figure 19. Moore Noded rattle bowl from Upshur County, Vessel 151.

The six jars range from large to very large in size (1.2-3.4 liters in volume) (see Table 7). Two of them are Harleton Appliqued vessels with either four strap or loop handles (Figure 20a). The first vessel has vertical brushing on the rim, with rows of tool punctates under the lip and at the rim-body juncture; the strap handles are tool punctated. The body has two sets of appliqued ovals and two sets of interlocking appliqued strips. The other Harleton Appliqued jar (with rim peaks) has cross-hatched incised lines on the rim and linear tick marks under the lip; the loop handles have short vertical appliqued ridges (Figure 20a). On the vessel body, there is a horizontal appliqued fillet at the rimbody juncture as well as just above the base, and between these four sets of appliqued circles and vertical scrolls.

Figure 20. Decorated utility ware jars from Upshur County: a, Harleton Appliqued (Vessel 135); b, Pease Brushed-Incised (Vessel 130); c, Cass Appliqued (Vessel 142); d, Cass Appliqued (Vessel 131). 
The Pease Brushed-Incised jar (see Figure 20b) is horizontally brushed on the rim, and there is a single row of tool punctates at the rim-body juncture. The body is divided into four diagonal panels by diagonal appliqued fillets. Each panel is filled with diagonal brushing marks and a single diagonal row of tool punctates.

The three Cass Appliqued jars (see Figure 20c-d) are characterized by vertical appliqued ridges or fillets (32-58 separate appliqued strips) that extend from the rim-body juncture to the vessel base. Rim decoration on each Cass Appliqued jar is different: one has a plain rim (Vessel 132); a second has three widely-spaced rows of tool punctations (see Figure 20d); and the third has four rows of closely-spaced punctations (see Figure 20c).

\section{Cherokee County}

Three of the four Caddo vessels from Cherokee County (Table 8) are bonetempered, and the fourth has been tempered with grog. One of the vessels (Vessel 4) is listed in the inventory notes as having been found in the city of Maydelle, in the west central part of the county.

The grog-tempered vessel is a large Taylor Engraved olla or short-necked bottle with four sets of interlocking vertical scrolls (Figure 21c). Taylor Engraved, typically seen on post- $16^{\text {th }}$ century Caddo sites in the Big Cypress, upper Sabine, and Red River basins, has been found as a trade vessel on a few Late Caddo Frankston phase sites in the upper Neches River basin (Perttula 2008:Table 1).

Figure 21. Vessels from Cherokee County: a, opposed engraved carinated bowl (Vessel 182); b, interior engraved scalloped bowl, cf. Sanders Engraved (Vessel 4); c, Taylor Engraved olla or short-necked bottle (Vessel 189).

One of the bone-tempered vessels is a small jar (Vessel 183) with eight sets of short vertical pinched rows, four originating from the rim, and the other four originating near the base. The second bone-tempered vessel is a large globular carinated bowl with a plain upper panel and a lower rim panel with 17 sets of opposed engraved lines (see Figure 21a). The last bone-tempered vessel, found in Maydelle, is a large bowl with an interior thickened rim and a scalloped lip (see Figure 21b). This vessel has 70 nested hatched engraved triangles on the interior thickened portion of the rim. Brown (1996:404 and Figures 2-38e and 2-40) identifies such vessels as a late (ca. A.D. 1350-1450) style of Sanders Engraved, with interior rim decoration and scalloped lip. Related to these vessels are Middle Caddo period Spoonbill Engraved bowls from the upper Sabine River basin with upper and lower hatched triangles on the interior thickened rim (Perttula et al. 2007:Figures 11a-12).

\section{Smith County}

The 10 Smith County vessels in the Boyce Smith Museum (Table 9) are apparently from ca. A.D. 1480-1650 Frankston phase burials (see Perttula 2009:Table 6- 
37) in the upper Neches or upper Angelina river basins. This chronological estimate is based primarily on the dominance of Poynor Engraved, var. Hood vessels, regional var. $E$ of Poynor Engraved, and the occurrence of Hood Engraved effigy vessels.

Five of the Smith County vessels are engraved carinated bowls, including four small to very large globular vessels with Poynor Engraved, var. Hood rim decorations repeated between four and nine times on the rim panel (Figure 22a; see also Table 9). The fifth carinated bowl (Poynor Engraved, var. E, with an inverted rim, has a scroll and circle motif repeated four times around the vessel (Figure 22b)

Figure 22. Engraved fine ware vessels from Smith County: a, Poynor Engraved, var. Hood (Vessel 22); b, Poynor Engraved, var. E (Vessel 25); c, Hume Engraved bottle (Vessel 88); d, engraved jar or beaker (Vessel 5).

One Hume Engraved bottle, with a collared and straight neck (see Suhm and Jelks 1962:Plate 42a), is in the Smith County collection (see Figure 22c). It has four broad vertical cross-hatched panels on the vessel body. Hume Engraved bottles became an important part of upper Neches River fine ware vessel assemblages after ca. A.D. 1480 (see Perttula 2009:Table 6-37).

There is also a small engraved jar or beaker from Smith County (see Figure 22d and Table 9); it has two opposed sets of four suspension holes on the rim. This unique vessel form has nine rows of vertical cross-hatched pendant triangles on the rim, as well as two sets of concentric semi-circles on the Bessel body (see Figure 22d).

Two of the Smith County vessels are Hood Engraved effigy bowls; one (Hood Engraved, var. Hood) has a bird effigy head appendage and a tab tail (Figure 23a), while the other has opposed tabs (Figure 23b) rather than an effigy head. Both are decorated with horizontal engraved lines at the top of the rim, including three broadly-spaced engraved lines on one bowl (Figure 23a) and seven closely-spaced horizontal engraved lines on the other (Hood Engraved, var. unspecified).

Figure 23. Effigy bowls and rattle bowls from Smith County: a, Hood Engraved effigy bowl (Vessel 149); b, Hood Engraved effigy bowl (Vessel 125); c, incised four-legged rattle bowl (Vessel 51).

The last vessel in the Smith County collection is a rattle bowl with four legs that rest on a ring base (see Figure 23c); the body has four hollow knobs that protrude from the sides of the bowl. This vessel has broad concentric incised or grooved (cf. Suhm and Jelks 1962:51) semi-circles covering the upper vessel body, along with a broad incised line on the flat lip, and cross-hatched broad incised lines on the flat face of the hollow knobs. Suhm and Jelks (1962:Plate 26a, c) illustrate two virtually identical rattle bowls from Late Caddo Belcher phase contexts at sites along the Red River in southwestern Arkansas and northwestern Louisiana, and the Boyce Smith Museum has a similar rattle bowl from Red River County (see Figure 7a). If the provenience information on this Smith County vessel is accurate, we may conclude that this rattle bowl is clear evidence 
for the movement/trade of a specialized kind of vessel from Red River Caddos to an upper Neches River Caddo group.

\section{SOUTHERN ARKANSAS COUNTIES WITH VESSELS}

\section{Clark County}

There are 14 Caddo vessels in the Boyce Smith Museum from Clark County, Arkansas, in southwestern Arkansas (see Figure 1). This includes eight bottles, three carinated bowls, two jars, and a beaker or compound bowl (Table 10). Three of the vessels are more specifically identified in the inventory as coming from a site on Hollwood Creek (Vessels 146, 172, and 173). Based on the occurrence of both grog- and shell-tempered pottery vessels in the collection (with shell-tempered pottery becoming increasingly used for vessel manufacture after ca. A.D. 1400-1450, but during the midOuachita phase), and the range of decorations on the vessels, the Clark County vessels are from Mid-Ouachita phase (ca. A. D. 1300-1500) and Social Hill phase (ca. A.D. 1500-1650) burials.

All three of the carinated bowls are relatively small mid-Ouachita phase Friendship Engraved vessels (Figure 24a, c, d) with cross-hatched engraved zones and rectangular panels, as well as negative scrolls. One of the vessels also has a distinctive sprocket lip (Figure 24b) (Miller 1986), a form of lip treatment most frequently seen in Caddo fine ware vessels in the mid-Ouachita basin. The sprocket-lipped vessel has a central oval and small circle element, with spurs or rays, that is repeated four times around the vessel rim (Figure 24a).

Figure 24. Engraved carinated bowls and beaker/compound bowl from Clark County, Arkansas: a, Friendship Engraved (Vessel 146); b, view of sprocket lip on Vessel 146; c, Friendship Engraved (Vessel 85); d, Friendship Engraved (Vessel 59); e, engraved beaker or compound bowl (Vessel 106).

The one beaker or compound bowl (see Figure 24e) is $16.4 \mathrm{~cm}$ tall, an has two opposed suspension holes under the vessel lip. The tall rim has three sets of intersecting diagonal engraved ladders, either filled with diagonal lines or small engraved rectangles, with a rayed circle between two sets of the engraved ladders. The vessel body has four sets of circles, and the innermost circle has four hatched pendant triangles (see Figure $24 \mathrm{e})$. Each of the sets of circles is separated from the other by vertical hatched brackets.

The engraved bottles from Clark County fall into two or three groups by form. Three (Vessels 6, 110, and 173) medium-sized bottles have straight necks and globular carinated bodies (Figure 25b-c); four others, also medium-sized, have straight necks and globular bodies (Figure 25a, d-e); and one post-A.D. 1500 bottle has a spool neck (Figure 25f).

Figure 25. Engraved bottles from Clark County, Arkansas: a, Friendship Engraved (Vessel 170); b, Means Engraved (Vessel 6); c, Belcher Engraved, var. Manchester 
(Vessel 173); d, Bottle with engraved panels (Vessel 34); e, Means Engraved? (Vessel 172); f, Hudson Engraved (Vessel 169).

With respect to the engraved decorations on the bottles, the spool-necked form is a shell-tempered Hudson Engraved vessel with red pigment rubbed in the engraved lines (see Figure 25f). The bottles with the carinated bodies include a Means Engraved vessel with four sets of concentric semi-circular ticked lines (see Figure 25b); a grog- and shelltempered Belcher Engraved, var. Manchester vessel (see Early 1993:86-87 and Figure 53c) with horizontal ticked and non-ticked lines on the upper vessel body and four lower sets of concentric circles (only one of which has ticks) (see Figure 25c); and an Adair Engraved, var. Adair vessel (see Brown 1996:377) with vertical appliqued ridges and narrow vertical cross-hatched bands (Vessel 110).

Among the four other bottles from Clark County is a small plain shell-tempered vessel (Vessel 87), and three engraved vessels. One of the engraved bottles is a Friendship Engraved vessel (see Figure 25a), with an upper set of short vertical and horizontal engraved lines repeated three times around the vessel, set above three semicircular bands divided into plain and cross-hatched segments, cross-hatched engraved brackets, and five short vertical engraved lines within a space below each of the semicircular bands. The second (see Figure 25d) has three large oval-shaped body panels defined by two or three engraved lines, and divided by a vertical panel of circles and a single vertical scroll line. Within each of the large oval-shaped body panels is a single centrally-placed hooked arm scroll. The last of the Clark County engraved bottles, possibly a variety of Means Engraved because of the sets of ticked horizontal lines under the bottle neck (see Figure 25e), has a ticked scroll and circle motif with cross-hatched scroll filler elements.

The two jars are both medium-sized (1.2-1.3 liters in volume) grog-tempered Military Road Incised vessels (Figure 26). Both have horizontal incised scrolls (with from 3-5 lines per scroll) on the rim and vessel body, with short vertical, horizontal, or diagonal incised line filler elements on either side of the rim and body scrolls.

Figure 26. Military Road Incised vessel from Clark County, Arkansas (Vessel 62).

\section{Pike County}

Pike County is in the Little Missouri River basin in southwestern Arkansas (see Figure 1). The one vessel from this county (Table 11) is listed in the Boyce Smith Museum inventory notes as coming from the Stokes Place (S1-A19-1), but no locational information is provided in the notes.

The vessel is a grog-tempered jar, probably Dunkin Incised, and may have come from a pre-A.D. 1300 Caddo burial possibly affiliated with the East phase (cf. Early 2002a). The jar has 11 closely-spaced horizontal incised lines on the rim and 12 vertical incised panels filled with diagonal incised lines pitched in opposite directions (Figure 27). 
Figure 27. cf. Dunkin Incised jar from Pike County, Arkansas (Vessel 107).

\section{Unknown County}

One vessel (not illustrated) is from an unknown county in Arkansas (see Table 11), but it is clearly of Caddo manufacture. It is an Adair Engraved, var. Neal bottle (see Brown 1996:377) with vertical appliqued fillets and vertical cross-hatched panels on the body. According to Brown (1996:377), this type and variety of bottle is found on Caddo sites in Garland, Clark, and Montgomery counties in Mid-Ouachita phase components (cf. Early 1993) in southwestern Arkansas in $14^{\text {th }}$ and $15^{\text {th }}$ century A.D. contexts.

\section{Southern Arkansas}

The vessel described in the Boyce Smith Museum notes as having a southern Arkansas provenience is a shell-tempered seed jar with an engraved-punctated decoration (Figure 28; see also Table 11). Shell-tempered seed jars with engraved decorations are common in ca. A. D. 1500-1650 Social Hill phase sites in the mid-Ouachita region of southwestern Arkansas (Early 1993:116-117, 2002b; see also Mainfort 2008).

Figure 28. Engraved-punctated seed jar from southern Arkansas (Vessel 157).

The seed jar has four repeating central engraved curvilinear and circular elements that are filled with punctations. Above and below this central element are a series of curvilinear hooked arm scrolls that are also repeated four times on the vessel body (see Figure 28).

\section{Faulkner County}

One vessel (not illustrated) in the Boyce Smith Museum is from Faulkner County in the Arkansas River basin in central Arkansas (see Figure 1). Its engraved design suggests it is of Caddo manufacture, probably from a Caddo potter living in the midOuachita region in southwestern Arkansas. This is a bottle with a straight neck and vertical engraved scrolls (see Table 11). The scrolls, comprised of four sets of closelyspaced engraved lines that end in hooked arms, are repeated eight times around the vessel body. There are horizontal engraved lines used as fillers on the body between the vertical scrolls.

\section{Lee County}

Lee County, Arkansas, is in the Mississippi River basin, in eastern Arkansas (see Figure 1). The plain shell-tempered bottle from the county has a broad globular body and a straight to flaring neck (Figure 29a; see also Table 11). In form, it closely resembles plain bottles found in late Mississippian to early historic sites in the region (cf. Ford 1961:Figures 16a, 18n-r, and 20o-p; House 1991:Figure 3e). 
Figure 29. Vessels from Lee and Grant counties, Arkansas: a, plain bottle, Lee County (Vessel 103); b, Grant County engraved bottle (Vessel 129).

\section{Grant County}

The Grant County vessel is an engraved bottle with red pigment rubbed in the engraved lines (see Figure 29b; see also Table 11). Inventory notes indicate that the vessel is from the Pump site, in Redfield (which actually is in Jefferson County, in the Arkansas River basin). This vessel, probably a variety of Friendship Engraved, is of Caddo manufacture with horizontal engraved lines on the bottle neck, eight horizontal engraved lines on the upper vessel body, and a lower series of seven cross-hatched engraved ovals.

\section{EASTERN OKLAHOMA}

\section{Spiro Site, LeFlore County}

There is a single medium-sized engraved bottle in the collections that is identified as being from the famous Spiro site in LeFlore County, Oklahoma (see Figure 1). The bottle, with a straight neck and a rounded body (Figure 30), has three horizontal engraved lines below the bottle neck as well as two sets of pendant engraved circles and vertical hooked arm elements (Table 12). Although Brown (1996) does not discuss any vessels from the Spiro site that have these particular engraved elements, the bottle form is consistent with both plain and engraved vessels in the Spiro II through Spiro IV grave periods (ca. A.D. 1100-1450) (Brown 1996:Figures 1-48 and 1-51).

Figure 30. Engraved bottle from the Spiro site, LeFlore County, Oklahoma (Vessel 109).

\section{PIPES}

There are several different forms of clay pipes in the Boyce Smith Museum (Figure 31). Unfortunately, there is no provenience information available on any of them, but based on morphological and decorative elements, it is quite likely that the majority of them came from Caddo sites in the Big Cypress and upper Neches River stream basins.

Figure 31. Clay pipes in the Boyce Smith Museum: a, Red River long-stemmed pipe, variety Haley; b, L-shaped and rounded elbow pipes; c, Engraved and punctated elbow pipe; d, plain and engraved-punctated flaring rim elbow pipes; e, plain elbow pipe with distal stem end joined to the bowl.

The earliest of the clay pipes is a long-stemmed Red River pipe, variety Haley (see Figure 31a), found on Middle Caddo period (ca. A.D. 1200-1400) Caddo sites in Northeast Texas as well as along the Red River in northwestern Louisiana (Webb) and in the Ouachita River basin in southwestern Arkansas (Hoffman 1967:10). It has a relatively long but thick stem, with a large bowl, and a pointed distal projection. 
A second pipe is an plain L-shaped elbow pipe (see Figure 31b, left). This form appears to be the earliest kind of elbow pipe found in the upper Neches, Angelina, and middle Sabine River basins, dating from the ca. $14^{\text {th }}$ to early $15^{\text {th }}$ centuries A.D. (Rogers and Perttula 2004; Perttula 2009). The third pipe is a broad stemmed and plain elbow pipe with a gently rounded elbow (see Figure 31 b, right).

Three elbow pipes may have been found on upper Neches River basin Late Caddo sites (cf. Perttula 2009:6-136 to 6-145). The first of these pipes, with a distal stem knob, has sets of horizontal engraved lines around the straight stem and the bowl, as well as short engraved lines on the lower bowl; the engraved lines on the bowl rim and lower bowl comprise a narrow zone filled with a single row of small punctations (see Figure 31-c). This is a ca. A.D. 1400-1560 Var. B elbow pipe form (Perttula 2009:Figure 6-23). The second upper Neches style elbow pipe has a flaring bowl and a gently rounded elbow (see Figure 31d, left). It may be a Var. D elbow pipe (dating later than ca. A.D. 1560), although it is undecorated. The third elbow pipe has a wide flaring bowl, a distal stem knob, and a short stem (Var. C, ca. A.D. 1400-1650), with horizontal and vertical engraved lines on the bowl, and a series of small punctations on the distal stem knob (see Figure 31d, right).

The last elbow pipe, plain, has a short stem, a wide stem hole, and a short but wide bowl (see Figure 31e). On this pipe, the distal stem of the pipe has been turned up vertically and joined to the back side of the bowl. Such elbow pipes have been found on $16^{\text {th }}$ and $17^{\text {th }}$ century Caddo sites on the Red River (Hoffman 1967:10 and Figure 6b), the Little Missouri River area in southwestern Arkansas (Harrington 1920:Plate CIVa) as well as on Titus phase sites in the Big Cypress Creek drainage (Turner 1978:Figure 22d) and the late $17^{\text {th }}$ century Clements site in Cass County, Texas (Gonzalez et al. 2005:Figure 4-13). 


\section{REGIONAL AND TEMPORAL COMPARISONS}

Several different prehistoric Caddo ceramic traditions are represented in the vessels from the Boyce Smith Museum, as well as at least one vessel from Lee County belonging to an eastern Arkansas Late Mississippian period shell-tempered ceramic tradition. The different Caddo ceramic traditions can first be seen in the range of identified utility ware and fine ware ceramic types represented in the vessels from the different set of counties in Texas and Arkansas represented in the collections (Table 13). Although we would be in a better position to venture speculations about the temporal and cultural affiliations of the vessels by county if the site specific provenience of the vessels were known, but that is not the case. Nevertheless, groupings of Caddo vessels by specific counties (which overlap with specific river and creek drainages) nicely depict the stylistic and likely temporal differences and similarities between them in the kinds of decorated utility ware and fine ware vessels found in specific localities within the broader Caddo area (see Figure 1).

Table 13. Identified ceramic types from the vessels from different counties in the Boyce Smith Museum.

\begin{tabular}{|c|c|c|c|c|}
\hline \multirow[t]{2}{*}{ Type } & \multirow[b]{2}{*}{$\begin{array}{l}\text { Red- } \\
\text { Bowie }\end{array}$} & \multicolumn{2}{|l|}{ Texas } & \multirow{2}{*}{$\begin{array}{l}\text { Arkansas } \\
\text { Clark-Pike }\end{array}$} \\
\hline & & $\begin{array}{l}\text { Upshur-Camp- } \\
\text { Marion-Harrison }\end{array}$ & $\begin{array}{l}\text { Cherokee- } \\
\text { Smith }\end{array}$ & \\
\hline \multicolumn{5}{|l|}{ Utility Ware } \\
\hline $\begin{array}{l}\text { Boyce Appliqued- } \\
\text { Punctated* }\end{array}$ & $\mathrm{x}$ & & & \\
\hline Cass Appliqued & & $\mathrm{x}$ & & \\
\hline Clements Brushed & & $\mathrm{x}$ & & \\
\hline Cowhide Stamped & & $\mathrm{x}$ & & \\
\hline Davis Incised & $\mathrm{x}$ & & & \\
\hline Dunkin Incised & $\mathrm{x}$ & & & $\mathrm{x}$ \\
\hline Harleton Appliqued & & $\mathrm{x}$ & & \\
\hline \multicolumn{5}{|l|}{ Karnack Brushed- } \\
\hline Incised & & $\mathrm{x}$ & & \\
\hline Maydelle Incised & & $\mathrm{x}$ & & \\
\hline Military Road Incised & & & & $\mathrm{x}$ \\
\hline Moore Noded & & $\mathrm{x}$ & & \\
\hline Nash Neck Banded & $\mathrm{x}$ & & & \\
\hline Pease Brushed-Incised & & $\mathrm{x}$ & & \\
\hline $\begin{array}{l}\text { Pennington Punctated- } \\
\text { Incised }\end{array}$ & $\mathrm{x}$ & & & \\
\hline \multicolumn{5}{|l|}{ Fine Ware } \\
\hline Adair Engraved & & & & $\mathrm{x}$ \\
\hline Avery Engraved & $\mathrm{x}$ & & & \\
\hline Bailey Engraved & & $\mathrm{x}$ & & \\
\hline Belcher Engraved & & $\mathrm{x}$ & & $\mathrm{x}$ \\
\hline Friendship Engraved & & & & $\mathrm{x}$ \\
\hline Hatchel Engraved & $\mathrm{x}$ & & & \\
\hline Hood Engraved & & & $\mathrm{x}$ & \\
\hline
\end{tabular}


Table 13. Identified ceramic types from the vessels from different counties in the Boyce Smith Museum, cont.

\begin{tabular}{lllll}
\hline Type & & Texas & & Arkansas \\
& $\begin{array}{l}\text { Red- } \\
\text { Bowie }\end{array}$ & $\begin{array}{l}\text { Upshur-Camp- } \\
\text { Marion-Harrison }\end{array}$ & $\begin{array}{l}\text { Cherokee- } \\
\text { Smith }\end{array}$ & Clark-Pike \\
\hline $\begin{array}{l}\text { Hudson Engraved } \\
\text { Hume Engraved }\end{array}$ & & $\mathrm{x}$ & $\mathrm{x}$ \\
$\begin{array}{l}\text { Means Engraved } \\
\text { Poynor Engraved }\end{array}$ & & $\mathrm{x}$ & $\mathrm{x}$ \\
$\begin{array}{l}\text { Ripley Engraved } \\
\text { Sanders Engraved }\end{array}$ & $\mathrm{x}$ & $\mathrm{x}$ & $\mathrm{x}$ & \\
$\begin{array}{l}\text { Simms Engraved } \\
\text { Taylor Engraved }\end{array}$ & & $\mathrm{x}$ & $\mathrm{x}$ & \\
Wilder Engraved & & $\mathrm{x}$ & & \\
\hline
\end{tabular}

*provisional type; $\mathrm{x}=$ present

The Red-Bowie County vessels form a relatively consistent group of utility wares and fine wares that suggest most of the vessels from these counties are from the Red River valley, in the area between the mouth of the Kiamichi River downstream to the vicinity of Texarkana. The Davis Incised, Dunkin Incised, and Pennington PunctatedIncised utility ware vessels (see Table 13) in the collection indicate that some of the vessels are from pre-A.D. 1300 Caddo sites and burial features. The other utility ware vessels and the engraved fine wares are from early to late (ca. A.D. 1300-1700) Texarkana phase sites and burial features.

The Camp, Harrison, Marion, and Upshur County vessels are clearly from Late Caddo (ca. A.D. 1430-1680), Titus phase, sites in the Big Cypress Creek basin (see Perttula 2004:396-407, 2005, ed.:357-410). The range of ceramic types, as well as the different motifs on the principal fine ware (Ripley Engraved) suggest these vessels are from $16^{\text {th }}$ and $17^{\text {th }}$ century sites in the eastern ceramic tradition of the Titus phase. That tradition includes sites from the Prairie and Greasy Creek areas in Camp and Upshur counties and on Big Cypress Creek downstream to the Lake O' the Pines area in Marion and Harrison counties (Perttula 2005, ed.:404). Important eastern ceramic tradition pottery types include Ripley Engraved, Taylor Engraved, Simms Engraved, Bailey Engraved, proportionally more Harleton Appliqued (than in western ceramic tradition Titus phase sites), and Karnack Brushed-Incised (see Perttula 2005, ed.:404 and Table 11-10; see also Table 13). These eastern Titus phase Caddo sites also contain more trade ware vessels from Belcher phase Caddo groups that lived to the east along the Red River, such as Belcher Engraved, Cowhide Stamped, and Moore Noded (see Table 13).

In the Cherokee and Smith counties area of Northeast Texas, the identified fine ware vessels are - with one exception - from Late Caddo Frankston phase (ca. A.D. 1400-1650) sites in the upper and middle reaches of the Neches and Angelina river basins. That one exception is an apparent interior rim decorated Sanders Engraved vessel 
of Middle Caddo period age (ca. A.D. 1200-1400) from a site found in the area of Maydelle, Texas (see Table 13). Otherwise, the fine wares from these two counties are completely consistent with the vessels coming from sites and burial features of likely post-A.D. 1480 contexts (Perttula 2009:Table 6-37), based on the frequency of Poynor Engraved, var. Hood vessels, the Hume Engraved bottle, and a Taylor Engraved vessel (see Table 13).

Finally, the vessels in the Boyce Smith Museum from Clark and Pike counties in Southwest Arkansas (see Table 13) are from aboriginal Caddo sites and burial features in the Ouachita River basin. These sites and burial features represent two periods of settlement by Caddo peoples, one that took place between ca. A.D. 1250-1500 (Adair Engraved, Friendship Engraved, Means Engraved, Dunkin Incised, and Military Road Incised) and the other between ca. A.D. 1500-1650 (Belcher Engraved and Hudson Engraved) (Early 1993, 2002a, 2002b).

That these groupings of vessels from the Boyce Smith Museum by county represent to some significant respect samples of vessels from different aboriginal Caddo ceramic traditions in Northeast Texas and Southwest Arkansas is also apparent on technological grounds. Although the ceramics from each of these areas are predominantly grog-tempered (between $76.9-90.7 \%$ of the vessels from the different areas have grog temper, either as the sole aplastic, or in combination with bone, hematite, grit, or shell), the vessels from each group of counties are different in regard to certain temper combinations and preferences, as well as with respect to temper-paste combinations (Table 14).

Table 14. Use of tempers in the vessels in the Boyce Smith Museum.

\begin{tabular}{|c|c|c|c|c|}
\hline \multirow{2}{*}{$\begin{array}{l}\text { Temper } \\
\text { and paste }\end{array}$} & \multirow[b]{2}{*}{$\begin{array}{l}\text { Red- } \\
\text { Bowie }\end{array}$} & \multicolumn{2}{|l|}{ Texas } & \multirow{2}{*}{$\begin{array}{l}\text { Arkansas } \\
\text { Clark-Pike }\end{array}$} \\
\hline & & $\begin{array}{l}\text { Upshur-Camp- } \\
\text { Marion-Harrison }\end{array}$ & $\begin{array}{l}\text { Cherokee- } \\
\text { Smith }\end{array}$ & \\
\hline grog & $22.9 *$ & 81.4 & 57.1 & 69.2 \\
\hline grog-sandy paste & 12.9 & 2.3 & - & - \\
\hline grog-shell & - & - & - & 7.7 \\
\hline $\begin{array}{l}\text { grog-bone } \\
\text { grog-bone-sandy }\end{array}$ & 28.6 & 4.7 & - & - \\
\hline paste & 10.0 & - & - & - \\
\hline grog-bone-grit & 2.9 & - & - & - \\
\hline grog-hematite & 1.4 & 2.3 & 21.4 & - \\
\hline $\begin{array}{l}\text { grog-hematite-bone } \\
\text { grog-hematite-sandy }\end{array}$ & 1.4 & - & - & - \\
\hline paste & 1.4 & - & - & - \\
\hline grog-grit & 2.9 & - & - & - \\
\hline grog-grit-sandy paste & 1.4 & - & - & - \\
\hline shell & 2.9 & 4.7 & - & 23.1 \\
\hline bone & 8.6 & 4.7 & 21.4 & - \\
\hline sandy paste only & 2.9 & - & - & - \\
\hline
\end{tabular}


Table 14. Use of tempers in the vessels in the Boyce Smith Museum, cont.

\begin{tabular}{|c|c|c|c|c|}
\hline \multirow{2}{*}{$\begin{array}{l}\text { Temper } \\
\text { and paste }\end{array}$} & \multicolumn{2}{|r|}{ Texas } & \multicolumn{2}{|r|}{ Arkansas } \\
\hline & $\begin{array}{l}\text { Red- } \\
\text { Bowie }\end{array}$ & $\begin{array}{l}\text { Upshur-Camp- } \\
\text { Marion-Harrison }\end{array}$ & $\begin{array}{l}\text { Cherokee- } \\
\text { Smith }\end{array}$ & Clark-Pike \\
\hline \multicolumn{5}{|c|}{$\begin{array}{l}\text { summary temper } \\
\text { findings**, vessels } \\
\text { with: }\end{array}$} \\
\hline grog & 85.7 & 90.7 & 78.6 & 76.9 \\
\hline bone & 51.4 & 9.3 & 21.4 & - \\
\hline hematite & 4.3 & 2.3 & 21.4 & - \\
\hline shell & 2.9 & 4.7 & - & 30.8 \\
\hline & 7.1 & - & - & - \\
\hline sandy paste & 28.6 & 2.3 & - & - \\
\hline Total vessels & 70 & 43 & 14 & 13 \\
\hline \multicolumn{5}{|c|}{$\begin{array}{l}\text { * percentage } \\
* * \text { summary values total to more than } ! 00 \% \text { because of the use of multiple tempers in single vessels, or } \\
\text { multiple tempers with a sandy paste clay, in many of the vessels }\end{array}$} \\
\hline \multicolumn{5}{|c|}{$\begin{array}{l}\text { Most Caddo potters in these areas preferred to use a fine grained clay, or a silty } \\
\text { clay, for vessel manufacture. However, a significant percentage of the vessels from Red } \\
\text { and Bowie counties have a sandy paste (see Table 14). Some potters in this area were } \\
\text { deliberately selecting a naturally occurring sandy clay for vessel manufacture, either } \\
\text { because it was locally abundant, or that sandy clay had certain favorable properties when } \\
\text { it came to the successful manufacture of durable and functionally serviceable vessels. } \\
\text { Vessels in the Red and Bowie counties area also contained significant quantities of } \\
\text { burned bone temper, as well as grit (or crushed rocks), while none of the vessels from the } \\
\text { other areas did (see Table 14). Hematite was a common temper additive only in the } \\
\text { Cherokee-Smith counties area, while mussel shell temper (seen usually in post } 15^{\text {th }} \\
\text { century contexts in these particular areas) is only abundant in the Clark County, Arkansas } \\
\text { vessels (see Table 14) in post-A.D. 1500 Social Hill phase contexts. The few instances of } \\
\text { shell-tempered vessels in the Red-Bowie and Camp-Harrison-Marion-Upshur county } \\
\text { groupings (see Table 14) represent trade vessels into Texarkana and Titus phase Caddo } \\
\text { communities that did not make shell-tempered pottery. }\end{array}$} \\
\hline
\end{tabular}

Information collected on the conditions in which these Caddo vessels were fired is also relevant to considerations of confirming that different Caddo ceramic traditions are represented in this set of Boyce Smith Museum vessels. In the case of the Red-Bowie, Titus phase, and Clark County, Arkansas, vessel groupings, the vast majority of the vessels in the collections have been fired in a low oxygen or reducing environment, probably having been smothered in a bed of hot coals and ashes (Table 15). Between 68$100 \%$ of the vessels from these areas have been fired in a reducing environment, compared to only $46.2 \%$ in the Frankston phase vessels from Cherokee and Smith 
counties (Table 15). Instead, the Frankston phase vessels have been fired more frequently in a high oxygen or oxidizing environment (53.8\%), a firing where the vessel is continually exposed to the air during the entire firing process; vessels fired this way tend to be yellow, red, and reddish-brown in color, despite the clays that were selected for vessel manufacture. Vessels fired in a reducing environment tend to have dark brown, gray, to black vessel surfaces.

Table 15. Firing conditions in the vessels in the Boyce Smith Museum.

\begin{tabular}{|c|c|c|c|c|}
\hline \multirow{2}{*}{$\begin{array}{l}\text { Firing } \\
\text { conditions }\end{array}$} & \multicolumn{3}{|c|}{ Texas } & \multirow{2}{*}{$\begin{array}{l}\text { Arkansas } \\
\text { Clark-Pike }\end{array}$} \\
\hline & $\begin{array}{l}\text { Red- } \\
\text { Bowie }\end{array}$ & $\begin{array}{l}\text { Upshur-Camp- } \\
\text { Marion-Harrison }\end{array}$ & $\begin{array}{l}\text { Cherokee- } \\
\text { Smith }\end{array}$ & \\
\hline Oxidizing environment & $32.0^{*}$ & 16.7 & 53.8 & - \\
\hline Reducing environment & 34.7 & 38.1 & 30.8 & 80.0 \\
\hline $\begin{array}{l}\text { Reducing environment, } \\
\text { but cooled in a } \\
\text { low oxygen } \\
\text { environment }\end{array}$ & 33.3 & 45.2 & 15.4 & 20.0 \\
\hline Total no. of vessels & 75 & 42 & 13 & 15 \\
\hline \multicolumn{5}{|l|}{ *percentage } \\
\hline \multicolumn{5}{|c|}{$\begin{array}{l}\text { Even in the areas where the Caddo potters preferred to fire their vessels in a } \\
\text { reducing environment, there are further differences that warrant mention. In the Red- } \\
\text { Bowie and Titus phase areas in Northeast Texas, about } 50 \% \text { of the reduced firing vessels } \\
\text { were subsequently pulled from the fire and allowed to cool in the open air (see Table 15); } \\
\text { this led to vessels with thin oxidized (or lighter-colored) surfaces on either one or both } \\
\text { vessel surfaces, but left much of the vessel core dark brown, dark gray, or black in color. } \\
\text { Only } 20-33 \% \text { of the vessels from Clark-Pike counties, Arkansas, or Cherokee-Smith } \\
\text { counties, Texas were cooled in this manner (see Table 15). }\end{array}$} \\
\hline
\end{tabular}




\section{SUMMARY AND CONCLUSIONS}

The Boyce Smith Museum in Troup, Texas, has 157 aboriginal ceramic vessels from sites (and burials) in a number of counties in Northeast Texas, southern Arkansas, and eastern Oklahoma (see Figure 1). We make the assumption that whole vessels (especially whole vessels that have not been reconstructed) on Caddo sites must have come from burial features, whereby whole vessels were left as funerary offerings with the deceased Caddo individual.

Provenience of the vessels from other than a county level is sadly lacking, however, which limits the research utility of the collection to a certain extent. Nevertheless, because of the generally well understood nature of Caddo vessel forms, decoration, and technology, it has been possible to discern groupings of these vessels in the collections by counties that represent a number of temporally and culturally distinctive Caddo ceramic traditions.

These ceramic traditions are best represented by $16^{\text {th }}$ and $17^{\text {th }}$ century Titus phase fine wares and utility wares from sites and burial features in the Big Cypress Creek basin (Camp, Harrison, Marion, and Upshur counties), Mid-Ouachita (ca. A.D. 1250-1500) and Social Hill (ca. A.D. 1500-1650) phase sites and burial features in the Ouachita River basin in Southwest Arkansas (Clark and Pike counties), and Frankston phase (ca. A.D. 1400-1650) sites and burial features in the upper Neches and Angelina River basins. The Red-Bowie counties grouping of vessels is more eclectic (in part because of the occurrence of a number of distinctive pinched-punctated-appliqued Boyce AppliquedPunctated jars), and a specific geographical area of origin for the vessels as a group can only plausibly be suggested to be in the Red River drainage basin in the Texarkana phase area. The vessels from those two counties include examples that suggest they derive from both pre-A.D. 1300 and ca. A.D. 1300-1700 sites and burial features. 


\section{REFERENCES CITED}

Brown, James A.

1996 The Spiro Ceremonial Center: The Archaeology of Arkansas Valley Caddoan Culture in Eastern Oklahoma. 2 Vols. Memoirs No. 29. Museum of Anthropology, University of Michigan, Ann Arbor.

Cast, Robert, Timothy K. Perttula, Bobby Gonzalez, and Bo Nelson

2006 Documentation of Caddo Ceramic Vessels from 41WD60, Wood County, Texas. Historic Preservation Program, Caddo Nation of Oklahoma, Binger, Oklahoma.

Early, Ann M.

2002a The East Phase. Field Notes 304:4-8. Newsletter of the Arkansas Archeological Society, Fayetteville.

2002b The Social Hill Phase. Field Notes 306:10-13. Newsletter of the Arkansas Archeological Society, Fayetteville.

Early, Ann M. (editor)

1993 Caddoan Saltmakers in the Ouachita Valley: The Hardman Site. Research Series No. 42. Arkansas Archeological Survey, Fayetteville.

Ferring. C. Reid and Timothy K. Perttula

1987 Defining the Provenance of Red-Slipped Pottery from Texas and Oklahoma by Petrographic Methods. Journal of Archaeological Science 14:437-456.

Ford, James E.

1961 Menard Site: The Quapaw Village of Osotouy on the Arkansas River. Anthropological Papers, Volume 48, Part 2. American Museum of Natural History, New York.

Gadus, Eloise F. and Ross C. Fields

1996 Ceramic Vessels from the Pleasure Point Site (41MR63), Marion County, Texas. Technical Report No. 22. Prewitt and Associates, Inc., Austin.

Gadus, Eloise F., Ross C. Fields, Jennifer K. McWilliams, John Dockall, and Michael C. Wilder

2006 National Register Testing of Seven Prehistoric Sites in the Sabine Mine's Area Q, Harrison County, Texas. Reports of Investigations No. 147. Prewitt \& Associates, Inc., Austin.

Gonzalez, Bobby, Robert Cast, Timothy K. Perttula, and Bo Nelson

2005 A Rediscovering of Caddo Heritage: The W. T. Scott Collection at the American Museum of Natural History and Other Caddo Collections from Arkansas and Louisiana. Historic Preservation Program, Caddo Nation of Oklahoma, Binger, Oklahoma. 
Harrington, Mark R.

1920 Certain Caddo Sites in Arkansas. Indian Notes and Monographs, Miscellaneous 10. Museum of the American Indian, Heye Foundation, New York.

Hoffman, Michael P.

1967 Ceramic Pipe Style Chronology along the Red River Drainage in Southwestern Arkansas. The Arkansas Archeologist 8(1):4-14.

House, John H.

1991 The Mississippian Sequence in the Menard Locality, Eastern Arkansas. In Arkansas before the Americans, edited by Hester A. Davis, pp. 6-39. Research Series No. 40. Arkansas Archeological Survey, Fayetteville.

Kleinschmidt, Ulrich K. W.

1982 Review and Analysis of the A. C. Saunders Site, 41AN19, Anderson County, Texas. Master's thesis, Department of Anthropology, The University of Texas at Austin.

Mainfort, Robert C., Jr.

2008 Sam Dellinger: Raiders of the Lost Arkansas. University of Arkansas Press, Fayetteville.

Miller, John E., III

1986 The Myers Mound: Salvage Excavations at a Caddo II Site in Southwest Arkansas. The Arkansas Archeologist 23/24:67-127.

Perttula, Timothy K.

1992 "The Caddo Nation": Archaeological \& Ethnohistoric Perspectives. University of Texas Press, Austin.

2004 The Prehistoric and Caddoan Archeology of the Northeastern Texas Pineywoods. In The Prehistory of Texas, edited by Timothy K. Perttula, pp. 370-407.

2005 1938-1939 WPA Excavations at the Hatchel Site (41BW3) on the Red River in Bowie County, Texas. Southeastern Archaeology 24(2):180-198.

2006 A Study of the Buddy Calvin Jones Collection from Northeast Texas Caddo Sites. Special Publication No. 6. Friends of Northeast Texas Archaeology, Pittsburg and Austin.

2008 Trends and Varieties in Late Caddo and Historic Caddo Fine Ware Pottery Types in the Upper Neches River Basin. Journal of Northeast Texas Archaeology 28:5155 . 
2009 The Ceramic Artifacts from the Lang Pasture Site (41AN38) and the Place of the Site within an Upper Neches River Basin Caddo Ceramic Tradition. In Archeological Investigations at the Lang Pasture Site (41AN38) in the Upper Neches River Basin of East Texas, assembled and edited by Timothy K. Perttula and David B. Kelley. Coastal Environments, Inc., Baton Rouge.

Perttula, Timothy K. (editor)

2005 Archeological Investigations at the Pilgrim's Pride Site (41CP304), a Titus Phase Community in the Big Cypress Creek Basin, Camp County, Texas. 2 Vols. Report of Investigations No. 30. Archeological \& Environmental Consultants, LLC, Austin.

2008 The Archeology of the Roitsch Site (41RR16), an Early to Historic Caddo Village on the Red River in Northeast Texas. In Collected Papers from Past Texas Archeological Society Summer Field Schools, edited by Timothy K. Perttula, pp. 313-628. Special Publication No. 5. Texas Archeological Society, San Antonio.

Perttula, Timothy K. and Bo Nelson

2007 The Gum Creek Cluster: Protohistoric Caddo Sites in the Little Cypress Creek Basin, ca. 1670-1720. Journal of Northeast Texas Archaeology 26:128-135.

Perttula, Timothy K., Robert Cast, Bobby Gonzalez, and Bo Nelson 2008 Documentation of Unassociated and Culturally Unidentifiable Funerary Objects in the U.S. Army Corps of Engineers, Fort Worth District Collections Housed at the Texas Archeological Research Laboratory at The University of Texas at Austin. Historic Preservation Program, Caddo Nation of Oklahoma, Binger, Oklahoma.

Perttula, Timothy K., Mark Walters, Robert Cast, Bobby Gonzalez, and Bo Nelson 2007 Documentation of Funerary Offerings from a Prehistoric Caddo Burial at Site 41WD244, Wood County, Texas. Caddo Nation of Oklahoma and Archeological \& Environmental Consultants, LLC, Binger, Oklahoma, and Austin.

Perttula, Timothy K., Melinda Tate, Hector Neff, James W. Cogswell, Michael D. Glascock, Elizabeth Skokan, Susan Mulholland, Robert Rogers, and Bo Nelson

1998 Analysis of the Titus Phase Mortuary Assemblage at the Mockingbird Site (“Kahbakayammaahin"), 41TT550. Document No. 970849. PBS\&J, Austin.

Rice, Prudence M.

1987 Pottery Analysis: A Sourcebook. University of Chicago Press, Chicago.

Rogers, Robert and Timothy K. Perttula

2004 The Oak Hill Village (41RK214), Rusk County, Texas. Document No. 030083. PBS\&J, Austin. 
Skibo, James M.

1992 Pottery Function: A Use-Alteration Perspective. Plenum Press, New York.

Suhm, Dee Ann and Edward B. Jelks (editors)

1962 Handbook of Texas Archeology: Type Descriptions. Texas Archeological Society Special Publication 1 and Texas Memorial Museum Bulletin 4, The University of Texas at Austin.

Teltser, Patrice A.

1993 An Analytic Strategy for Studying Assemblage-Scale Ceramic Variation: A Case Study from Southeast Missouri. American Antiquity 58(3):530-543.

Thurmond, J. Peter

1990 Archeology of the Cypress Creek Drainage Basin, Northeastern Texas and Northwestern Louisiana. Studies in Archeology 5. Texas Archeological Research Laboratory, The University of Texas at Austin.

Turner, Robert L.

1978 The Tuck Carpenter Site and Its Relation to Other Sites within the Titus Focus. Bulletin of the Texas Archeological Society 49:1-110.

Webb, Clarence H.

1959 The Belcher Mound, A Stratified Caddoan Site in Caddo Parish, Louisiana. Memoirs No. 16. Society for American Archaeology, Salt Lake City. 
Table 2. Vessels from Red River County, Texas.

\begin{tabular}{|c|c|c|c|c|c|c|c|c|c|c|c|}
\hline Vessel No. & Temper & Vessel Form & $\begin{array}{l}\text { Rim- } \\
\text { Lip Form }\end{array}$ & $\begin{array}{l}\text { Firing } \\
\text { Cond. }\end{array}$ & $\begin{array}{l}\mathrm{Th} \\
(\mathrm{mm})\end{array}$ & ST & $\begin{array}{l}\text { Height } \\
(\mathrm{cm})\end{array}$ & $\begin{array}{l}\text { OD } \\
(\mathrm{cm})\end{array}$ & $\begin{array}{l}\mathrm{BD} \\
(\mathrm{cm})\end{array}$ & $\begin{array}{l}\text { Vol. } \\
\text { (liters) }\end{array}$ & Type/Decoration \\
\hline 3 & $?$ & Jar & EV-RO & $\mathrm{B}$ & 7.8 & $\begin{array}{l}\text { I SM/ } \\
\text { I OR }\end{array}$ & 7.4 & 9.2 & 4.0 & 0.42 & $\begin{array}{l}\text { appliqued-pinched-punctated } \\
\text { elements* }\end{array}$ \\
\hline 4 & $\begin{array}{l}\text { grog- } \\
\text { bone }\end{array}$ & Bowl & INV-RO & A & 8.5 & - & 3.8 & 7.0 & 4.8 & 0.1 & vertical incised ladder \\
\hline 9 & $\begin{array}{l}\text { grog- } \\
\text { bone/ } \\
\text { SP }\end{array}$ & Jar & D-RO & A & 8.2 & I/E SM & 6.2 & 9.0 & 4.5 & 0.23 & $\begin{array}{l}\text { appliqued-pinched-punctated } \\
\text { elements* }\end{array}$ \\
\hline 10 & $\begin{array}{l}\text { grog- } \\
\text { bone }\end{array}$ & Jar & $\mathrm{D}-\mathrm{RO}$ & A & 6.4 & I/E SM & 8.4 & 10.5 & 5.0 & 0.53 & $\begin{array}{l}\text { appliqued-pinched-punctated } \\
\text { elements* }\end{array}$ \\
\hline 11 & $\begin{array}{l}\text { grog- } \\
\text { bone/ } \\
\text { SP }\end{array}$ & Bowl & D-RO & G & 10.9 & - & 5.2 & 9.1 & 4.8 & 0.19 & zig-zag incised; modeled face \\
\hline 12 & $\begin{array}{l}\text { grog/ } \\
\text { SP }\end{array}$ & Jar & EV-RO & $\mathrm{F}$ & 7.8 & I/E SM & 8.8 & 11.2 & 5.0 & 0.59 & $\begin{array}{l}\text { pinched-punctated-incised } \\
\text { elements }\end{array}$ \\
\hline 13 & $\begin{array}{l}\text { grog- } \\
\text { bone }\end{array}$ & Jar & EV-RO & A & 7.3 & I SM & 7.0 & 10.5 & 5.0 & 0.44 & punctated-appliqued elements \\
\hline 14 & bone & $\begin{array}{l}\text { Jar with } 4 \\
\text { strap handles }\end{array}$ & EV-RO & A & 7.6 & I SM & 5.0 & 10.6 & 5.5 & 0.32 & $\begin{array}{l}\text { pinched-punctated-appliqued } \\
\text { elements* }\end{array}$ \\
\hline 15 & $\begin{array}{l}\text { bone- } \\
\text { grog/ } \\
\text { SP }\end{array}$ & Jar & D-RO & $\mathrm{B}$ & 8.1 & - & 5.8 & 8.0 & 5.0 & 0.28 & $\begin{array}{l}\text { pinched-incised elements; } \\
\text { lip notched }\end{array}$ \\
\hline 16 & $\begin{array}{l}\text { grog- } \\
\text { hematite/ } \\
\text { SP }\end{array}$ & Jar & EV-RO & $\mathrm{F}$ & 8.8 & $\mathrm{I} / \mathrm{E} \mathrm{SM}$ & 7.0 & 11.0 & 5.0 & 0.46 & $\begin{array}{l}\text { pinched-appliqued-grooved } \\
\text { elements* }\end{array}$ \\
\hline 18 & $?$ & $\mathrm{CB}$ & D-FL & A & 7.1 & $\begin{array}{l}\text { I SM/ } \\
\text { E B }\end{array}$ & 6.5 & 16.3 & 7.0 & 0.64 & Simms Engraved (but incised) \\
\hline 31 & $\begin{array}{l}\text { grog- } \\
\text { hematite }\end{array}$ & Jar & EV-RO & G & 8.3 & $\begin{array}{l}\text { I SM/ } \\
\text { E B }\end{array}$ & 6.5 & 9.8 & 4.5 & 0.38 & $\begin{array}{l}\text { pinched-punctated-appliqued } \\
\text { elements* }\end{array}$ \\
\hline 33 & $?$ & Jar & $\mathrm{D}-\mathrm{RO}$ & $\mathrm{B}$ & 6.9 & I SM & 7.5 & 11.0 & 4.5 & 0.5 & $\begin{array}{l}\text { pinched-punctated-appliqued } \\
\text { elements* }\end{array}$ \\
\hline
\end{tabular}


Table 2. Vessels from Red River County, Texas, cont.

\begin{tabular}{|c|c|c|c|c|c|c|c|c|c|c|c|}
\hline Vessel No. & Temper & Vessel Form & $\begin{array}{l}\text { Rim- } \\
\text { Lip Form }\end{array}$ & $\begin{array}{l}\text { Firing } \\
\text { Cond. }\end{array}$ & $\begin{array}{l}\text { Th } \\
(\mathrm{mm})\end{array}$ & ST & $\begin{array}{l}\text { Height } \\
(\mathrm{cm})\end{array}$ & $\begin{array}{l}\mathrm{OD} \\
(\mathrm{cm})\end{array}$ & $\begin{array}{l}\mathrm{BD} \\
(\mathrm{cm})\end{array}$ & $\begin{array}{l}\text { Vol. } \\
\text { (liters) }\end{array}$ & Type/Decoration \\
\hline 36 & $\begin{array}{l}\text { grog- } \\
\text { bone }\end{array}$ & Jar & $\mathrm{D}-\mathrm{RO}$ & $\mathrm{F}$ & 7.4 & $\mathrm{I} / \mathrm{E} \mathrm{SM}$ & 8.0 & 10.8 & 4.5 & 0.52 & $\begin{array}{l}\text { appliqued-punctated-pinched } \\
\text { elements* }\end{array}$ \\
\hline 37 & $\begin{array}{l}\text { grog- } \\
\text { bone }\end{array}$ & Jar & D-FL & A & 7.3 & I/E SM & 8.0 & 8.7 & 4.5 & 0.42 & $\begin{array}{l}\text { appliqued-pinched-punctated } \\
\text { elements* }\end{array}$ \\
\hline 38 & grog & $\mathrm{CB}$ & D-FL & $\mathrm{F}$ & 9.3 & - & 7.0 & 17.5 & 10.0 & 0.74 & Davis Incised \\
\hline 39 & $\begin{array}{l}\text { grog/ } \\
\text { SP }\end{array}$ & Jar & EV-RO & G & 8.0 & I/E SM & 9.0 & 11.5 & 6.0 & 0.62 & Neck banded and appliqued \\
\hline 40 & SP & $\mathrm{CB}$ & INV-FL & A & 9.0 & I/E SM & 6.5 & 16.0 & 8.1 & 0.62 & Simms Engraved \\
\hline 42 & $\begin{array}{l}\text { grog- } \\
\text { bone }\end{array}$ & Effigy bowl & D-FL & $\mathrm{H}$ & 11.3 & - & 8.0 & 11.0 & 5.5 & 0.35 & Horizontal incised lines \\
\hline 44 & grog & Jar & EV-RO & G & 9.5 & I SM & 9.5 & 12.0 & 5.5 & 0.68 & $\begin{array}{l}\text { Cross-hatched incised and } \\
\text { punctated; cf. Dunkin Incised }\end{array}$ \\
\hline 45 & $\begin{array}{l}\text { grog/ } \\
\text { SP }\end{array}$ & Jar & D-FL & $\mathrm{F}$ & 7.1 & - & 7.4 & 8.8 & 4.0 & 0.39 & pinched-punctated elements \\
\hline 46 & $?$ & $\begin{array}{l}\text { Rattle bowl } \\
\text { with } 4 \text { legs } \\
\text { and ring base }\end{array}$ & INV-FL & B & 11.7 & I SM & 9.1 & 12.4 & 8.7 & 0.46 & pinched and incised elements \\
\hline 47 & $\begin{array}{l}\text { grog/ } \\
\text { SP }\end{array}$ & Jar & D-RO & G & 6.8 & I/E SM & 5.8 & 10.8 & 4.0 & 0.38 & $\begin{array}{l}\text { pinched-punctated-appliqued } \\
\text { elements* }\end{array}$ \\
\hline 48 & $?$ & $\begin{array}{l}\text { Jar with } 4 \\
\text { loop handles }\end{array}$ & EV-RO & B & 10.2 & I/E SM & 11.0 & 11.5 & 6.5 & 0.76 & Neck banded and appliqued \\
\hline 52 & $?$ & $\mathrm{CB}$ & INV-FL & A & 6.5 & $\begin{array}{l}\text { I SM/ } \\
\text { E B }\end{array}$ & 5.8 & 15.5 & 5.0 & 0.5 & Simms Engraved \\
\hline 54 & $\begin{array}{l}\text { grog- } \\
\text { bone }\end{array}$ & Jar & D-RO & $\mathrm{F}$ & 7.3 & I/E SM & 7.0 & 10.6 & 5.0 & 0.47 & $\begin{array}{l}\text { appliqued-pinched-punctated } \\
\text { elements* }\end{array}$ \\
\hline 57 & $\begin{array}{l}\text { bone- } \\
\text { grog }\end{array}$ & Jar & EV-RO & A & 7.6 & I SM & 6.5 & 9.5 & 5.0 & 0.38 & $\begin{array}{l}\text { appliqued-pinched-punctated } \\
\text { elements* }\end{array}$ \\
\hline 58 & $\begin{array}{l}\text { grog- } \\
\text { bone/ } \\
\text { SP }\end{array}$ & $\begin{array}{l}\text { Bowl with } \\
4 \text { legs and } \\
\text { ring base }\end{array}$ & D-FL & A & - & - & 9.8 & 11.0 & 8.5 & 0.43 & pinched and incised elements \\
\hline
\end{tabular}


Table 2. Vessels from Red River County, Texas, cont.

\begin{tabular}{|c|c|c|c|c|c|c|c|c|c|c|c|}
\hline Vessel No. & Temper & Vessel Form & $\begin{array}{l}\text { Rim- } \\
\text { Lip Form }\end{array}$ & $\begin{array}{l}\text { Firing } \\
\text { Cond. }\end{array}$ & $\begin{array}{l}\text { Th } \\
(\mathrm{mm})\end{array}$ & $\mathrm{ST}$ & $\begin{array}{l}\text { Height } \\
(\mathrm{cm})\end{array}$ & $\begin{array}{l}\text { OD } \\
(\mathrm{cm})\end{array}$ & $\begin{array}{l}\mathrm{BD} \\
(\mathrm{cm})\end{array}$ & $\begin{array}{l}\text { Vol. } \\
\text { (liters) }\end{array}$ & Type/Decoration \\
\hline 60 & $\begin{array}{l}\text { grog- } \\
\text { grit }\end{array}$ & $\begin{array}{l}\text { CPB with } \\
2 \text { strap } \\
\text { handles }\end{array}$ & EV-RO & A & 6.1 & - & 7.2 & 14.5 & 4.5 & 0.83 & cf. Avery Engraved (incised) \\
\hline 61 & $\begin{array}{l}\text { bone- } \\
\text { grog }\end{array}$ & Jar & EV-RO & $\mathrm{H}$ & 9.1 & I SM & 9.4 & 10.0 & 4.5 & 0.56 & punctated rows \\
\hline 63 & SP & Jar & EV-RO & B & 9.0 & - & 17.0 & 12.5 & 6.5 & 1.3 & cf. Nash Neck Banded \\
\hline 64 & $\begin{array}{l}\text { grog/ } \\
\text { SP }\end{array}$ & $\begin{array}{l}\text { Bowl with } \\
4 \text { legs }\end{array}$ & D-FL & A & - & - & 7.0 & 10.0 & 4.5 & 0.28 & $\begin{array}{l}\text { incised-pinched-punctated } \\
\text { elements }\end{array}$ \\
\hline 65 & grog & $\mathrm{CB}$ & INV-RO & $\mathrm{B}$ & - & $\begin{array}{l}\text { I SM/ } \\
\text { E B }\end{array}$ & 5.8 & 14.0 & 5.0 & 0.49 & Simms Engraved \\
\hline 66 & $\begin{array}{l}\text { grog- } \\
\text { bone }\end{array}$ & Jar & EV-RO & A & 7.7 & $\mathrm{I} / \mathrm{E} \mathrm{SM}$ & 7.2 & 10.0 & 4.0 & 0.43 & $\begin{array}{l}\text { appliqued-pinched or smoothed } \\
\text { over neck banded-punctated } \\
\text { elements }\end{array}$ \\
\hline 67 & $\begin{array}{l}\text { grog- } \\
\text { grit/ } \\
\text { SP }\end{array}$ & $\begin{array}{l}\text { Bowl with } \\
4 \text { legs and } \\
\text { ring base }\end{array}$ & INV-FL & A & - & - & 10.4 & 11.0 & 9.4 & 0.46 & pinched-incised elements \\
\hline 68 & grog & $\begin{array}{l}\text { Jar with } 2 \\
\text { strap handles }\end{array}$ & D-RO & A & 8.2 & I SM & 9.0 & 11.5 & 5.0 & 0.62 & fingernail punctated \\
\hline 69 & $\begin{array}{l}\text { grog/ } \\
\text { SP }\end{array}$ & $\begin{array}{l}\text { Jar with } 2 \\
\text { strap handles }\end{array}$ & D-FL & B & 10.6 & I SM & 9.0 & 10.8 & 5.5 & 0.58 & fingernail punctated \\
\hline 73 & $\begin{array}{l}\text { grog- } \\
\text { bone }\end{array}$ & Jar & EV-RO & B & 8.3 & - & 9.2 & 8.6 & 4.8 & 0.47 & $\begin{array}{l}\text { tool punctated, appliqued } \\
\text { nodes, and diagonal incised } \\
\text { lines }\end{array}$ \\
\hline 74 & bone & Jar & D-RO & B & 6.4 & - & 4.6 & 7.8 & 5.2 & 0.2 & incised-tool punctated panel \\
\hline $75 / 86$ & bone & Bowl & EV-RO & $\mathrm{F}$ & 8.5 & - & 4.2 & 8.0 & 4.3 & 0.13 & tool punctated-horizontal brushed \\
\hline 76 & bone & $\mathrm{CB}$ & $\begin{array}{l}\text { D-FL, ext. } \\
\text { thickened }\end{array}$ & B & 6.0 & E SM & 3.4 & 7.5 & 3.2 & 0.15 & tool punctated row \\
\hline 77 & $\begin{array}{l}\text { grog- } \\
\text { bone }\end{array}$ & $\mathrm{CB}$ & D-FL & $\mathrm{F}$ & 5.7 & $\mathrm{I} / \mathrm{E} \mathrm{B}$ & 5.8 & 14.2 & 5.5 & 0.50 & Simms Engraved (incised) \\
\hline 79 & grog & Jar with 3 legs & EV-RO & B & 8.7 & I/E SM & 8.1 & 9.4 & - & 0.46 & pinched row \\
\hline
\end{tabular}


Table 2. Vessels from Red River County, Texas, cont.

\begin{tabular}{|c|c|c|c|c|c|c|c|c|c|c|c|}
\hline Vessel No. & Temper & Vessel Form & $\begin{array}{l}\text { Rim- } \\
\text { Lip Form }\end{array}$ & $\begin{array}{l}\text { Firing } \\
\text { Cond. }\end{array}$ & $\begin{array}{l}\text { Th } \\
(\mathrm{mm})\end{array}$ & $\mathrm{ST}$ & $\begin{array}{l}\text { Height } \\
(\mathrm{cm})\end{array}$ & $\begin{array}{l}\mathrm{OD} \\
(\mathrm{cm})\end{array}$ & $\begin{array}{l}\mathrm{BD} \\
(\mathrm{cm})\end{array}$ & $\begin{array}{l}\text { Vol. } \\
\text { (liters) }\end{array}$ & Type/Decoration \\
\hline 80 & $?$ & $\begin{array}{l}\text { Canoe- } \\
\text { shaped } \\
\text { bowl }\end{array}$ & $-\mathrm{FL}$ & $\mathrm{F}$ & 9.8 & $\mathrm{I} / \mathrm{E} \mathrm{B}$ & 6.0 & 7.0 & - & 0.17 & engraved pendant triangles \\
\hline 81 & $\begin{array}{l}\text { grog- } \\
\text { bone- } \\
\text { hematite }\end{array}$ & Jar & EV-RO & G & 8.0 & $\mathrm{I} / \mathrm{E} \mathrm{SM}$ & 7.4 & 11.0 & 4.8 & 0.49 & $\begin{array}{l}\text { appliqued-pinched-punctated } \\
\text { elements* }\end{array}$ \\
\hline 82 & $\begin{array}{l}\text { bone- } \\
\text { grog/ } \\
\text { SP }\end{array}$ & Effigy bowl & D-FL & B & 7.2 & - & 9.2 & 10.6 & 6.3 & 0.39 & Horizontal incised lines \\
\hline 83 & $\begin{array}{l}\text { grog/ } \\
\text { SP }\end{array}$ & Bowl & INV-RO & A & - & E SM & 11.4 & 8.8 & 4.0 & 0.40 & circular punctated rows \\
\hline 84 & $\begin{array}{l}\text { grog- } \\
\text { bone }\end{array}$ & $\mathrm{CPB}$ & $\mathrm{D}-\mathrm{RO}$ & $\mathrm{F}$ & 6.9 & I SM & 5.5 & 9.5 & 4.0 & 0.31 & pinched-punctated rows \\
\hline 85 & $\begin{array}{l}\text { grog- } \\
\text { bone }\end{array}$ & Jar & $\mathrm{D}-\mathrm{RO}$ & $\mathrm{B}$ & 7.3 & $\mathrm{I} / \mathrm{E} \mathrm{SM}$ & 8.0 & 10.2 & 4.5 & 0.49 & $\begin{array}{l}\text { Cross-hatched incised-punctated- } \\
\text { appliqued elements }\end{array}$ \\
\hline 89 & grog & $\begin{array}{l}\text { Jar with } 4 \\
\text { strap handles }\end{array}$ & EV-RO & $\mathrm{B}$ & 8.4 & - & 16.0 & 13.0 & 6.0 & 1.25 & pinched and punctated; lip notched \\
\hline 90 & $\begin{array}{l}\text { grog- } \\
\text { bone/ } \\
\text { SP }\end{array}$ & $\begin{array}{l}\text { Bowl with } \\
4 \text { legs and } \\
\text { ring base }\end{array}$ & INV-RO & A & - & - & 10.2 & 10.5 & 9.0 & 0.43 & $\begin{array}{l}\text { curvilinear and vertical incised } \\
\text { lines }\end{array}$ \\
\hline 91 & grog & Beaker & D-RO, ext f & $\mathrm{H}$ & 7.7 & - & 12.8 & 13.8 & 10.0 & 1.4 & $\begin{array}{l}\text { Incised-punctated and pinched } \\
\text { elements }\end{array}$ \\
\hline 92 & $\begin{array}{l}\text { bone- } \\
\text { grog }\end{array}$ & $\begin{array}{l}\text { Bowl with } \\
4 \text { legs and } \\
\text { ring base }\end{array}$ & D-FL & $\mathrm{B}$ & - & - & 10.5 & 9.5 & 9.5 & 0.4 & pinched-grooved elements \\
\hline 93 & $\begin{array}{l}\text { grog/ } \\
\text { SP }\end{array}$ & Jar & EV-FL & $\mathrm{F}$ & 8.2 & I SM & 8.5 & 10.4 & 5.0 & 0.53 & $\begin{array}{l}\text { grooved-pinching-incised and } \\
\text { appliqued elements }\end{array}$ \\
\hline 94 & $\begin{array}{l}\text { grog- } \\
\text { bone- } \\
\text { grit }\end{array}$ & Jar & D-FL & $\mathrm{B}$ & 9.3 & - & 8.5 & 9.4 & 4.0 & 0.48 & $\begin{array}{l}\text { pinched-grooved-punctated } \\
\text { elements }\end{array}$ \\
\hline
\end{tabular}


Table 2. Vessels from Red River County, Texas, cont.

\begin{tabular}{|c|c|c|c|c|c|c|c|c|c|c|c|}
\hline Vessel No. & Temper & Vessel Form & $\begin{array}{l}\text { Rim- } \\
\text { Lip Form }\end{array}$ & $\begin{array}{l}\text { Firing } \\
\text { Cond. }\end{array}$ & $\begin{array}{l}\mathrm{Th} \\
(\mathrm{mm})\end{array}$ & ST & $\begin{array}{l}\text { Height } \\
(\mathrm{cm})\end{array}$ & $\begin{array}{l}\mathrm{OD} \\
(\mathrm{cm})\end{array}$ & $\begin{array}{l}\mathrm{BD} \\
(\mathrm{cm})\end{array}$ & $\begin{array}{l}\text { Vol. } \\
\text { (liters) }\end{array}$ & Type/Decoration \\
\hline 95 & grog & $\mathrm{CB}$ & D-FL & A & 8.9 & I/E SM & 6.8 & 18.9 & 7.0 & 0.76 & Davis Incised \\
\hline 96 & $\begin{array}{l}\text { grog- } \\
\text { bone }\end{array}$ & Jar & EV-RO & A & 7.8 & I/E SM & 7.5 & 11.5 & 5.0 & 0.52 & $\begin{array}{l}\text { pinched-appliqued-punctated- } \\
\text { grooved elements; lip notched* }\end{array}$ \\
\hline 97 & grog & $\mathrm{CB}$ & INV-RO & A & 6.7 & - & 6.0 & 17.2 & 7.0 & 0.62 & Simms Engraved (incised) \\
\hline 98 & grog & $\mathrm{CB}$ & D-FL & A & 8.9 & $\mathrm{I} / \mathrm{E} \mathrm{B}$ & 7.3 & 18.5 & 9.5 & 0.81 & Belcher Engraved? \\
\hline 99 & grog & Jar & D-RO & B & 9.3 & I/E SM & 8.0 & 10.4 & 4.5 & 0.5 & $\begin{array}{l}\text { appliqued, incised, punctated, and } \\
\text { pinched elements* }\end{array}$ \\
\hline 100 & grog & Jar & D-RO & A & 7.6 & I SM & 8.0 & 10.4 & 4.0 & 0.5 & $\begin{array}{l}\text { pinched, punctated, and appliqued } \\
\text { elements* }\end{array}$ \\
\hline 111 & $\begin{array}{l}\text { bone- } \\
\text { grog }\end{array}$ & Effigy bowl & D-RO & B & 11.5 & - & 7.5 & 9.2 & 5.5 & 0.28 & broad horizontal incised lines \\
\hline 112 & $\begin{array}{l}\text { grog- } \\
\text { grit }\end{array}$ & $\begin{array}{l}\text { Jar with } 2 \\
\text { strap handles }\end{array}$ & EV-RO & - & 9.5 & - & 9.0 & 12.0 & 6.0 & 0.65 & pinched rows \\
\hline 113 & $\begin{array}{l}\text { grog- } \\
\text { bone }\end{array}$ & Jar & EV-RO & B & 7.0 & I SM & 8.5 & 9.0 & 3.5 & 0.46 & $\begin{array}{l}\text { pinched, appliqued, grooved, and } \\
\text { punctated elements* }\end{array}$ \\
\hline 115 & bone & Jar & EV-RO & $\mathrm{B}$ & 9.5 & I SM & 7.4 & 9.6 & 5.0 & 0.43 & $\begin{array}{l}\text { pinched, punctated, and incised } \\
\text { elements }\end{array}$ \\
\hline 116 & $\begin{array}{l}\text { grog- } \\
\text { bone }\end{array}$ & $\mathrm{CB}$ & D-FL & G & 6.9 & I/E SM & 4.4 & 11.0 & 3.5 & 0.29 & Pennington Punctated-Incised \\
\hline 117 & grog & Jar & EV-RO & $\mathrm{F}$ & 7.8 & I SM & 7.4 & 10.4 & 6.5 & 0.46 & $\begin{array}{l}\text { Cross-hatched incised, punctated, } \\
\text { and appliqued elements }\end{array}$ \\
\hline 118 & grog & Conjoined jars & D-RO & B & 6.3 & - & 8.0 & 8.5 & 5.5 & 0.8 & $\begin{array}{l}\text { pinched, grooved, appliqued, and } \\
\text { punctated elements* }\end{array}$ \\
\hline 119 & $?$ & Jar & EV-RO & $\mathrm{F}$ & 7.6 & I SM & 5.5 & 9.2 & 4.5 & 0.3 & $\begin{array}{l}\text { appliqued, grooved, and } \\
\text { punctated elements* }\end{array}$ \\
\hline 120 & $\begin{array}{l}\text { grog/ } \\
\text { SP }\end{array}$ & Jar & EV-RO & A & 6.3 & I/E SM & 6.7 & 10.7 & 3.5 & 0.43 & $\begin{array}{l}\text { appliqued, pinched, and } \\
\text { punctated elements; lip } \\
\text { notched* }\end{array}$ \\
\hline
\end{tabular}


Table 2. Vessels from Red River County, Texas, cont.

\begin{tabular}{|c|c|c|c|c|c|c|c|c|c|c|c|}
\hline Vessel No. & Temper & Vessel Form & $\begin{array}{l}\text { Rim- } \\
\text { Lip Form }\end{array}$ & $\begin{array}{l}\text { Firing } \\
\text { Cond. }\end{array}$ & $\begin{array}{l}\text { Th } \\
(\mathrm{mm})\end{array}$ & ST & $\begin{array}{l}\text { Height } \\
(\mathrm{cm})\end{array}$ & $\begin{array}{l}\text { OD } \\
(\mathrm{cm})\end{array}$ & $\begin{array}{l}\mathrm{BD} \\
(\mathrm{cm})\end{array}$ & $\begin{array}{l}\text { Vol. } \\
\text { (liters) }\end{array}$ & Type/Decoration \\
\hline 121 & $\begin{array}{l}\text { grog- } \\
\text { bone/ } \\
\text { SP }\end{array}$ & Jar & EV-RO & $\mathrm{B}$ & 8.3 & I SM & 8.0 & 11.5 & 6.0 & 0.55 & $\begin{array}{l}\text { incised, punctated, and } \\
\text { appliqued elements }\end{array}$ \\
\hline 122 & $\begin{array}{l}\text { grog- } \\
\text { bone }\end{array}$ & Jar & $\mathrm{D}-\mathrm{RO}$ & G & 8.5 & I/E SM & 9.0 & 11.2 & 5.0 & 0.6 & appliqued-punctated elements \\
\hline 123 & bone & Jar & EV-RO & $\mathrm{B}$ & 7.3 & - & 7.2 & 9.3 & 4.3 & 0.4 & $\begin{array}{l}\text { pinched, punctated, and } \\
\text { grooved elements }\end{array}$ \\
\hline 124 & shell? & $\begin{array}{l}\text { Jar with } 2 \\
\text { loop handles }\end{array}$ & INV-FL & $?$ & 7.2 & I/E SM & 10.0 & 12.5 & 5.5 & 0.75 & $\begin{array}{l}\text { int. and ext. red-slipped; } \\
\text { appliqued nodes }\end{array}$ \\
\hline 127 & shell & Deep bowl & $\mathrm{D}-\mathrm{RO}$ & $\mathrm{A}$ & 6.3 & $\mathrm{I} / \mathrm{E} \mathrm{B}$ & 21.2 & 18.8 & 8.5 & 3.2 & Avery Engraved \\
\hline
\end{tabular}

*Boyce Appliqued-Punctated; Th=thickness; $\mathrm{ST}=$ surface treatment; $\mathrm{OD}=$ orifice diameter; $\mathrm{BD}=$ base diameter; $\mathrm{EV}=\mathrm{everted}$ rim; $\mathrm{D}=$ direct rim; $\mathrm{INV}=\mathrm{inverted}$ rim; $\mathrm{RO}=$ rounded lip; $\mathrm{FL}=$ flat; ext $\mathrm{f}=$ exterior folded; $\mathrm{I}=$ interior; $\mathrm{E}=$ exterior; $\mathrm{SM}=$ smoothed; $\mathrm{B}=$ burnished; $\mathrm{OR}=\mathrm{organic}$ residue; $\mathrm{SP}=\mathrm{sandy}$ paste; $\mathrm{CB}=$ carinated bowl; $\mathrm{CPB}=$ compound bowl 
Table 3. Vessels from Bowie County, Texas.

\begin{tabular}{|c|c|c|c|c|c|c|c|c|c|c|c|}
\hline Vessel No. & Temper & Vessel Form & $\begin{array}{l}\text { Rim- } \\
\text { Lip Form }\end{array}$ & $\begin{array}{l}\text { Firing } \\
\text { Cond. }\end{array}$ & $\begin{array}{l}\text { Th } \\
(\mathrm{mm})\end{array}$ & ST & $\begin{array}{l}\text { Height } \\
(\mathrm{cm})\end{array}$ & $\begin{array}{l}\text { OD } \\
(\mathrm{cm})\end{array}$ & $\begin{array}{l}\mathrm{BD} \\
(\mathrm{cm})\end{array}$ & $\begin{array}{l}\text { Vol. } \\
\text { (liters) }\end{array}$ & Type/Decoration \\
\hline 29 & $\begin{array}{l}\text { bone- } \\
\text { grog- } \\
\text { grit }\end{array}$ & Bowl & EV-RO & B & 5.0 & $\begin{array}{l}\text { I SM/ } \\
\text { E B }\end{array}$ & 10.2 & 12.4 & 7.6 & 0.76 & Engraved scroll and circle \\
\hline 105 & grog & Bottle & $\mathrm{D}-\mathrm{FL}$, ext $\mathrm{f}$ & G & - & $\begin{array}{l}\text { I SM/ } \\
\text { E B }\end{array}$ & 23.5 & 5.5 & 8.5 & 0.8 & Hatchel Engraved \\
\hline 128 & grog & $\mathrm{CB}$ & $\begin{array}{l}\text { D-FL, ext f; } \\
\text { sprocket lip }\end{array}$ & $\mathrm{B}$ & 9.1 & $\mathrm{I} / \mathrm{E} \mathrm{SM}$ & 16.4 & 33.6 & 14.5 & 4.9 & Engraved-punctated semi-circles \\
\hline
\end{tabular}

Th=thickness; $\mathrm{ST}=$ surface treatment; $\mathrm{OD}=$ orifice diameter; $\mathrm{BD}=$ base diameter; $\mathrm{EV}=$ everted rim; $\mathrm{D}=$ direct; $\mathrm{RO}=$ rounded lip; $\mathrm{FL}=$ flat lip; ext $\mathrm{f}=$ exterior folded; $\mathrm{I}=$ interior; $\mathrm{E}=$ exterior; $\mathrm{SM}=$ smoothed; $\mathrm{B}=$ burnished; $\mathrm{CB}=$ carinated bowl 
Table 4. Vessels from Harrison County, Texas.

\begin{tabular}{|c|c|c|c|c|c|c|c|c|c|c|c|}
\hline Vessel No. & Temper & Vessel Form & $\begin{array}{l}\text { Rim- } \\
\text { Lip Form }\end{array}$ & $\begin{array}{l}\text { Firing } \\
\text { Cond. }\end{array}$ & $\begin{array}{l}\text { Th } \\
(\mathrm{mm})\end{array}$ & ST & $\begin{array}{l}\text { Height } \\
(\mathrm{cm})\end{array}$ & $\begin{array}{l}\text { OD } \\
(\mathrm{cm})\end{array}$ & $\begin{array}{l}\mathrm{BD} \\
(\mathrm{cm})\end{array}$ & $\begin{array}{l}\text { Vol. } \\
\text { (liters) }\end{array}$ & Type/Decoration \\
\hline 21 & grog & Jar & EV-RO & $\mathrm{F}$ & 7.7 & I SM & 19.0 & 15.0 & 7.5 & 2.6 & Karnack Brushed-Incised \\
\hline 35 & $\begin{array}{l}\text { bone- } \\
\text { grog }\end{array}$ & Bottle & D-RO, ext f & $\mathrm{B}$ & 5.6 & $\begin{array}{l}\text { I SM/ } \\
\text { E B }\end{array}$ & 10.0 & 3.4 & 4.8 & 0.19 & Taylor Engraved \\
\hline 53 & grog & $\begin{array}{l}\text { Jar with } 4 \\
\text { strap handles }\end{array}$ & EV-RO & $\mathrm{B}$ & 6.0 & $\begin{array}{l}\text { I SM/ } \\
\text { I OR }\end{array}$ & 14.5 & 18.4 & 7.0 & 1.6 & Harleton Appliqued \\
\hline 114 & bone & Bottle & EV-RO & $\mathrm{B}$ & 6.0 & $\begin{array}{l}\text { I B/ } \\
\text { E P }\end{array}$ & 9.6 & 4.8 & 4.8 & 0.19 & $\begin{array}{l}\text { Engraved panels with circle } \\
\text { and cross; red pigment }\end{array}$ \\
\hline 148 & grog & $\mathrm{CB}$ & INV-RO & $\mathrm{B}$ & 6.2 & $\begin{array}{l}\text { I B/ } \\
\text { E P }\end{array}$ & 6.6 & 13.5 & 6.8 & 0.53 & Ripley Engraved; white pigment \\
\hline 153 & grog & Bottle & D-FL & $\mathrm{B}$ & 6.5 & $\begin{array}{l}\text { I B/ } \\
\text { E P }\end{array}$ & 17.0 & 5.0 & 8.0 & 0.54 & Engraved scrolls; red pigment \\
\hline 154 & $\begin{array}{l}\text { grog- } \\
\text { hematite }\end{array}$ & Bottle & D-FL & A & 6.2 & E SM & 24.0 & 4.5 & 8.5 & 0.8 & Plain \\
\hline 156 & shell? & Bottle & EV-RO & $\mathrm{F}$ & 5.8 & $\begin{array}{l}\text { I SM/ } \\
\text { E B }\end{array}$ & 9.0 & 4.6 & 4.8 & 0.17 & Wilder Engraved \\
\hline 158 & none & Bottle & EV-RO & $\mathrm{B}$ & 4.4 & $\begin{array}{l}\text { I B/ } \\
\text { E P }\end{array}$ & 19.6 & 5.0 & 6.8 & 0.53 & Wilder Engraved \\
\hline 159 & grog & Jar & $\mathrm{D}-\mathrm{RO}$ & $\mathrm{B}$ & 7.4 & $\begin{array}{l}\text { I SM/ } \\
\text { I OR }\end{array}$ & 18.8 & 15.5 & 11.0 & 2.6 & Pease Brushed-Incised \\
\hline 160 & grog & $\mathrm{CB}$ & INV-RO & $\mathrm{B}$ & 6.1 & $\begin{array}{l}\text { I SM/ } \\
\text { E B }\end{array}$ & 7.5 & 14.5 & 6.2 & 0.65 & Simms Engraved \\
\hline 161 & grog & Olla & D-FL & $\mathrm{G}$ & 7.1 & $\begin{array}{l}\text { I SM/ } \\
\text { E B }\end{array}$ & 24.0 & 8.5 & 10.0 & 1.9 & Wilder Engraved \\
\hline 162 & grog & $\mathrm{CB}$ & D-RO & $\mathrm{B}$ & 7.1 & $\mathrm{I} / \mathrm{E} \mathrm{B}$ & 14.0 & 25.8 & 10.5 & 3.2 & Ripley Engraved; red pigment \\
\hline 163 & grog & Deep bowl & D-RO, ext f & A & 4.2 & $\begin{array}{l}\text { I SM/ } \\
\text { E B }\end{array}$ & 10.5 & 13.5 & 5.5 & 1.1 & Horizontal engraved lines \\
\hline 165 & grog & Jar & EV-RO & $\mathrm{G}$ & 8.3 & I SM & 30.5 & 26.0 & 8.5 & 10.3 & Maydelle Incised \\
\hline 166 & grog & $\mathrm{CPB}$ & EV-RO & $\mathrm{F}$ & 8.7 & $\begin{array}{l}\text { I SM/ } \\
\text { E B }\end{array}$ & 23.0 & 35.5 & 8.5 & 6.5 & Ripley Engraved \\
\hline
\end{tabular}


Table 4. Vessels from Harrison County, Texas, cont.

\begin{tabular}{|c|c|c|c|c|c|c|c|c|c|c|c|}
\hline Vessel No. & Temper & Vessel Form & $\begin{array}{l}\text { Rim- } \\
\text { Lip Form }\end{array}$ & $\begin{array}{l}\text { Firing } \\
\text { Cond. }\end{array}$ & $\begin{array}{l}\text { Th } \\
(\mathrm{mm})\end{array}$ & ST & $\begin{array}{l}\text { Height } \\
(\mathrm{cm})\end{array}$ & $\begin{array}{l}\mathrm{OD} \\
(\mathrm{cm})\end{array}$ & $\begin{array}{l}\mathrm{BD} \\
(\mathrm{cm})\end{array}$ & $\begin{array}{l}\text { Vol. } \\
\text { (liters) }\end{array}$ & Type/Decoration \\
\hline 167 & bone & CB & D-RO & $\mathrm{A}$ & 5.4 & $\begin{array}{l}\text { I SM/ } \\
\text { E B }\end{array}$ & 4.5 & 12.5 & - & 0.34 & $\begin{array}{l}\text { Horizontal engraved scrolls; } \\
\text { Ripley Engraved }\end{array}$ \\
\hline 168 & grog & $\mathrm{CB}$ & D-RO, ext f & $\mathrm{B}$ & 5.2 & $\begin{array}{l}\text { I SM/ } \\
\text { E B }\end{array}$ & 8.5 & 21.7 & 8.0 & 1.1 & Ripley Engraved \\
\hline 171 & shell & Jar & EV-RO & $\mathrm{B}$ & 5.8 & $\mathrm{I} / \mathrm{E} \mathrm{SM}$ & 17.5 & 14.0 & 5.0 & 2.2 & Cowhide Stamped \\
\hline
\end{tabular}

Th=thickness; $\mathrm{ST}=$ surface treatment; $\mathrm{OD}=$ orifice diameter; $\mathrm{BD}=$ base diameter; $\mathrm{EV}=$ everted rim; $\mathrm{D}=\mathrm{direct}$;NV=inverted; $\mathrm{RO}=\mathrm{rounded}$ lip; $\mathrm{FL}=\mathrm{flat}$; ext $\mathrm{f}=$ exterior folded; $\mathrm{I}=$ interior; $\mathrm{E}=$ exterior; $\mathrm{SM}=$ smoothed; $\mathrm{B}=$ burnished; $\mathrm{P}=$ polished; $\mathrm{OR}=$ organic residue; $\mathrm{CB}=$ carinated bowl; $\mathrm{CPB}=\mathrm{compound}$ bowl 
Table 5. Vessels from Marion County, Texas.

\begin{tabular}{|c|c|c|c|c|c|c|c|c|c|c|c|}
\hline Vessel No. & Temper & Vessel Form & $\begin{array}{l}\text { Rim- } \\
\text { Lip Form }\end{array}$ & $\begin{array}{l}\text { Firing } \\
\text { Cond. }\end{array}$ & $\begin{array}{l}\mathrm{Th} \\
(\mathrm{mm})\end{array}$ & ST & $\begin{array}{l}\text { Height } \\
(\mathrm{cm})\end{array}$ & $\begin{array}{l}\text { OD } \\
(\mathrm{cm})\end{array}$ & $\begin{array}{l}\mathrm{BD} \\
(\mathrm{cm})\end{array}$ & $\begin{array}{l}\text { Vol. } \\
\text { (liters) }\end{array}$ & Type/Decoration \\
\hline 17 & grog & $\mathrm{CB}$ & D-RO, ext f & $\mathrm{B}$ & 6.0 & $\mathrm{I} / \mathrm{E} \mathrm{B}$ & 11.5 & 29.5 & 8.8 & 2.0 & Ripley Engraved \\
\hline 19 & grog & $\mathrm{CB}$ & INV-RO, ext f & $\mathrm{F}$ & 6.9 & $\begin{array}{l}\text { I SM/ } \\
\text { E B }\end{array}$ & 15.5 & 29.0 & 9.5 & 4.0 & Diagonal engraved zones \\
\hline 49 & grog & $\mathrm{CB}$ & D-RO & $\mathrm{F}$ & 6.3 & $\mathrm{I} / \mathrm{E} \mathrm{B}$ & 11.7 & 23.5 & 7.5 & 1.65 & Ripley Engraved \\
\hline 136 & grog & Bottle & EV-RO & $?$ & 5.4 & I/E B & 22.7 & 5.2 & 8.0 & 0.73 & Bailey Engraved; red pigment \\
\hline 138 & grog & Olla & D-RO & G & 6.1 & I SM & 29.5 & 10.1 & 9.8 & 2.4 & Clements Brushed \\
\hline 139 & grog & $\begin{array}{l}\text { Jar with } 4 \\
\text { strap handles }\end{array}$ & EV-RO & B & 6.6 & I SM & 17.0 & 22.0 & 8.0 & 3.3 & Harleton Appliqued \\
\hline 140 & grog & Olla & EV-RO & $\mathrm{B}$ & 4.0 & $\begin{array}{l}\text { I SM/ } \\
\text { E P }\end{array}$ & 8.1 & 5.0 & 5.7 & 0.37 & Belcher Engraved \\
\hline 141 & grog & Bottle & $\mathrm{D}-\mathrm{RO}$, ext $\mathrm{f}$ & G & 3.4 & E B & 7.4 & 2.5 & 2.9 & 0.1 & $\begin{array}{l}\text { Engraved panels; cf. Taylor } \\
\text { Engraved; red pigment }\end{array}$ \\
\hline
\end{tabular}

$\mathrm{Th}=$ thickness; $\mathrm{ST}=$ surface treatment; $\mathrm{OD}=$ orifice diameter; $\mathrm{BD}=$ base diameter; $\mathrm{EV}=$ everted rim; $\mathrm{D}=$ direct; $\mathrm{INV}=$ inverted; $\mathrm{RO}=$ rounded lip; ext $\mathrm{f}=$ exterior folded; $\mathrm{I}=$ interior; $\mathrm{E}=$ exterior; $\mathrm{SM}=$ smoothed; $\mathrm{B}=$ burnished; $\mathrm{P}=$ polished; $\mathrm{CB}=$ carinated bowl 
Table 6. Vessels from Camp County, Texas.

\begin{tabular}{|c|c|c|c|c|c|c|c|c|c|c|c|}
\hline Vessel No. & Temper & Vessel Form & $\begin{array}{l}\text { Rim- } \\
\text { Lip Form }\end{array}$ & $\begin{array}{l}\text { Firing } \\
\text { Cond. }\end{array}$ & $\begin{array}{l}\mathrm{Th} \\
(\mathrm{mm})\end{array}$ & $\mathrm{ST}$ & $\begin{array}{l}\text { Height } \\
(\mathrm{cm})\end{array}$ & $\begin{array}{l}\text { OD } \\
(\mathrm{cm})\end{array}$ & $\begin{array}{l}\mathrm{BD} \\
(\mathrm{cm})\end{array}$ & $\begin{array}{l}\text { Vol. } \\
\text { (liters) }\end{array}$ & Type/Decoration \\
\hline 20 & grog & CB & EV-RO & A & 6.7 & - & 13.4 & 15.2 & 8.5 & 1.2 & $\begin{array}{l}\text { Ripley Engraved; int. and ext. } \\
\text { red-slipped }\end{array}$ \\
\hline 24 & grog & $\mathrm{CPB}$ & D-RO & $\mathrm{A}$ & 9.3 & $\begin{array}{l}\text { I SM/ } \\
\text { E B }\end{array}$ & 26.0 & 36.5 & 10.0 & 7.6 & $\begin{array}{l}\text { Taylor Engraved; red and white } \\
\text { pigments }\end{array}$ \\
\hline 26 & grog & Jar & D-RO & G & 7.7 & $\begin{array}{l}\text { I SM/ } \\
\text { I OR }\end{array}$ & 21.0 & 16.0 & 9.5 & 3.0 & Harleton Appliqued \\
\hline 27 & grog & $\mathrm{CB}$ & D-RO & $\mathrm{G}$ & 6.7 & $\mathrm{I} / \mathrm{E} \mathrm{B}$ & 13.5 & 27.4 & 8.0 & 3.3 & Ripley Engraved \\
\hline 28 & grog & $\mathrm{CB}$ & D-RO, ext f & $\mathrm{B}$ & 7.3 & $\mathrm{I} / \mathrm{E} \mathrm{B}$ & 11.4 & 28.5 & 10.0 & 1.95 & Ripley Engraved; white pigment \\
\hline 145 & grog & Jar & EV-RO & G & 9.3 & I SM & 14.0 & 13.5 & 6.5 & 1.1 & Maydelle Incised \\
\hline 164 & grog & $\begin{array}{l}\text { Jar with } 2 \\
\text { loop handles }\end{array}$ & EV-RO & G & 7.9 & I SM & 12.5 & 18.8 & 10.5 & 1.4 & Harleton Appliqued \\
\hline
\end{tabular}

$\mathrm{Th}=$ thickness; $\mathrm{ST}=$ surface treatment; $\mathrm{OD}=$ orifice diameter; $\mathrm{BD}=$ base diameter; $\mathrm{EV}=$ everted rim; $\mathrm{D}=$ direct; $\mathrm{RO}=\mathrm{rounded}$ lip; $\mathrm{I}=$ interior; $\mathrm{E}=\mathrm{exterior}$; $\mathrm{SM}=$ smoothed; $\mathrm{B}=$ burnished; $\mathrm{OR}=$ organic residue; $\mathrm{CB}=$ carinated bowl; $\mathrm{CPB}=$ compound bowl 
Table 7. Vessels from Upshur County, Texas.

\begin{tabular}{|c|c|c|c|c|c|c|c|c|c|c|c|}
\hline Vessel No. & Temper & Vessel Form & $\begin{array}{l}\text { Rim- } \\
\text { Lip Form }\end{array}$ & $\begin{array}{l}\text { Firing } \\
\text { Cond. }\end{array}$ & $\begin{array}{l}\text { Th } \\
(\mathrm{mm})\end{array}$ & ST & $\begin{array}{l}\text { Height } \\
(\mathrm{cm})\end{array}$ & $\begin{array}{l}\text { OD } \\
(\mathrm{cm})\end{array}$ & $\begin{array}{l}\mathrm{BD} \\
(\mathrm{cm})\end{array}$ & $\begin{array}{l}\text { Vol. } \\
\text { (liters) }\end{array}$ & Type/Decoration \\
\hline 126 & grog & $\begin{array}{l}\text { Jar-4 strap } \\
\text { handles }\end{array}$ & EV-RO & $\mathrm{G}$ & 7.1 & I SM & 18.5 & 19.5 & 8.0 & 3.2 & Harleton Appliqued \\
\hline 130 & $\begin{array}{l}\text { grog/ } \\
\text { SP }\end{array}$ & Jar & $\mathrm{D}-\mathrm{RO}$ & G & 6.2 & I OR & 20.0 & 14.5 & 9.5 & 2.6 & cf. Pease Brushed-Incised \\
\hline 131 & $\begin{array}{l}\text { grog- } \\
\text { bone }\end{array}$ & Jar & EV-RO & G & 6.6 & $\begin{array}{l}\text { I SM; } \\
\text { I OR }\end{array}$ & 14.2 & 13.0 & 7.0 & 1.2 & Cass Appliqued \\
\hline 132 & grog & Jar & $\mathrm{D}-\mathrm{RO}$ & G & 6.3 & $\begin{array}{l}\text { I SM; } \\
\text { E OR }\end{array}$ & 16.0 & 12.5 & 9.0 & 1.7 & Cass Appliqued \\
\hline 133 & grog & $\mathrm{CB}$ & $\mathrm{D}-\mathrm{RO}$ & $\mathrm{F}$ & 5.8 & $\mathrm{I} / \mathrm{E} \mathrm{B}$ & 13.8 & 28.0 & 9.5 & 3.4 & Ripley Engraved \\
\hline 135 & grog & $\begin{array}{l}\text { Jar-4 loop } \\
\text { handles }\end{array}$ & EV-RO & A & 6.5 & - & 17.0 & 16.5 & 7.0 & 2.5 & Harleton Appliqued \\
\hline 142 & grog & jar & EV-RO & G & 8.1 & I SM & 14.5 & 13.8 & 8.7 & 1.2 & $\begin{array}{l}\text { vertical appliqued-pinched; } \\
\text { Cass Appliqued }\end{array}$ \\
\hline 143 & grog & $\mathrm{CPB}$ & EV-RO & $?$ & 8.1 & $\mathrm{I} / \mathrm{E} \mathrm{B}$ & 24.5 & 34.4 & 10.0 & 6.7 & Taylor Engraved; red-slipped \\
\hline 144 & grog & $\mathrm{CPB}$ & D-RO, ext f & $\mathrm{B}$ & 7.6 & $\mathrm{I} / \mathrm{E} \mathrm{B}$ & 25.8 & 32.5 & 9.0 & 6.7 & Taylor Engraved \\
\hline 151 & grog & Bowl & $\mathrm{D}-\mathrm{RO}$ & A & 5.4 & I SM & 6.5 & 11.0 & 4.5 & 0.29 & Moore Noded rattle bowl \\
\hline
\end{tabular}

Th=thickness; $\mathrm{ST}=$ surface treatment; $\mathrm{OD}=$ orifice diameter; $\mathrm{BD}=$ base diameter; $\mathrm{EV}=$ everted rim; $\mathrm{D}=$ direct rim; $\mathrm{RO}=\mathrm{rounded}$ lip; ext $\mathrm{f}=\mathrm{exterior}$ folded; $\mathrm{I}=$ interior; $\mathrm{E}=$ exterior; $\mathrm{SM}=$ smoothed; $\mathrm{B}=$ burnished; $\mathrm{OR}=$ organic residue; $\mathrm{SP}=$ sandy paste; $\mathrm{CB}=$ carinated bowl; $\mathrm{CPB}=$ compound bowl 
Table 8. Vessels from Cherokee County, Texas.

\begin{tabular}{|c|c|c|c|c|c|c|c|c|c|c|c|}
\hline Vessel No. & Temper & Vessel Form & $\begin{array}{l}\text { Rim- } \\
\text { Lip Form }\end{array}$ & $\begin{array}{l}\text { Firing } \\
\text { Cond. }\end{array}$ & $\begin{array}{l}\mathrm{Th} \\
(\mathrm{mm})\end{array}$ & $\mathrm{ST}$ & $\begin{array}{l}\text { Height } \\
(\mathrm{cm})\end{array}$ & $\begin{array}{l}\text { OD } \\
(\mathrm{cm})\end{array}$ & $\begin{array}{l}\mathrm{BD} \\
(\mathrm{cm})\end{array}$ & $\begin{array}{l}\text { Vol. } \\
\text { (liters) }\end{array}$ & Type/Decoration \\
\hline 4 & bone & $\begin{array}{l}\text { Bowl with } \\
\text { scalloped rim }\end{array}$ & $\begin{array}{l}\text { D-RO, int. } \\
\text { thickened }\end{array}$ & $\mathrm{A}$ & 8.6 & $\mathrm{I} / \mathrm{E} \mathrm{SM}$ & 11.3 & 42.5 & 10.0 & 2.8 & $\begin{array}{l}\text { Engraved nested triangles on } \\
\text { interior thickened rim; cf. } \\
\text { Sanders Engraved }\end{array}$ \\
\hline 182 & bone & $\mathrm{CB}$ & EV-RO & A & 6.7 & I/E SM & 12.5 & 20.0 & 9.0 & 1.5 & Opposed engraved lines \\
\hline 183 & bone & Jar & D-RO & $?$ & 5.2 & - & 12.0 & 12.0 & 6.6 & 0.86 & Vertical pinched rows \\
\hline 189 & grog & Olla & $\mathrm{D}-\mathrm{RO}$, ext $\mathrm{f}$ & G & 8.0 & $\begin{array}{l}\text { I SM/ } \\
\text { E B }\end{array}$ & 24.2 & 9.0 & 7.0 & 1.35 & $\begin{array}{l}\text { Interlocking engraved scrolls; } \\
\text { red pigment, cf. Taylor Engraved }\end{array}$ \\
\hline
\end{tabular}

Th=thickness; $\mathrm{ST}=$ surface treatment; $\mathrm{OD}=$ orifice diameter; $\mathrm{BD}=$ base diameter; $\mathrm{EV}=$ everted rim; $\mathrm{D}=$ direct; $\mathrm{RO}=$ rounded lip; ext $\mathrm{f}=$ exterior folded; $\mathrm{I}=$ interior; $\mathrm{E}=$ exterior; $\mathrm{SM}=$ smoothed; $\mathrm{B}=$ burnished; $\mathrm{CB}=$ carinated bowl 
Table 9. Vessels from Smith County, Texas.

\begin{tabular}{|c|c|c|c|c|c|c|c|c|c|c|c|}
\hline Vessel No. & Temper & Vessel Form & $\begin{array}{l}\text { Rim- } \\
\text { Lip Form }\end{array}$ & $\begin{array}{l}\text { Firing } \\
\text { Cond. }\end{array}$ & $\begin{array}{l}\text { Th } \\
(\mathrm{mm})\end{array}$ & ST & $\begin{array}{l}\text { Height } \\
(\mathrm{cm})\end{array}$ & $\begin{array}{l}\mathrm{OD} \\
(\mathrm{cm})\end{array}$ & $\begin{array}{l}\mathrm{BD} \\
(\mathrm{cm})\end{array}$ & $\begin{array}{l}\text { Vol. } \\
\text { (liters) }\end{array}$ & Type/Decoration \\
\hline 1 & grog & $\mathrm{CB}$ & EV-RO & $\mathrm{B}$ & 5.8 & E SM & 7.6 & 12.0 & 7.8 & 0.37 & Poynor Engraved, var. Hood \\
\hline 5 & grog & $\begin{array}{l}\text { Jar or beaker; } \\
2 \text { sets of } \\
\text { suspension holes }\end{array}$ & EV-RO & $\mathrm{B}$ & 4.8 & $\mathrm{I} / \mathrm{E} \mathrm{B}$ & 10.6 & 10.2 & 8.8 & 0.65 & $\begin{array}{l}\text { Vertical pendant triangles and } \\
\text { engraved semi-circles }\end{array}$ \\
\hline 22 & grog & $\mathrm{CB}$ & D-RO & $\mathrm{H}$ & 6.0 & $\mathrm{I} / \mathrm{E} \mathrm{B}$ & 11.5 & 16.0 & 9.0 & 1.1 & Poynor Engraved, var. Hood \\
\hline 23 & $\begin{array}{l}\text { grog- } \\
\text { hematite }\end{array}$ & $\mathrm{CB}$ & $\mathrm{D}-\mathrm{RO}$ & $\mathrm{A}$ & 5.2 & I SM & 13.0 & 17.7 & 7.0 & 1.4 & Poynor Engraved, var. Hood \\
\hline 25 & grog & $\mathrm{CB}$ & INV-RO & $\mathrm{A}$ & 6.4 & $\begin{array}{l}\text { I SM/ } \\
\text { E B }\end{array}$ & 15.5 & 28.2 & 9.5 & 3.9 & Poynor Engraved, var. E \\
\hline 50 & grog & $\mathrm{CB}$ & D-RO & A & 5.1 & $\begin{array}{l}\text { I SM/ } \\
\text { E B }\end{array}$ & 8.8 & 14.2 & 8.0 & 0.75 & Poynor Engraved, var. Hood \\
\hline 51 & $\begin{array}{l}\text { grog- } \\
\text { hematite }\end{array}$ & $\begin{array}{l}\text { Bowl with } \\
\text { ring base }\end{array}$ & INV-FL & A & - & - & 11.0 & 10.5 & 8.5 & 0.46 & $\begin{array}{l}\text { Vertical and semi-circular } \\
\text { incised lines }\end{array}$ \\
\hline 88 & grog & Bottle & D-FL & $\mathrm{B}$ & 7.3 & $\begin{array}{l}\text { I SM/ } \\
\text { E B }\end{array}$ & 20.5 & 5.2 & 7.5 & 0.61 & Hume Engraved \\
\hline 125 & grog & $\begin{array}{l}\text { Bowl, probable } \\
\text { effigy }\end{array}$ & D-FL & $\mathrm{B}$ & 6.0 & $\mathrm{I} / \mathrm{E} \mathrm{SM}$ & 5.1 & 9.5 & 6.1 & 0.19 & Hood Engraved, var. unspecified \\
\hline 149 & $\begin{array}{l}\text { grog- } \\
\text { hematite }\end{array}$ & Effigy bowl & D-RO & $\mathrm{A}$ & 5.5 & $\mathrm{I} / \mathrm{E} \mathrm{SM}$ & 8.5 & 15.0 & 9.0 & 0.51 & Hood Engraved, var. Hood \\
\hline
\end{tabular}


Table 10. Vessels from Clark County, Arkansas.

\begin{tabular}{|c|c|c|c|c|c|c|c|c|c|c|c|}
\hline Vessel No. & Temper & Vessel Form & $\begin{array}{l}\text { Rim- } \\
\text { Lip Form }\end{array}$ & $\begin{array}{l}\text { Firing } \\
\text { Cond. }\end{array}$ & $\begin{array}{l}\text { Th } \\
(\mathrm{mm})\end{array}$ & ST & $\begin{array}{l}\text { Height } \\
(\mathrm{cm})\end{array}$ & $\begin{array}{l}\text { OD } \\
(\mathrm{cm})\end{array}$ & $\begin{array}{l}\mathrm{BD} \\
(\mathrm{cm})\end{array}$ & $\begin{array}{l}\text { Vol. } \\
\text { (liters) }\end{array}$ & Type/Decoration \\
\hline 6 & grog & Bottle & D-RO & $\mathrm{B}$ & 5.0 & $\begin{array}{l}\text { I SM/ } \\
\text { E B }\end{array}$ & 24.5 & 4.2 & 7.0 & 0.69 & Means Engraved; red pigment \\
\hline 34 & $?$ & Bottle & D-RO & $\mathrm{F}$ & - & $\mathrm{I} / \mathrm{E} \mathrm{B}$ & 23.5 & 4.8 & 7.5 & 0.70 & Engraved panels \\
\hline 41 & grog & Jar & D-RO & $\mathrm{B}$ & 5.3 & I SM & 15.2 & 14.5 & 7.2 & 1.3 & Military Road Incised \\
\hline 59 & grog & $\mathrm{CB}$ & $\begin{array}{l}\text { D-RO; } \\
\text { sprocket lip }\end{array}$ & B & 4.9 & $\mathrm{I} / \mathrm{E} \mathrm{B}$ & 6.0 & 19.5 & - & 0.70 & Friendship Engraved; red pigment \\
\hline 62 & grog & Jar & D-RO & G & 6.1 & I SM & 15.4 & 13.5 & 11.0 & 1.2 & Military Road Incised \\
\hline 85 & $?$ & $\mathrm{CB}$ & D-RO & $\mathrm{B}$ & 5.1 & $\mathrm{I} / \mathrm{E} \mathrm{B}$ & - & 17.0 & - & $\mathrm{N} / \mathrm{A}$ & Friendship Engraved \\
\hline 87 & shell & Bottle & $\mathrm{D}-\mathrm{RO}$ & B & 5.4 & E SM & 8.6 & 3.4 & 4.1 & 0.14 & Plain \\
\hline 106 & $?$ & $\begin{array}{l}\text { Beaker or CPB; } \\
\text { suspension } \\
\text { holes }\end{array}$ & D-FL & B & 5.3 & $\begin{array}{l}\text { I SM/ } \\
\text { E B }\end{array}$ & 16.4 & 11.4 & 9.4 & 1.3 & Engraved ladders and circles \\
\hline 110 & grog & Bottle & D-FL & $\mathrm{B}$ & 4.1 & E B & 18.0 & 4.2 & 8.2 & 0.6 & $\begin{array}{l}\text { Adair Engraved. var. Adair; red } \\
\text { pigment }\end{array}$ \\
\hline 146 & grog & $\mathrm{CB}$ & $\begin{array}{l}\text { D-RO, ext f; } \\
\text { sprocket lip }\end{array}$ & $?$ & 5.6 & $\mathrm{I} / \mathrm{E} \mathrm{P}$ & 6.0 & 19.0 & - & 0.68 & Friendship Engraved \\
\hline 169 & shell & Bottle & D-RO, ext f & $\mathrm{B}$ & 4.7 & $\begin{array}{l}\text { I SM/ } \\
\text { E B }\end{array}$ & 14.5 & 4.5 & 6.7 & 0.36 & Hudson Engraved; red pigment \\
\hline 170 & grog & Bottle & D-FL & $\mathrm{B}$ & 5.3 & $\mathrm{I} / \mathrm{E} \mathrm{B}$ & 21.0 & 4.5 & 8.0 & 0.67 & Friendship Engraved; red pigment \\
\hline 172 & grog & Bottle & D-FL & $\mathrm{B}$ & 5.3 & E P & 16.0 & 4.8 & - & $\mathrm{N} / \mathrm{A}$ & Means Engraved?; red pigment \\
\hline 173 & $\begin{array}{l}\text { grog- } \\
\text { shell }\end{array}$ & Bottle & D-RO, ext f & $\mathrm{B}$ & 4.9 & $\mathrm{I} / \mathrm{E} \mathrm{B}$ & 19.0 & 4.2 & - & $\mathrm{N} / \mathrm{A}$ & Belcher Engraved, var. Manchester \\
\hline
\end{tabular}

Th=thickness; $\mathrm{ST}=$ surface treatment; $\mathrm{OD}=$ orifice diameter; $\mathrm{BD}=$ base diameter; $\mathrm{D}=$ direct; $\mathrm{RO}=$ rounded lip; $\mathrm{FL}=$ flat lip; ext $\mathrm{f}=\mathrm{exterior}$ folded; $\mathrm{I}=$ interior;

$\mathrm{E}=$ exterior; $\mathrm{SM}=$ smoothed; $\mathrm{B}=$ burnished; $\mathrm{P}=$ polished; $\mathrm{CB}=$ carinated bowl 
Table 11. Vessels from miscellaneous contexts in Arkansas.

\begin{tabular}{|c|c|c|c|c|c|c|c|c|c|c|c|}
\hline Vessel No. & Temper & Vessel Form & $\begin{array}{l}\text { Rim- } \\
\text { Lip Form }\end{array}$ & $\begin{array}{l}\text { Firing } \\
\text { Cond. }\end{array}$ & $\begin{array}{l}\mathrm{Th} \\
(\mathrm{mm})\end{array}$ & ST & $\begin{array}{l}\text { Height } \\
(\mathrm{cm})\end{array}$ & $\begin{array}{l}\text { OD } \\
(\mathrm{cm})\end{array}$ & $\begin{array}{l}\mathrm{BD} \\
(\mathrm{cm})\end{array}$ & $\begin{array}{l}\text { Vol. } \\
\text { (liters) }\end{array}$ & Type/Decoration \\
\hline
\end{tabular}

\section{Unknown County}

2

shell Bottle

D-FL

B

$5.4 \quad \mathrm{I} \mathrm{B} /$
$\mathrm{E} \mathrm{P}$

I B/
E P

20.0

7.0

N/A Adair Engraved

\section{Southern Arkansas}

157

\section{Faulkner County}

177

? Bottle

D-FL

$?$

4.8

I/E P

$22.5 \quad 5.1$

10.0

0.90

Engraved vertical scrolls

\section{Grant County}

129

grog Bottle

D-RO, ext f

B

E B

$22.5 \quad 4.1$

8.3

0.70

Friendship Engraved?; red pigment

\section{Lee County}

103

shell Bottle

$$
-
$$

\section{Pike County}

107

grog Jar

D-RO

G

$6.2 \quad$ I SM $\quad 16.0$

$12.8 \quad 9.8$
incised panels, cf. Dunkin Incised 
Table 12. Vessels from LeFlore County, Oklahoma.

\begin{tabular}{|c|c|c|c|c|c|c|c|c|c|c|c|}
\hline Vessel No. & Temper & Vessel Form & $\begin{array}{l}\text { Rim- } \\
\text { Lip Form }\end{array}$ & $\begin{array}{l}\text { Firing } \\
\text { Cond. }\end{array}$ & $\begin{array}{l}\text { Th } \\
(\mathrm{mm})\end{array}$ & ST & $\begin{array}{l}\text { Height } \\
(\mathrm{cm})\end{array}$ & $\begin{array}{l}\text { OD } \\
(\mathrm{cm})\end{array}$ & $\begin{array}{l}\mathrm{BD} \\
(\mathrm{cm})\end{array}$ & $\begin{array}{l}\text { Vol. } \\
\text { (liters) }\end{array}$ & Type/Decoration \\
\hline 109 & $?$ & Bottle & D-FL & G & 6.2 & I/E SM & 19.0 & 4.9 & 6.5 & 0.5 & $\begin{array}{l}\text { Engraved circles and vertical } \\
\text { hooked arm elements }\end{array}$ \\
\hline
\end{tabular}

$\mathrm{Th}=$ thickness; $\mathrm{ST}=$ surface treatment; $\mathrm{OD}=$ orifice diameter; $\mathrm{BD}=$ base diameter; $\mathrm{D}=$ direct; $\mathrm{FL}=$ flat lip; $\mathrm{I}=$ interior; $\mathrm{E}=$ exterior; $\mathrm{SM}=$ smoothed 


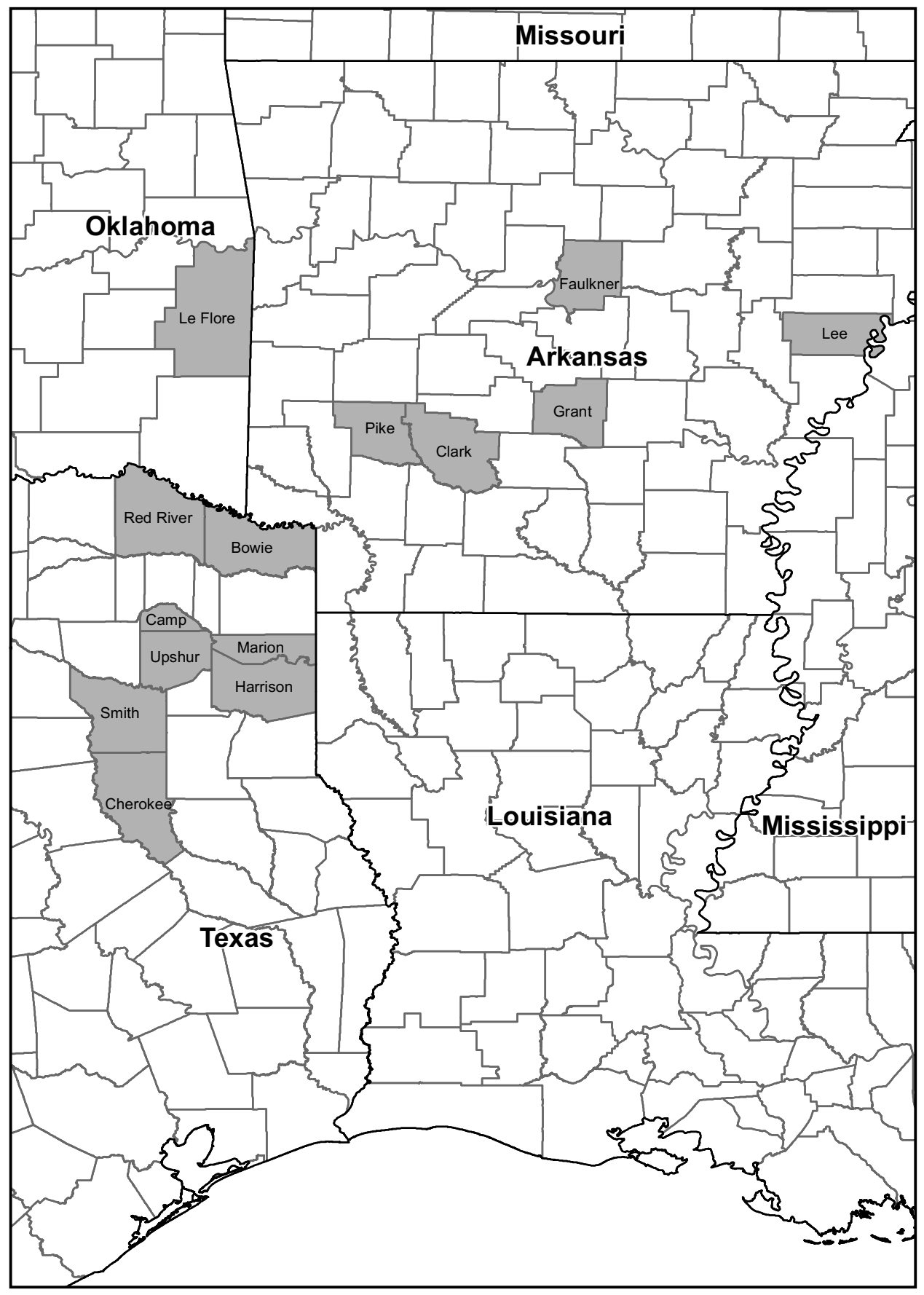

Figure 1 


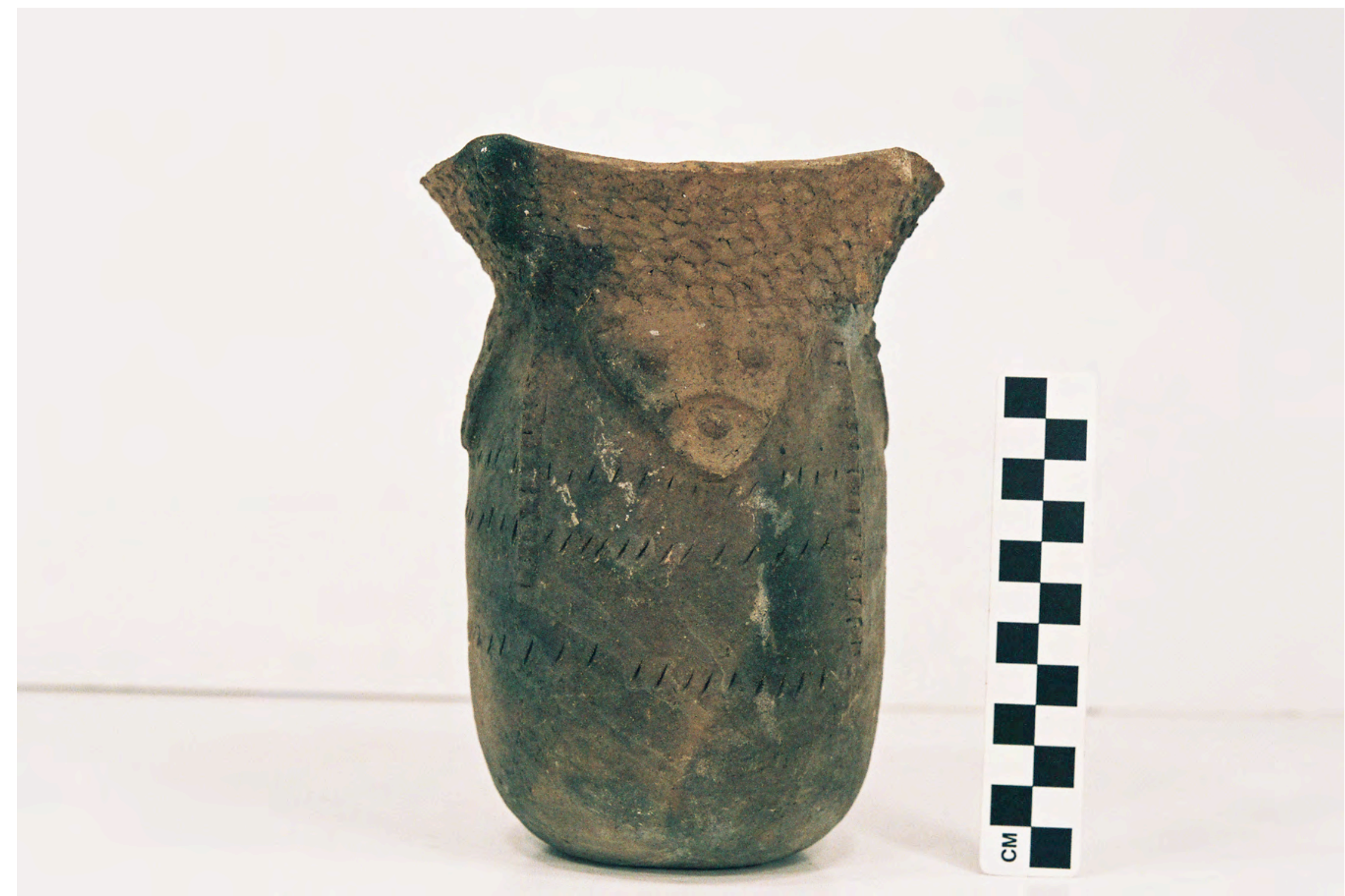

Figure 2a 


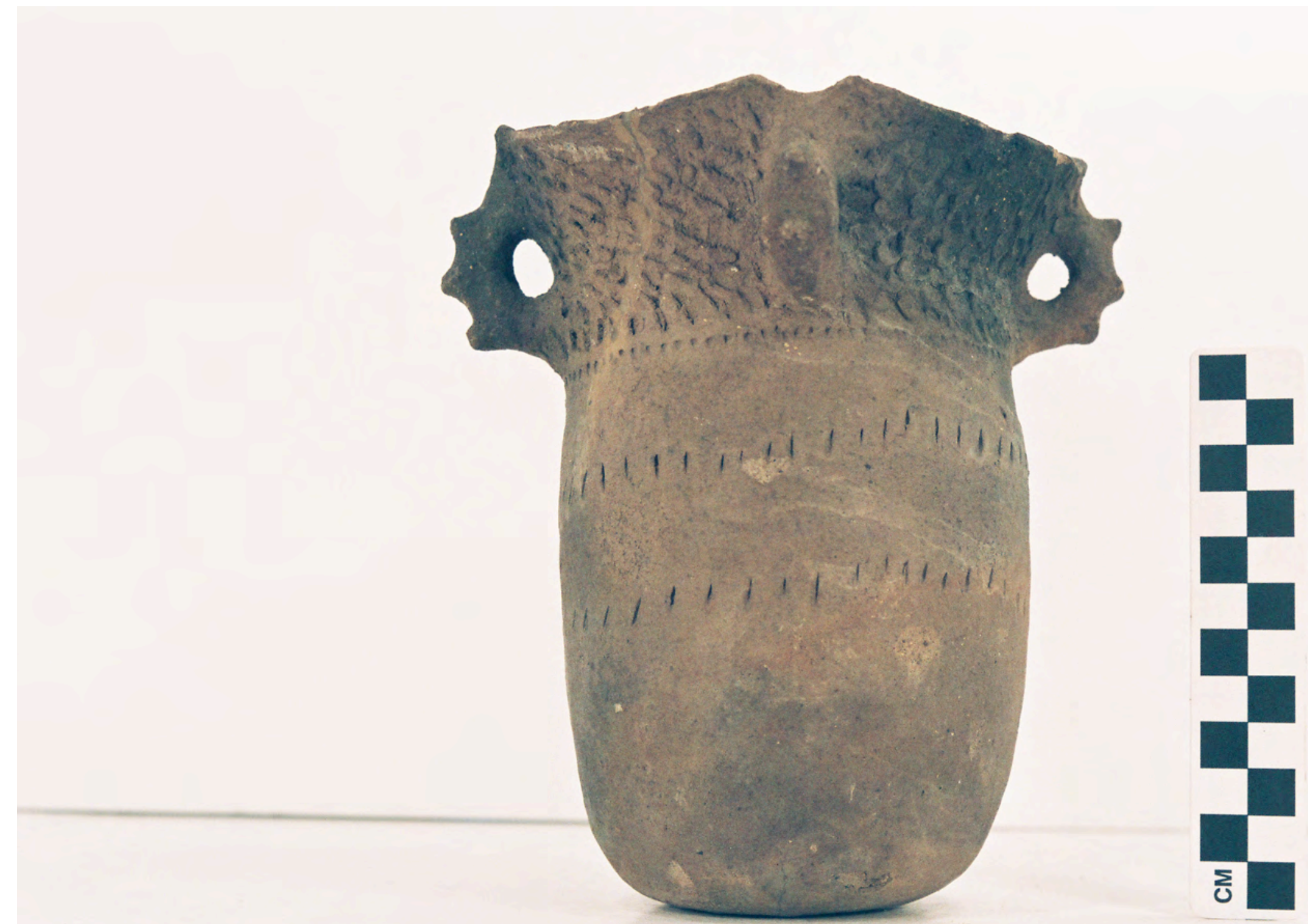

Figure $2 b$ 


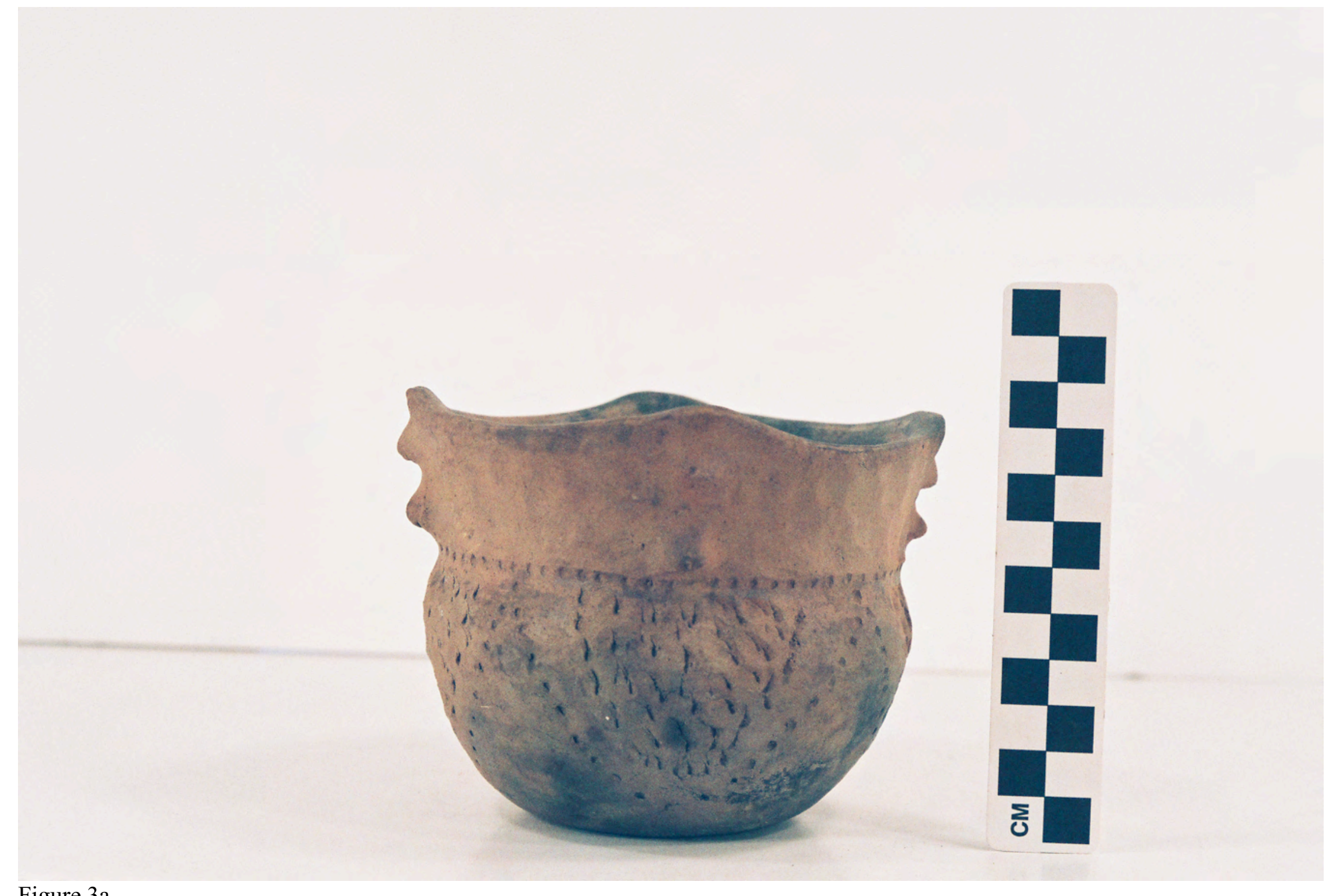

Figure 3a 


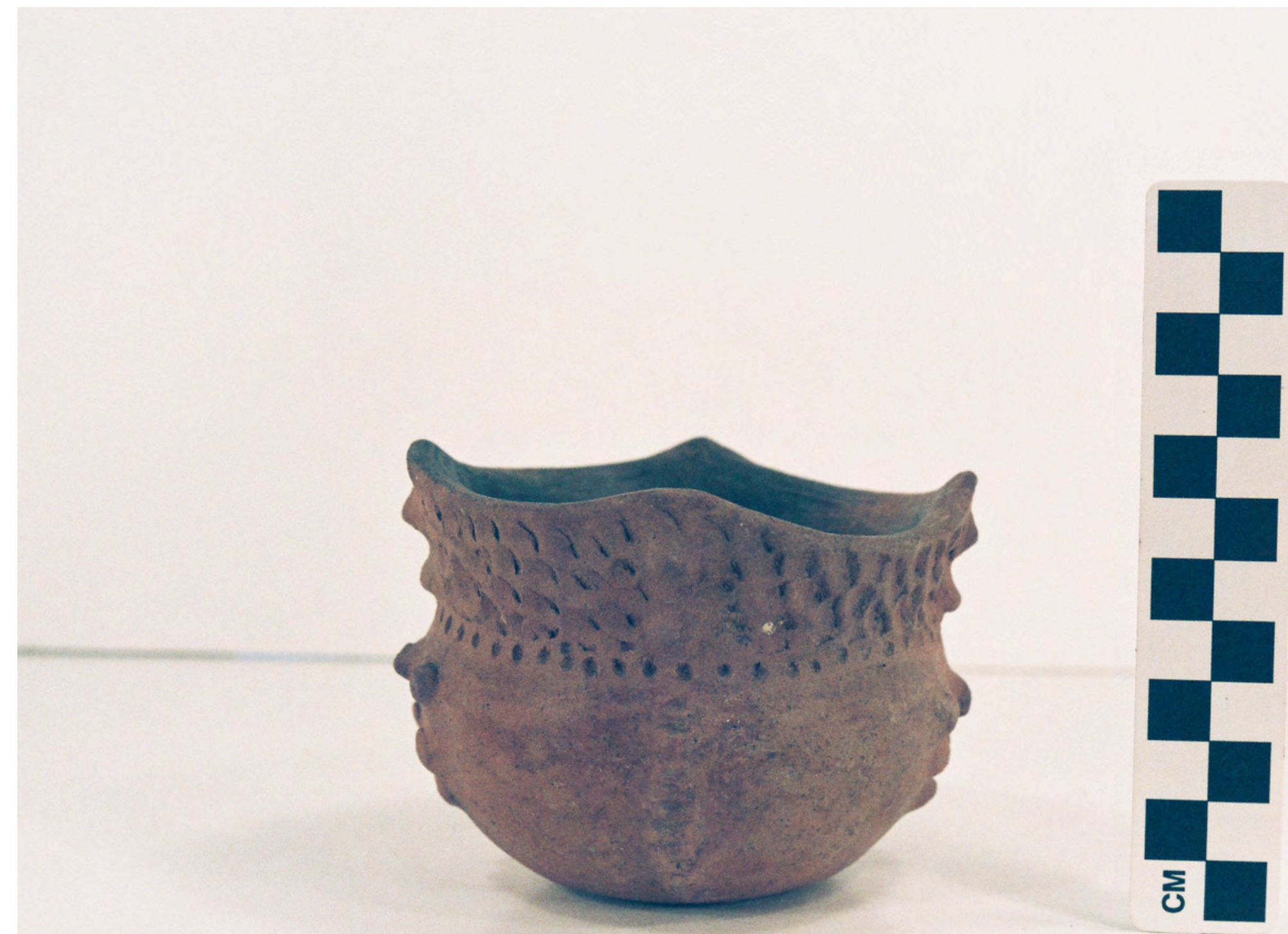

Figure $3 b$ 


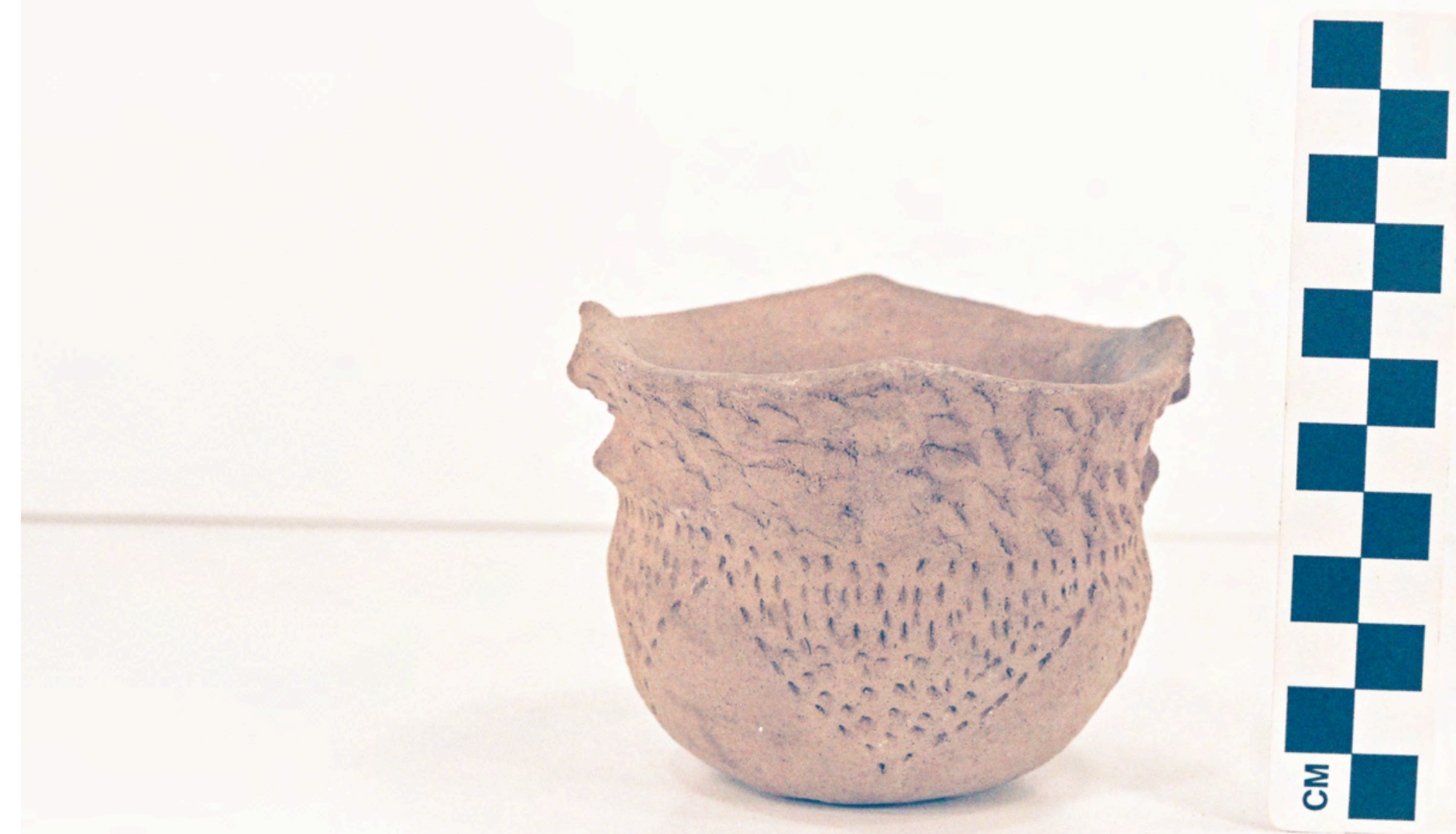

Figure $3 \mathrm{c}$ 


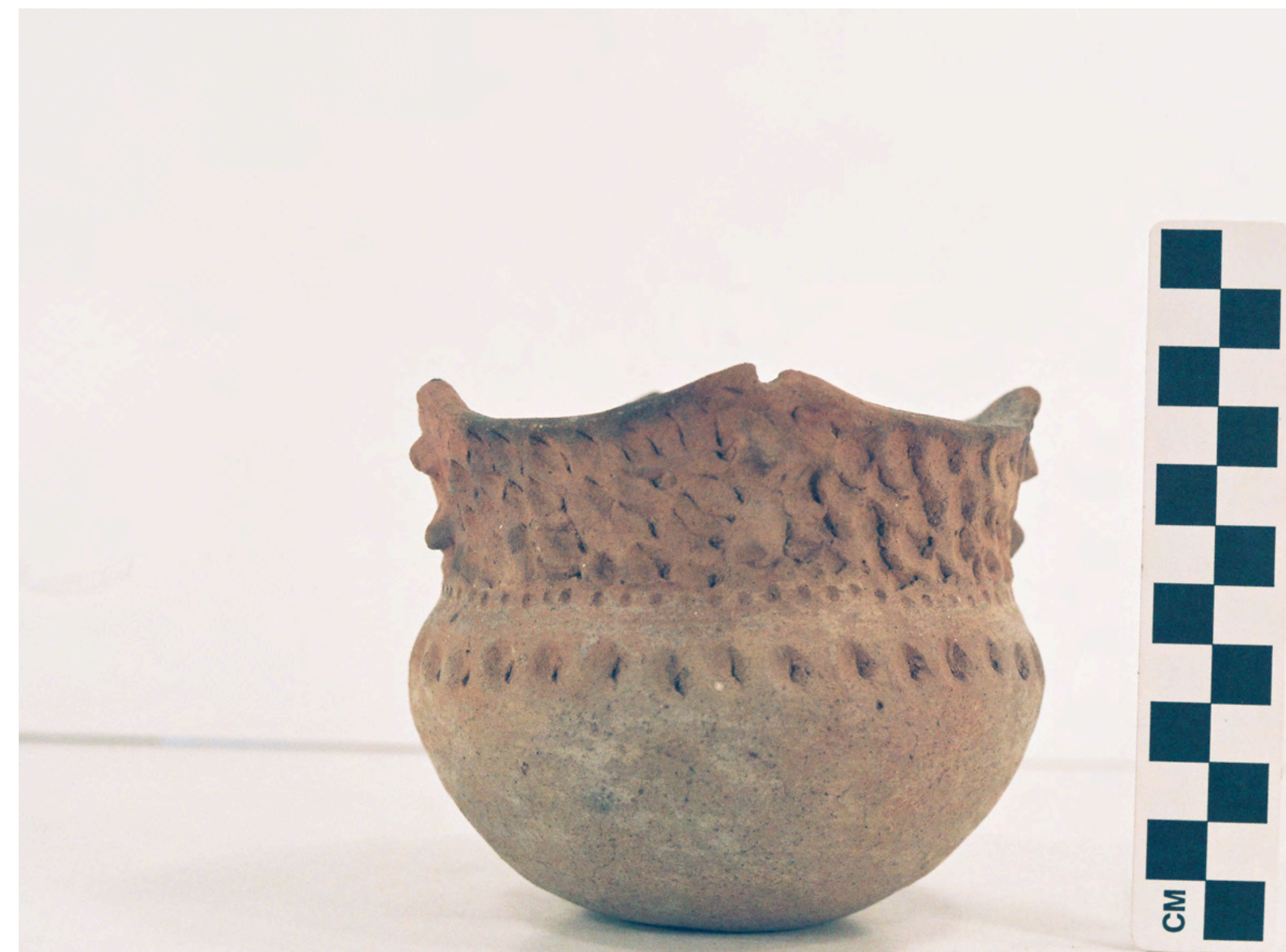

Figure 3d 


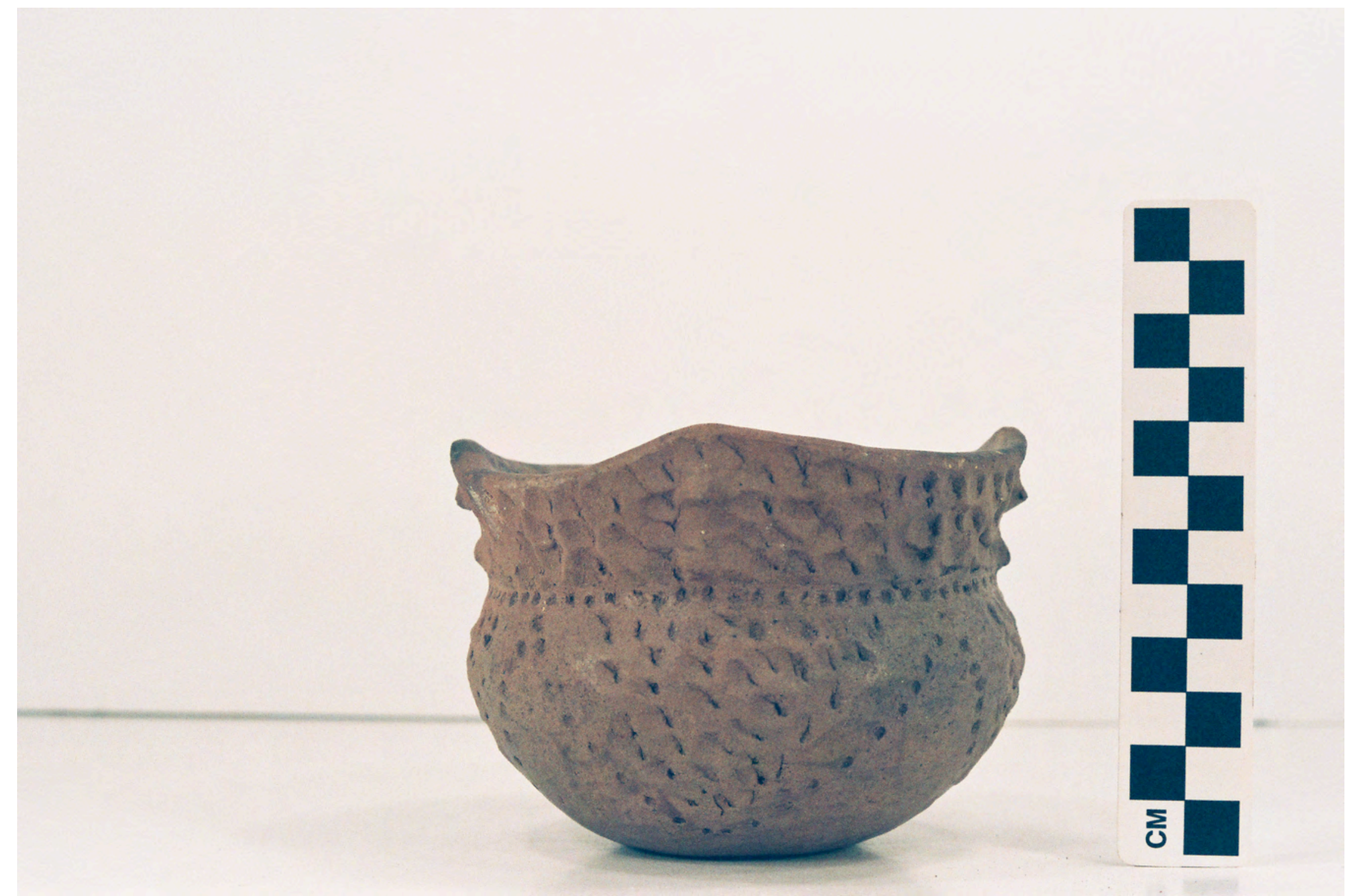

Figure 3e 


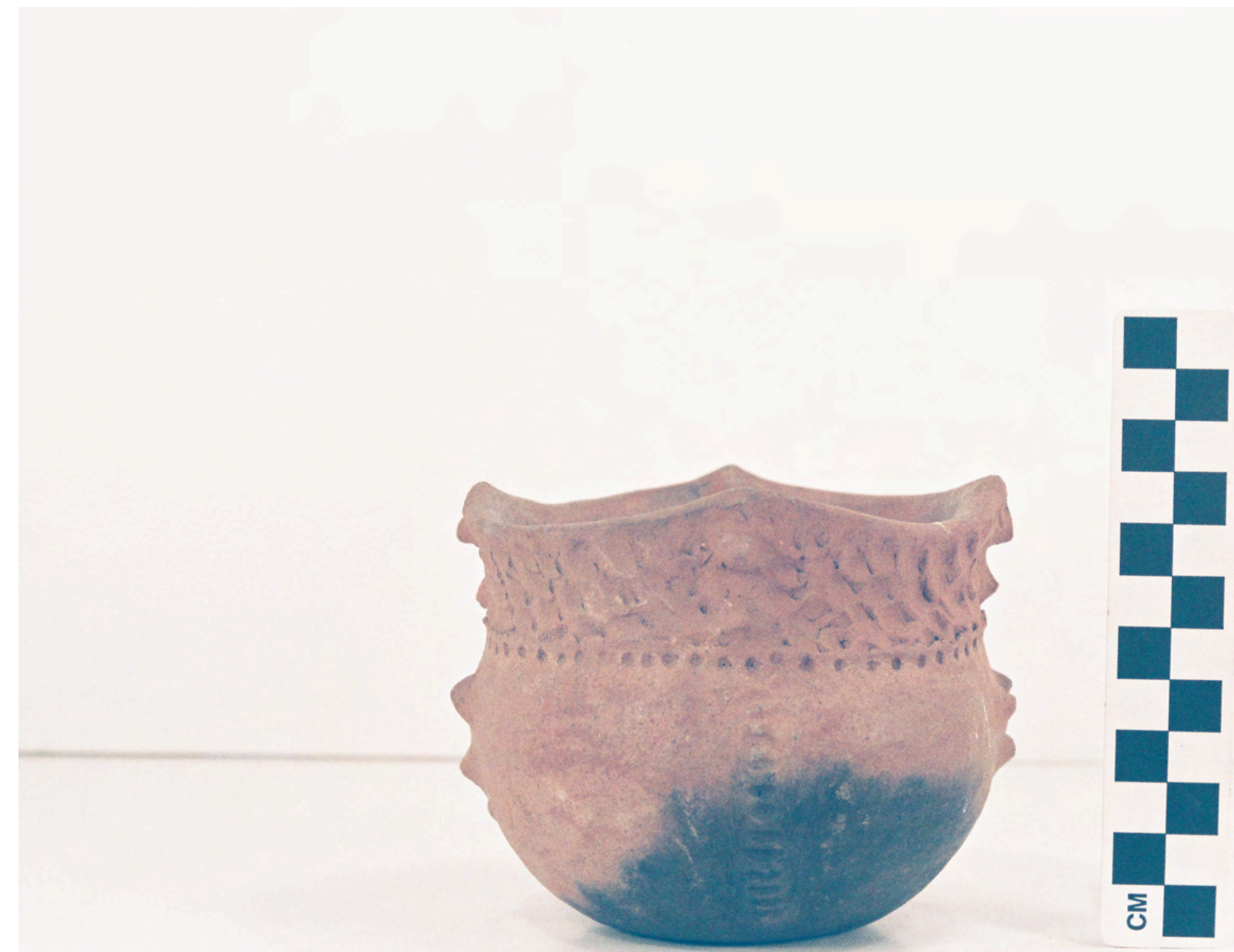

Figure $3 \mathrm{f}$ 


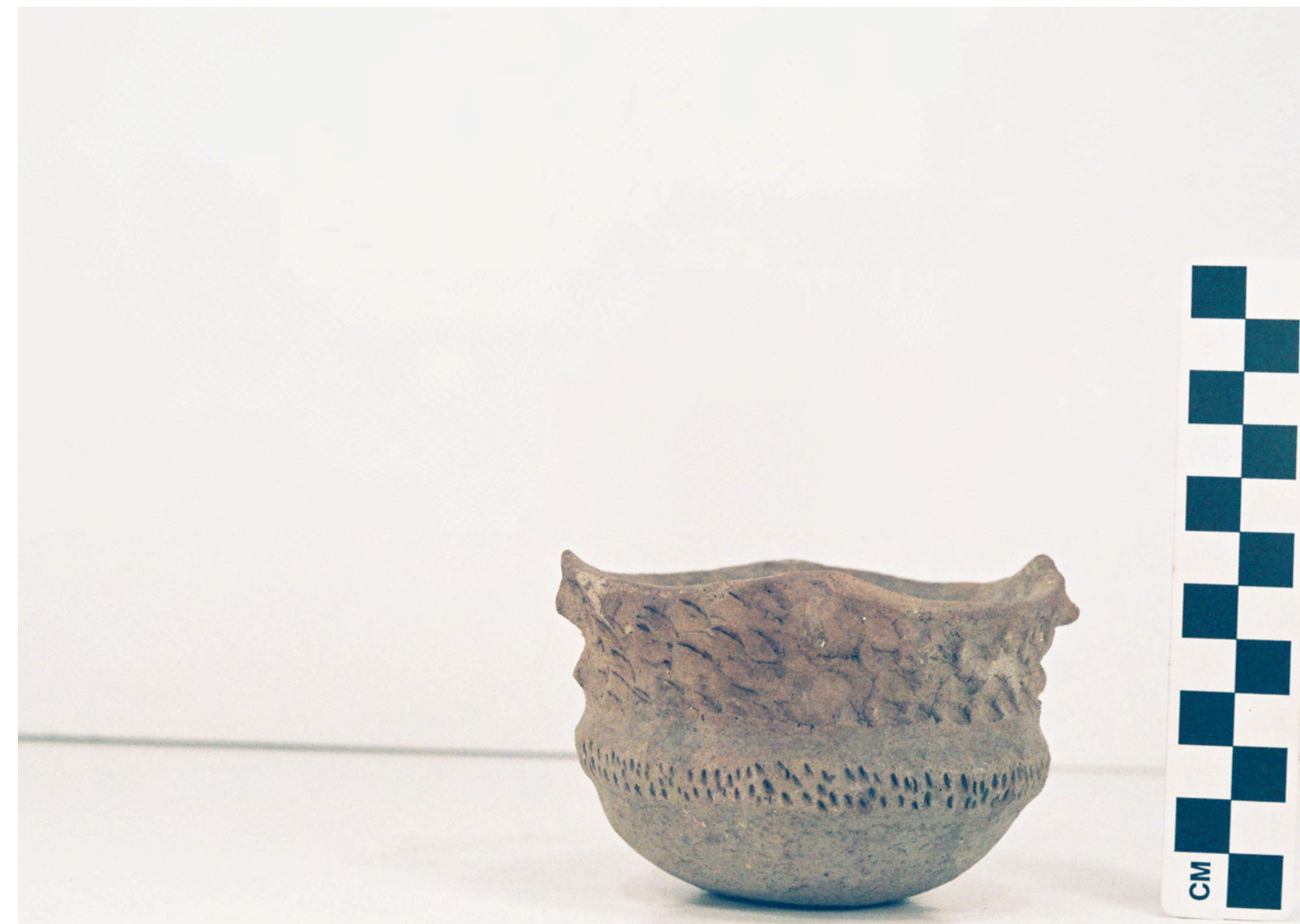

Figure 3g 


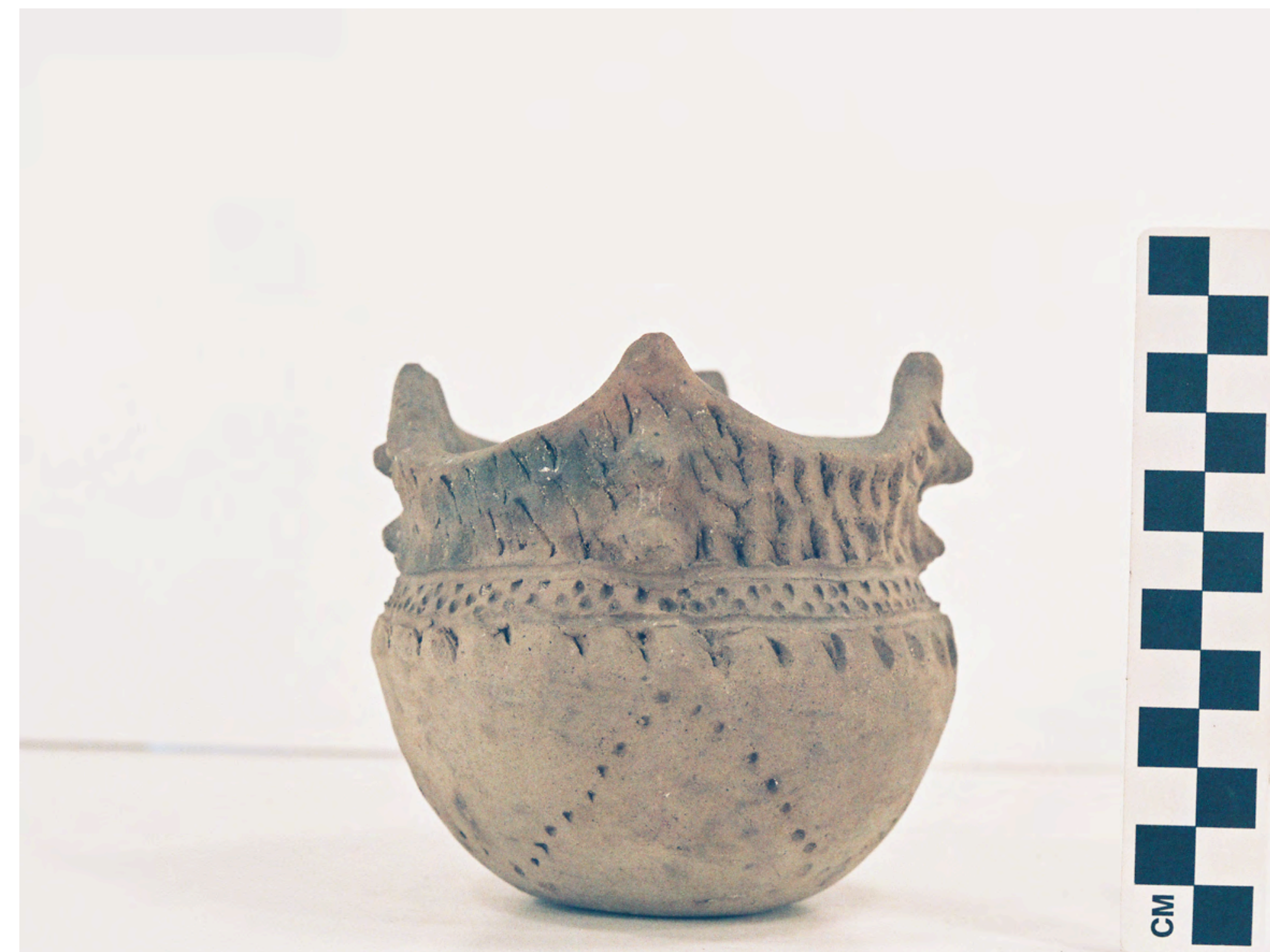

Figure $3 \mathrm{~h}$ 


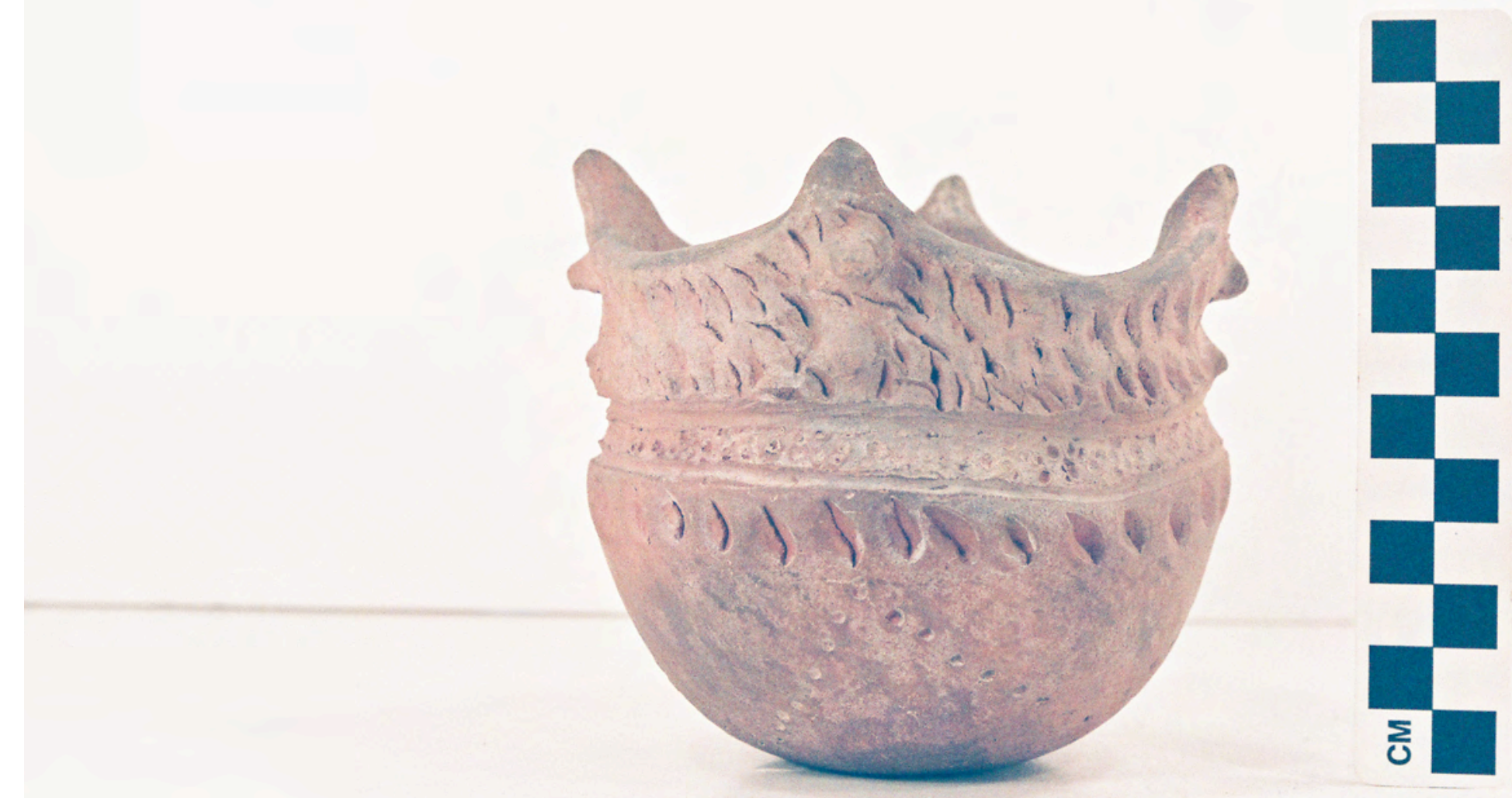

Figure $3 \mathrm{i}$ 


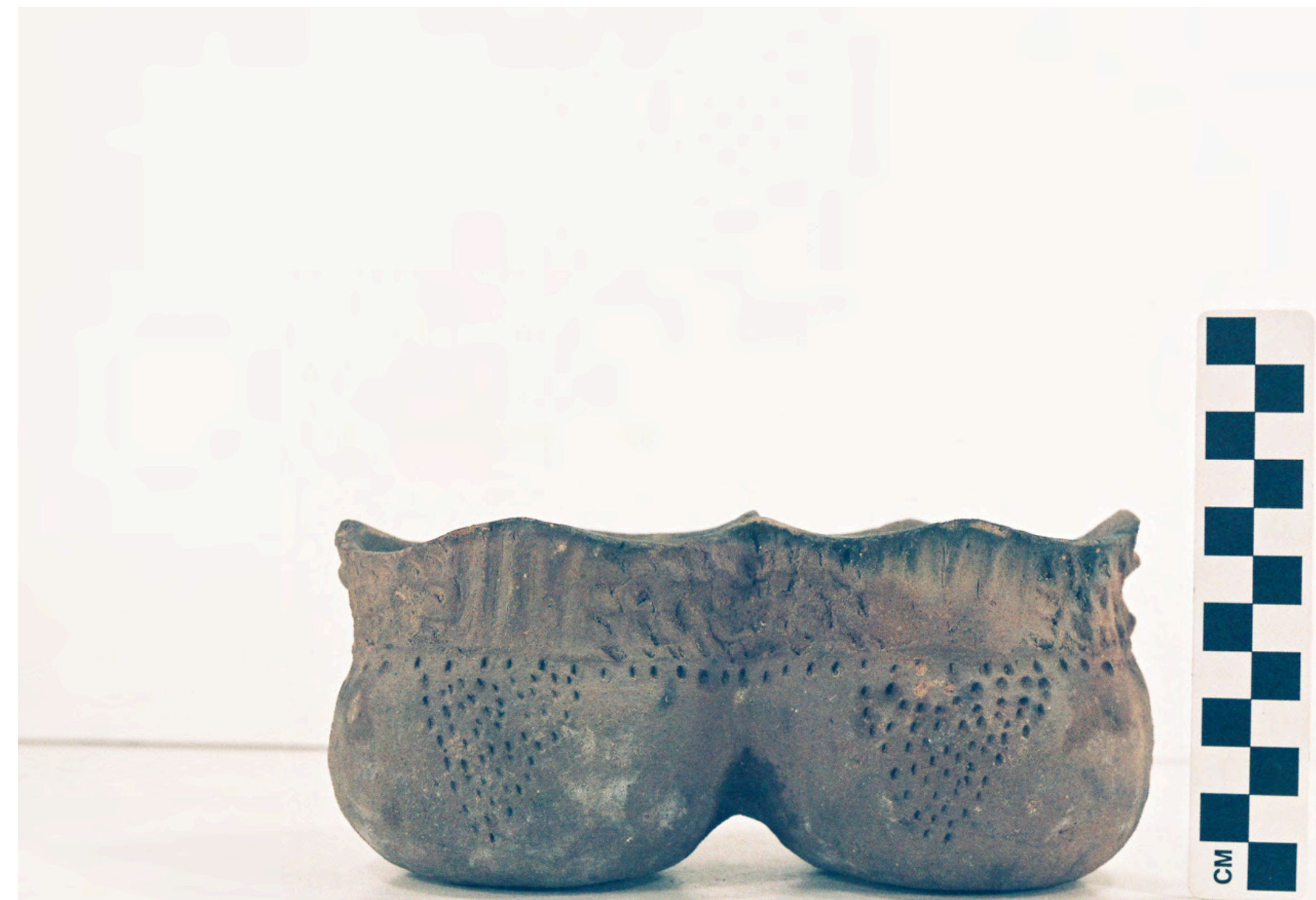

Figure $3 \mathrm{j}$ 

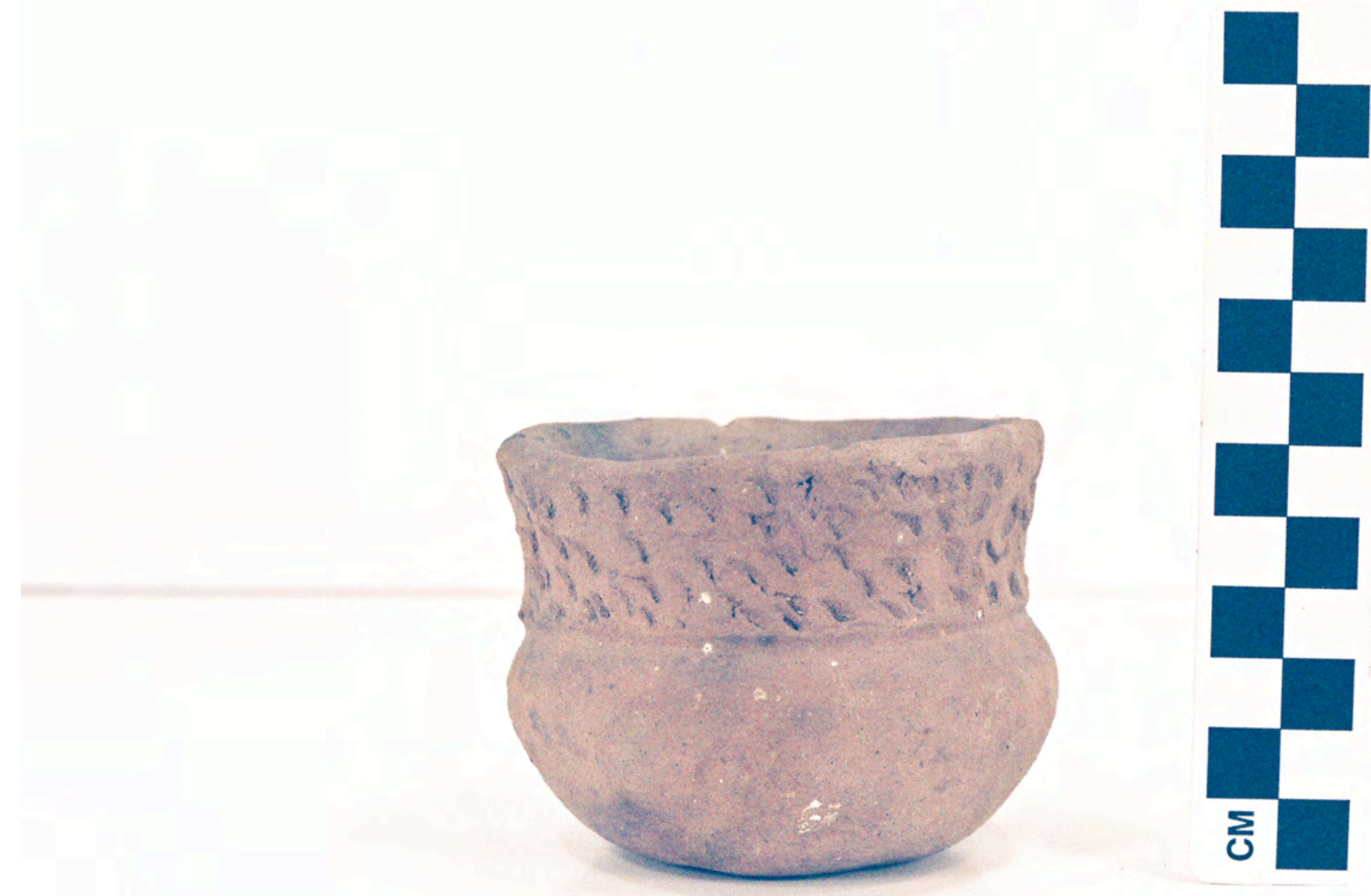

Figure 4a 


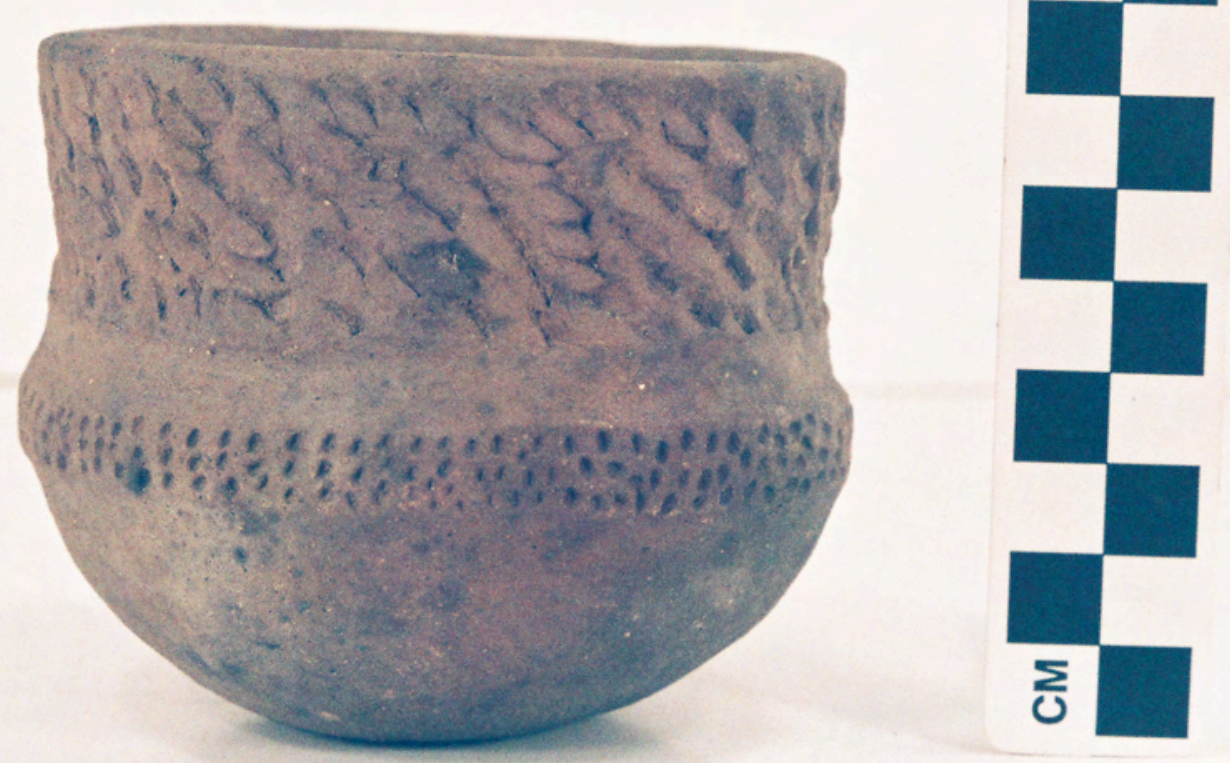

Figure $4 b$ 


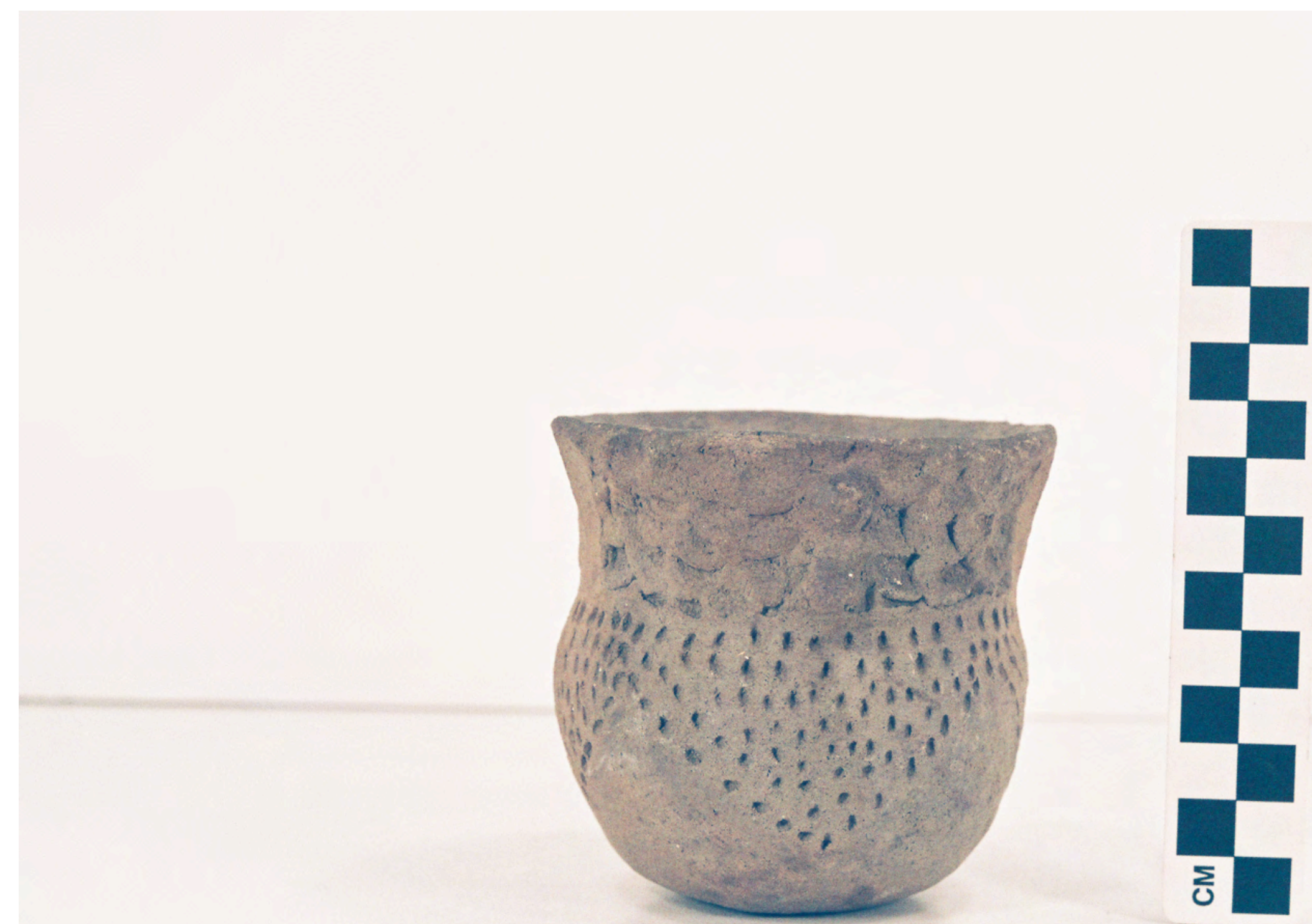

Figure 4c 


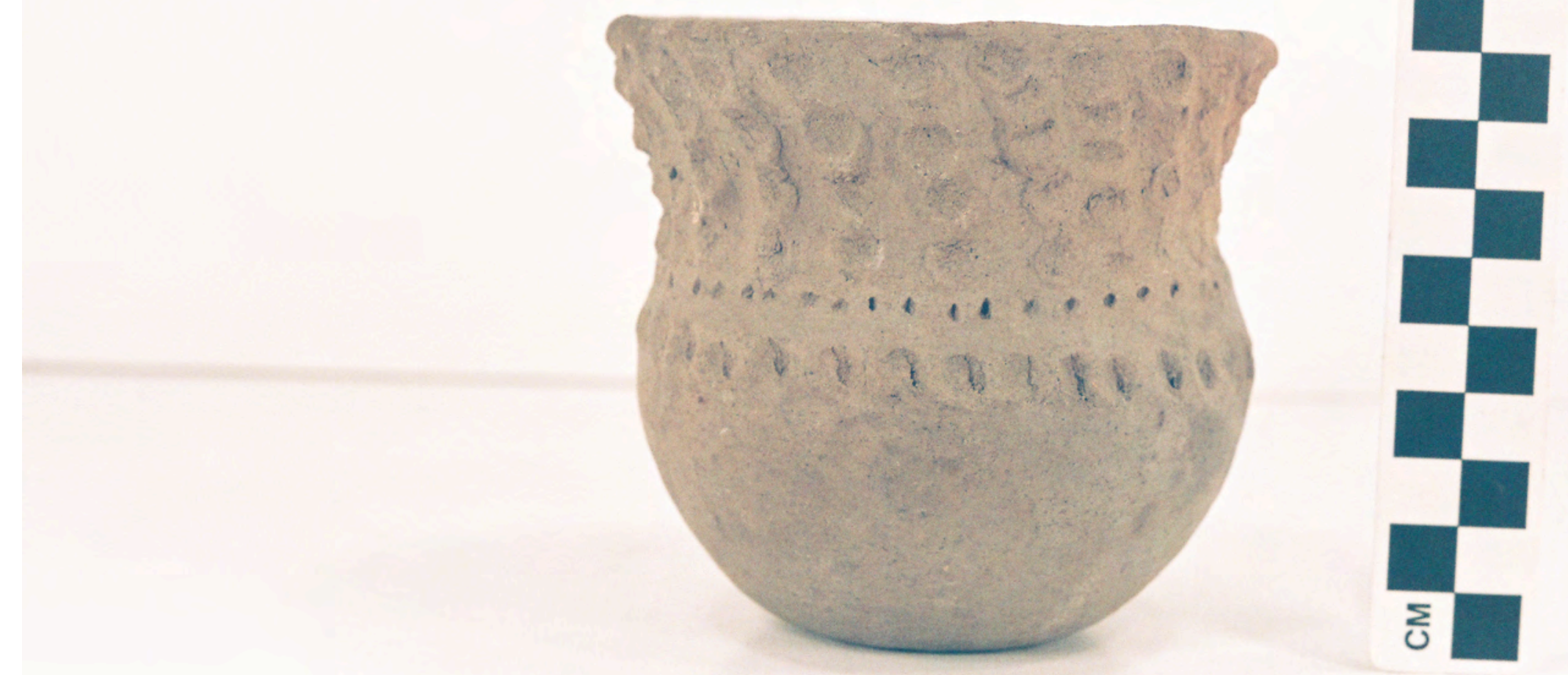

Figure 4d 


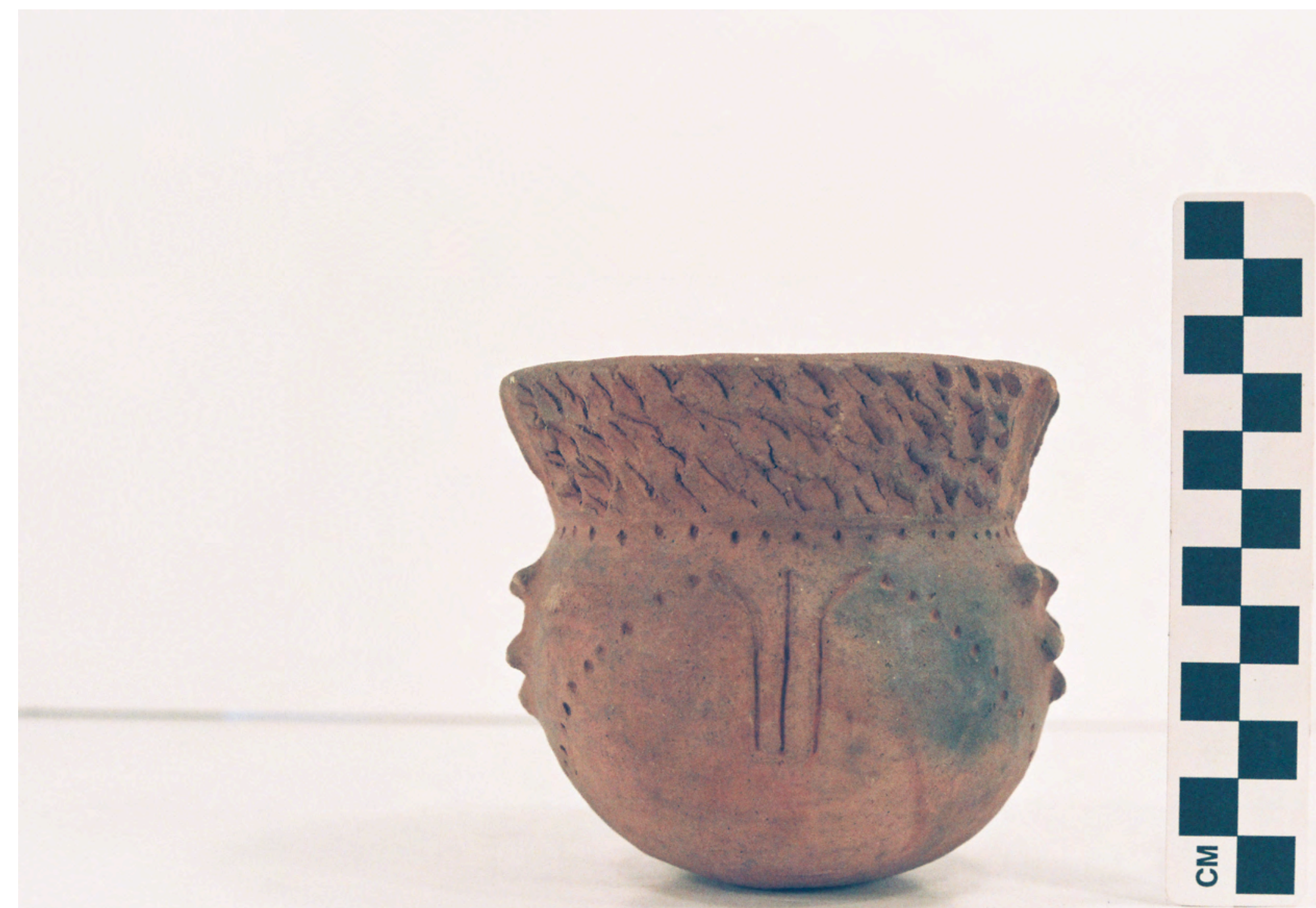

Figure 4e 


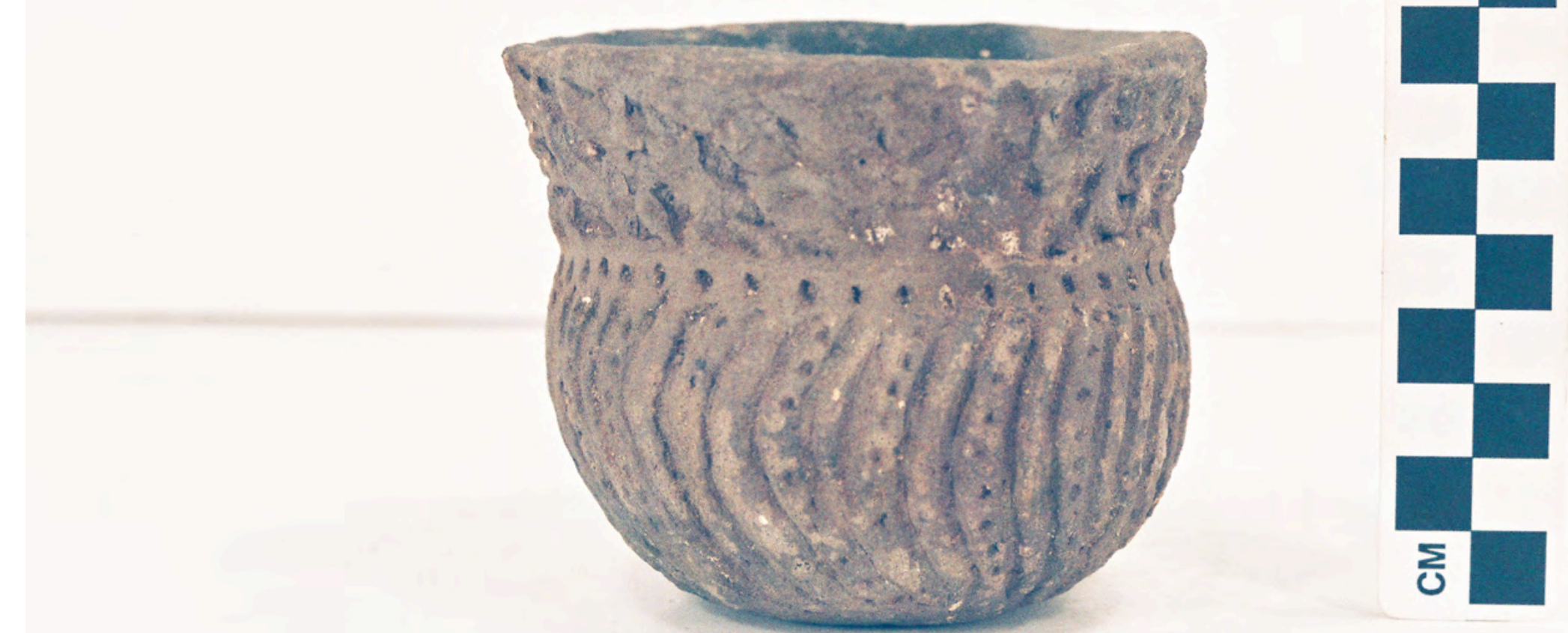

Figure 4f 


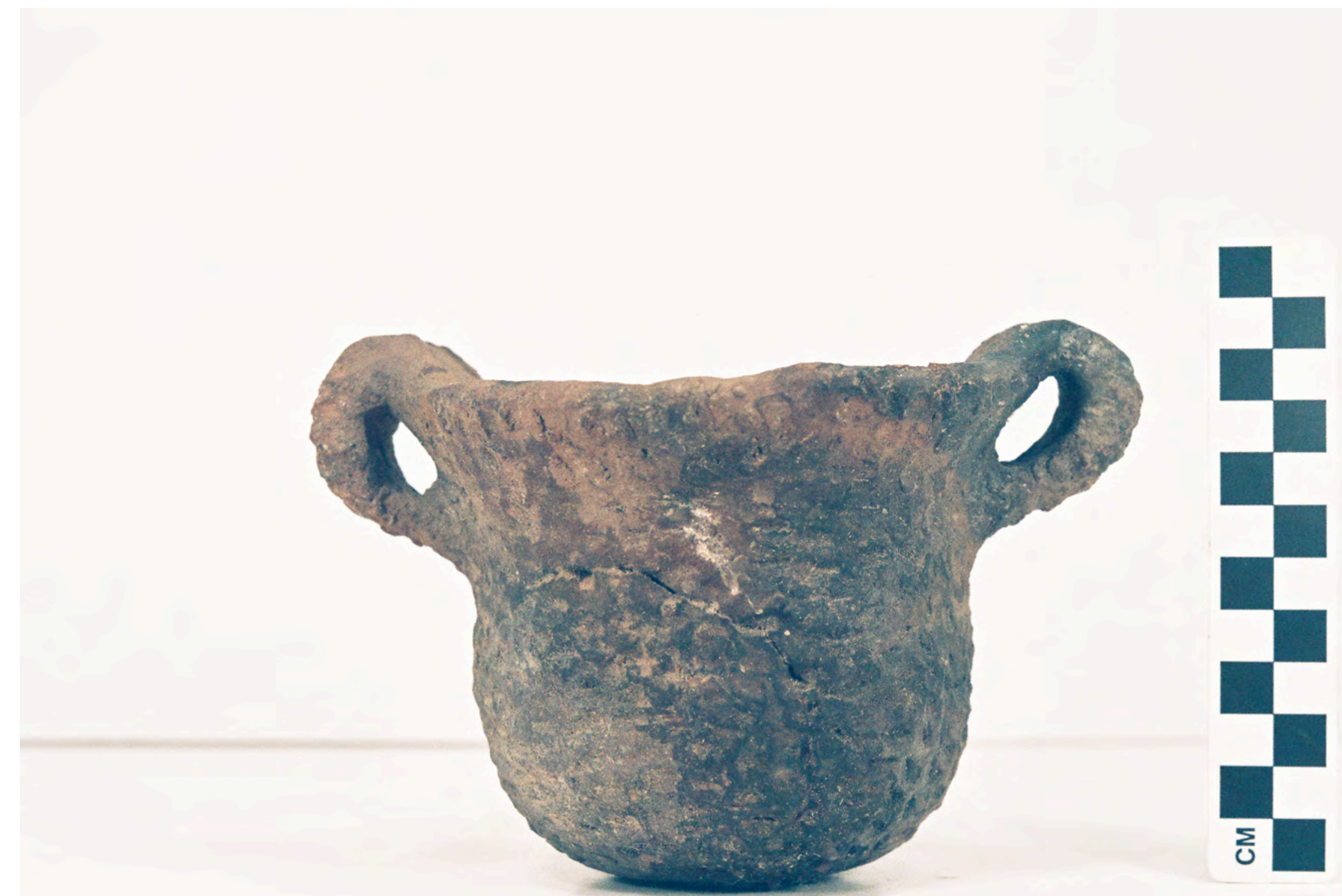

Figure 5a 


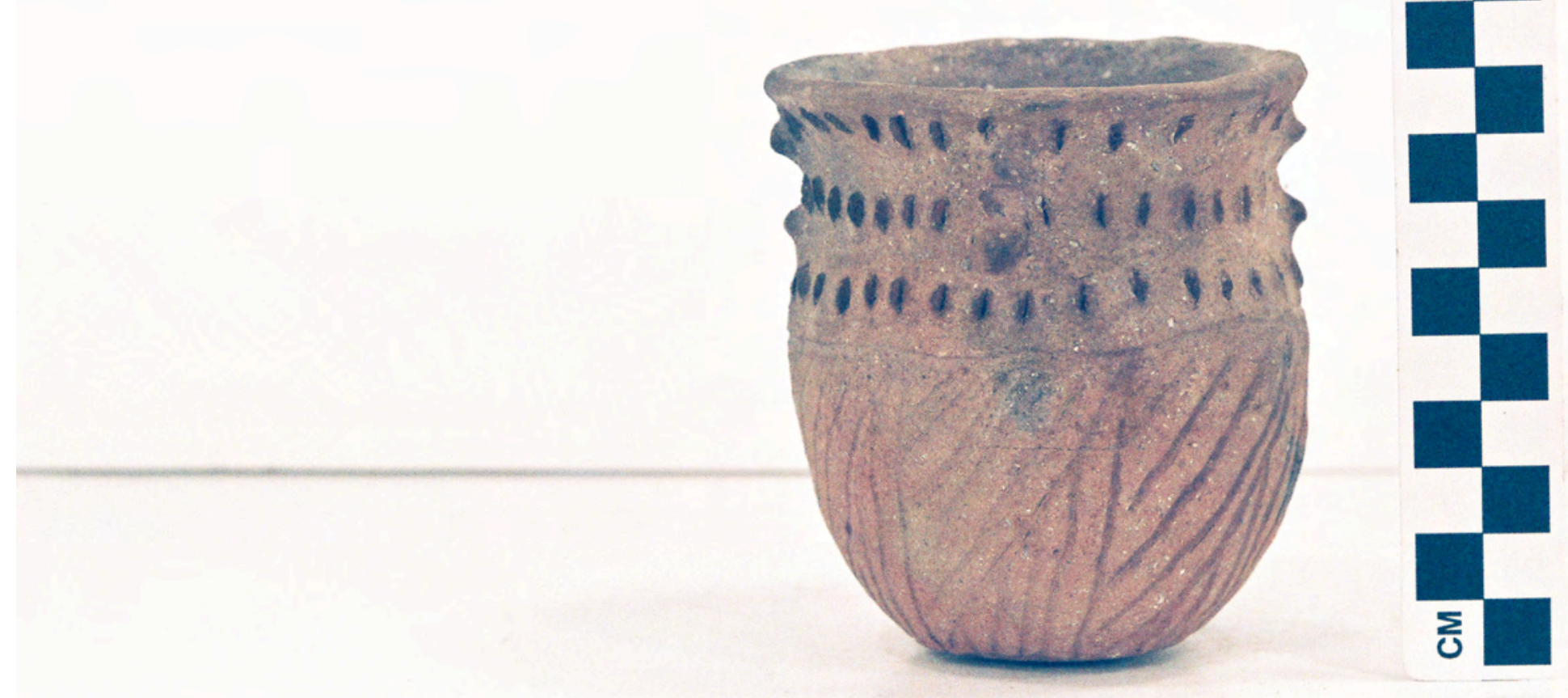

Figure $5 b$ 


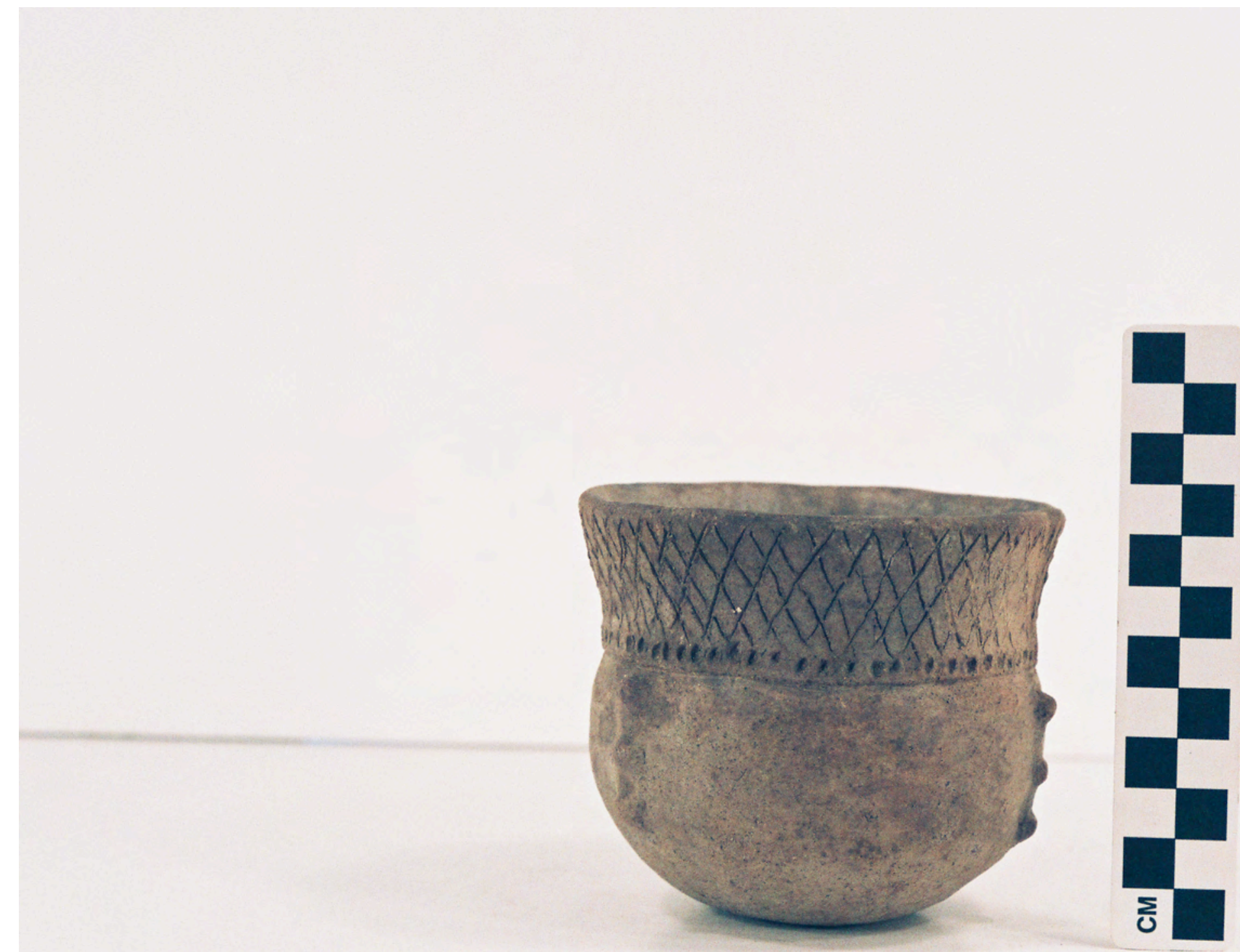

Figure 5c 


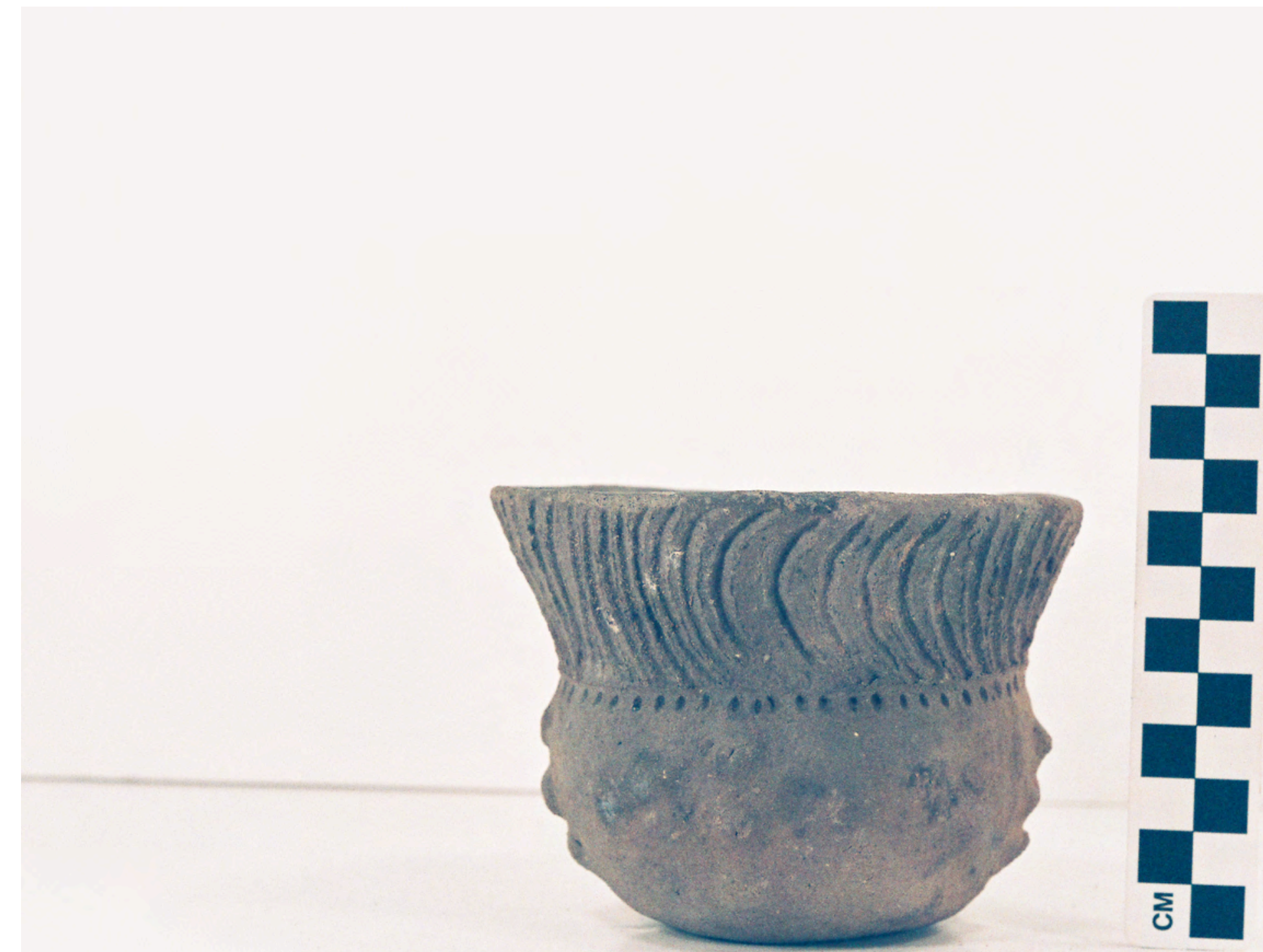

Figure 5d 


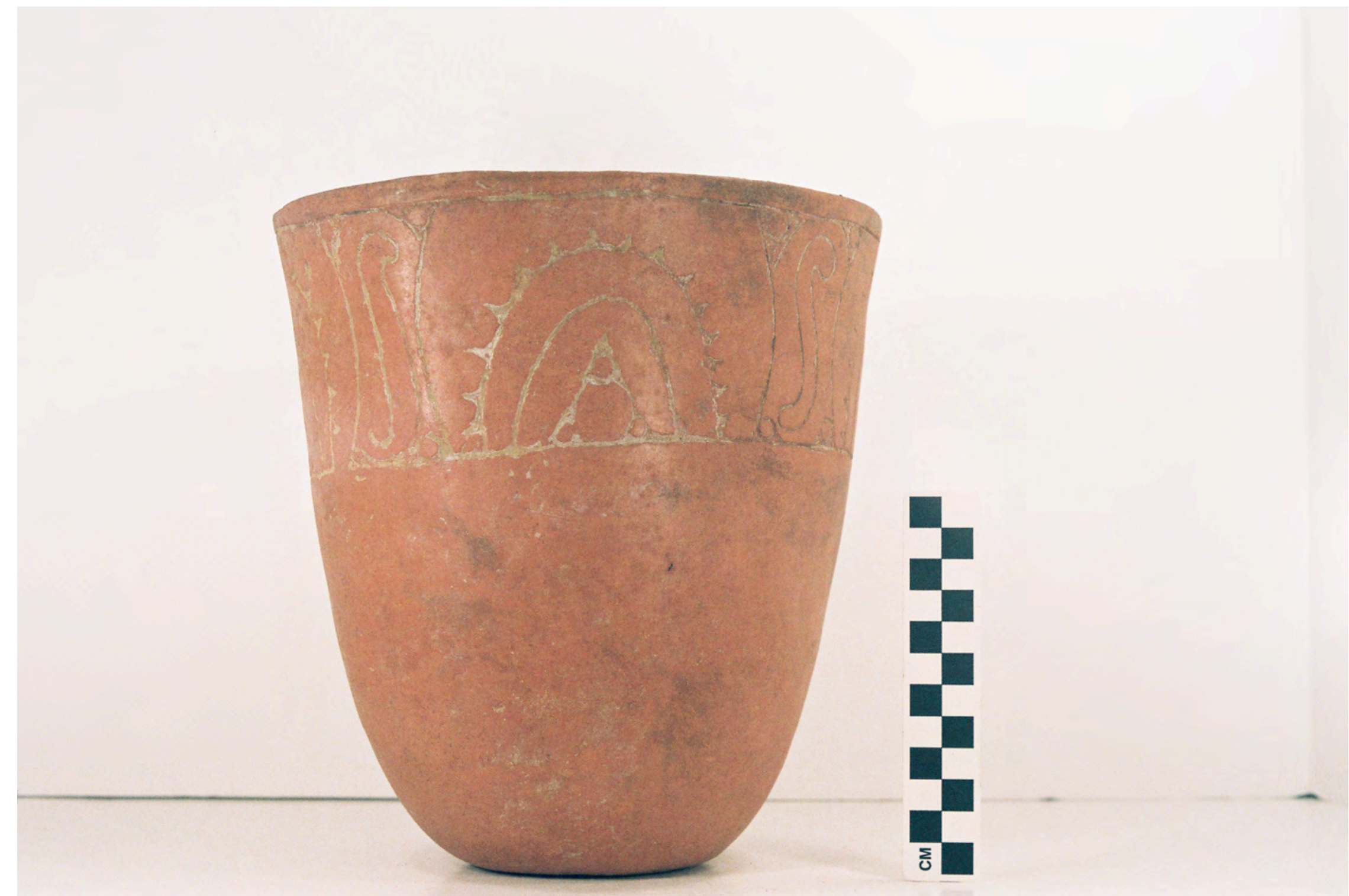

Figure 6a 


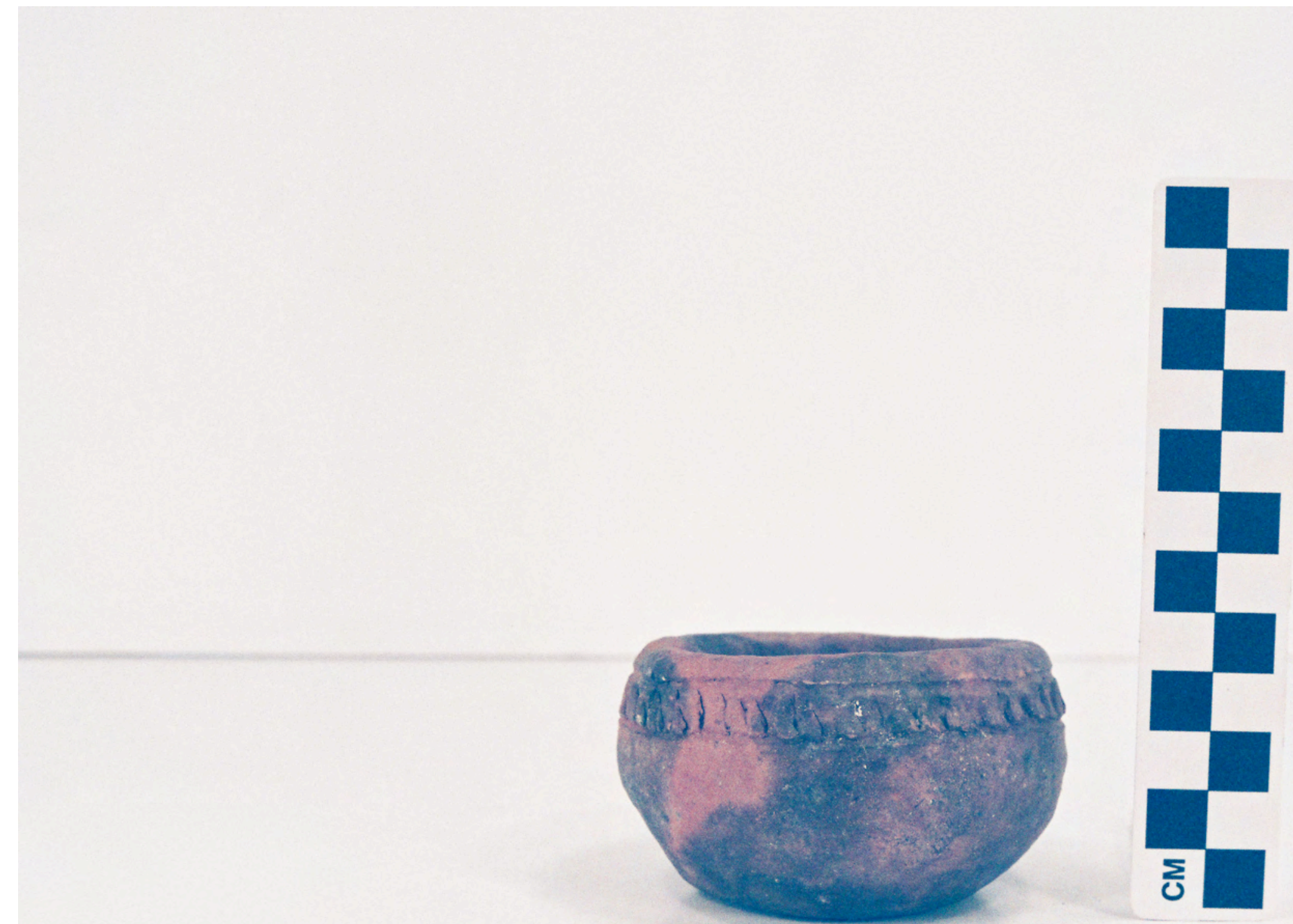

Figure $6 \mathrm{~b}$ 


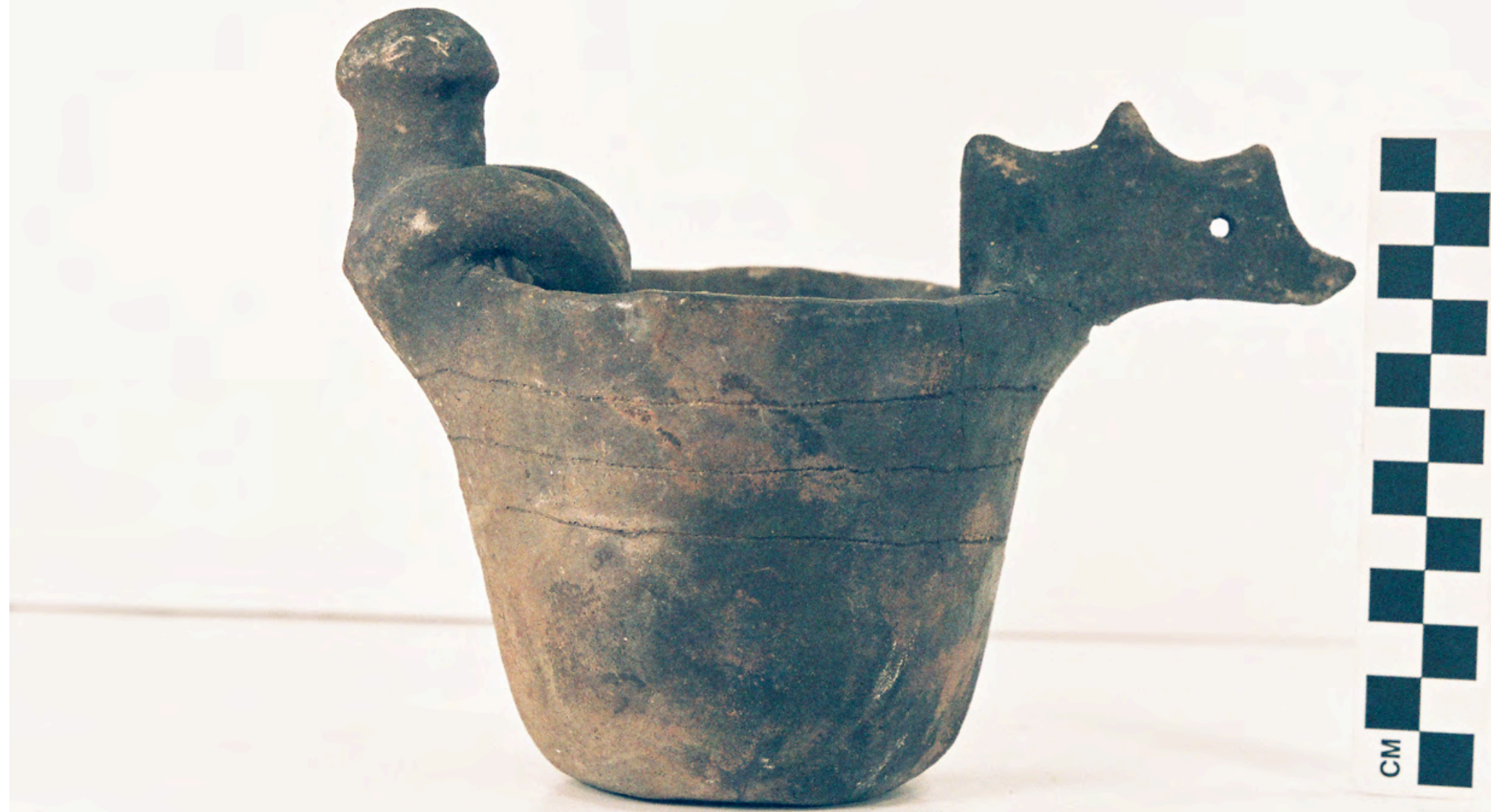

Figure 6c 


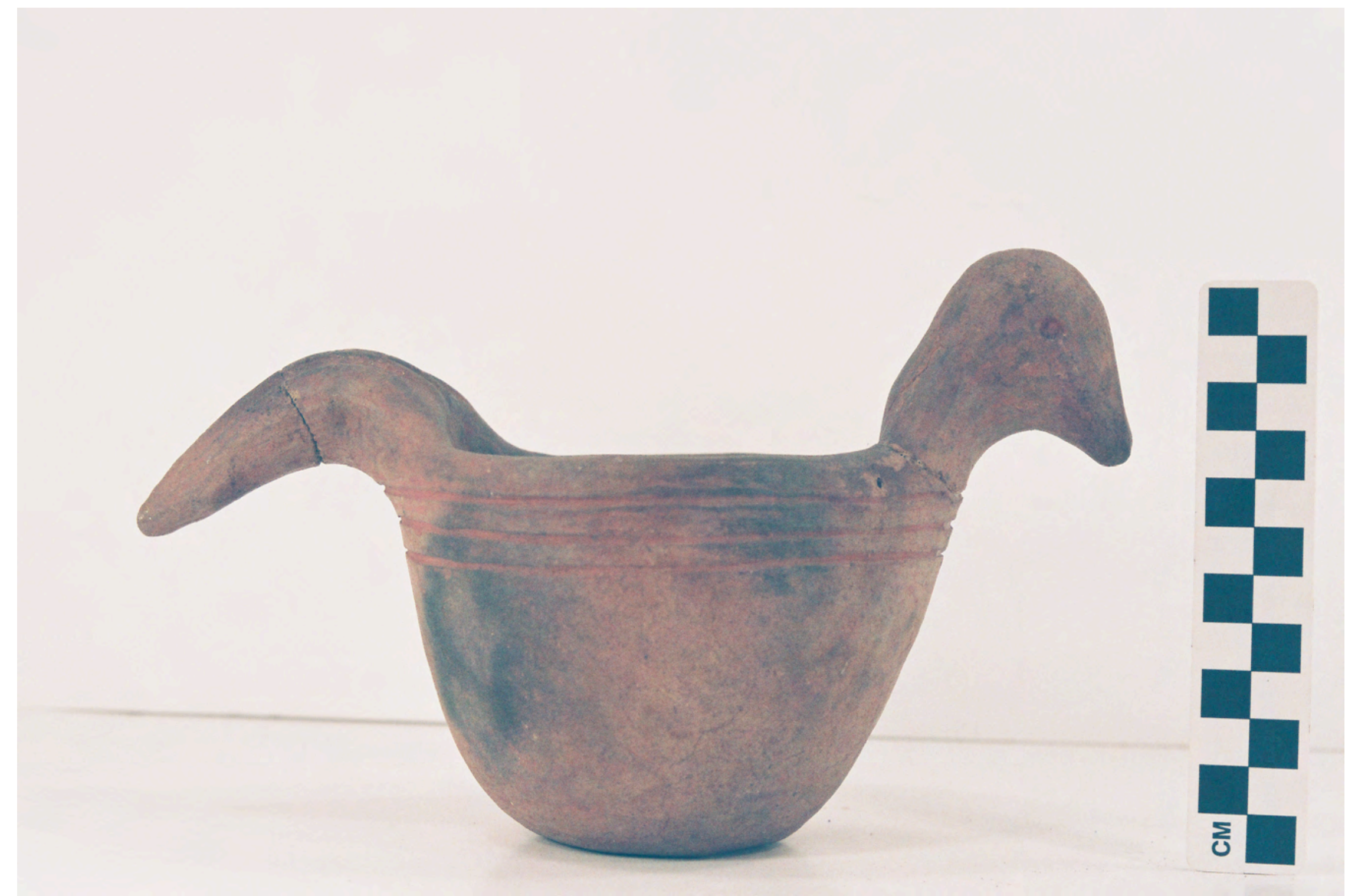

Figure 6d 


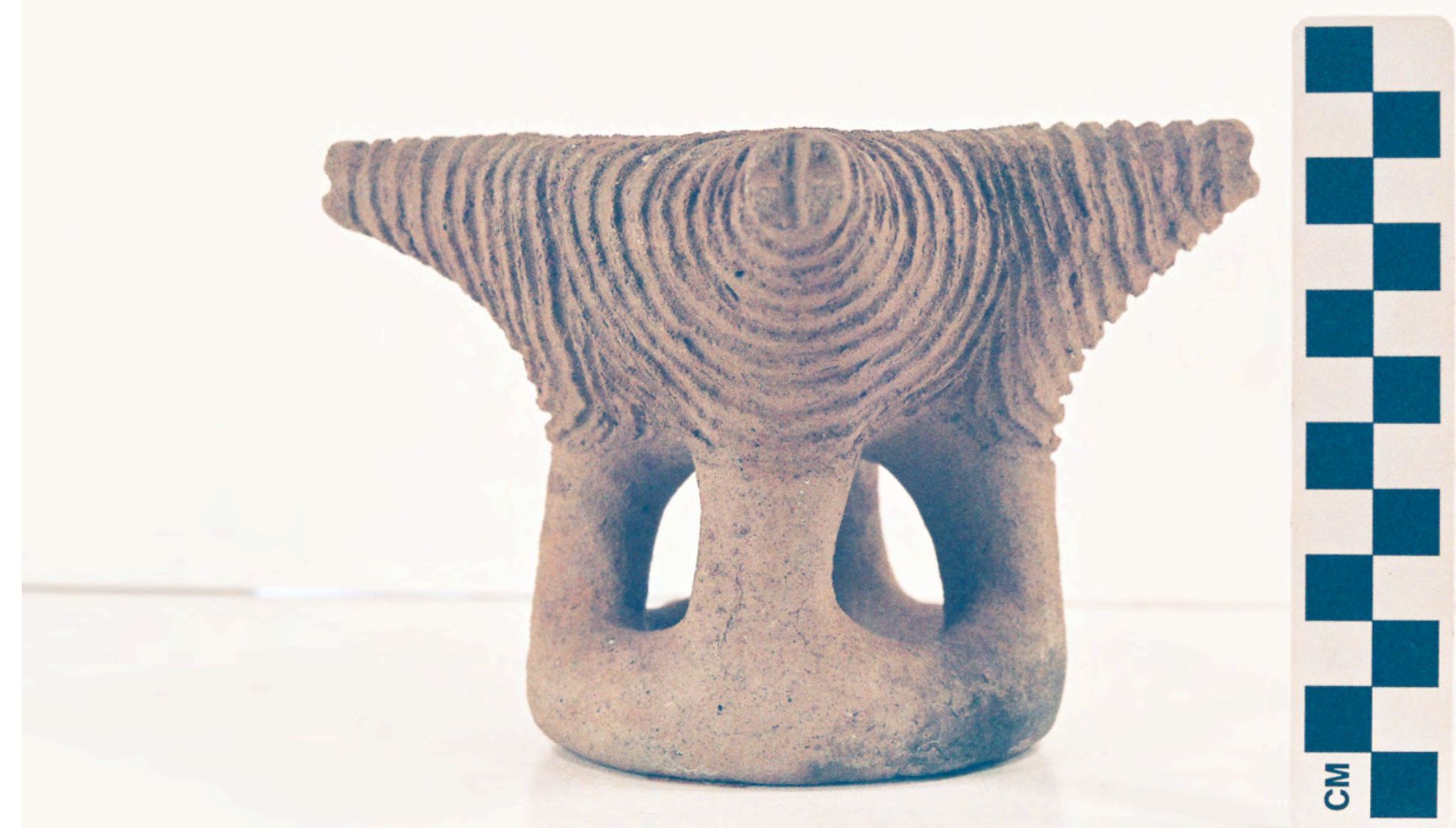

Figure $7 \mathrm{a}$ 


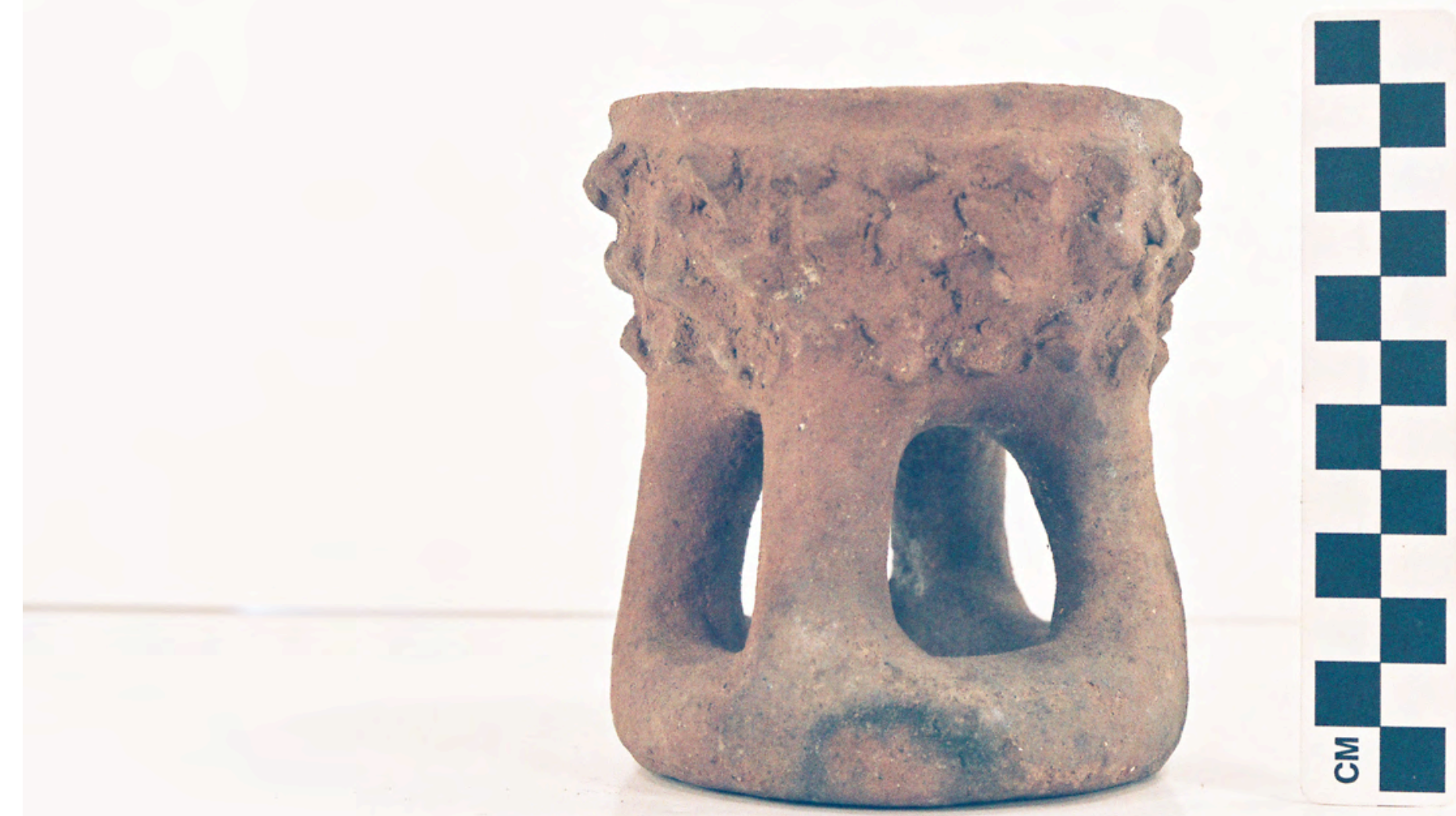

Figure 7b 


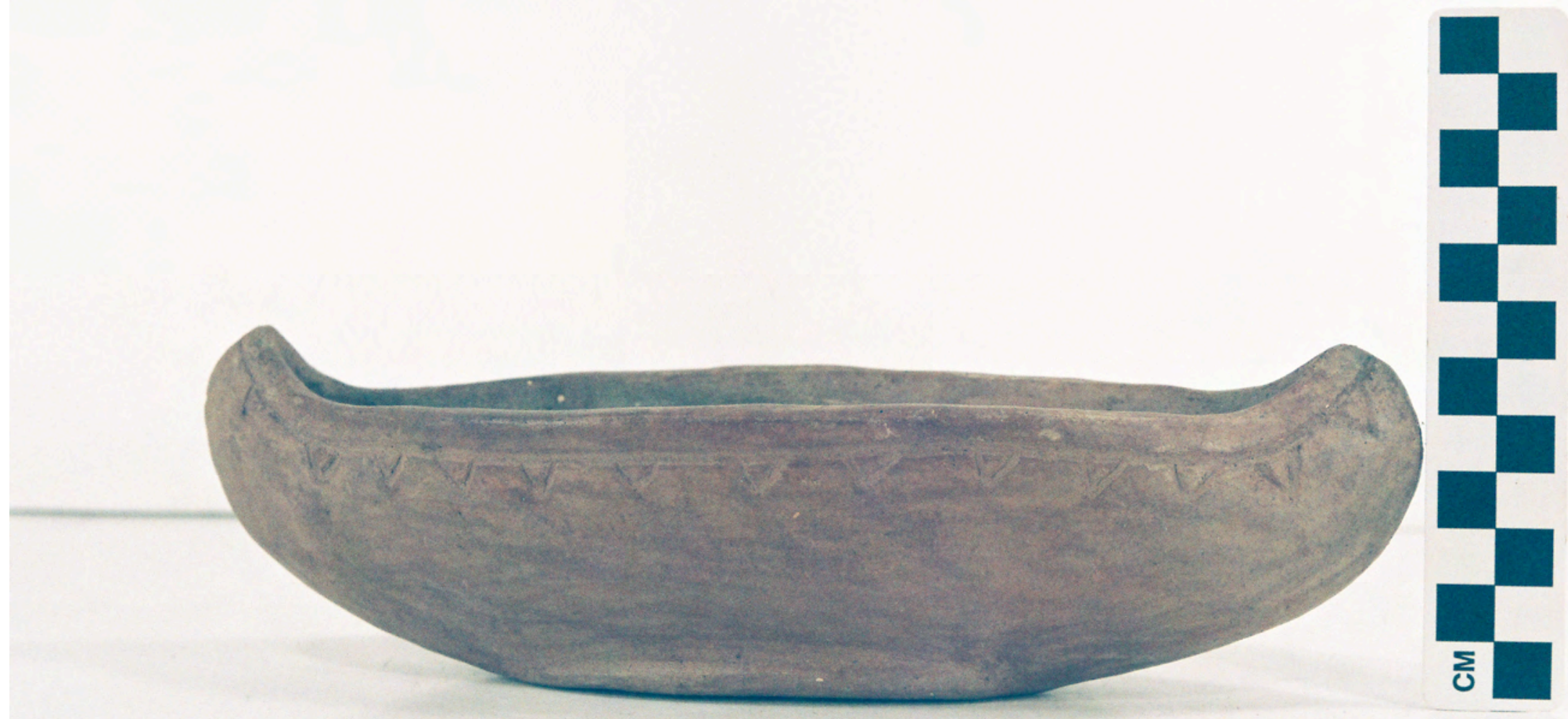

Figure 7c 


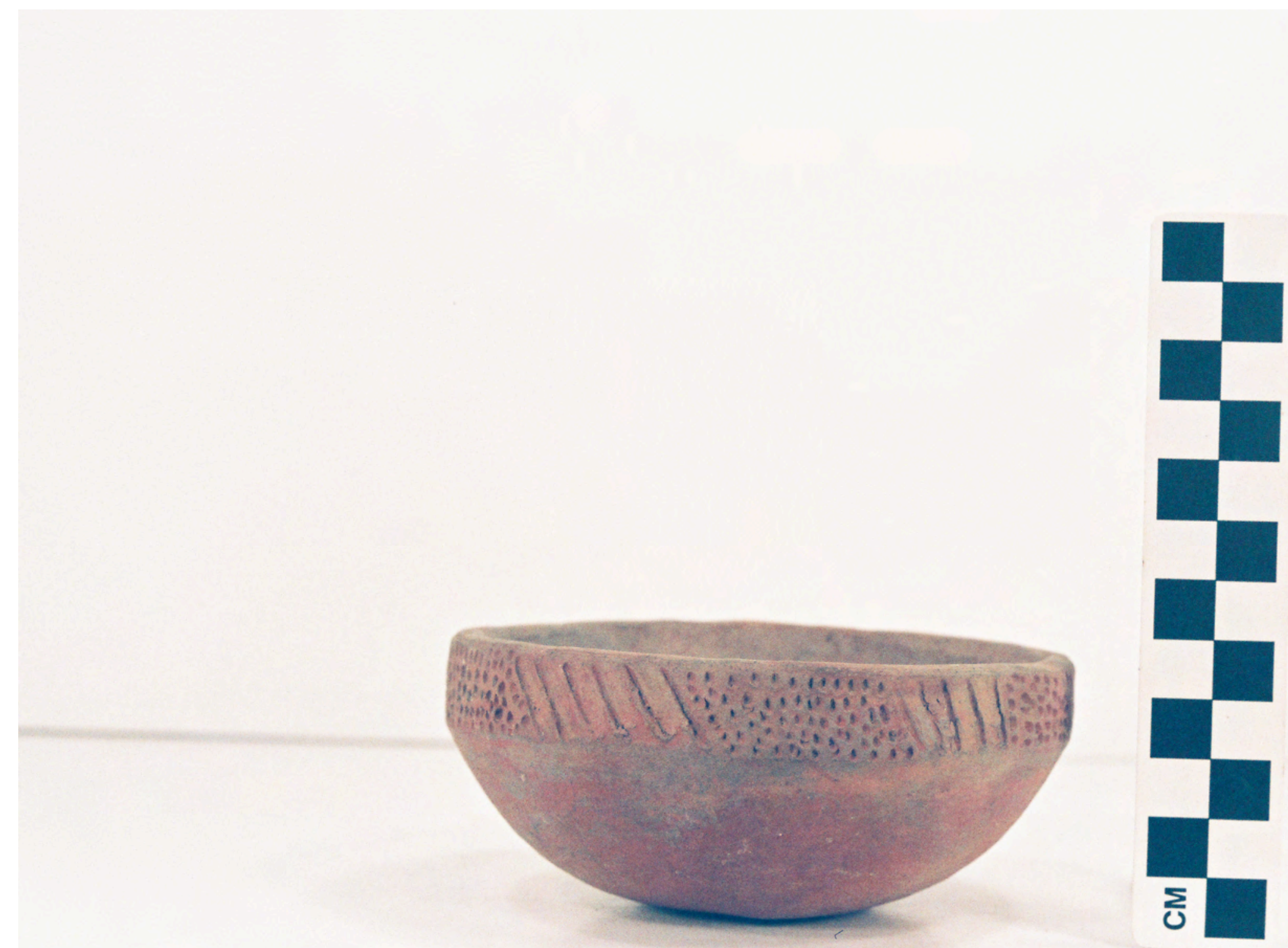

Figure 8a 


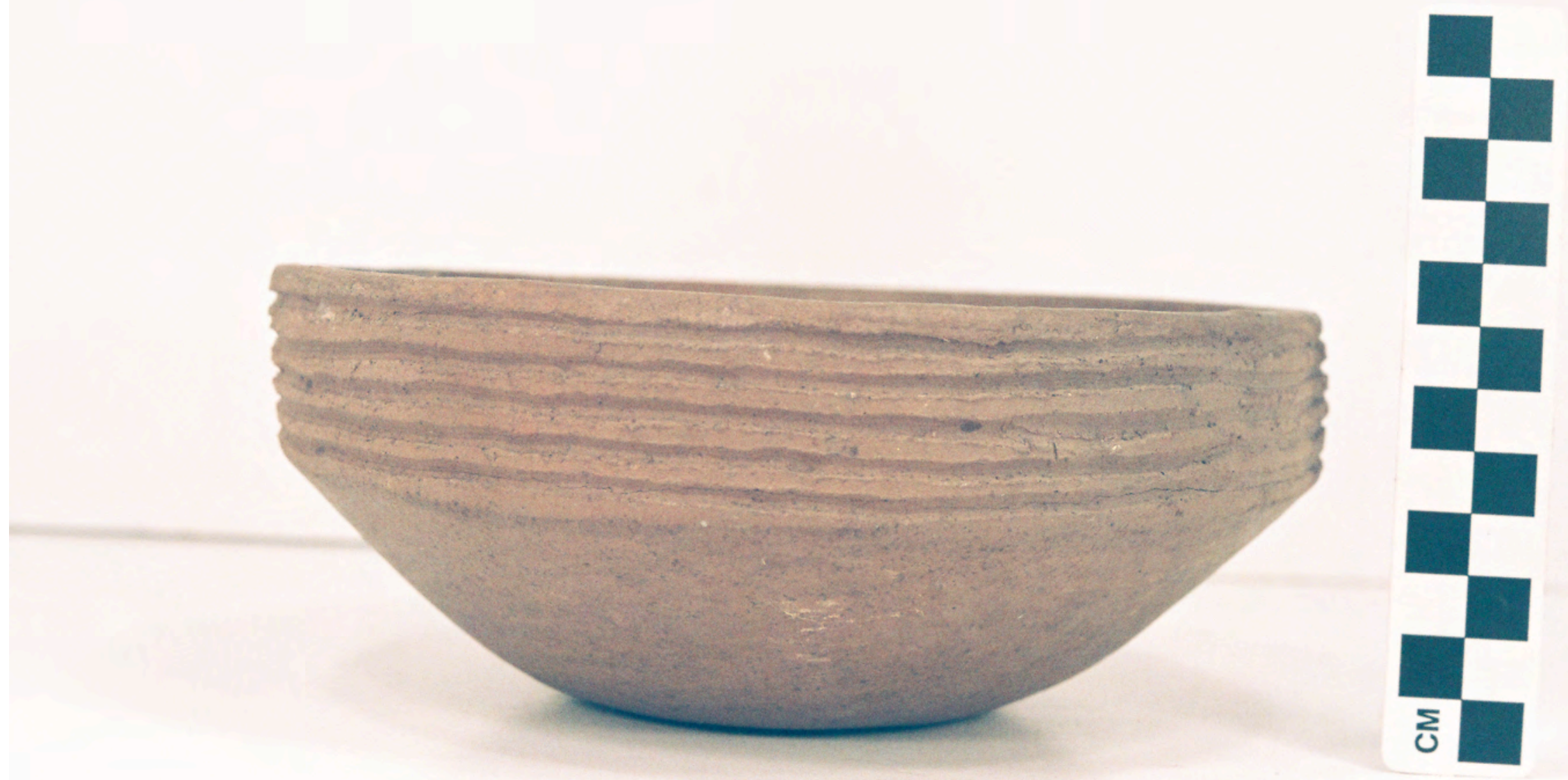

Figure $8 b$ 


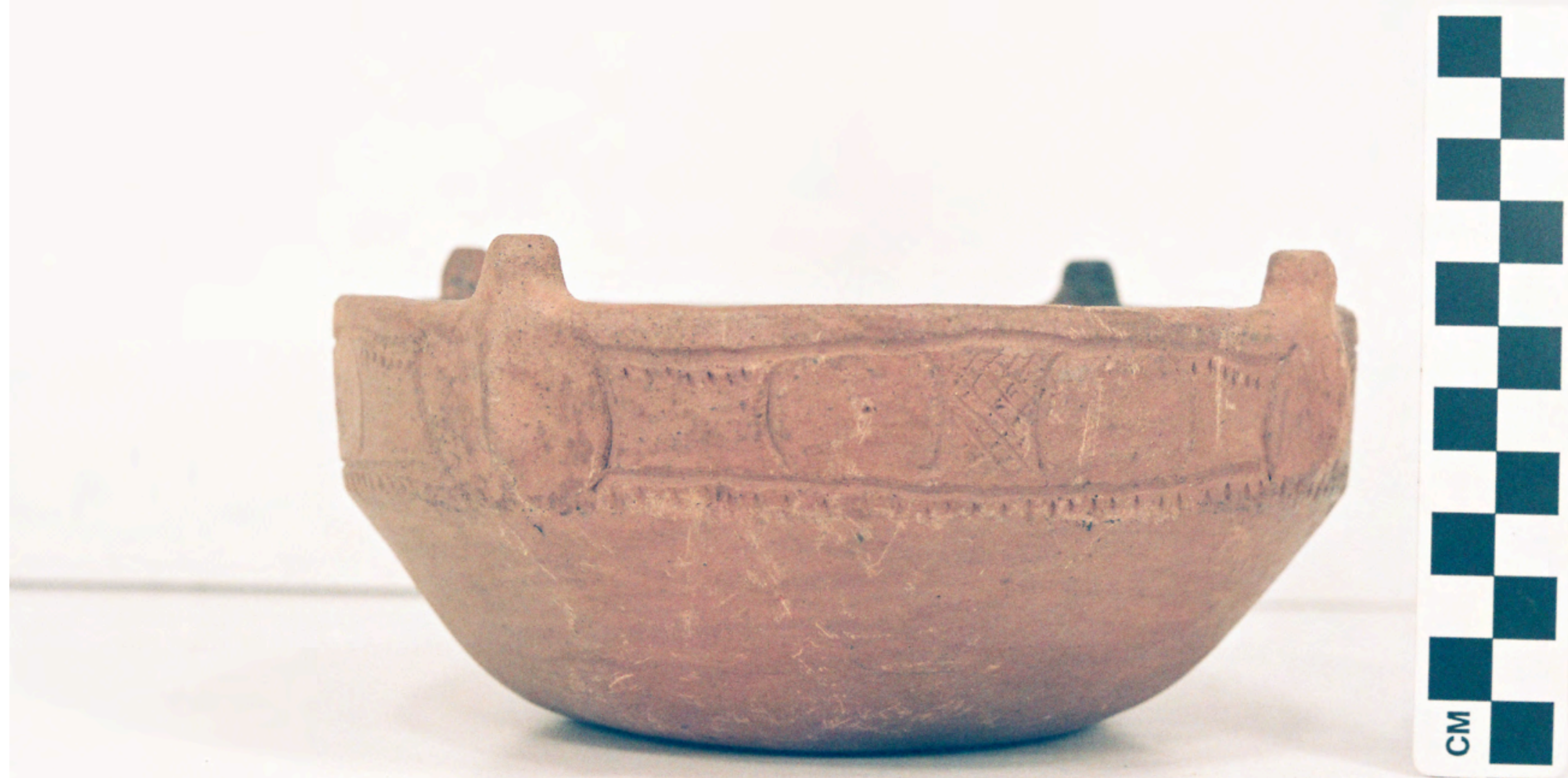

Figure 8c 


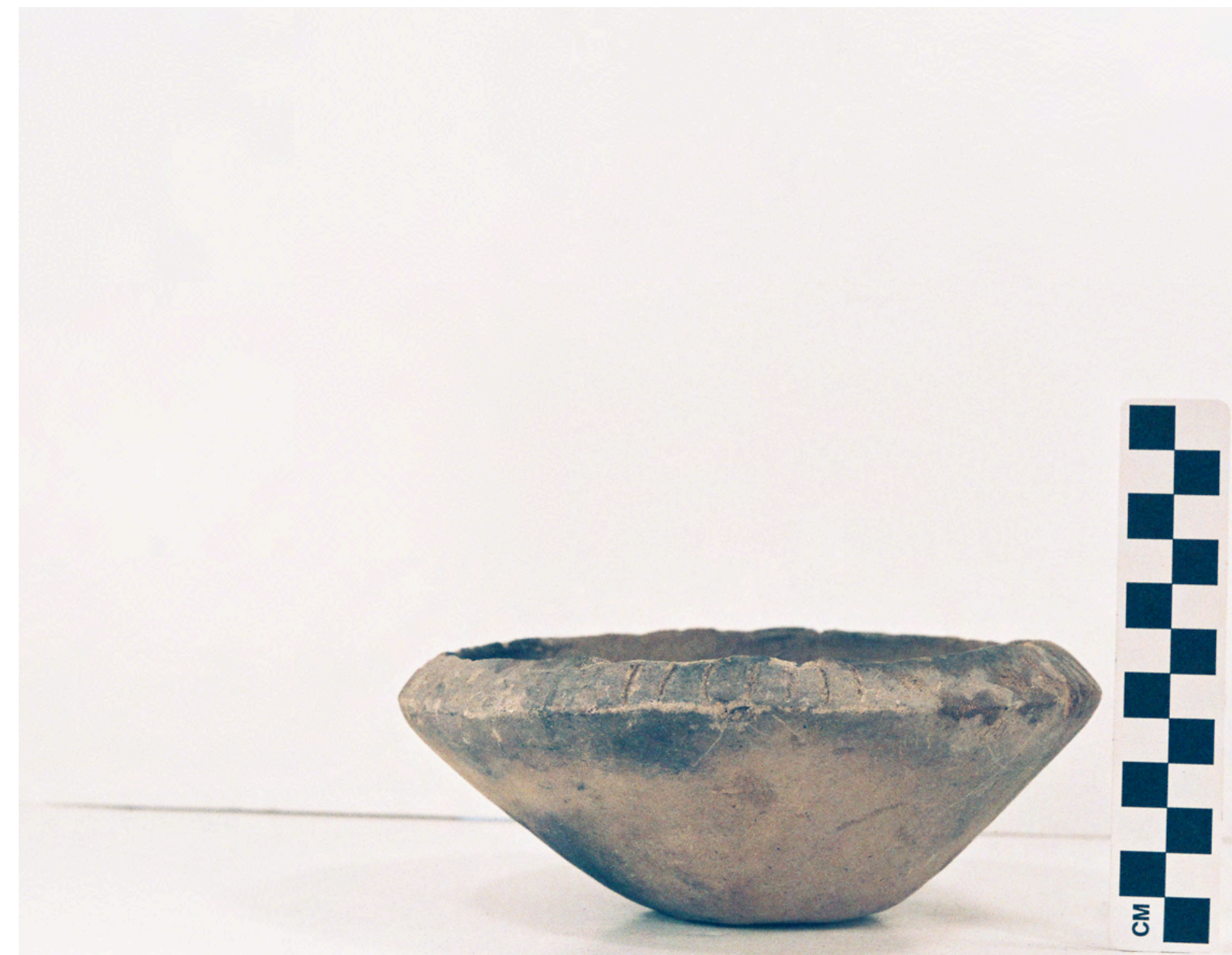

Figure 8d 


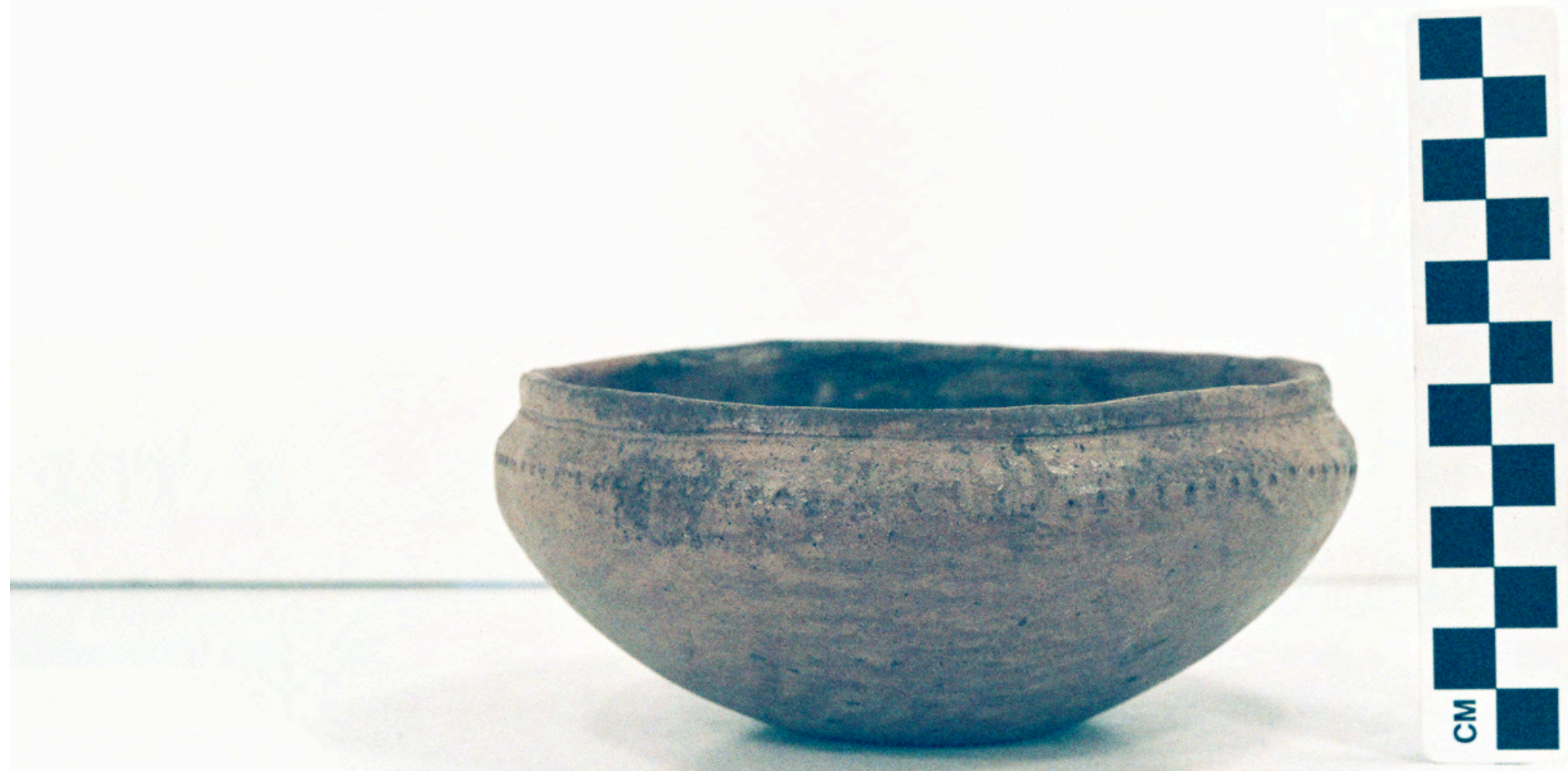

Figure 8e 


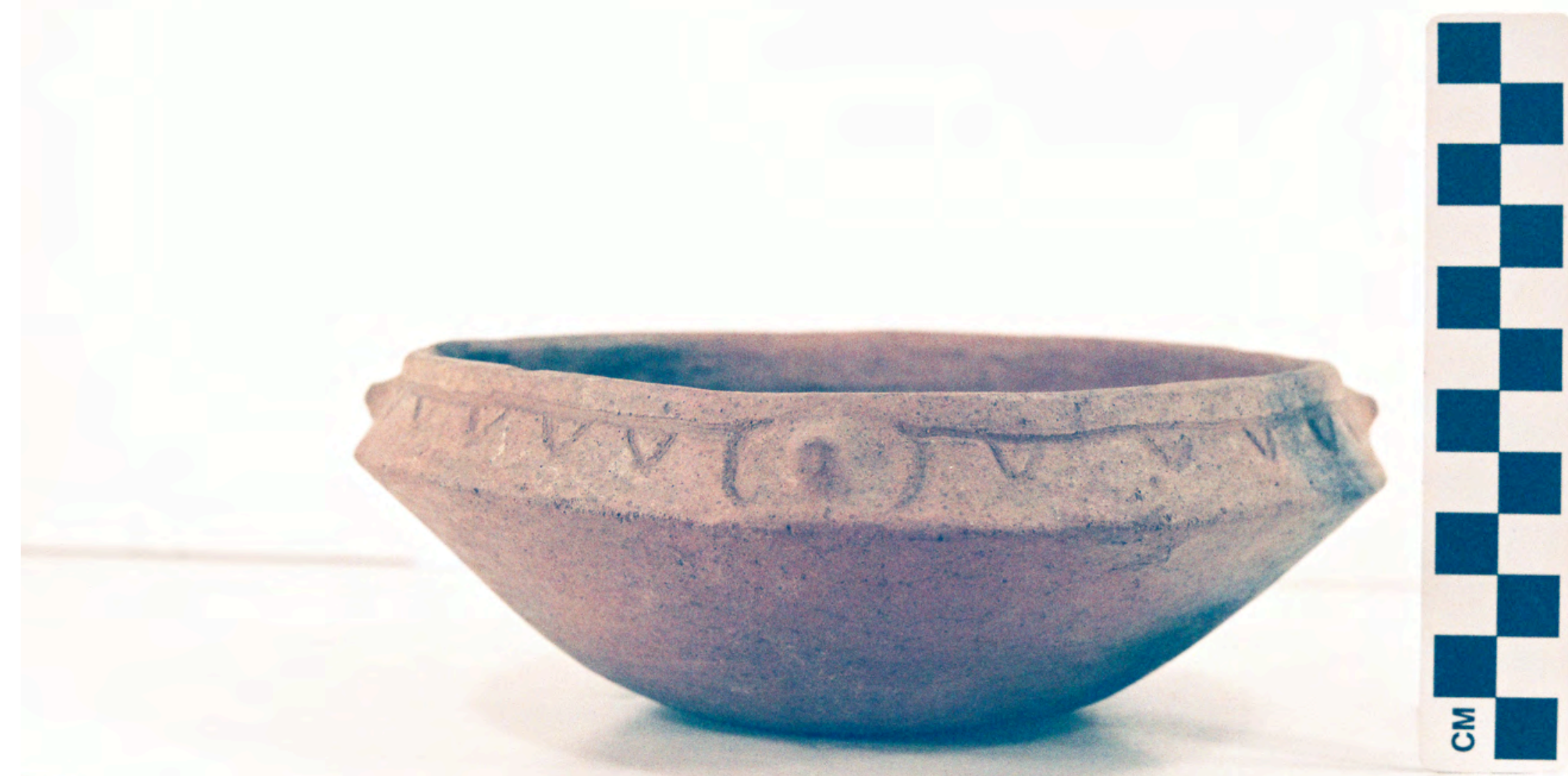

Figure $8 \mathrm{f}$ 


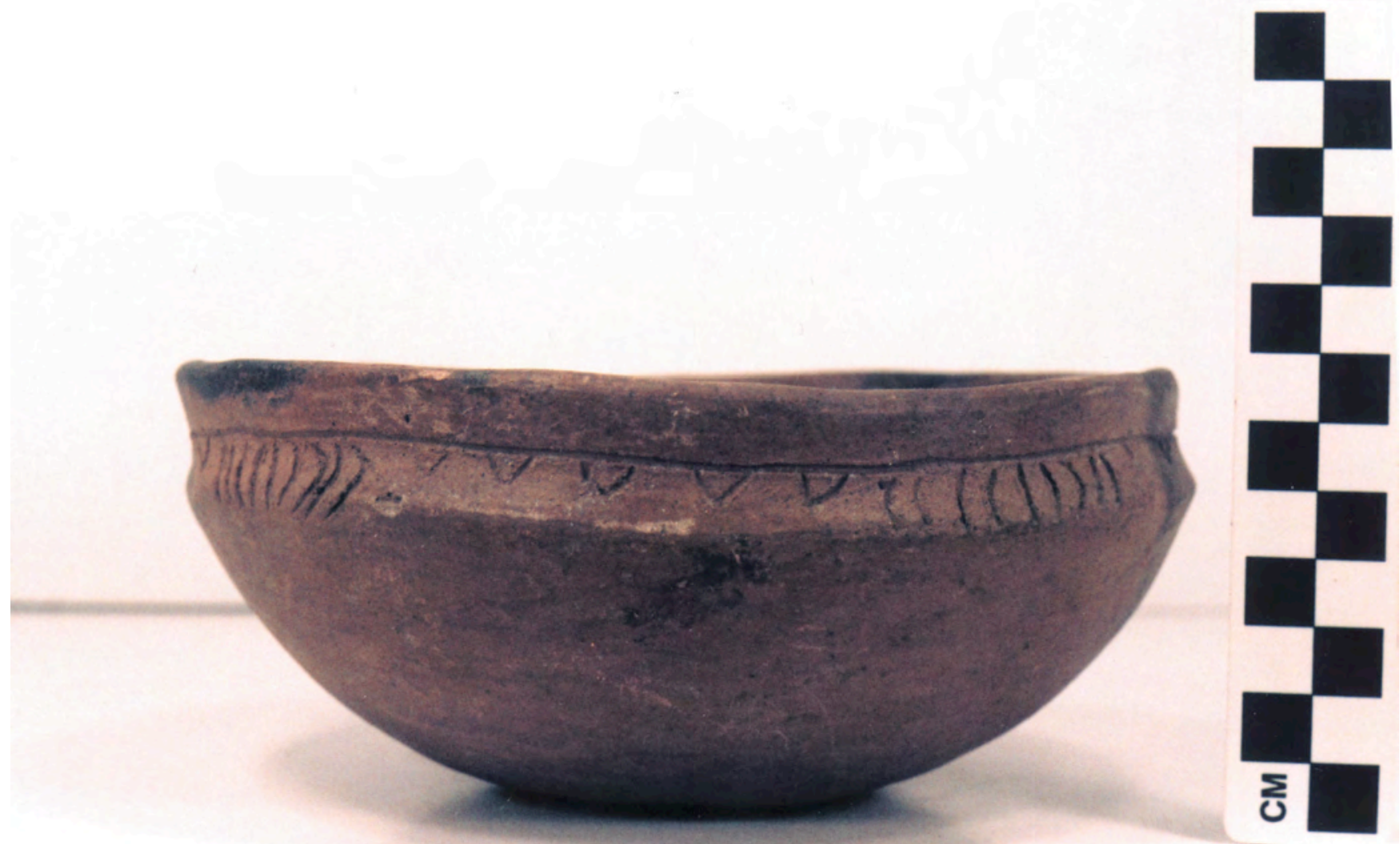

Figure 8g 


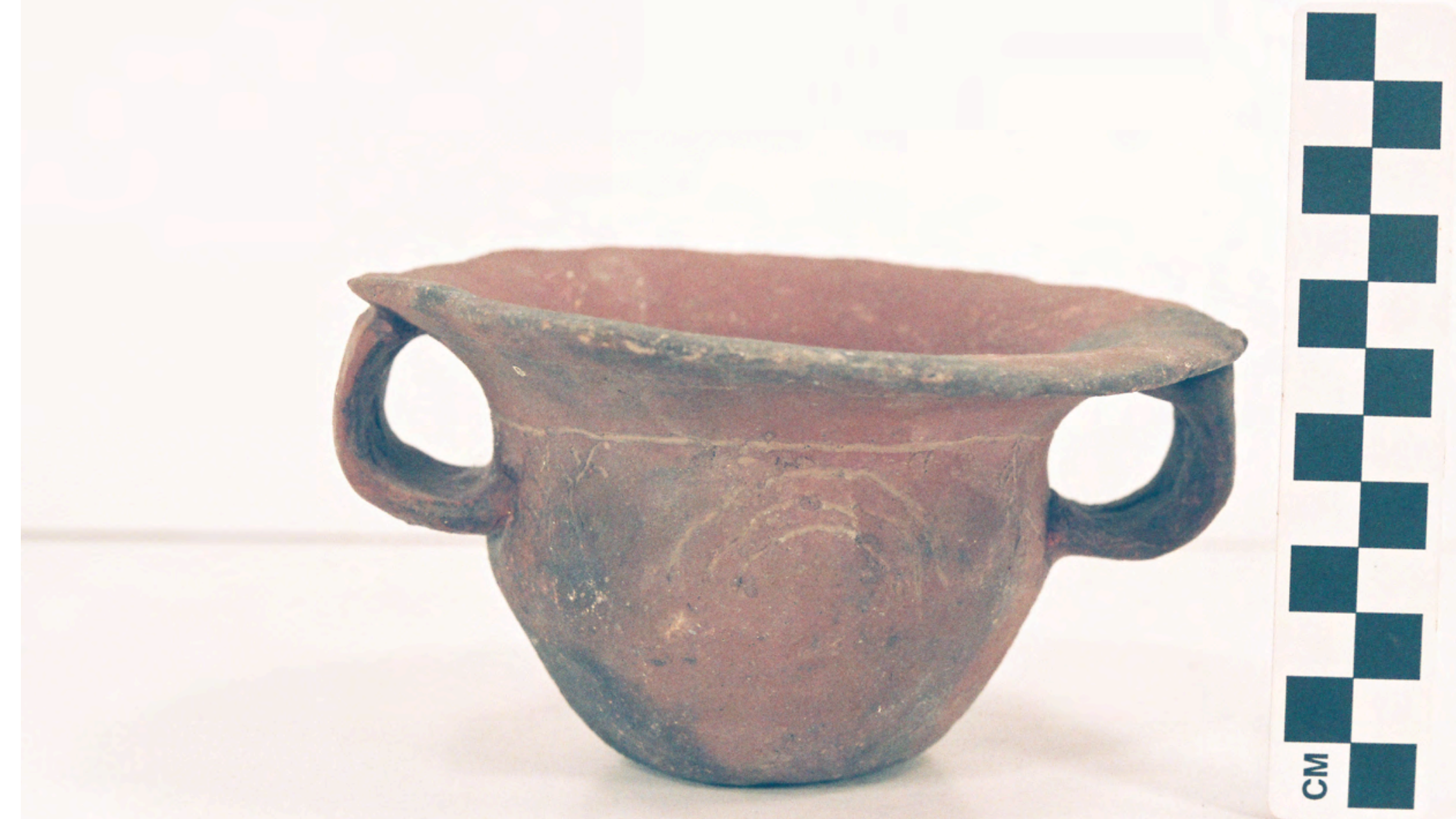

Figure $8 \mathrm{~h}$ 


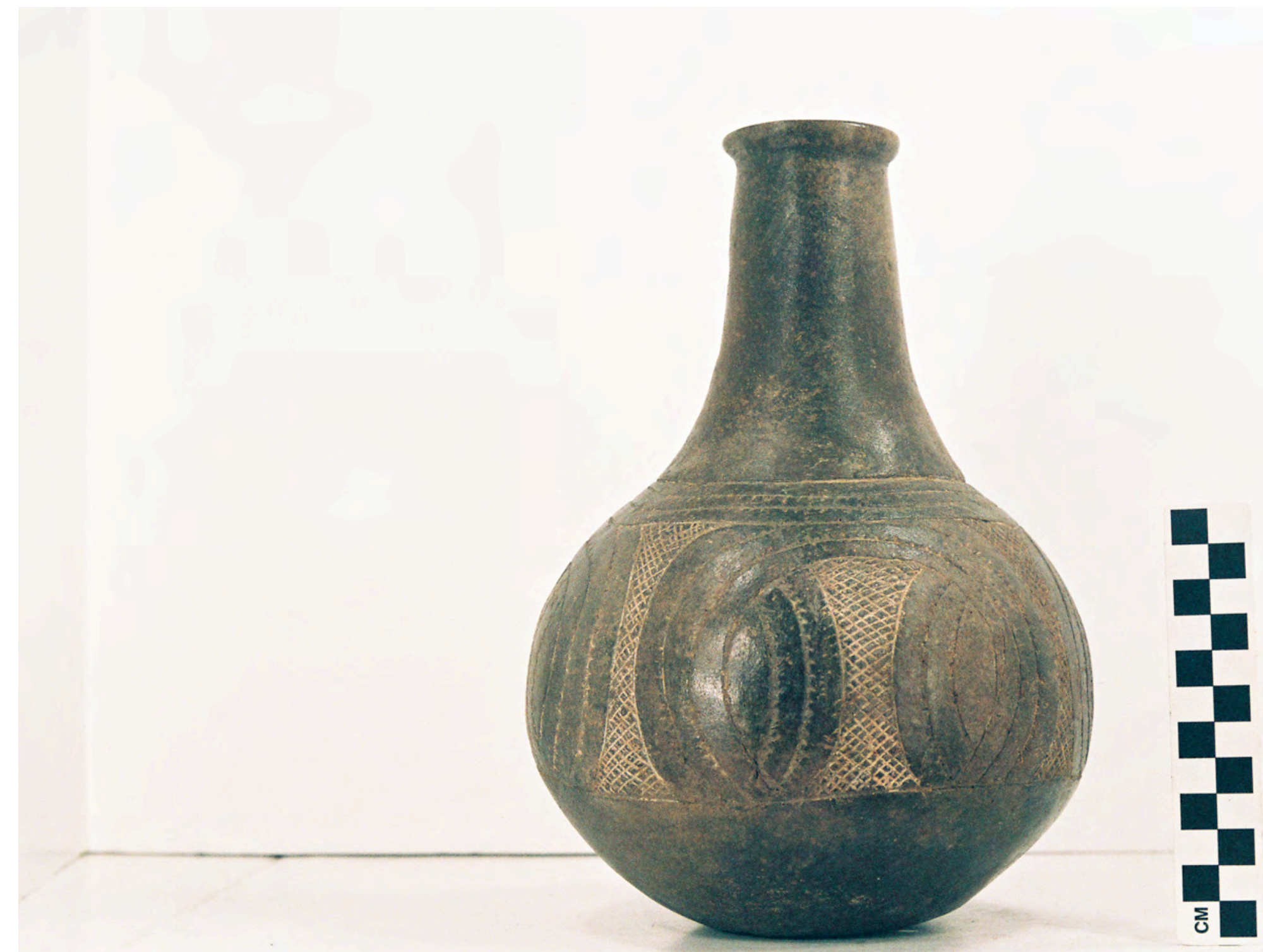

Figure 9a 


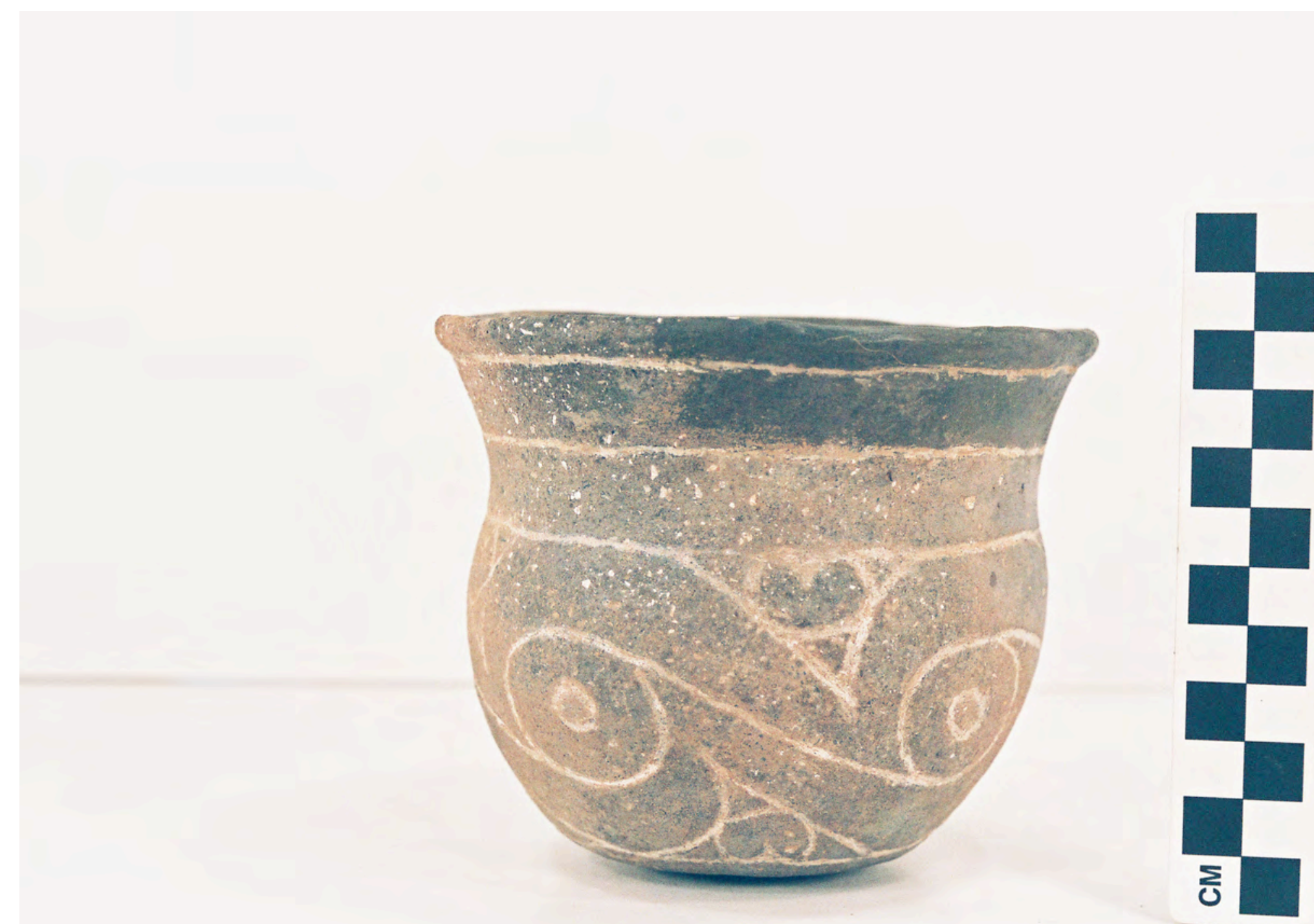

Figure $9 b$ 


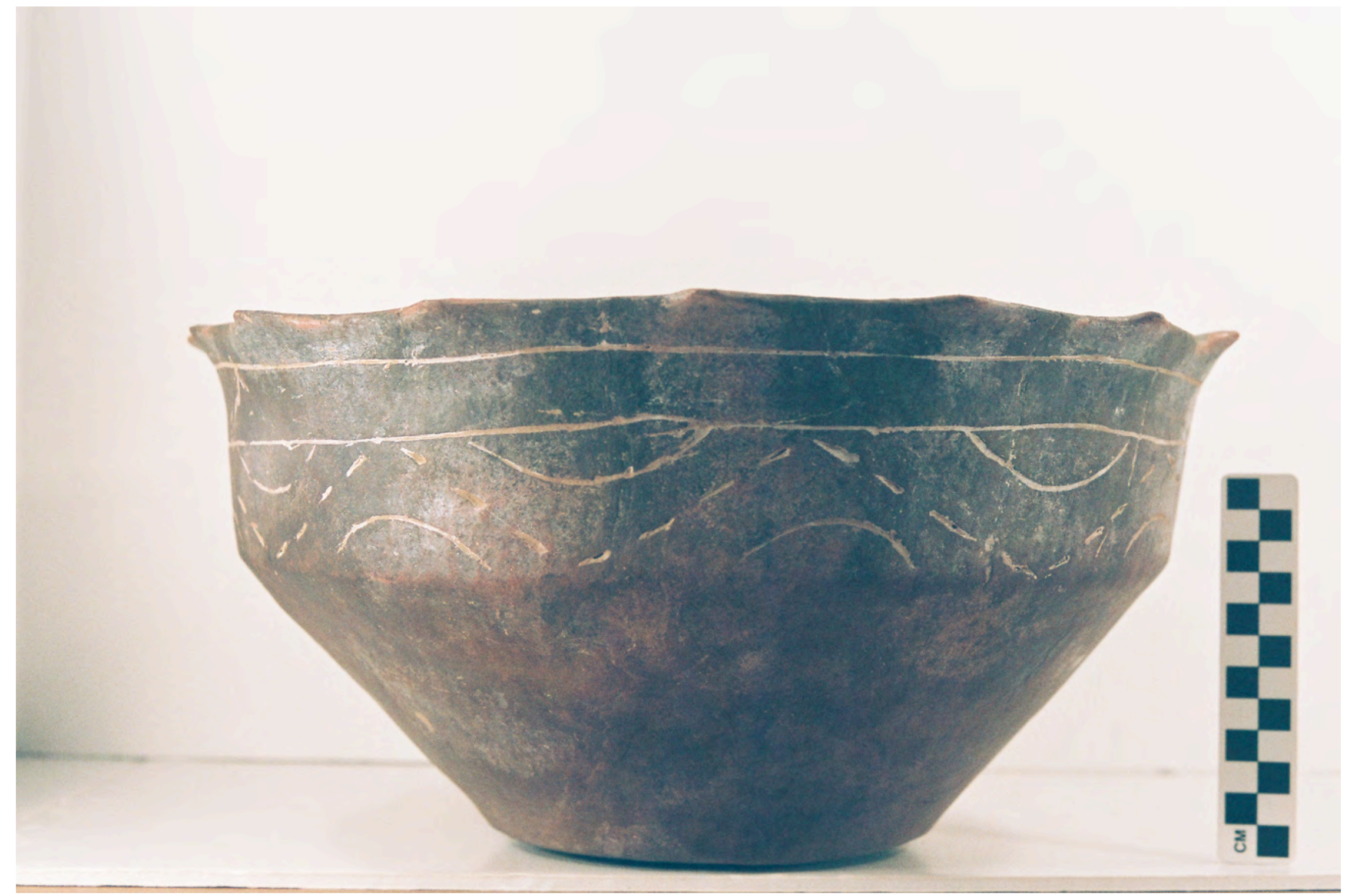

Figure 9c 


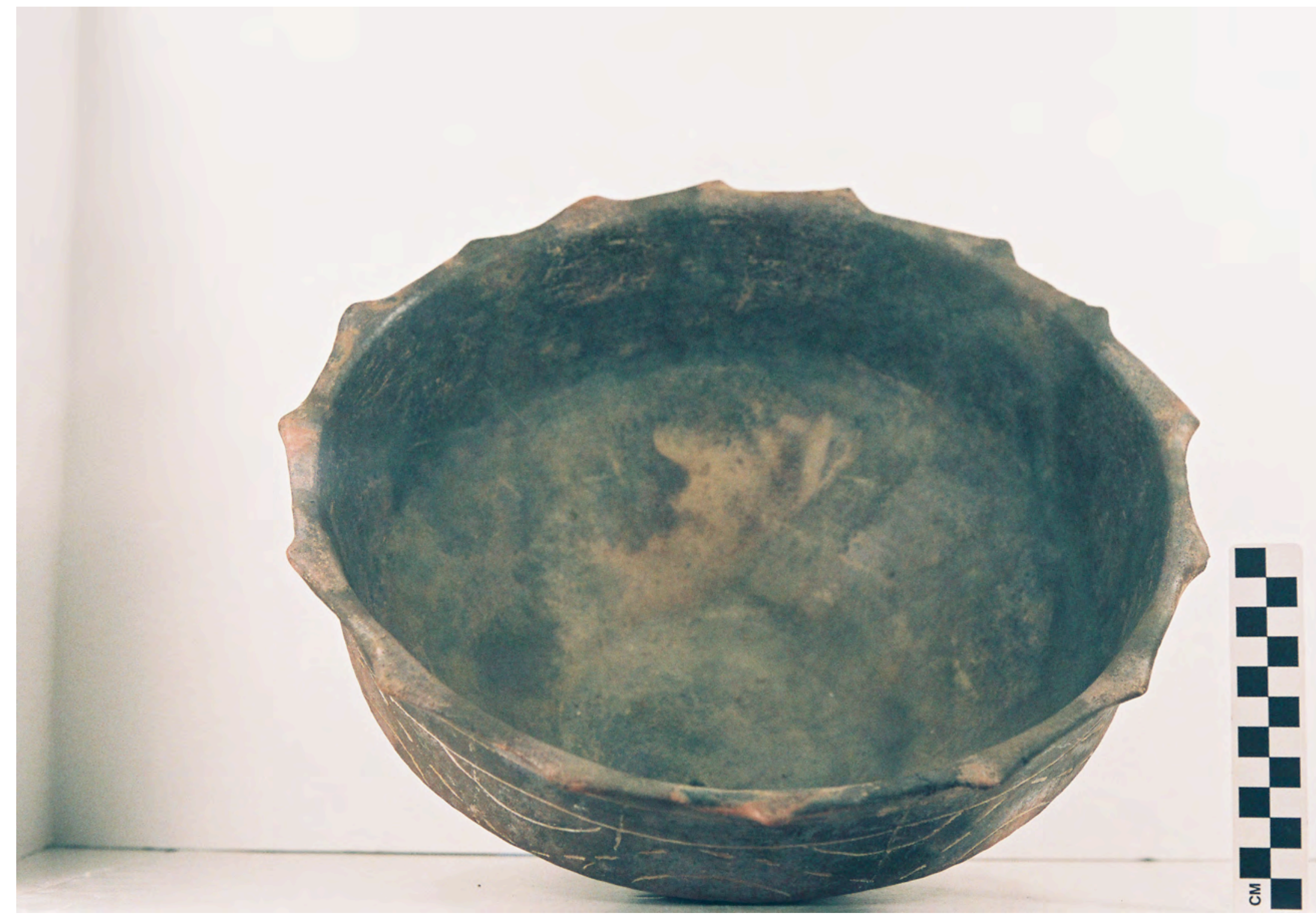

Figure 9d 


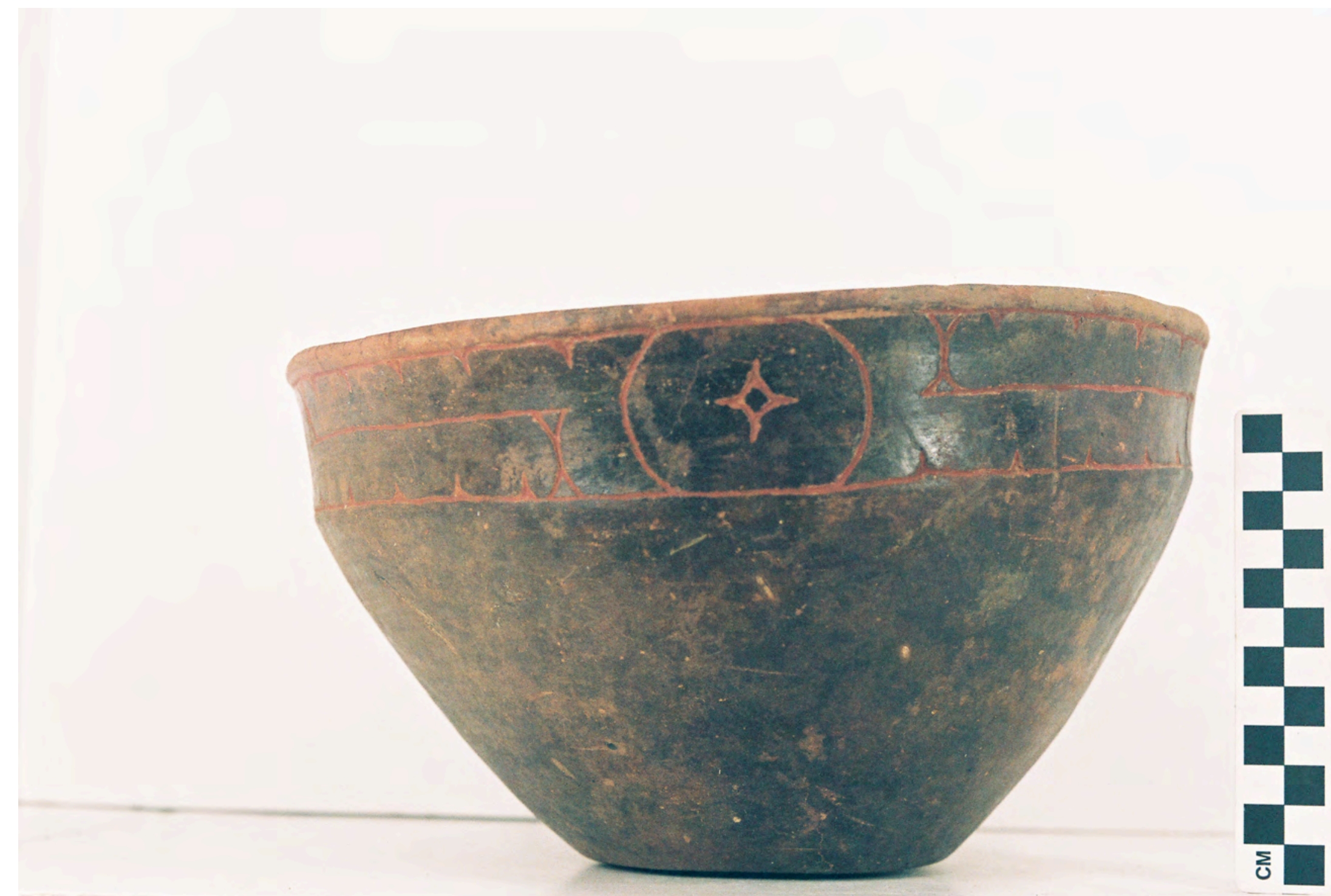

Figure 10a 

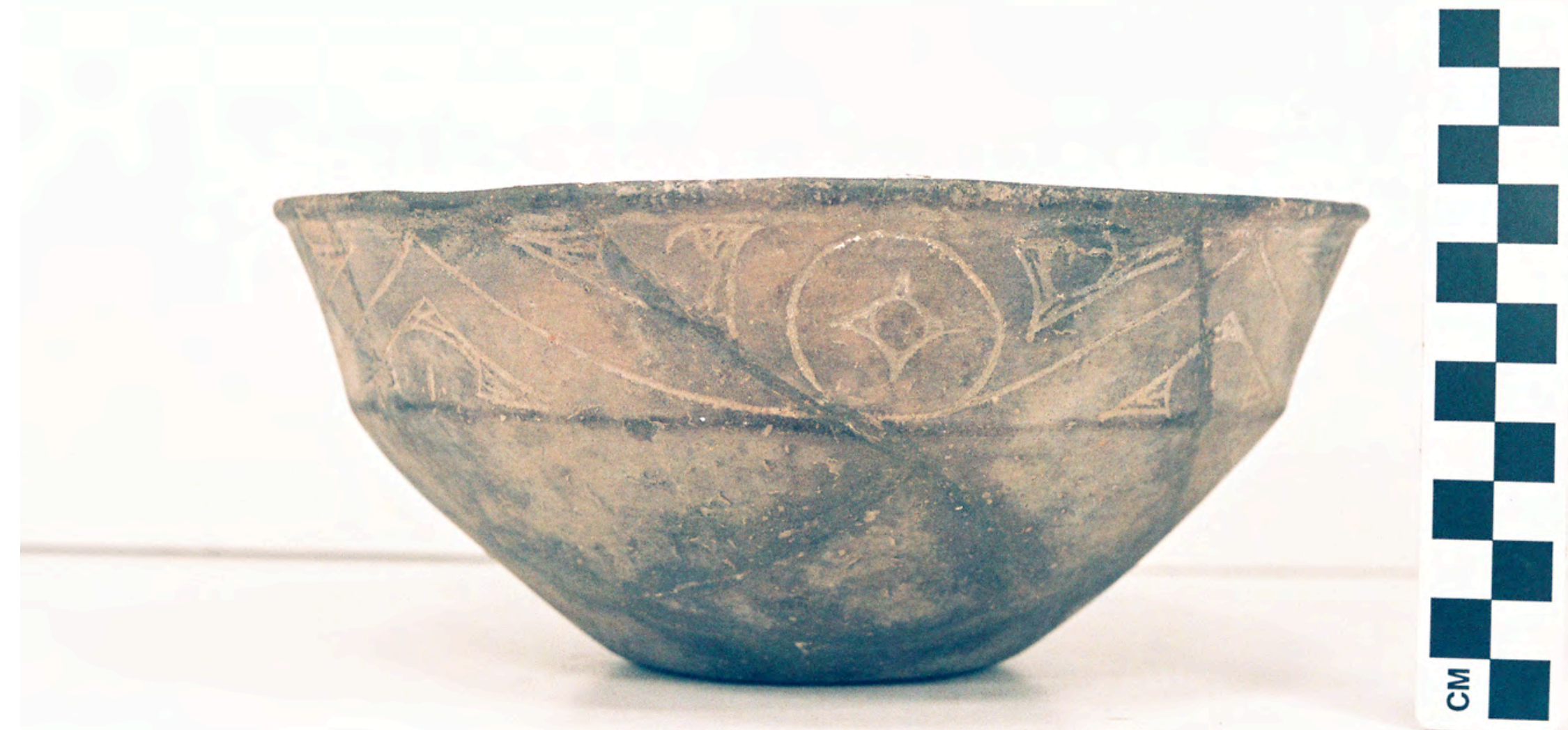

Figure $10 \mathrm{~b}$ 


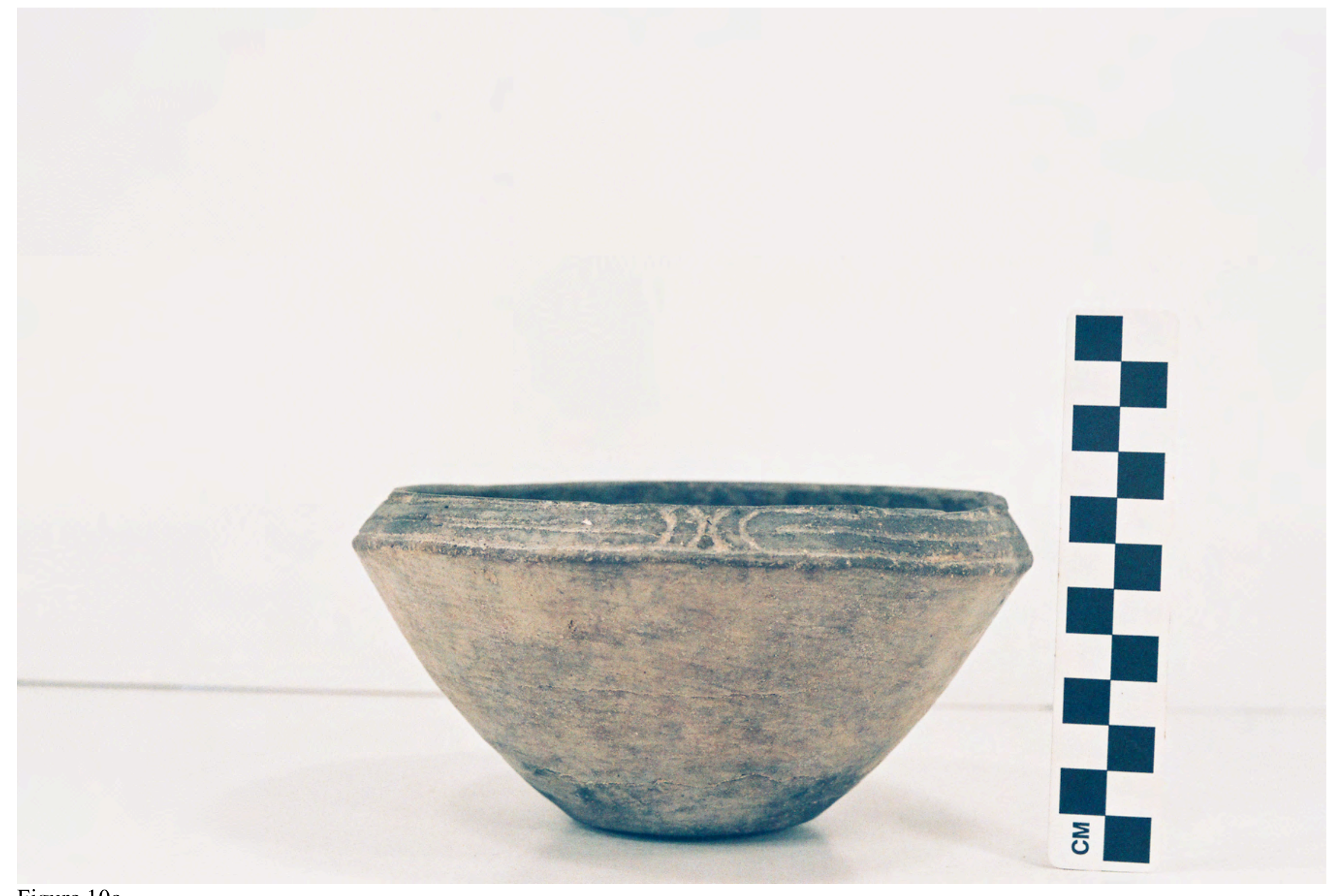

Figure 10c 


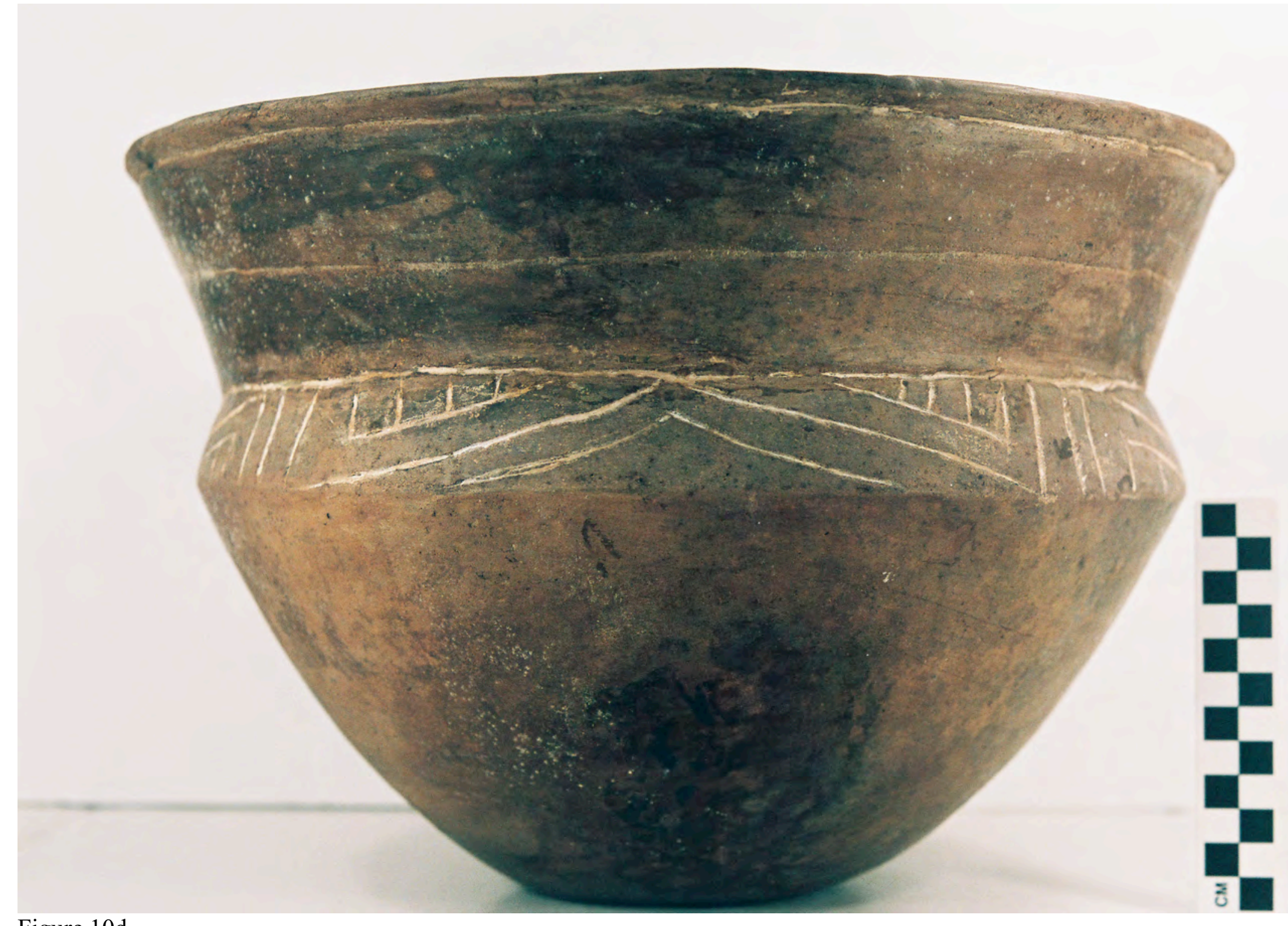

Figure 10d 


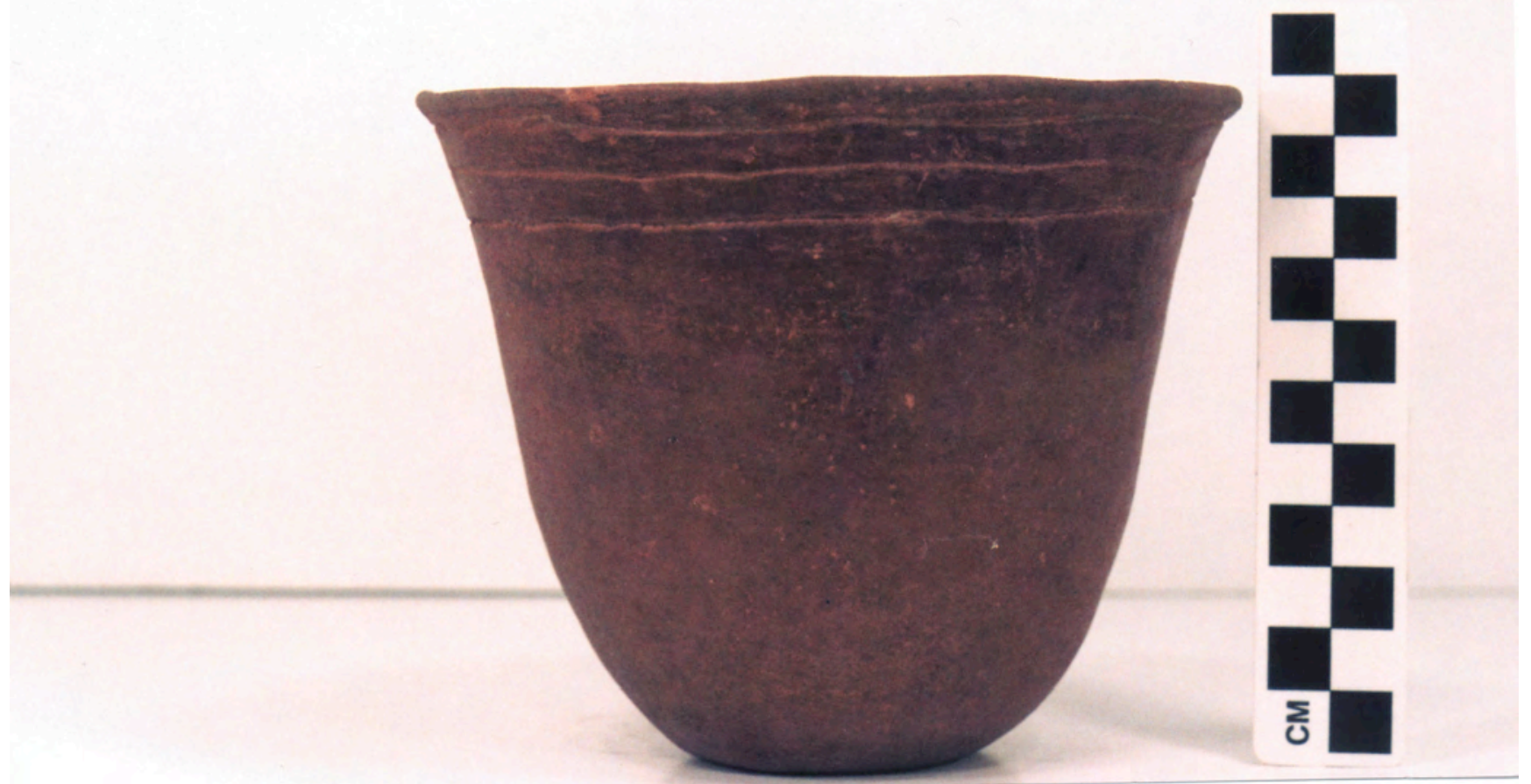

Figure 10e 


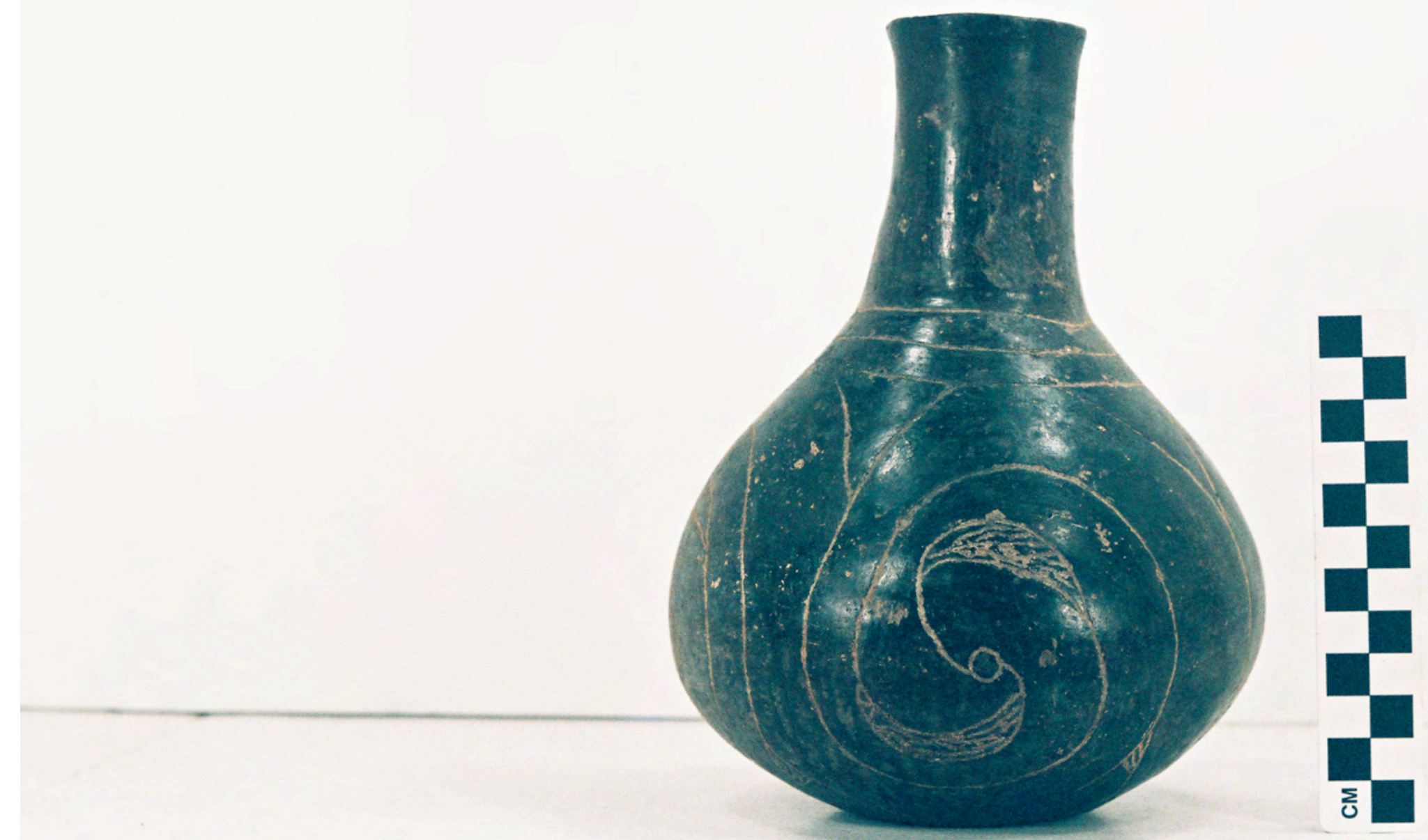

Figure 11a 


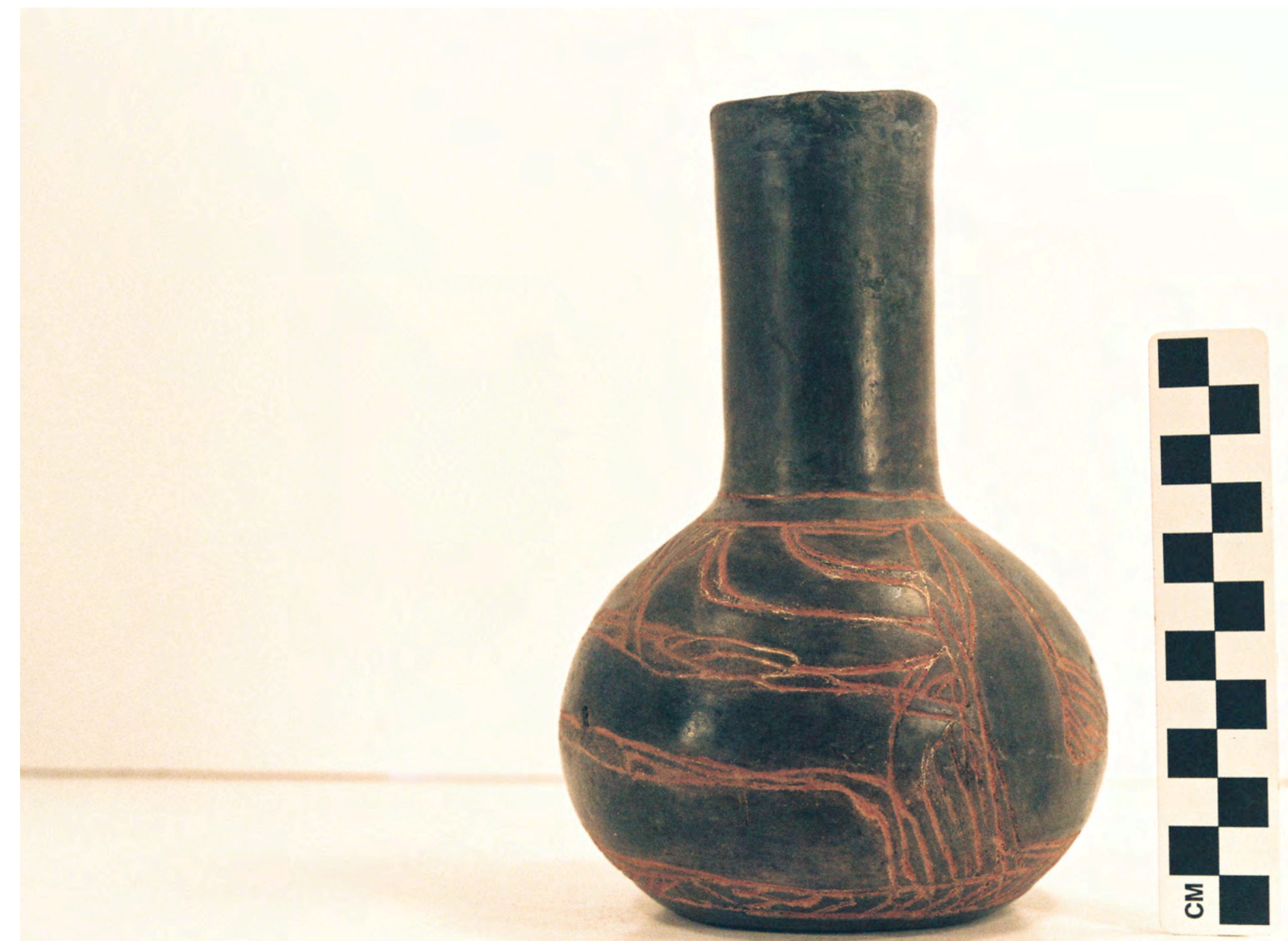

Figure 11b 

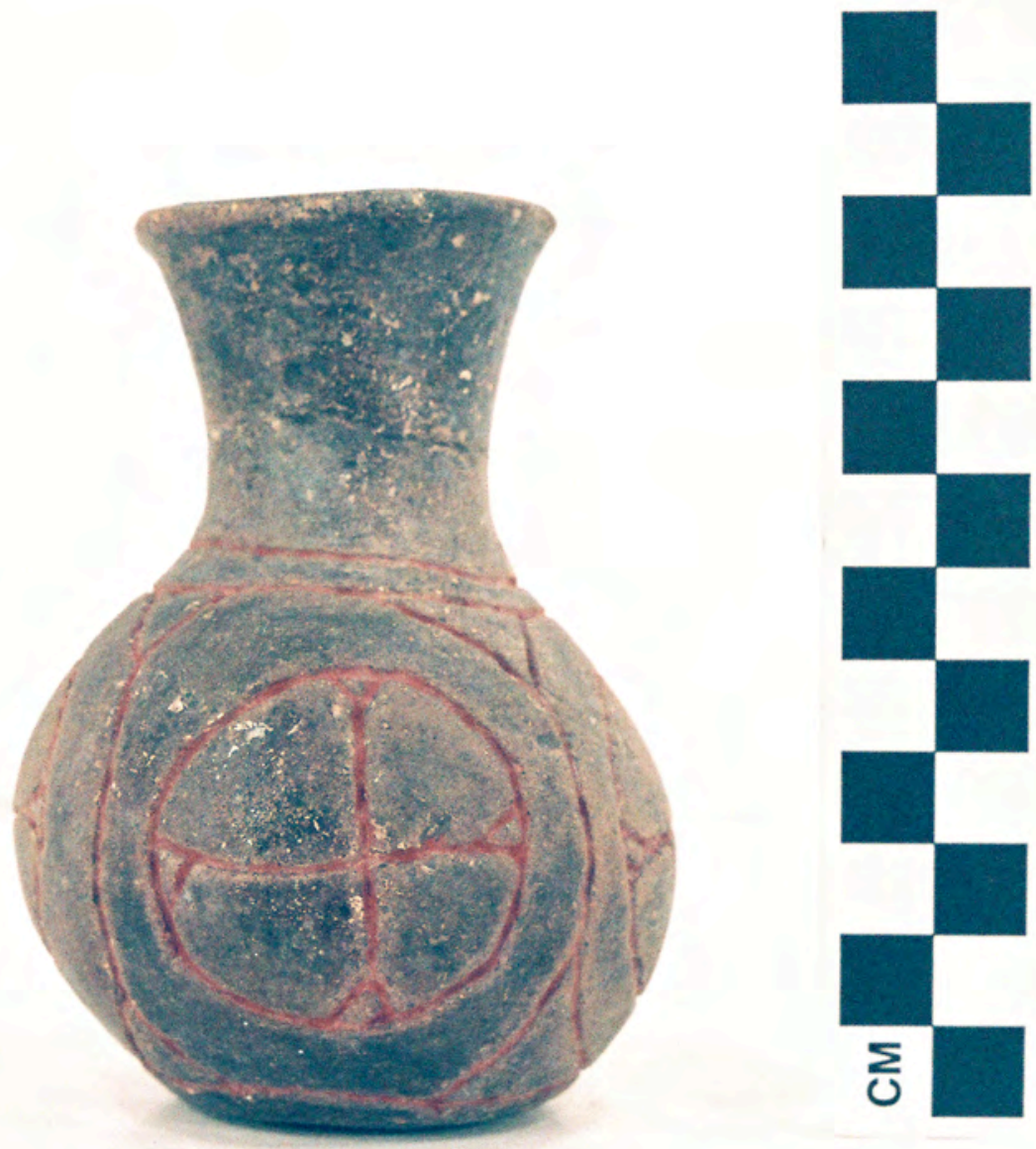

Figure 11c 


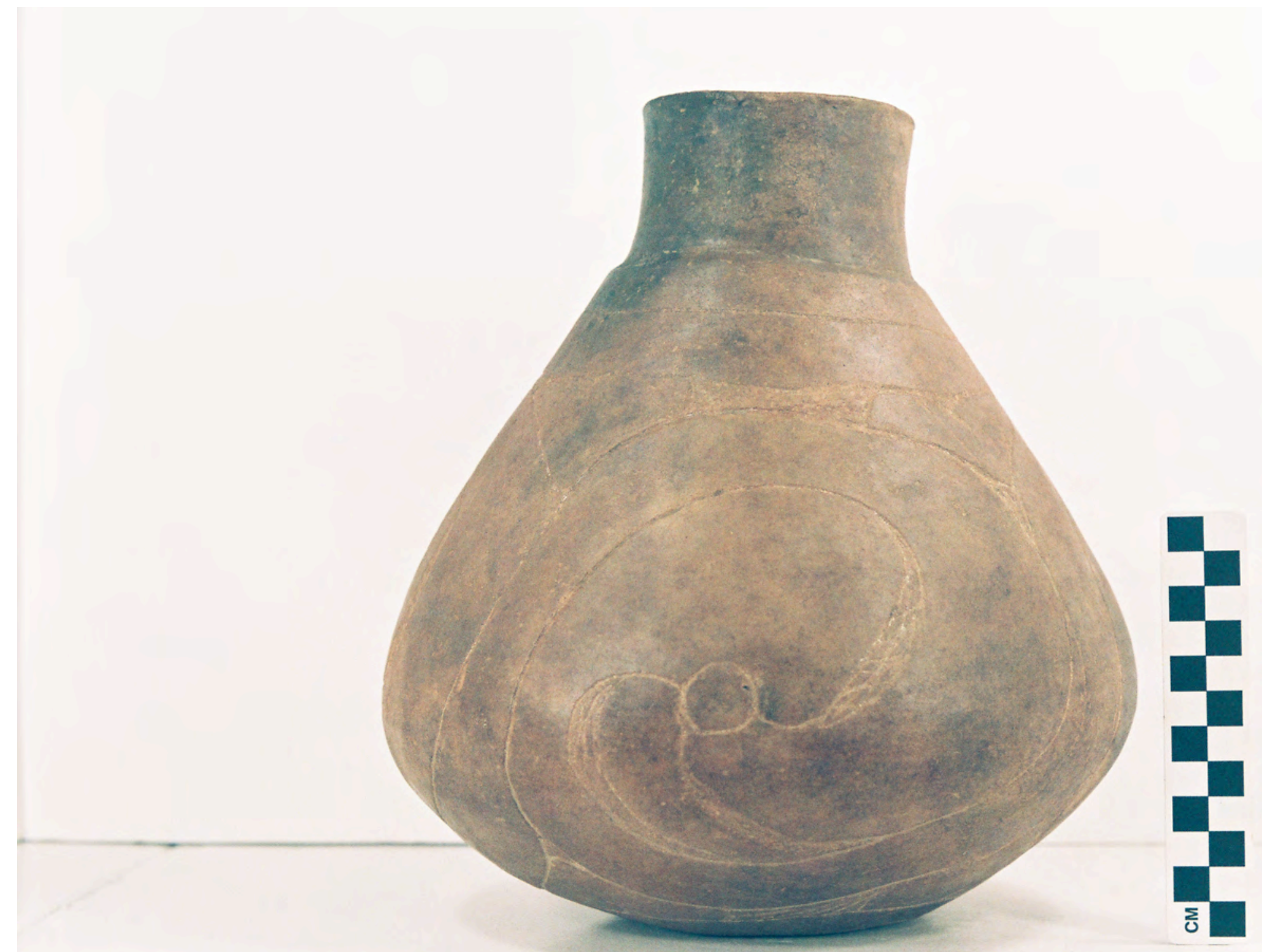

Figure 11d 


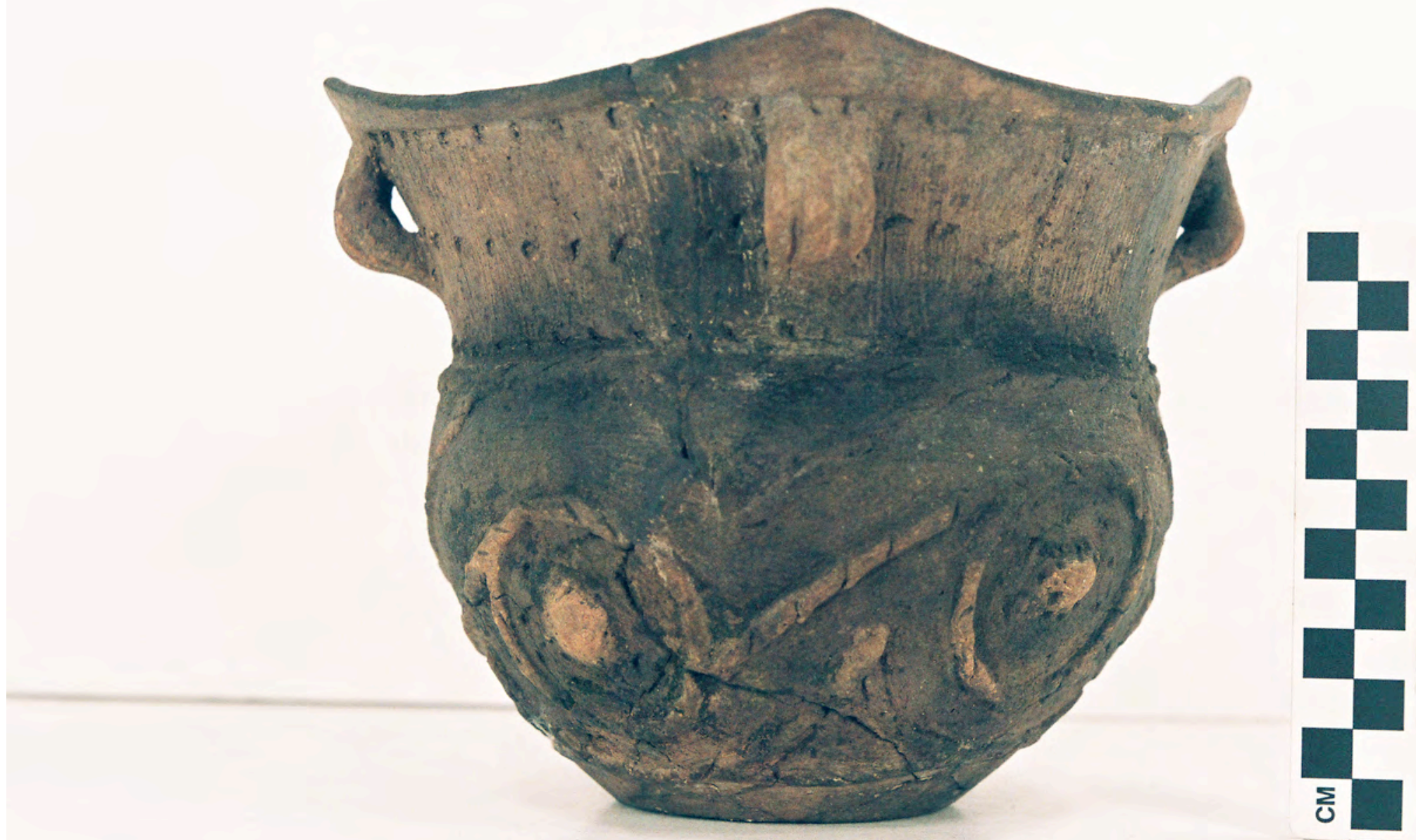

Figure 12a 


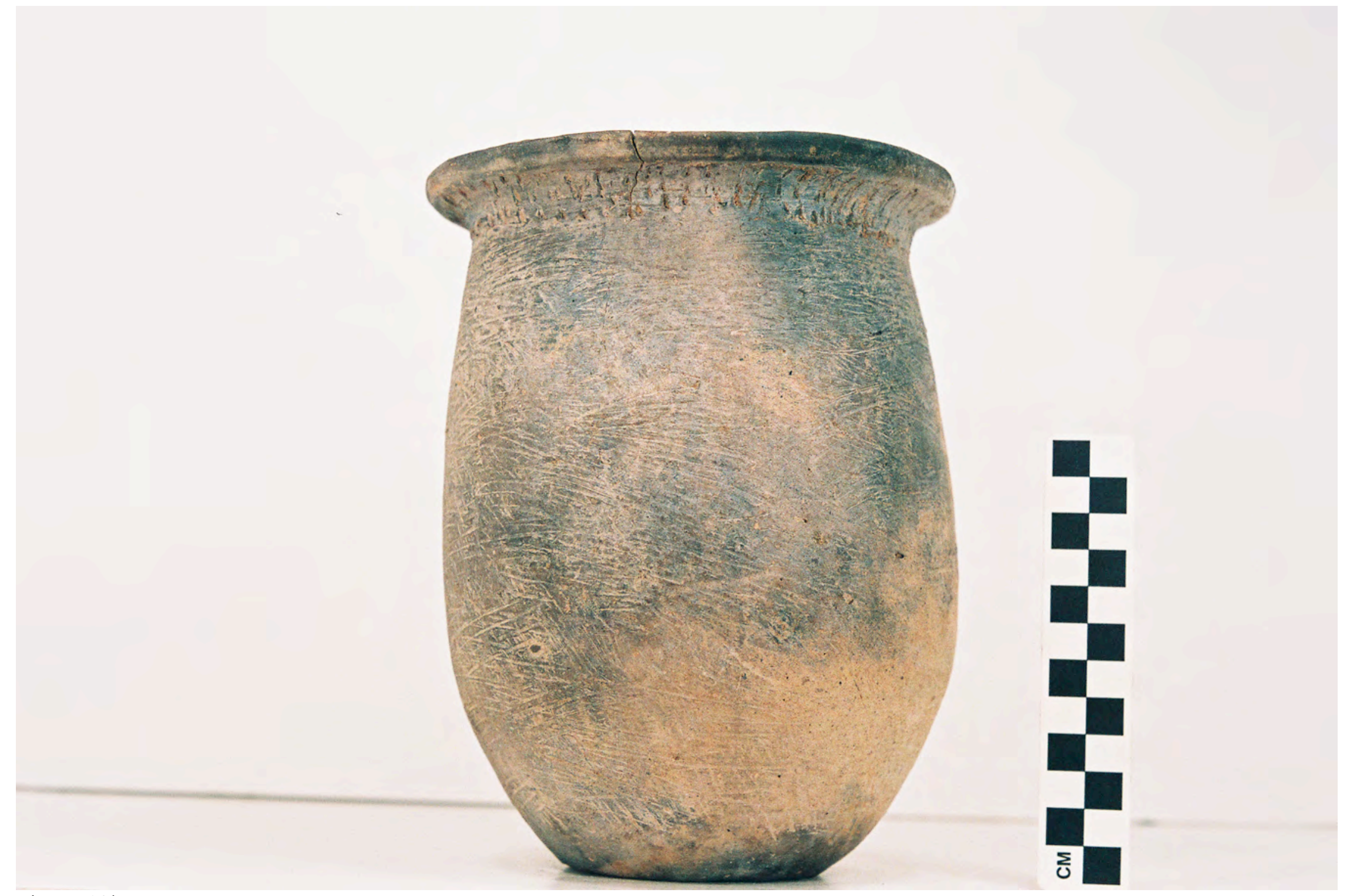

Figure $12 b$ 


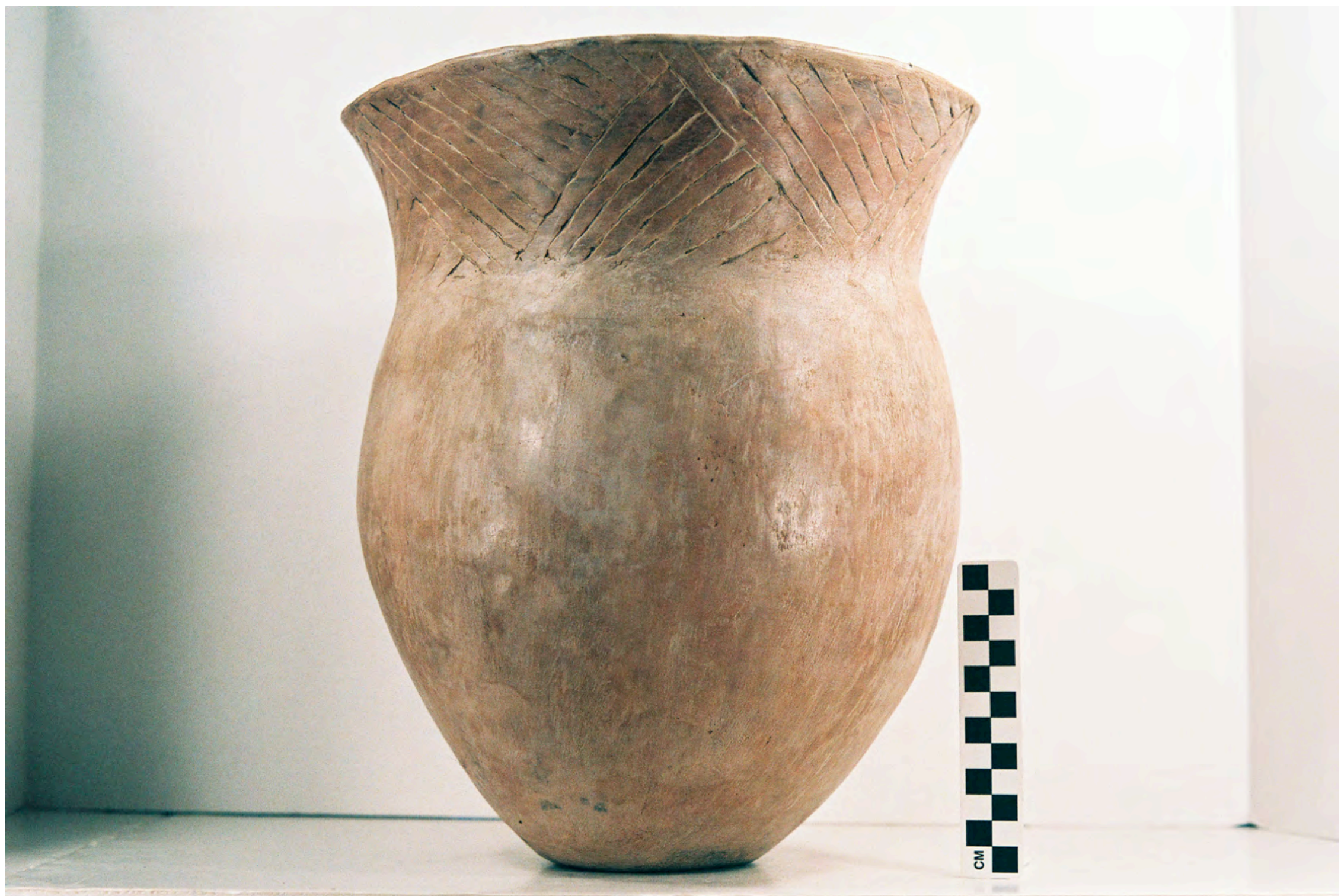

Figure 12c 


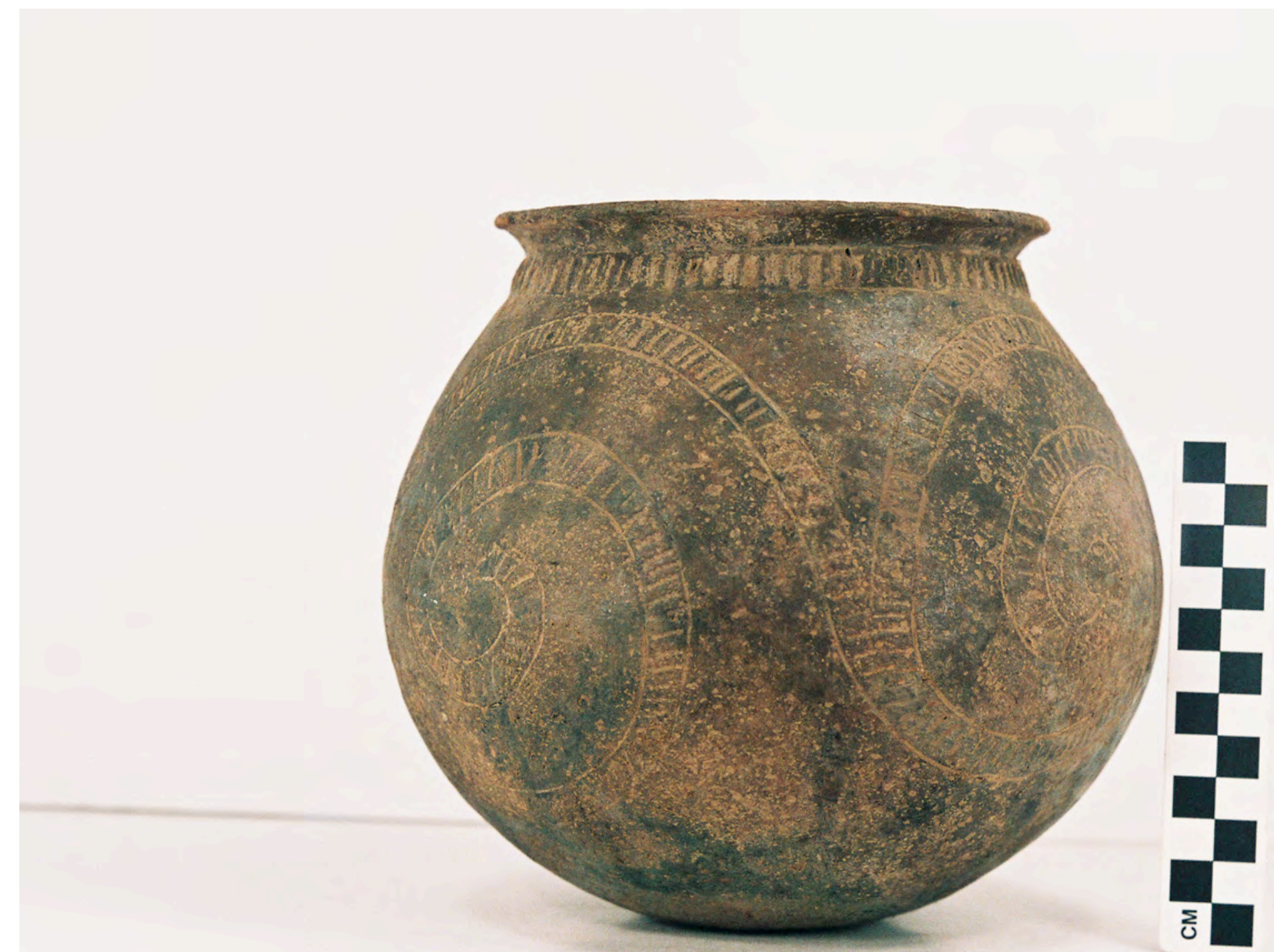

Figure 12d (and cover) 


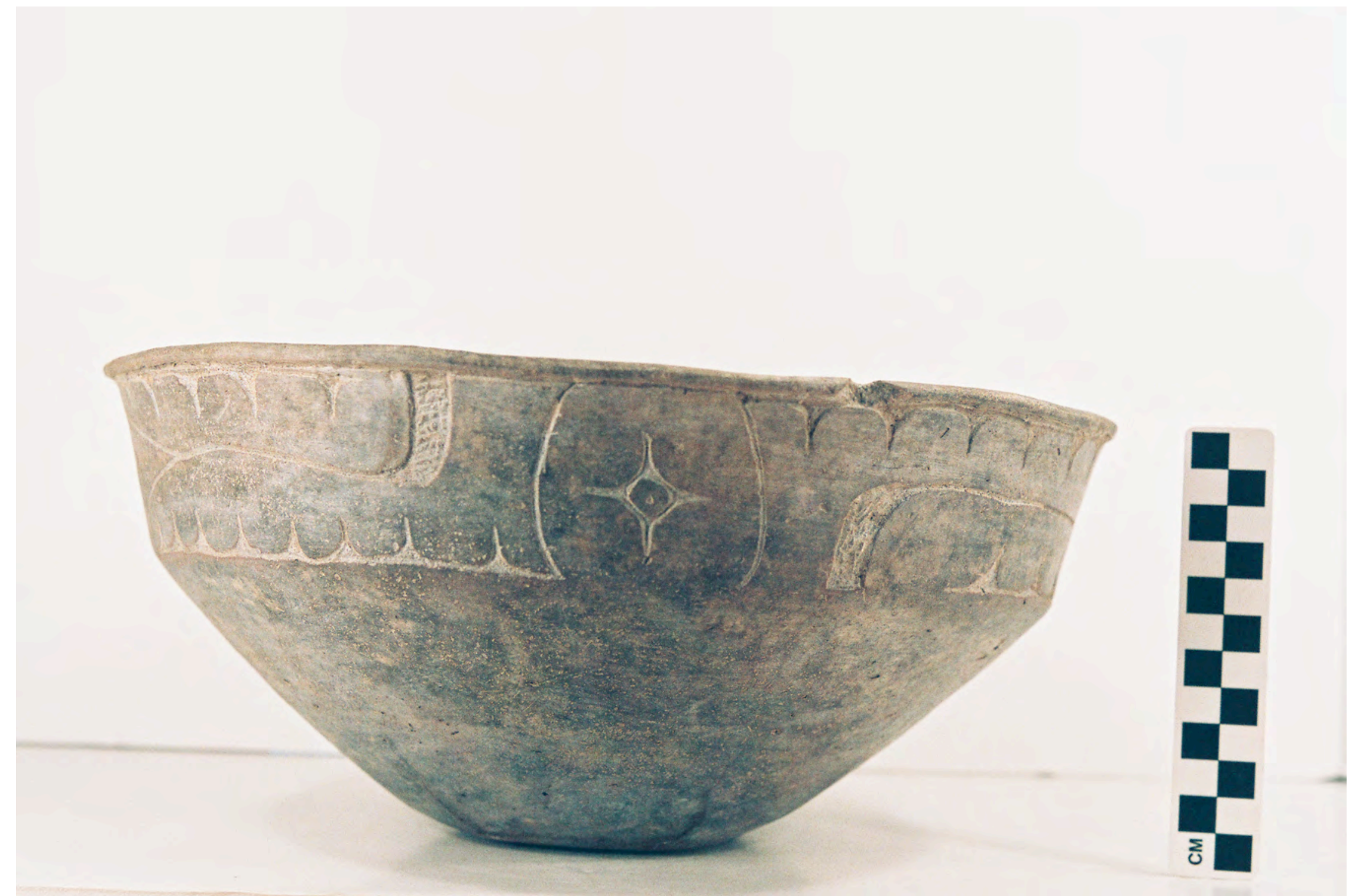

Figure 13a 


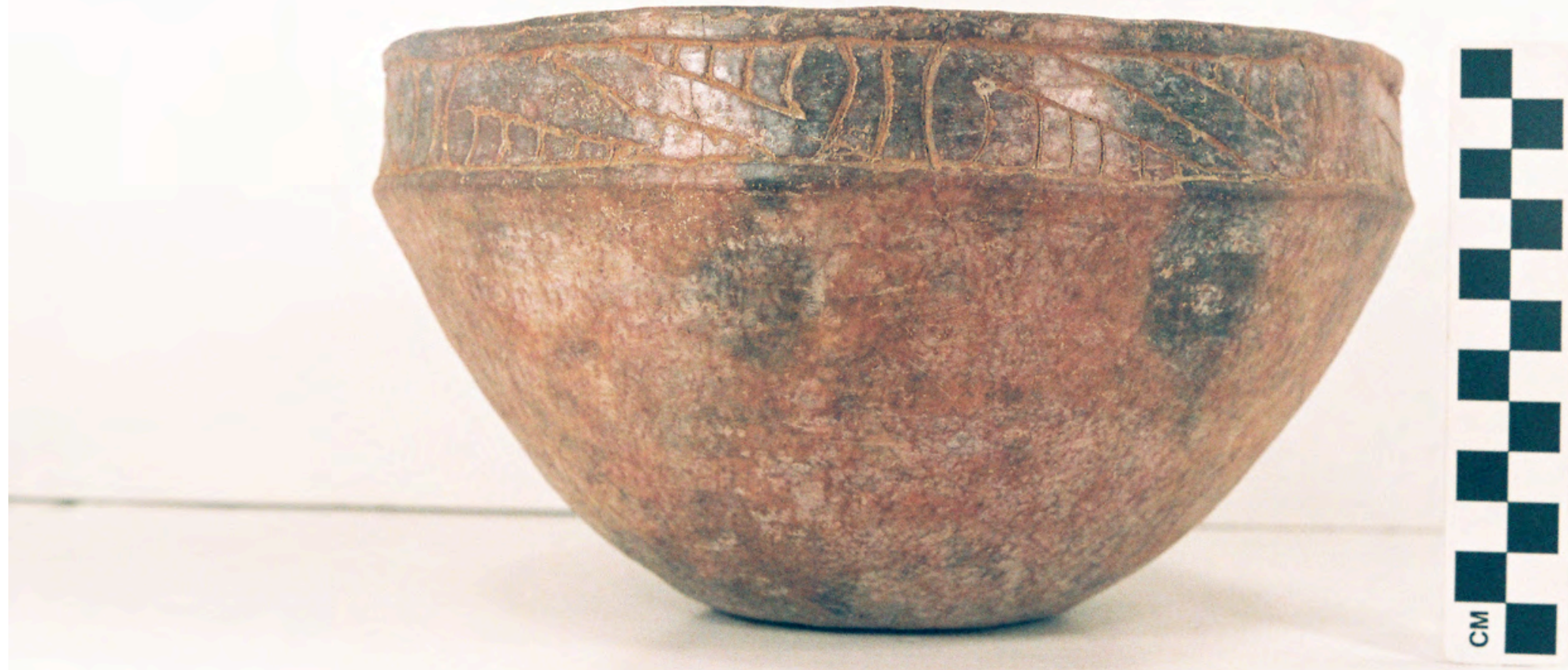

Figure $13 b$ 


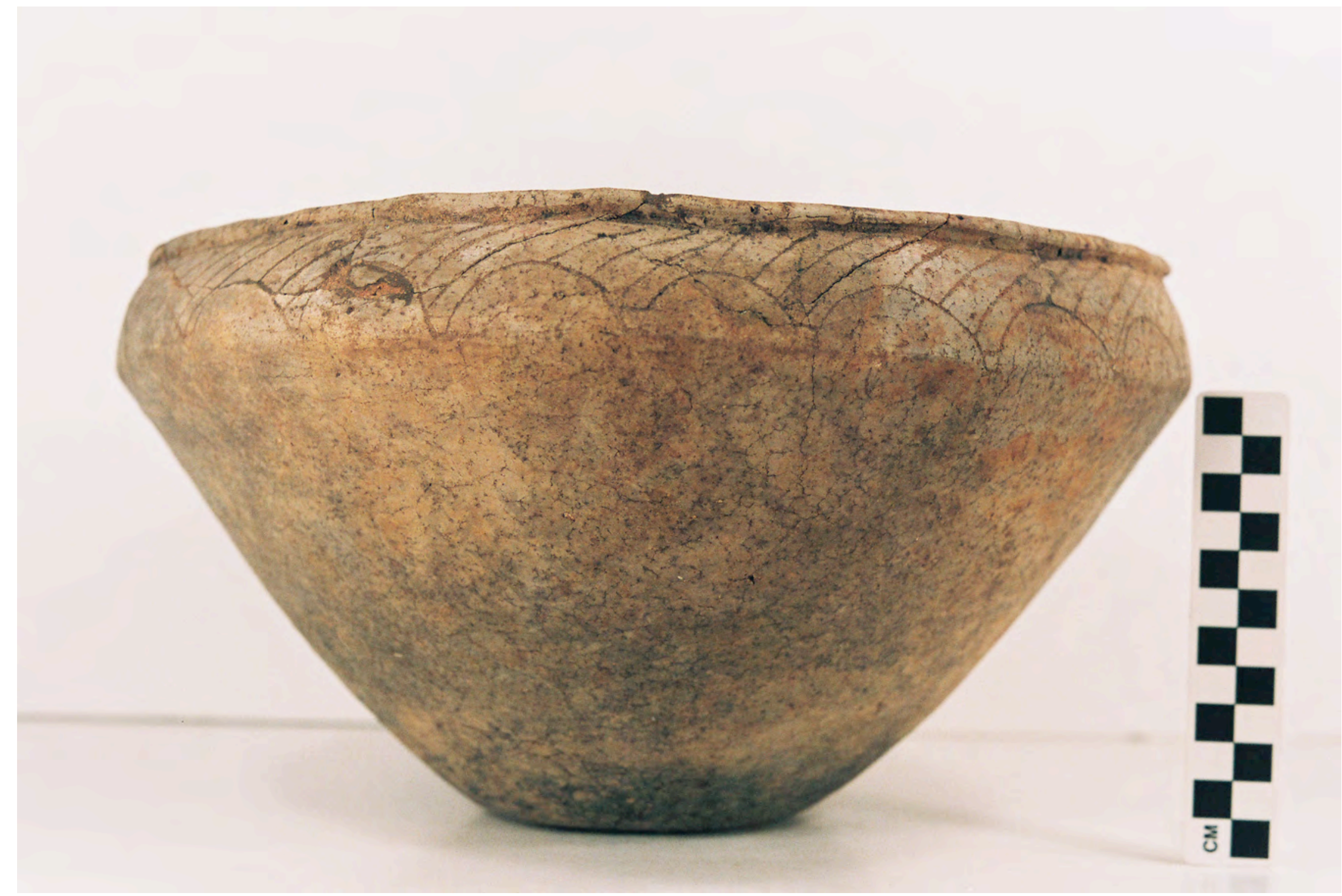

Figure 13c 


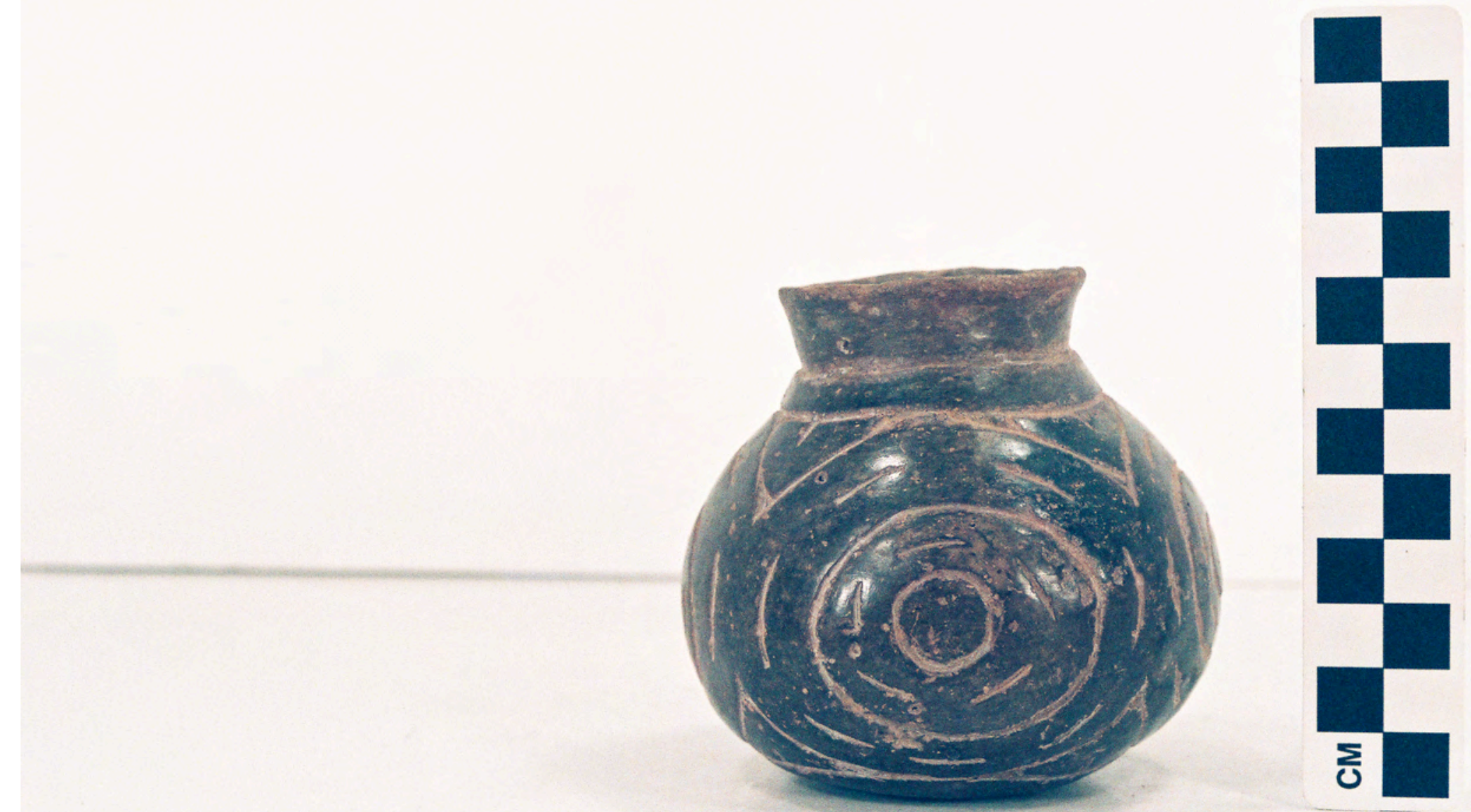

Figure 14a 


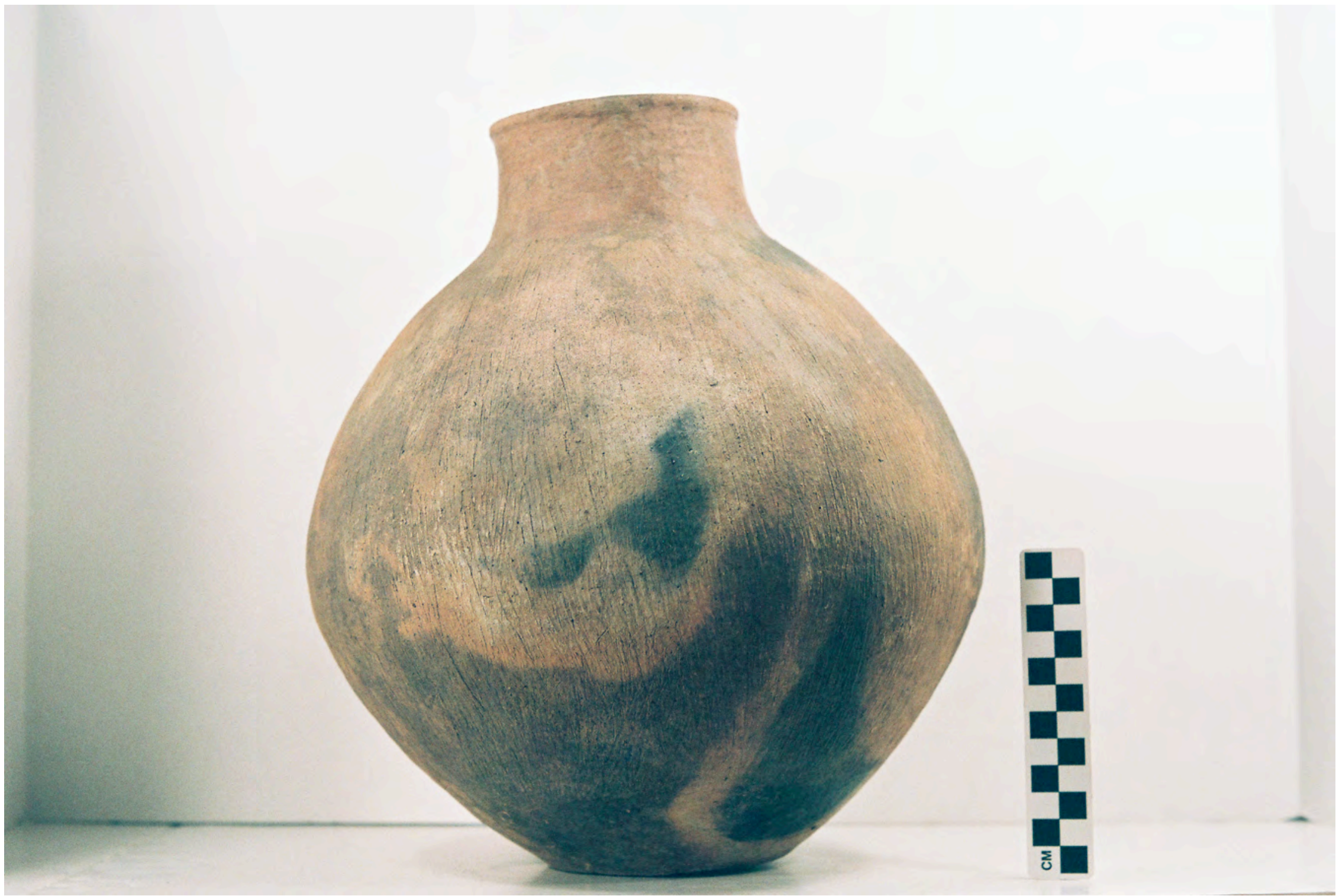

Figure $14 b$ 


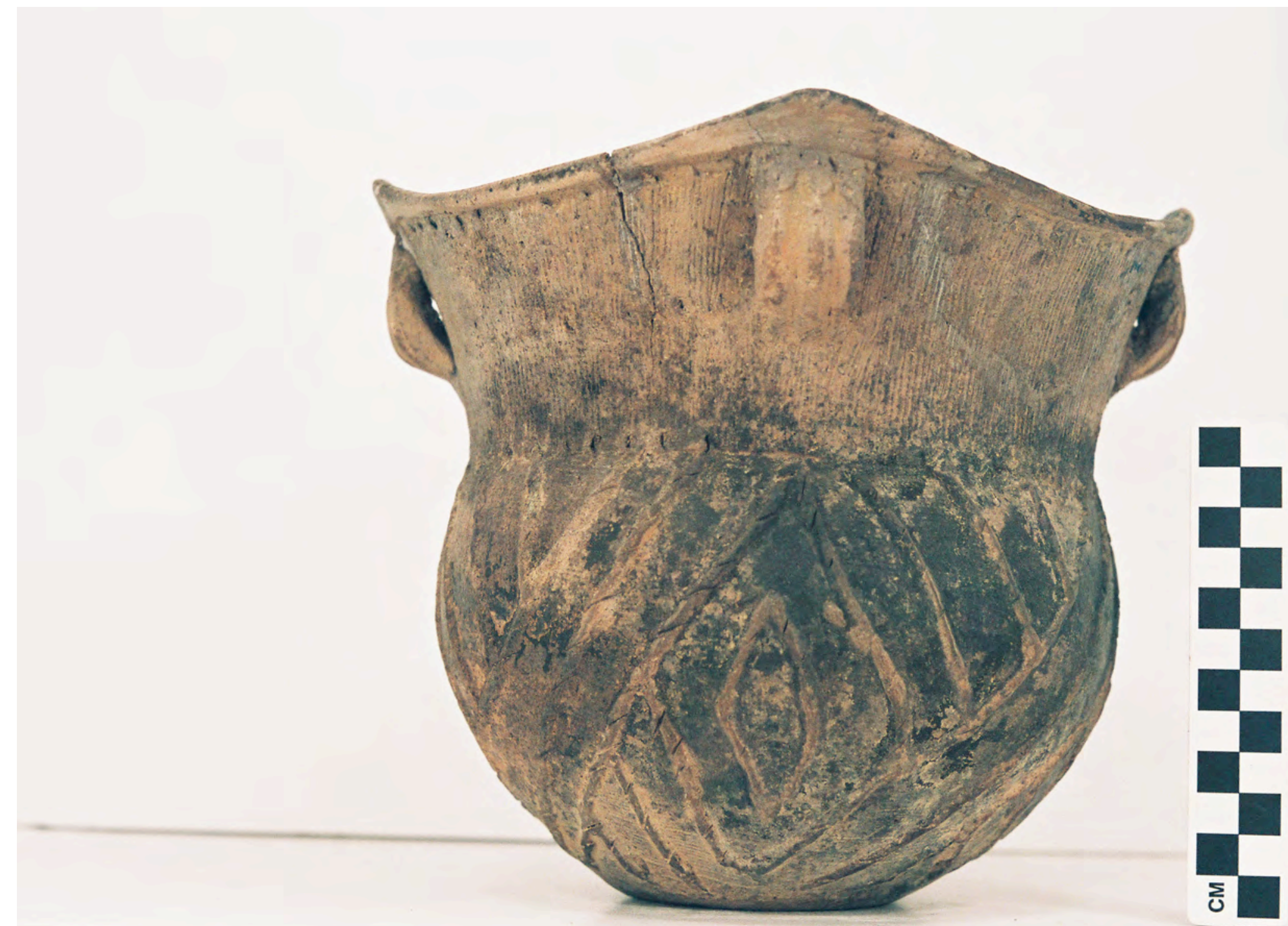

Figure 15 


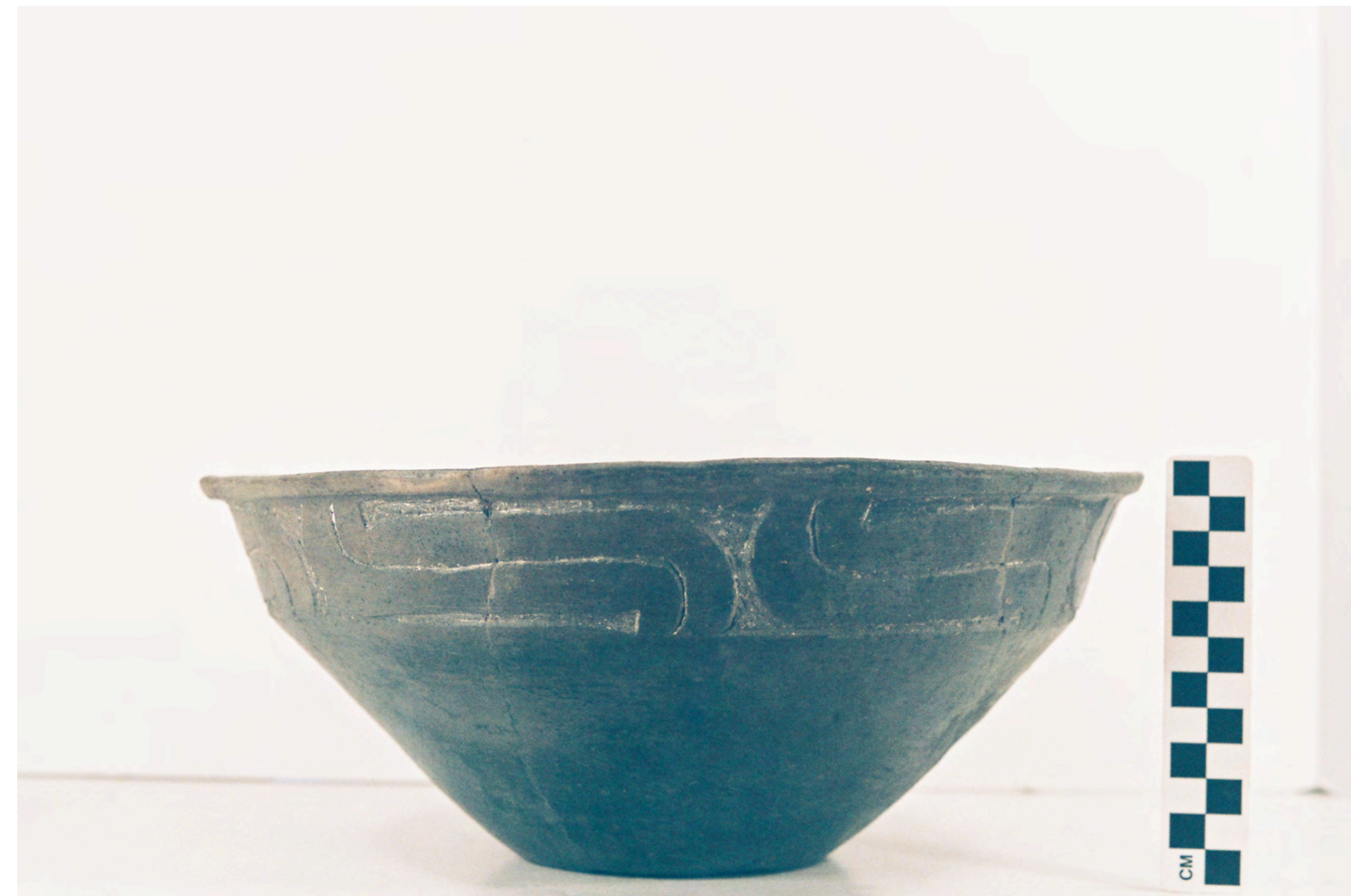

Figure 16a 


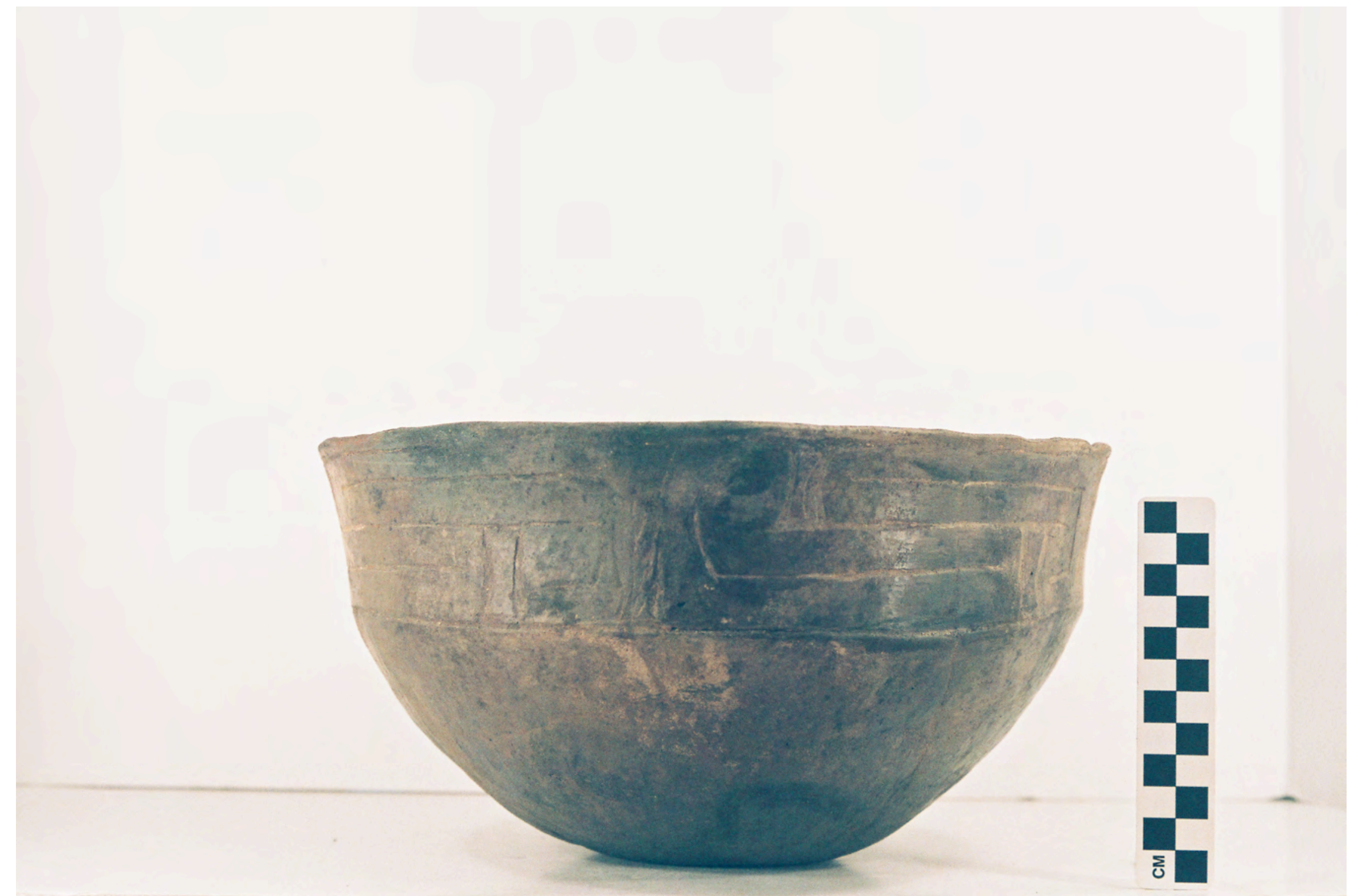

Figure $16 b$ 


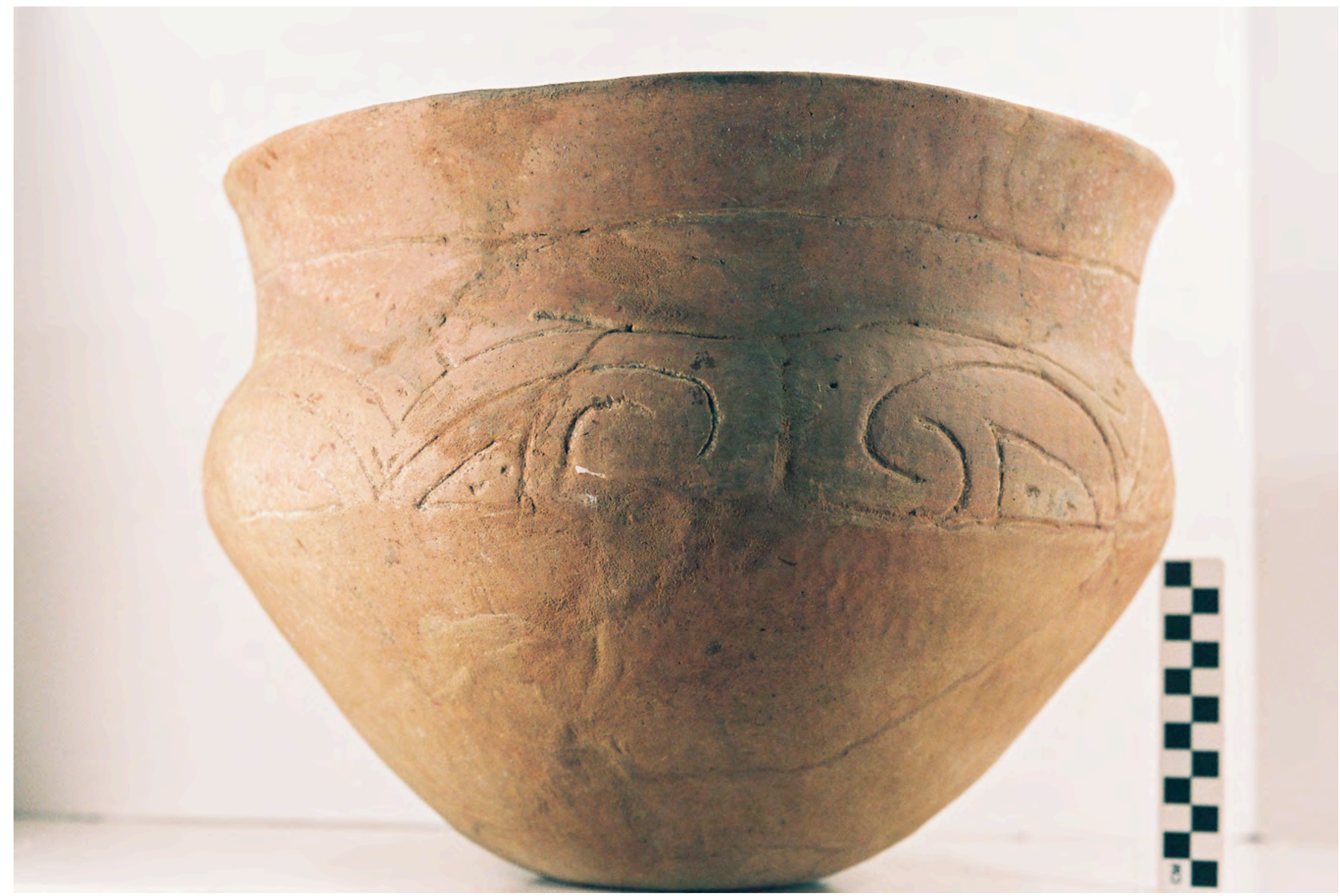

Figure 16c 


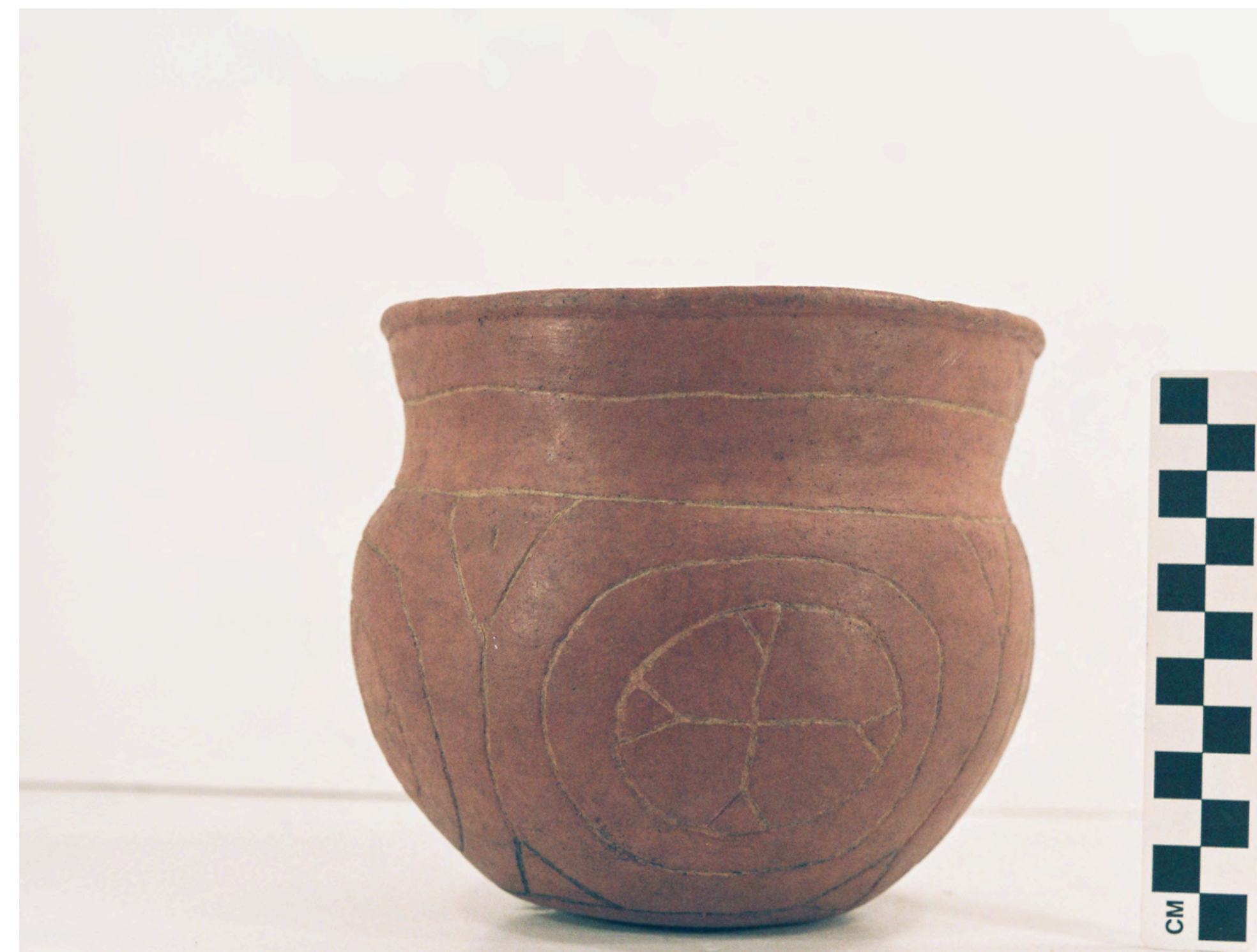

Figure 16d 


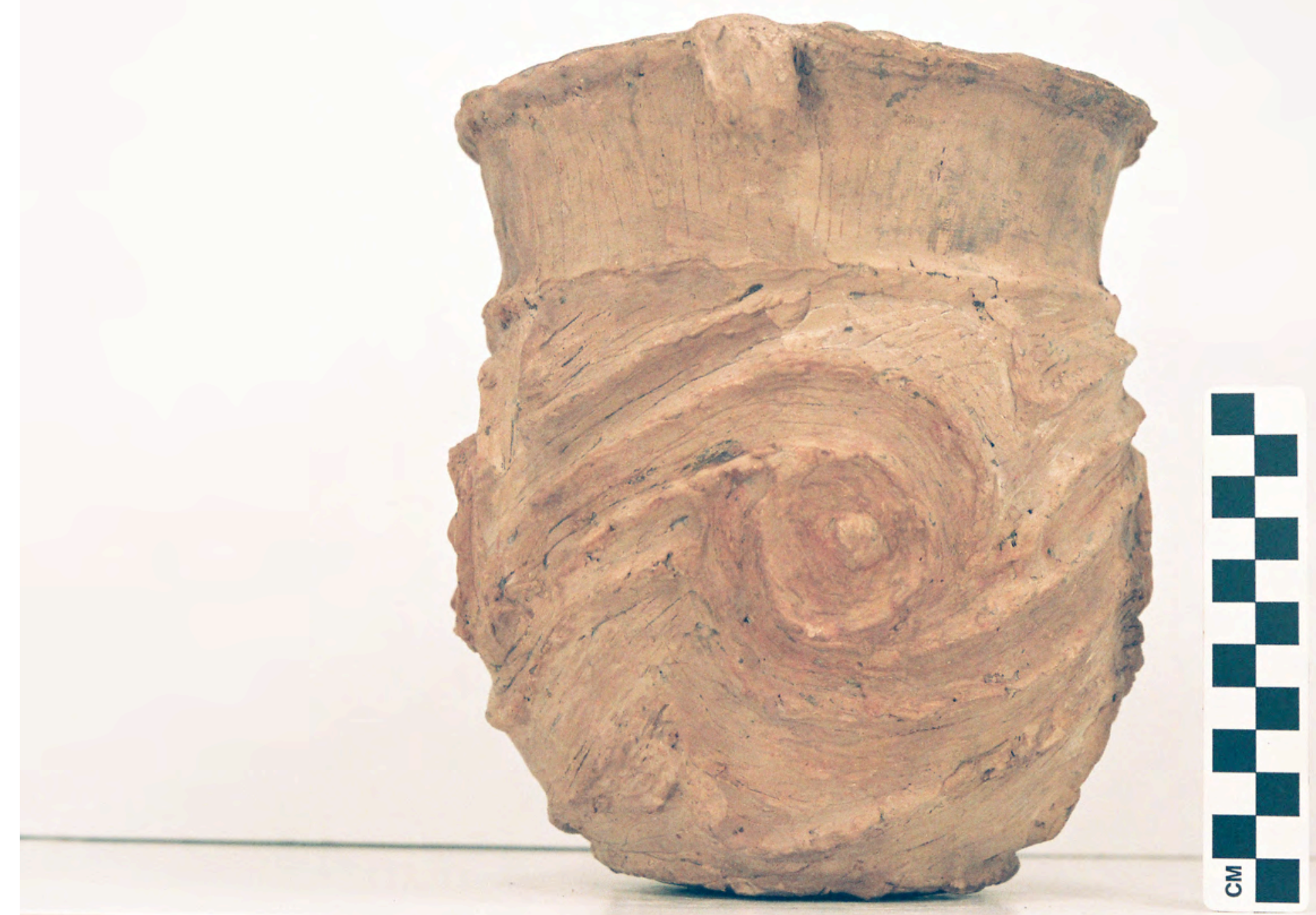

Figure 17a 


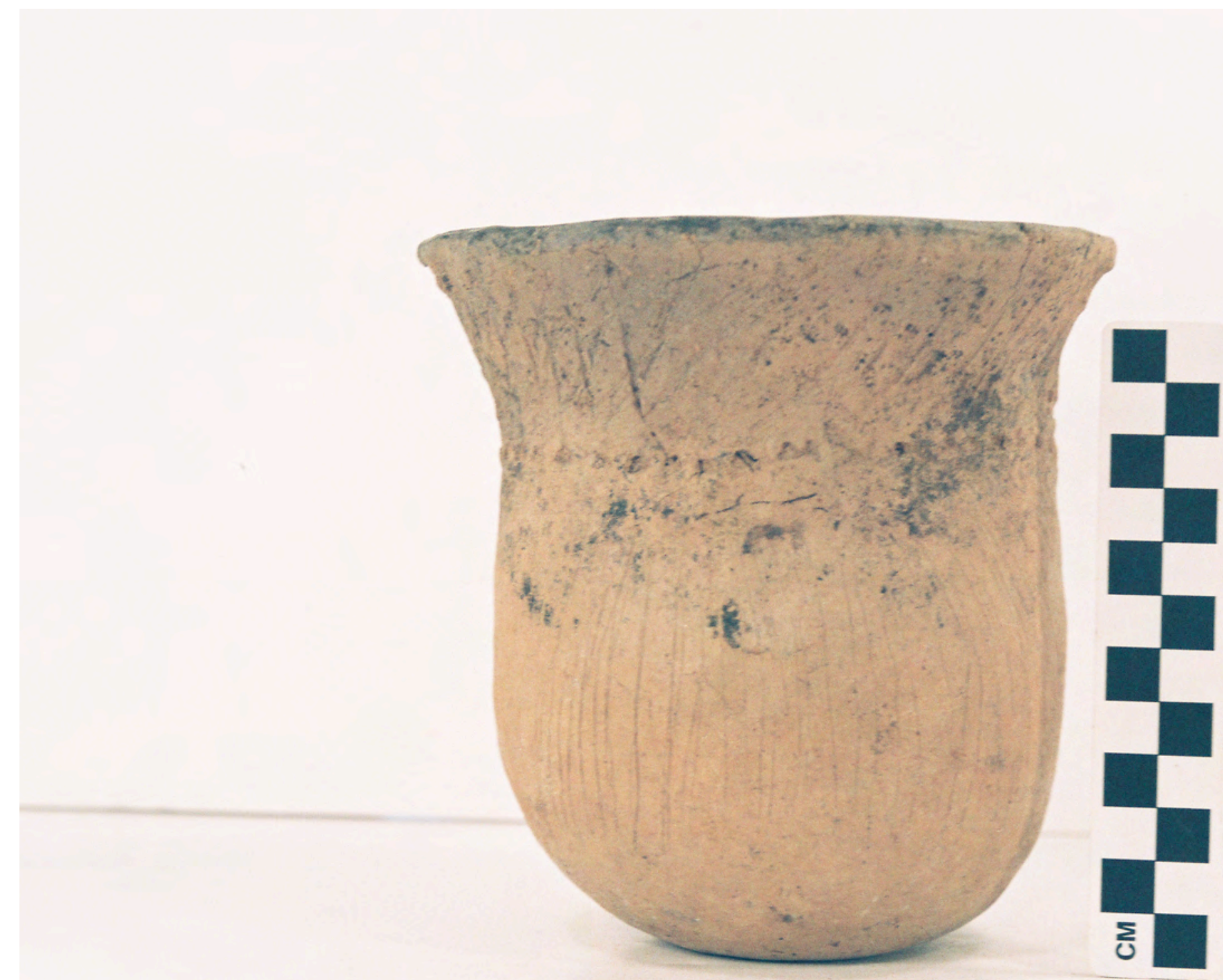

Figure $17 b$ 


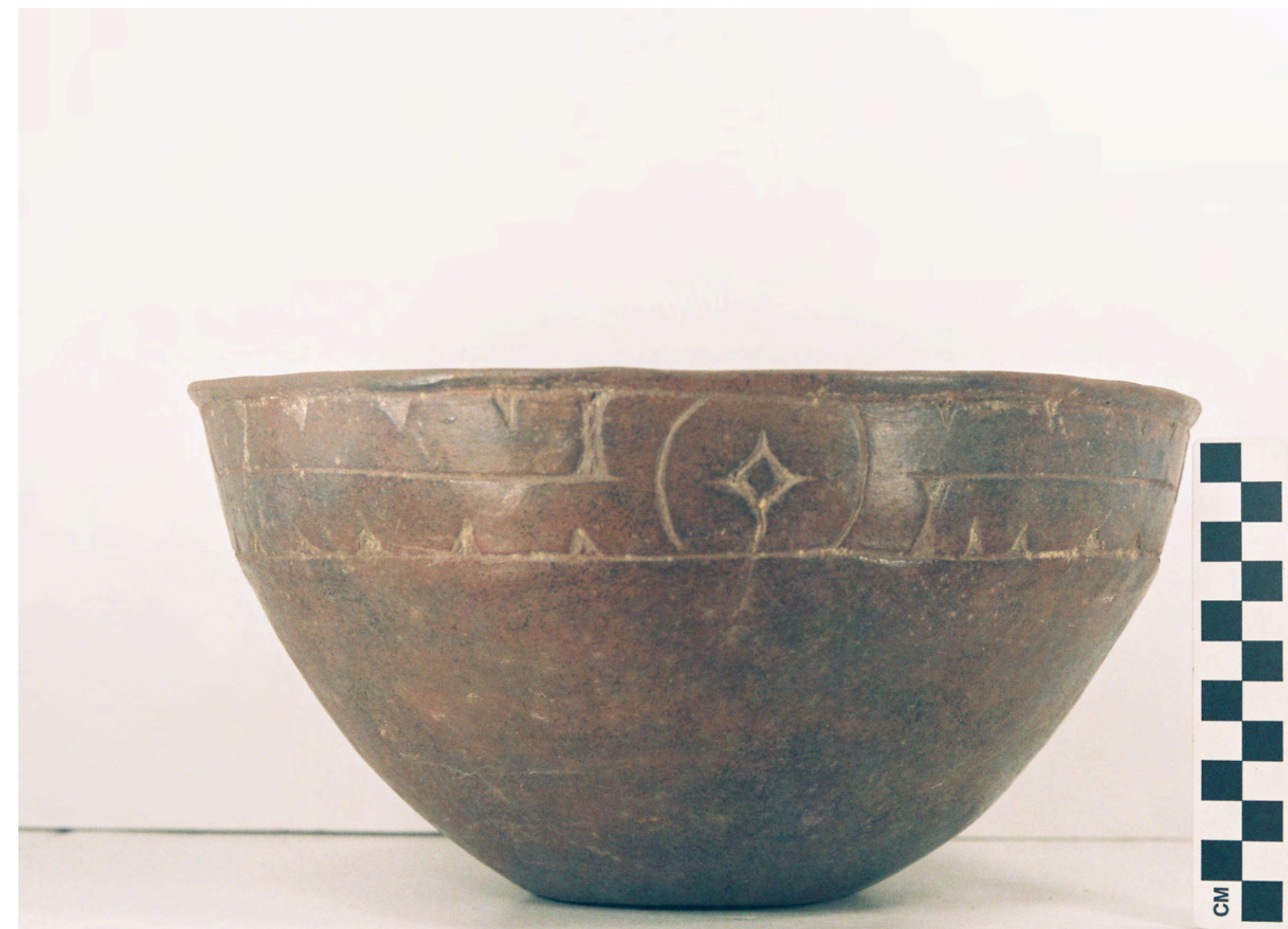

Figure 18a 


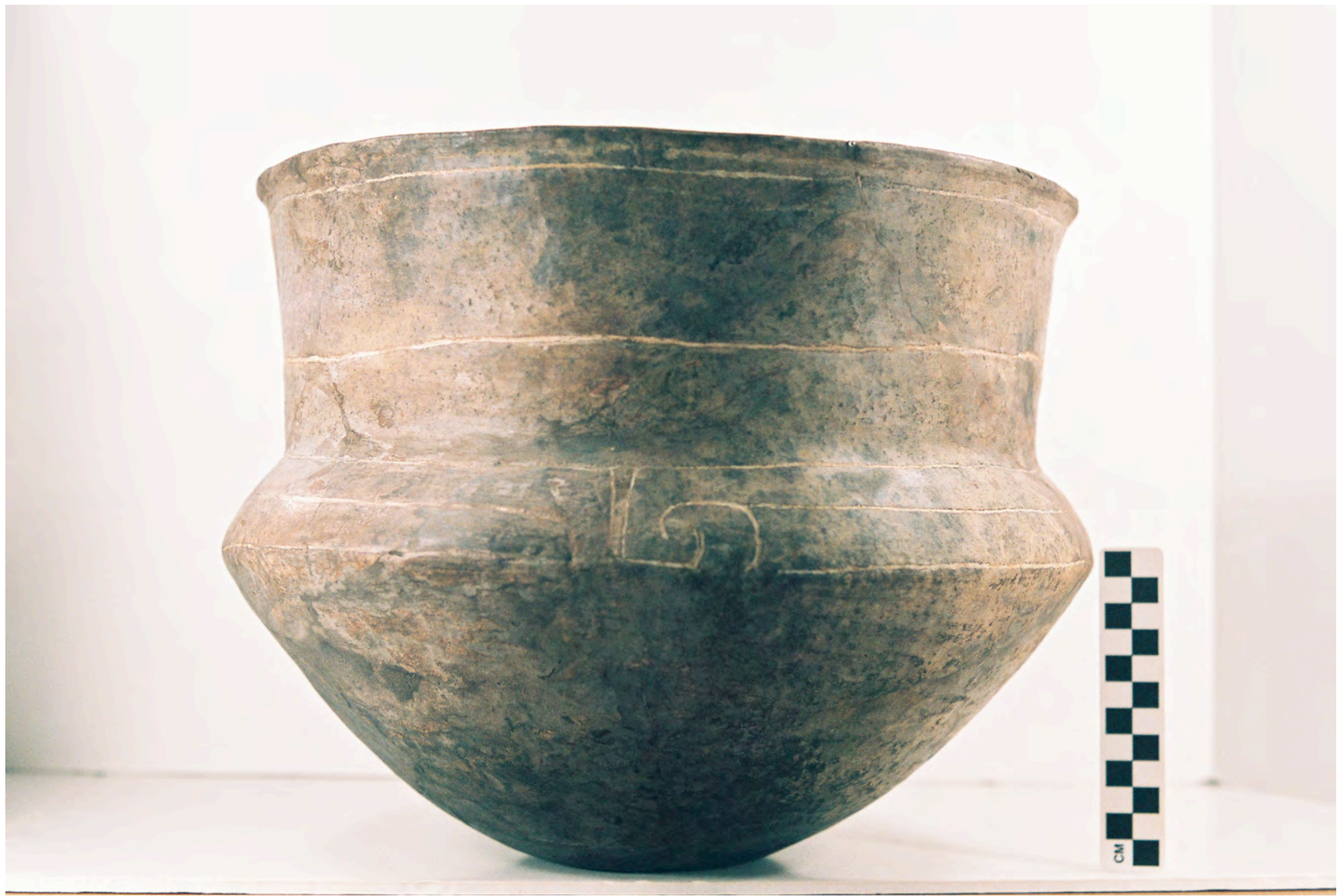

Figure 18b 


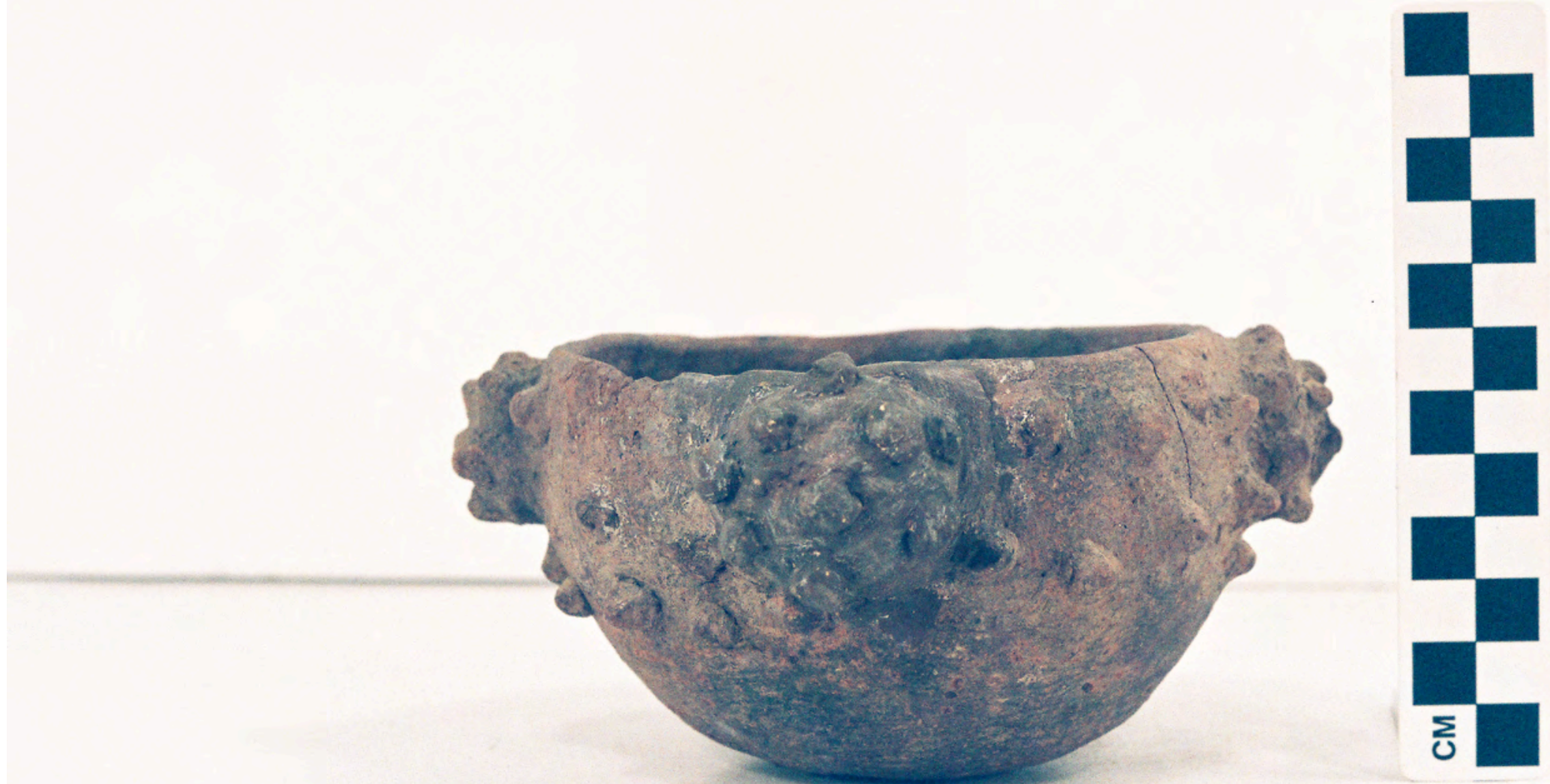

Figure 19 


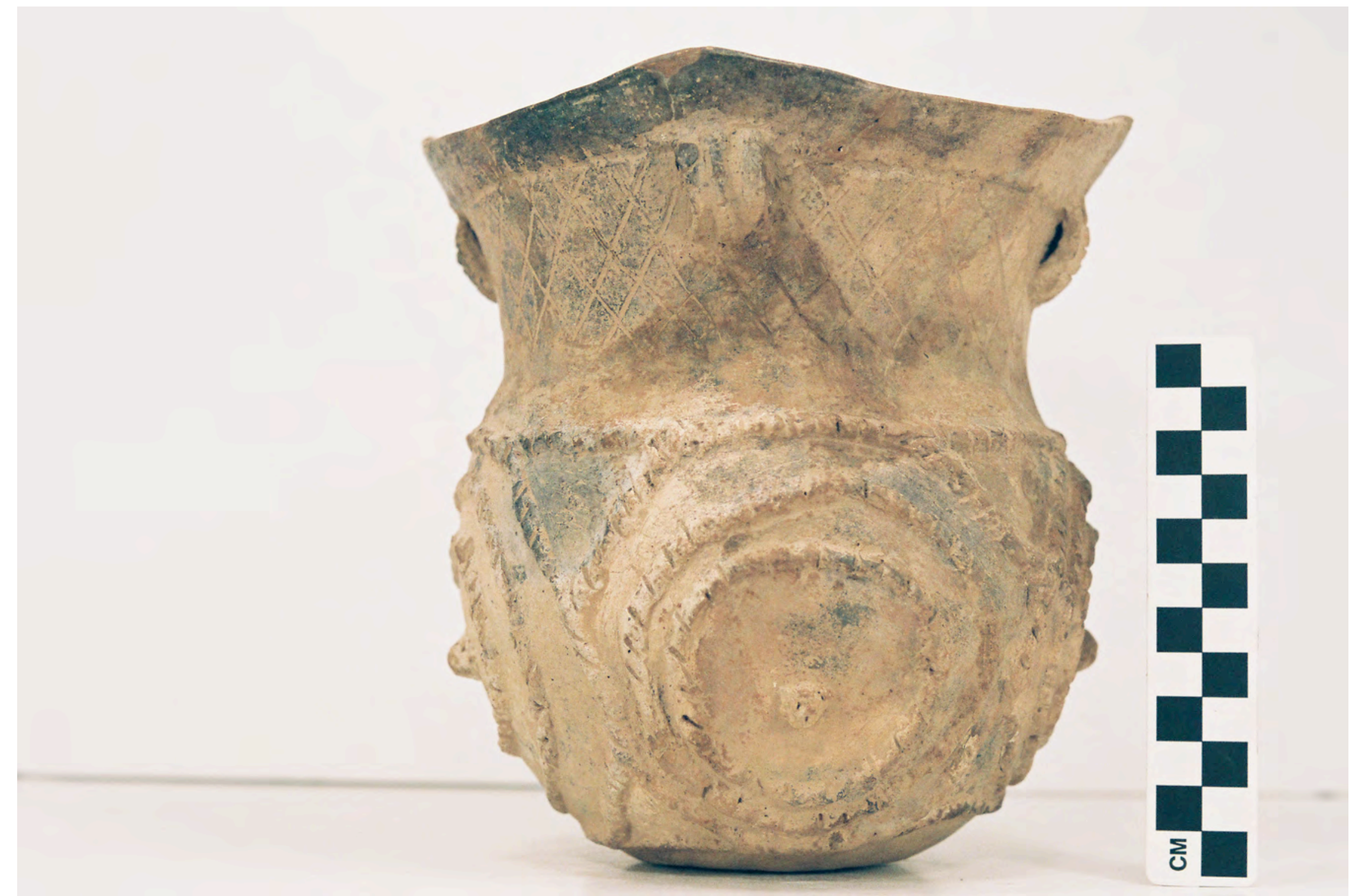

Figure 20a 


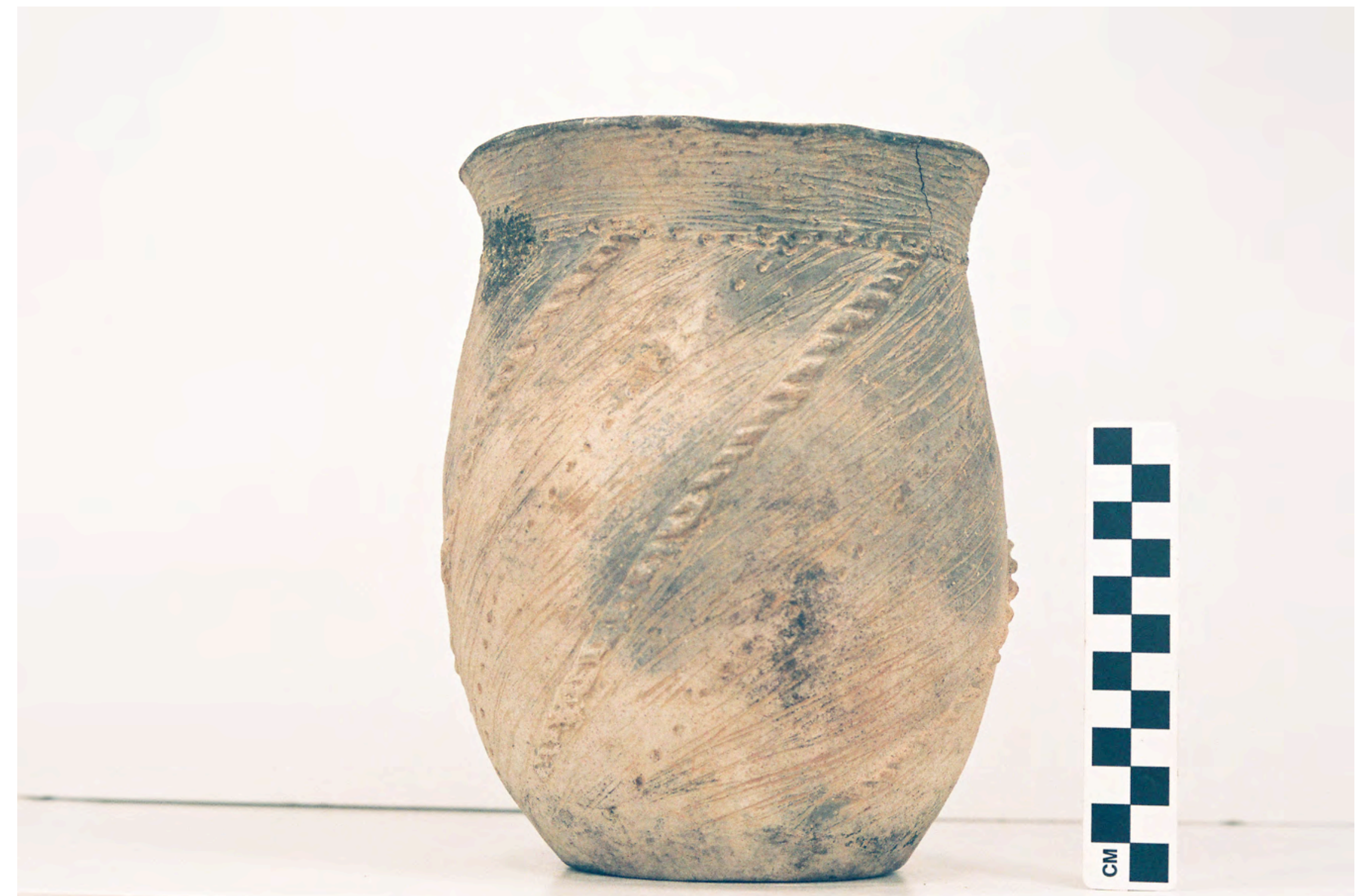

Figure $20 \mathrm{~b}$ 


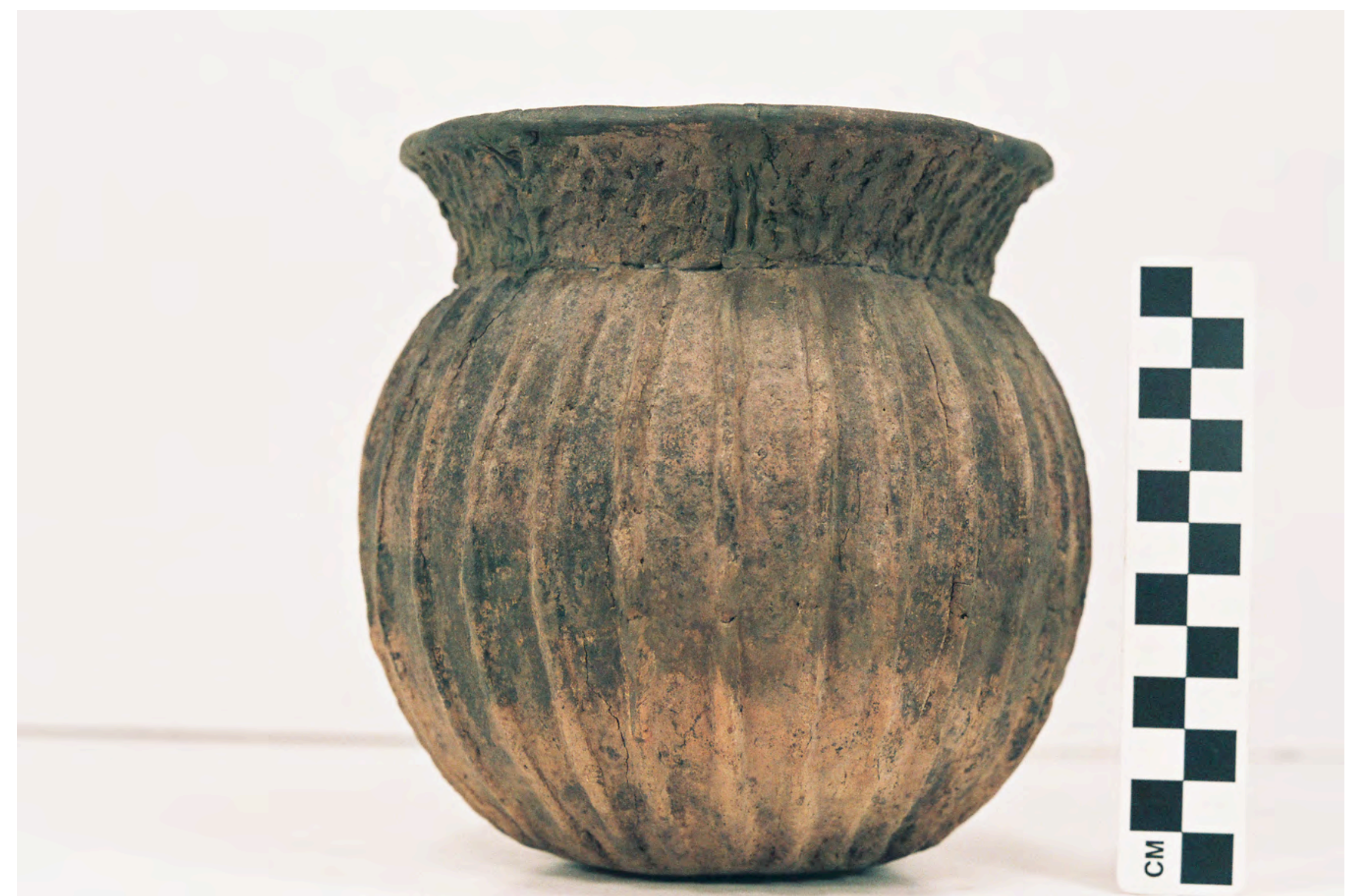

Figure 20c 


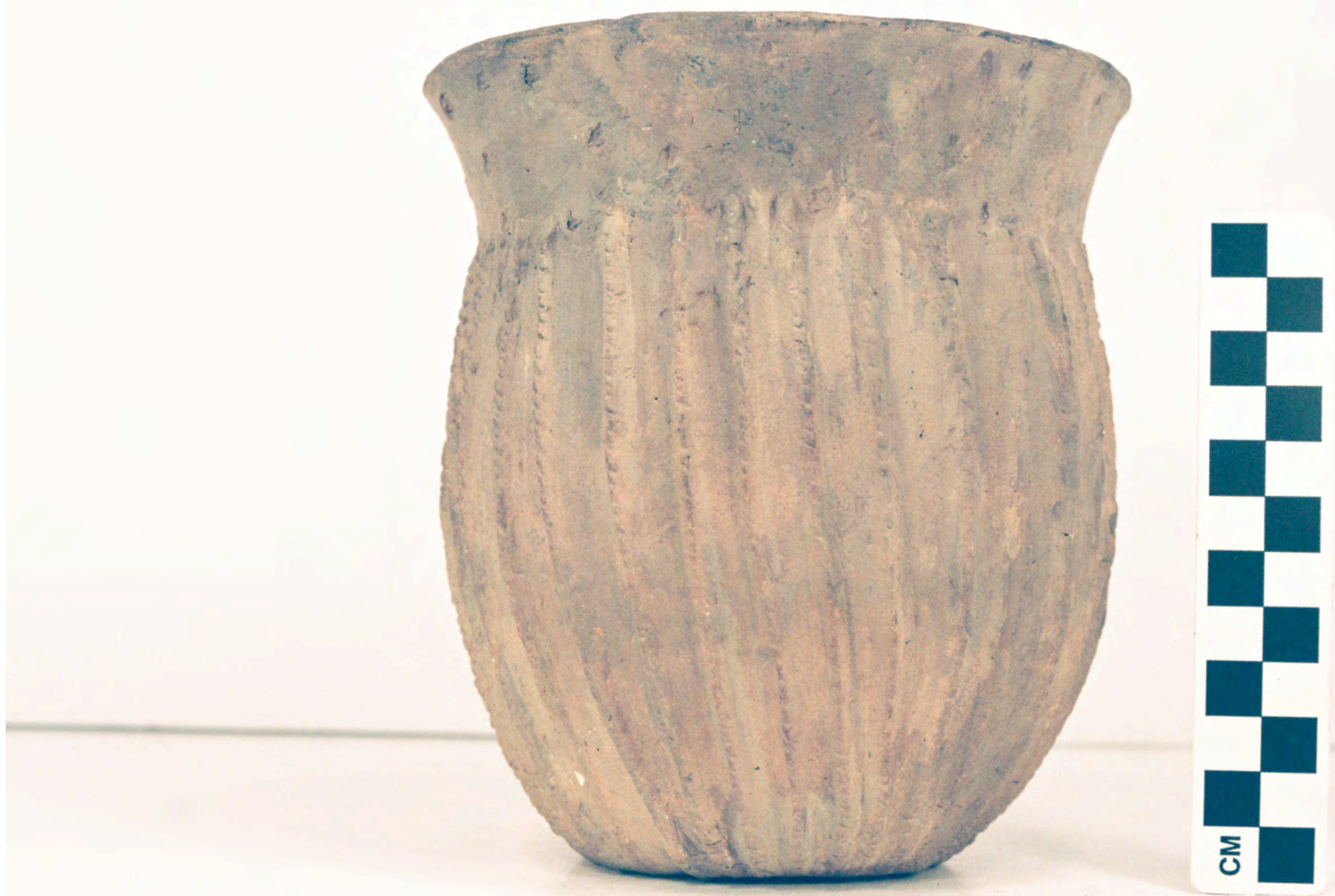

Figure 20d 


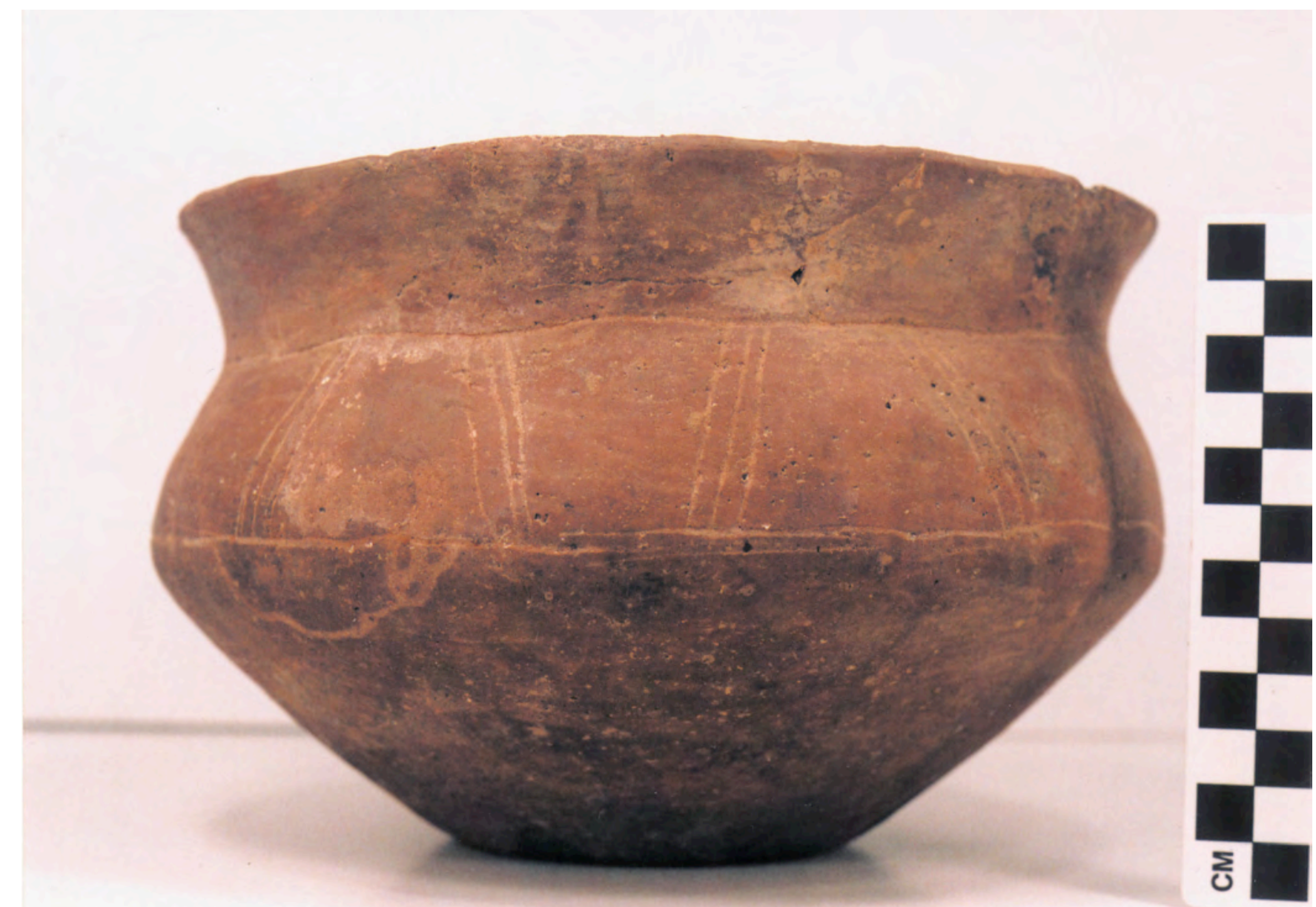

Figure 21a 


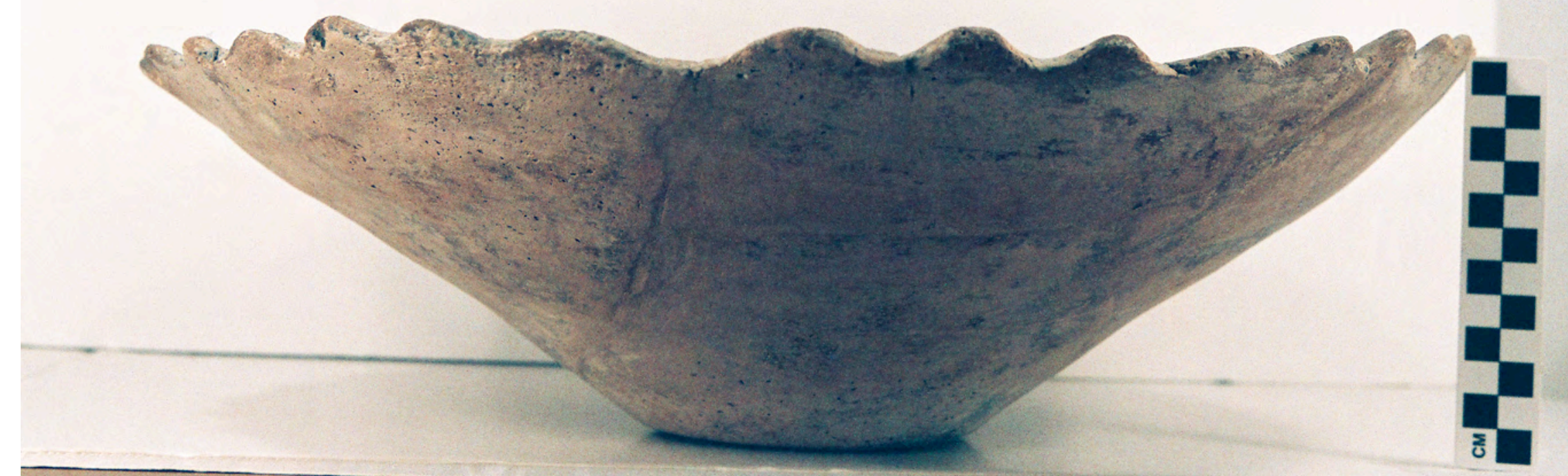

Figure 21b 


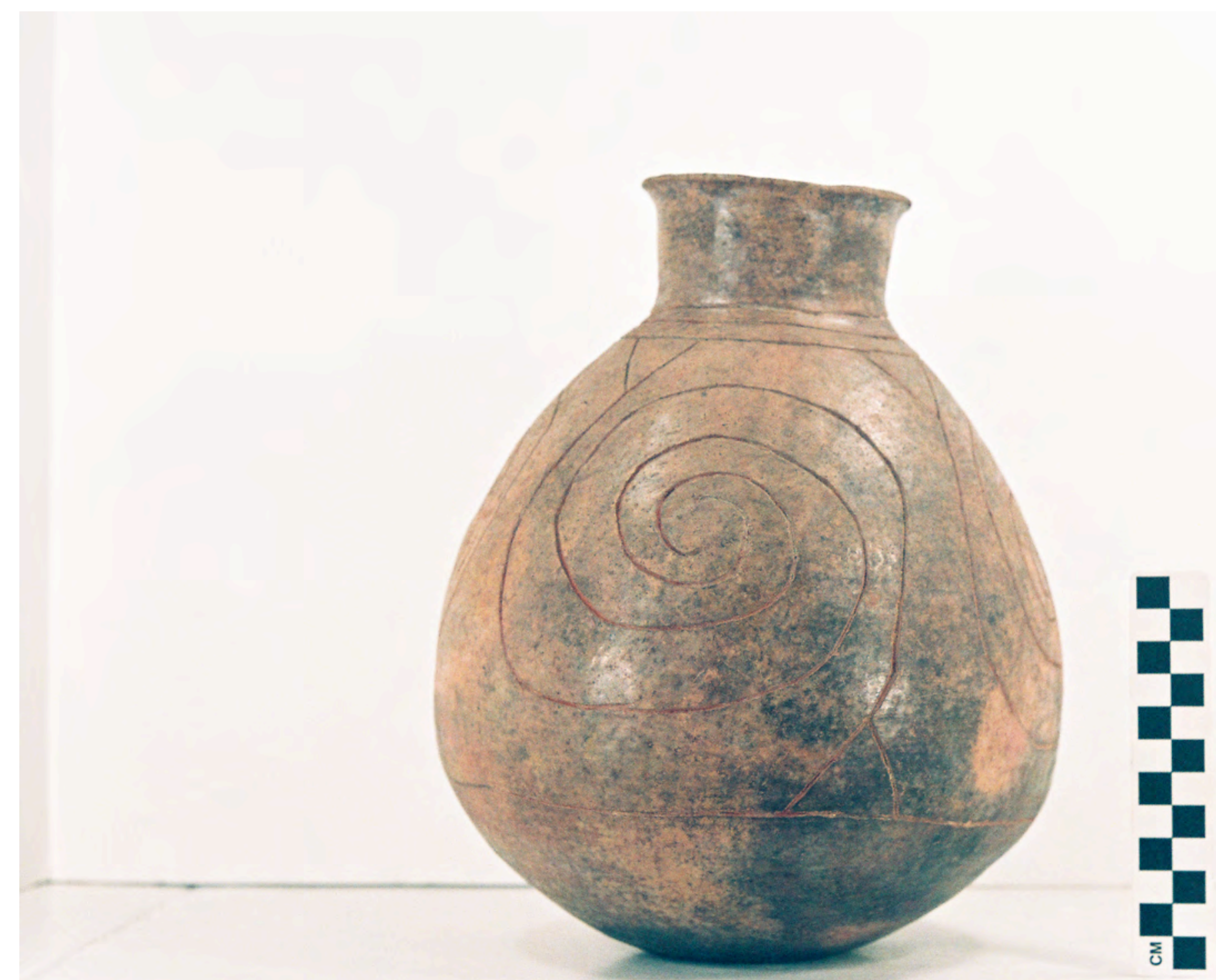

Figure 21c 


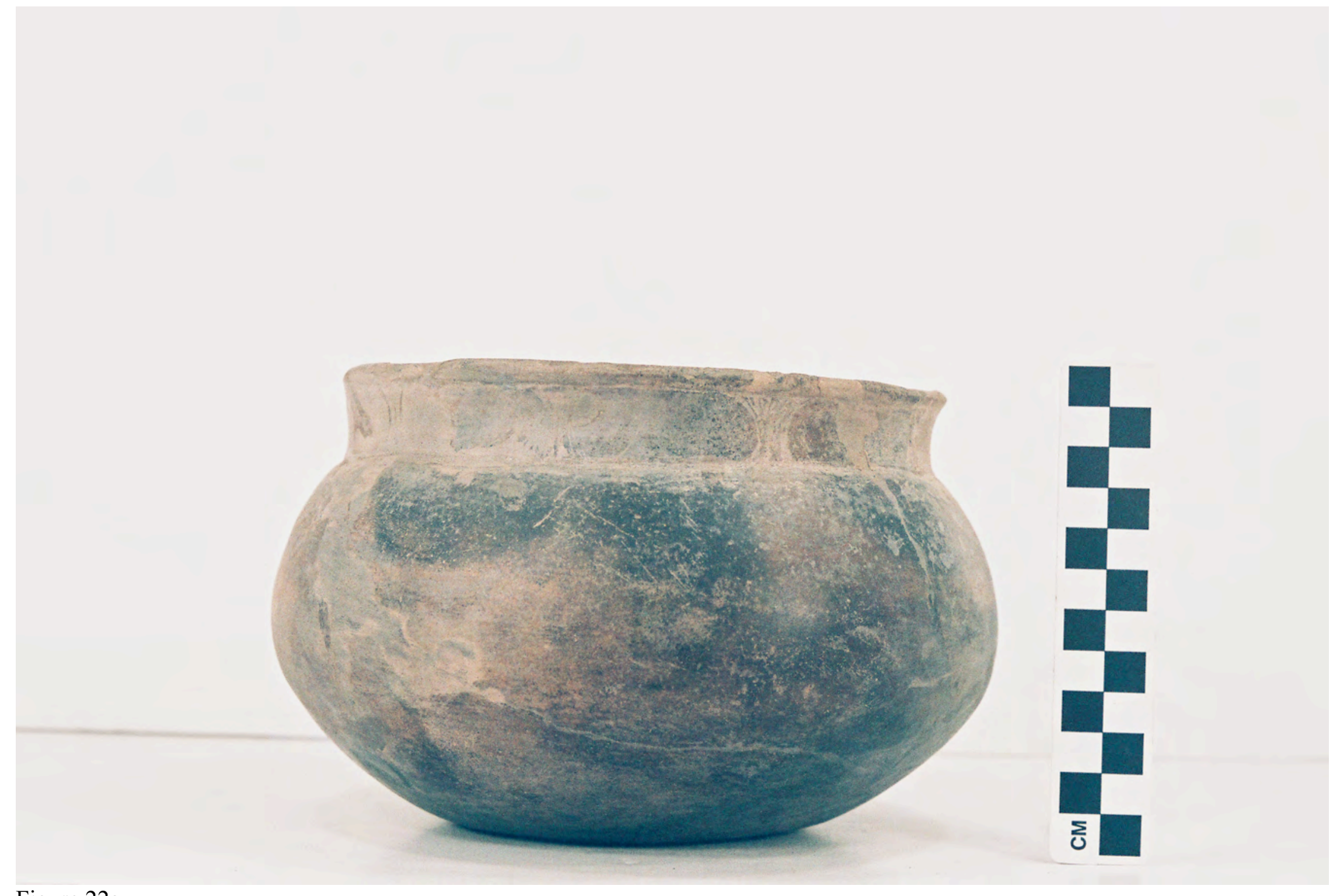

Figure 22a 


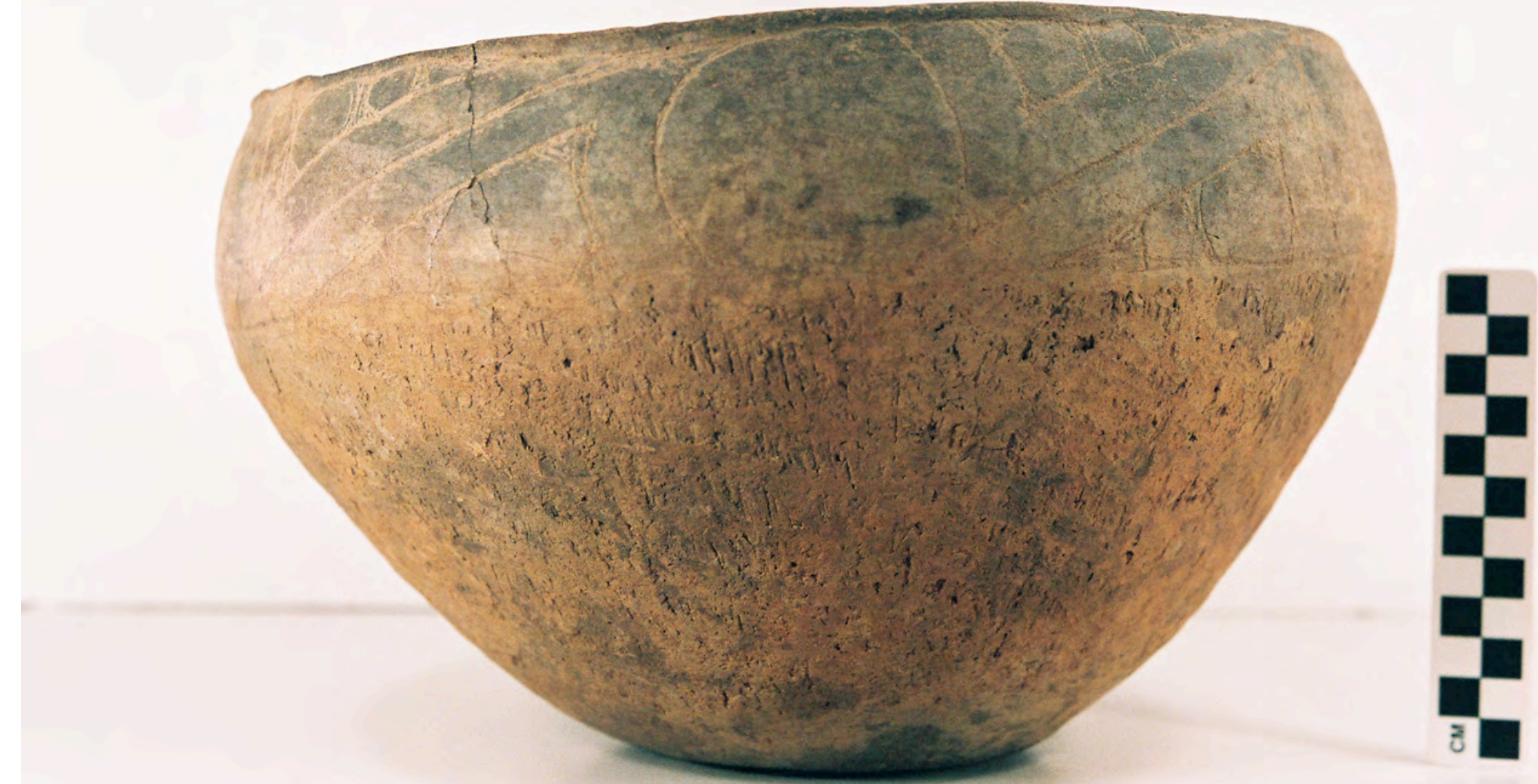

Figure 22b 


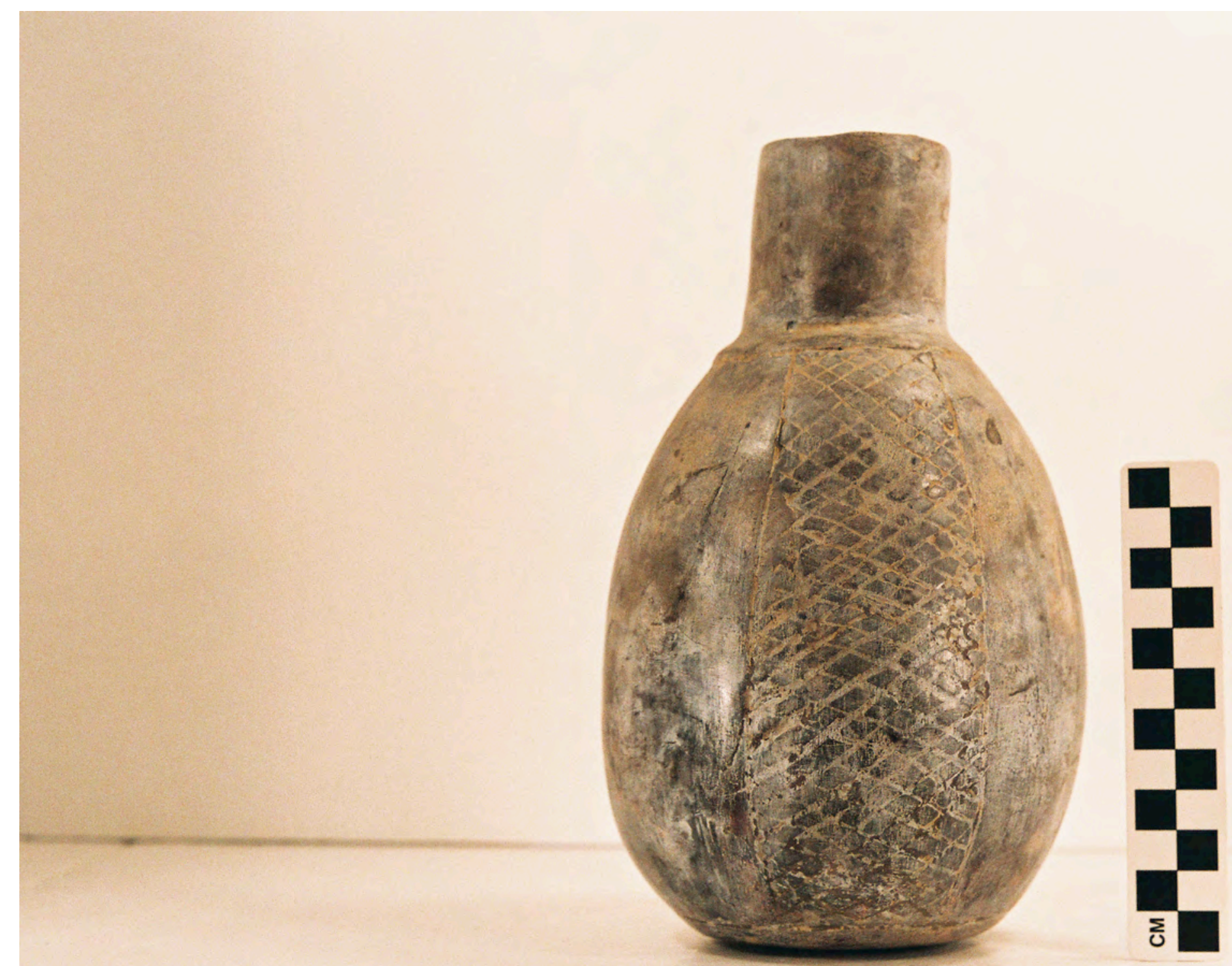

Figure 22c 


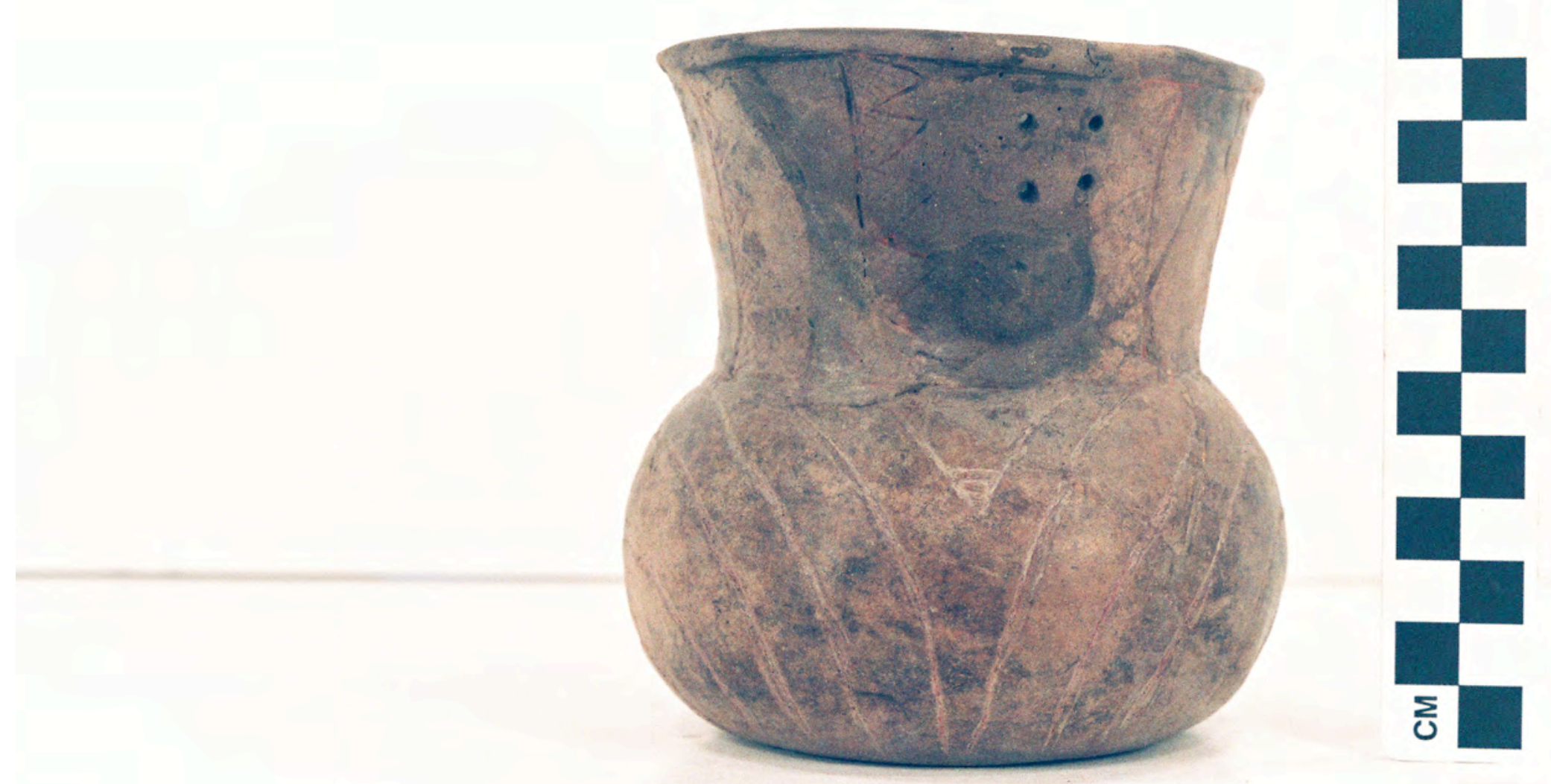

Figure 22d 

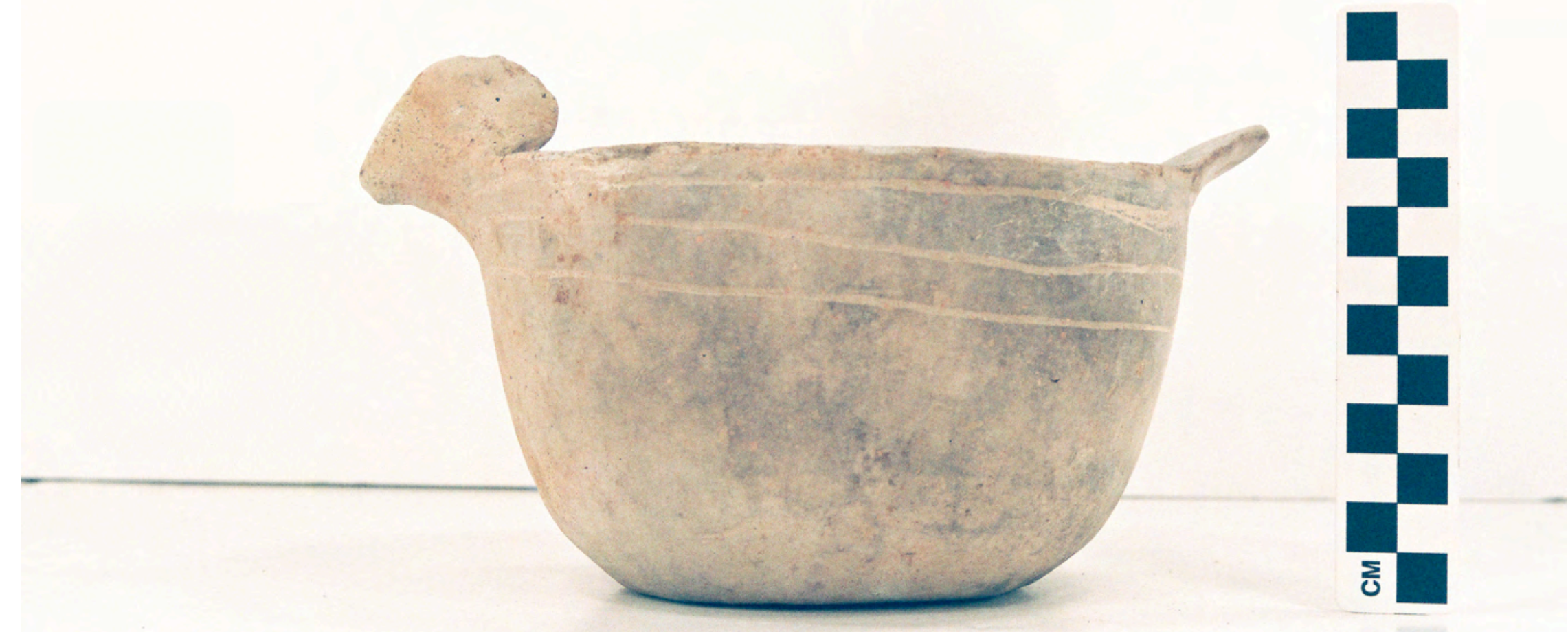

Figure 23a 


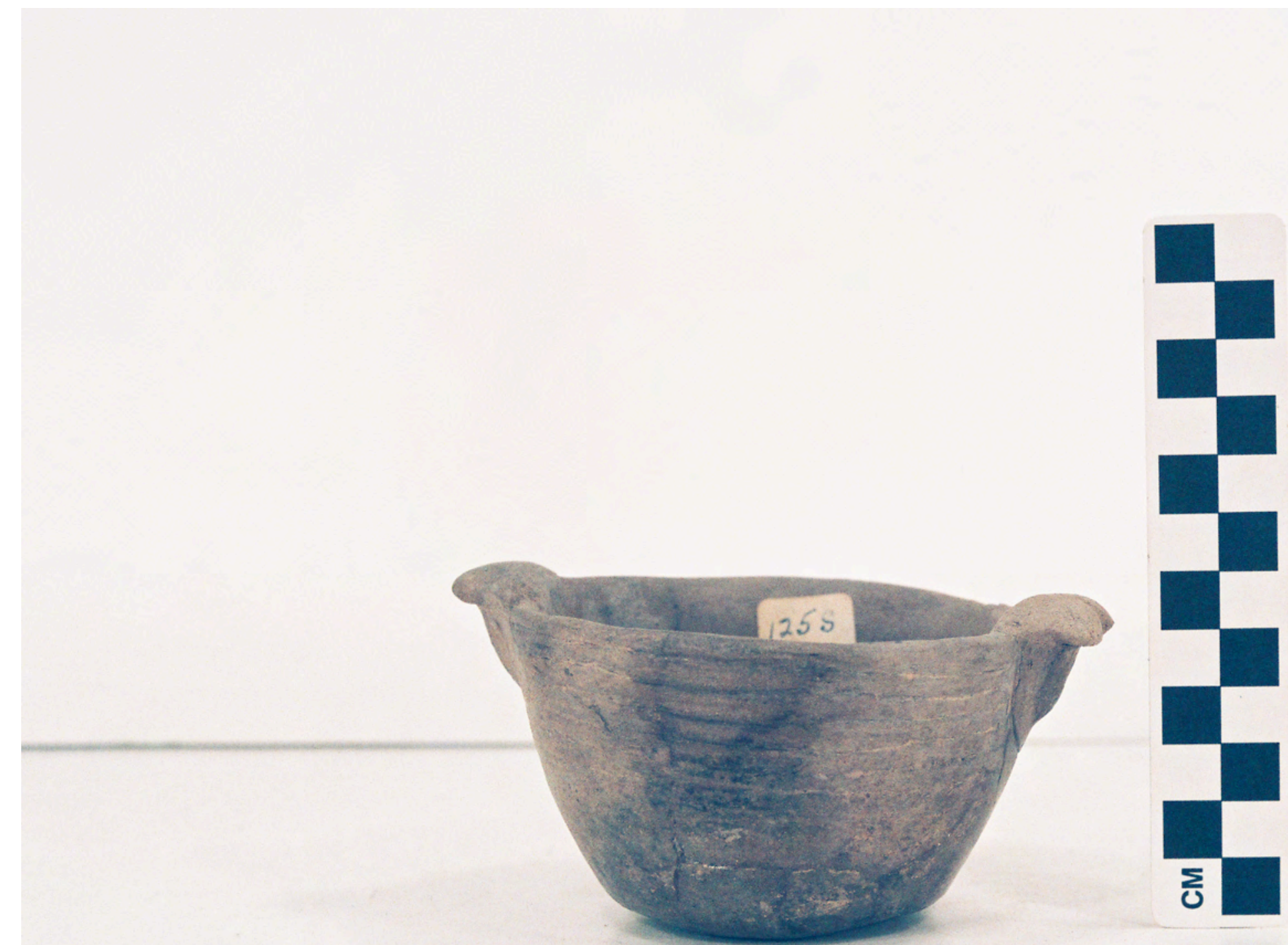

Figure 23b 


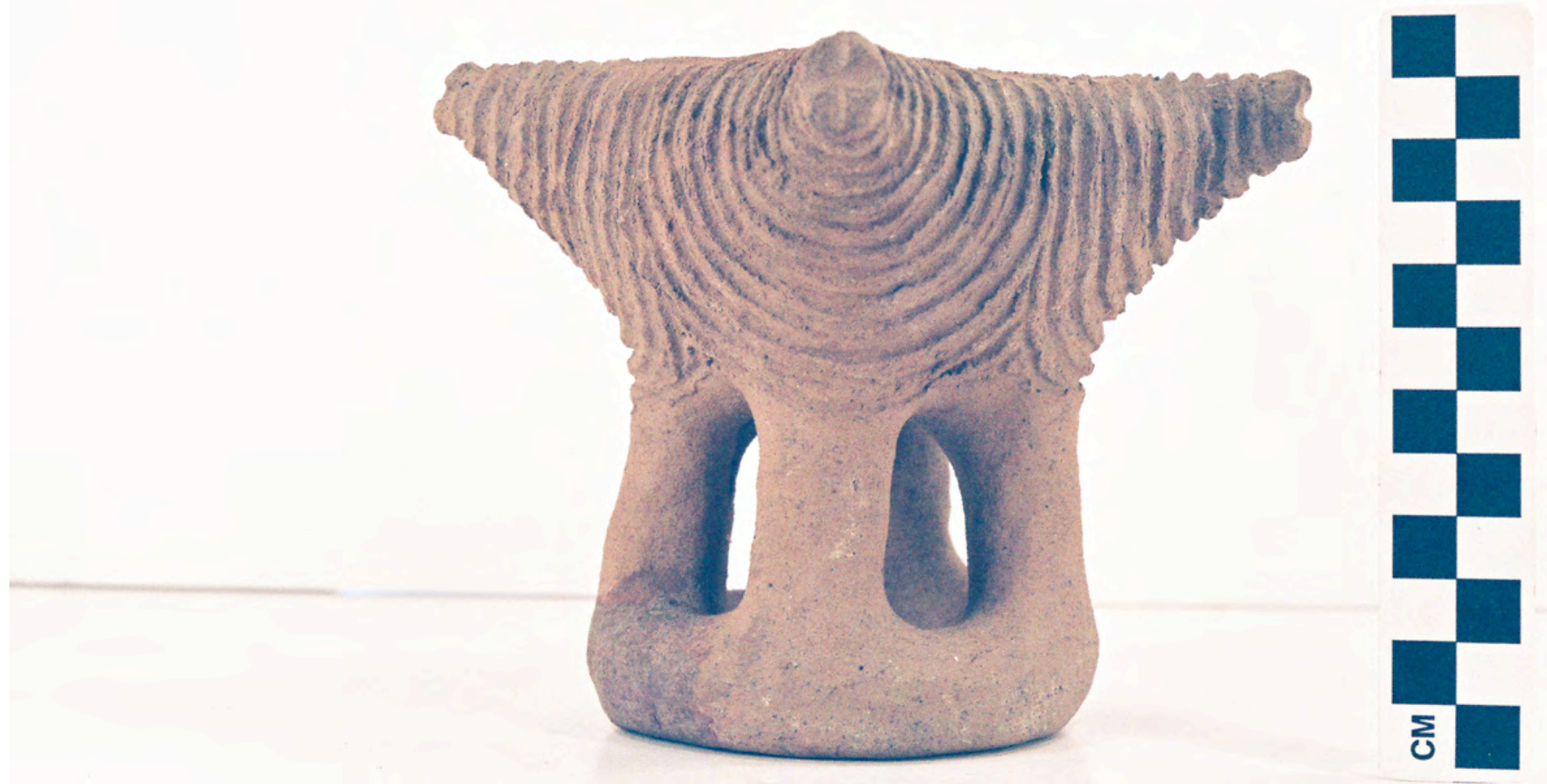

Figure 23c 


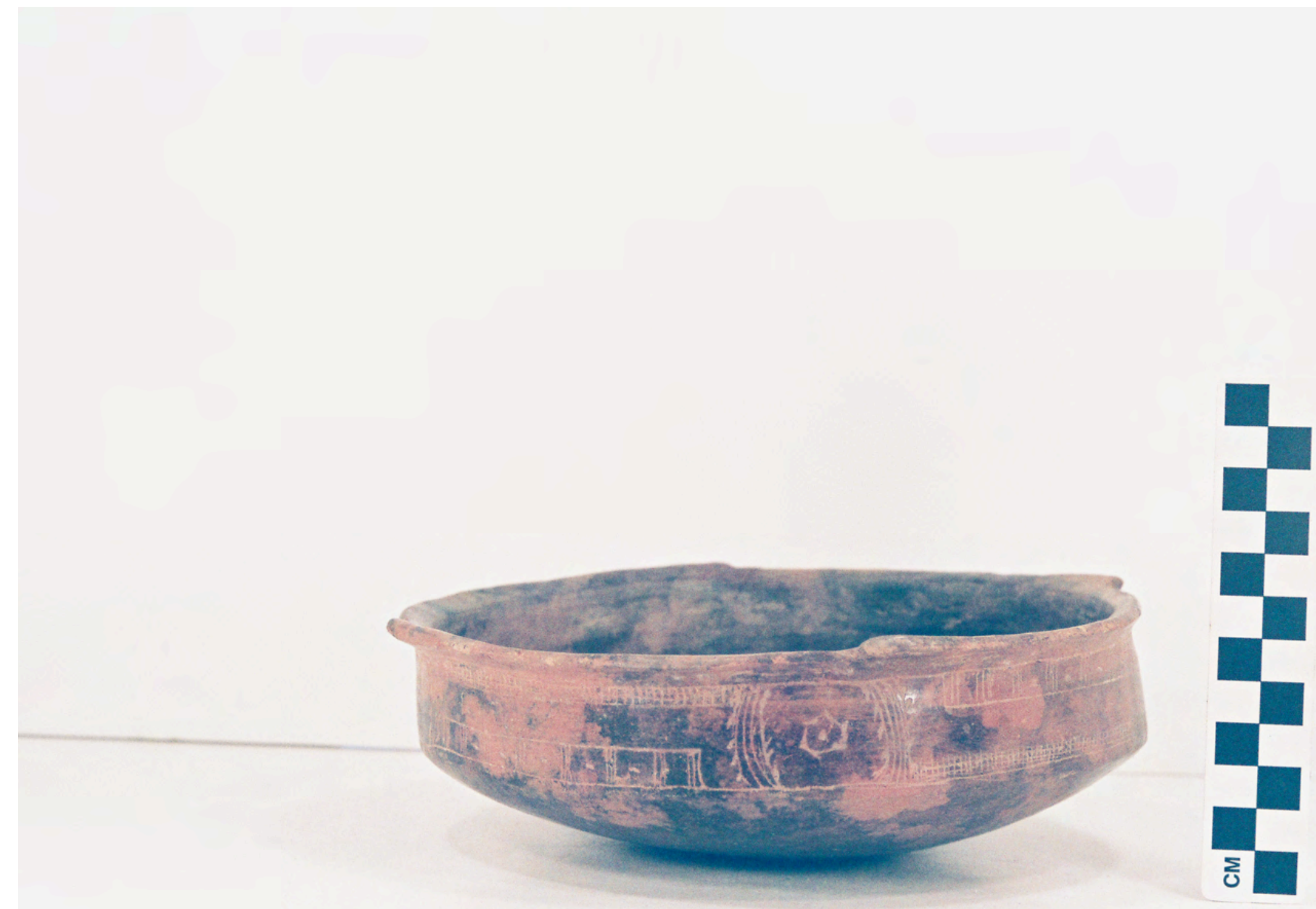

Figure 24a 


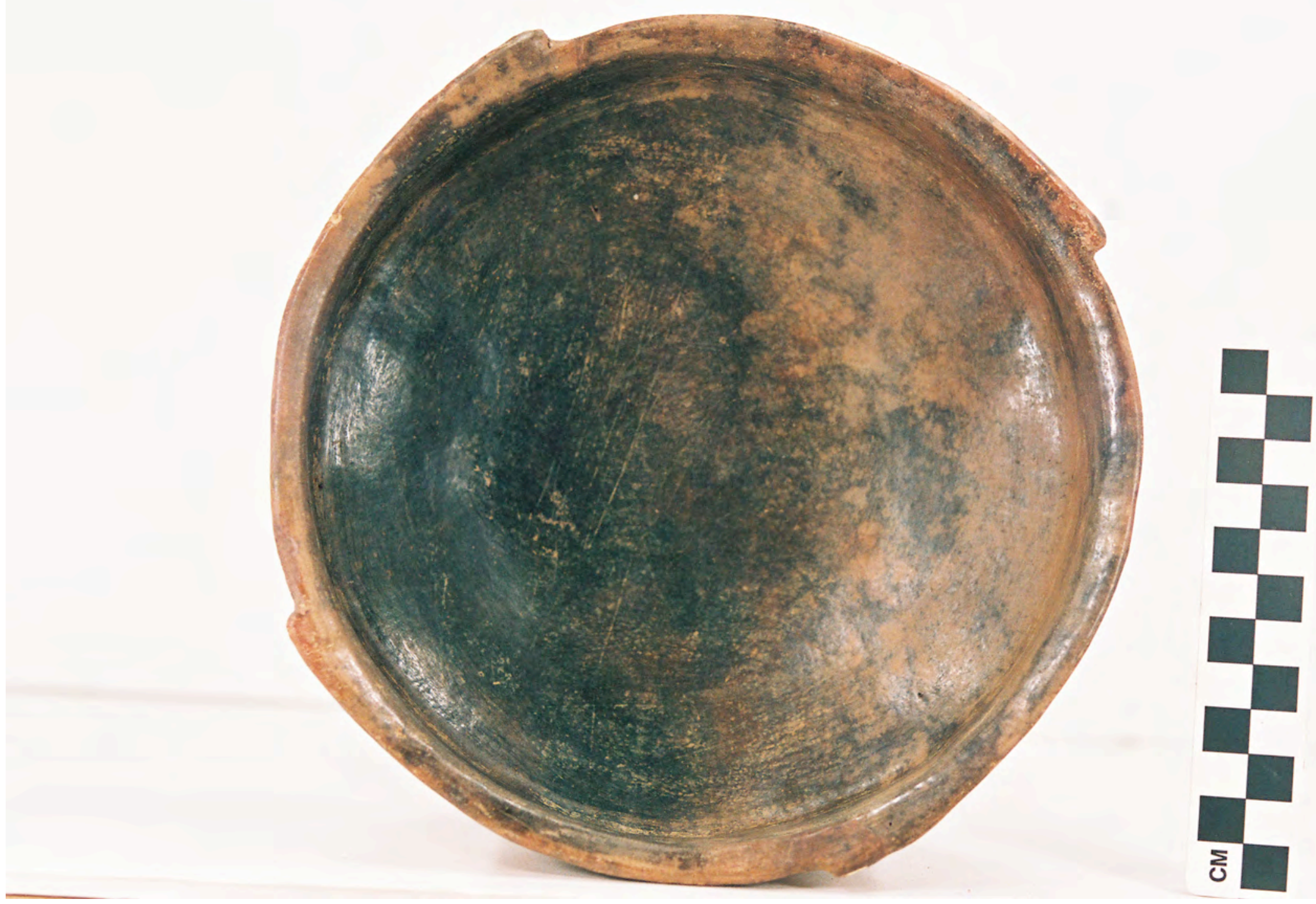

Figure 24b 


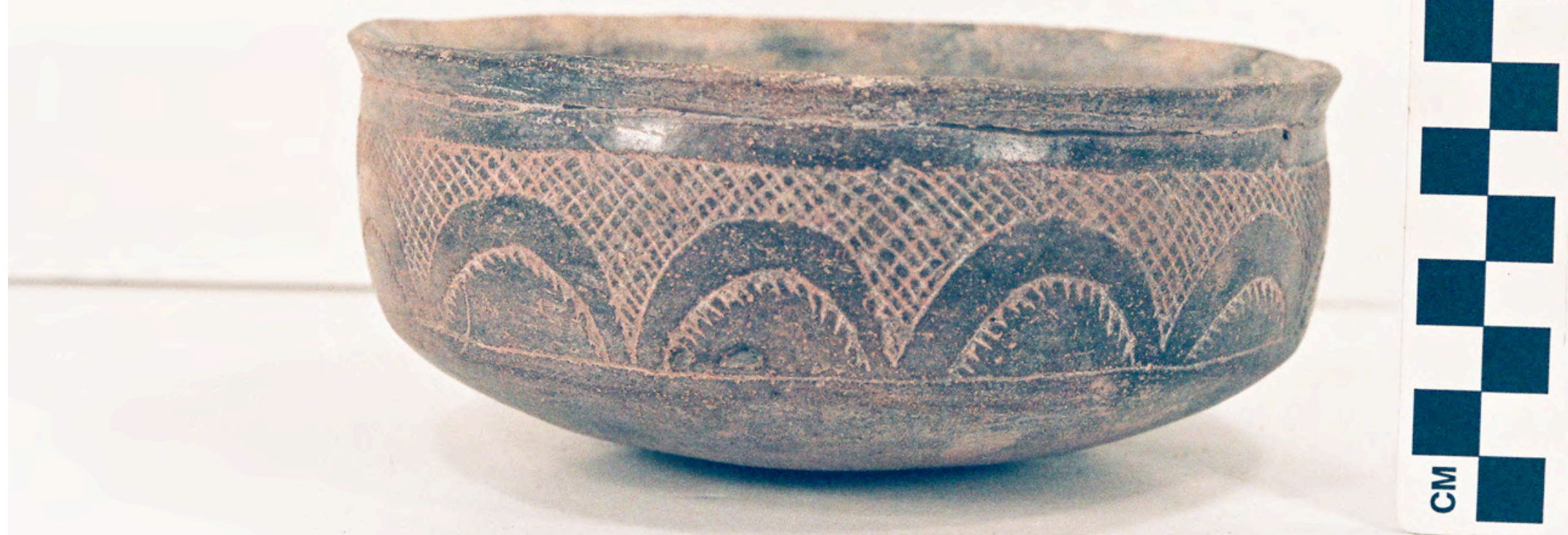

Figure 24c 


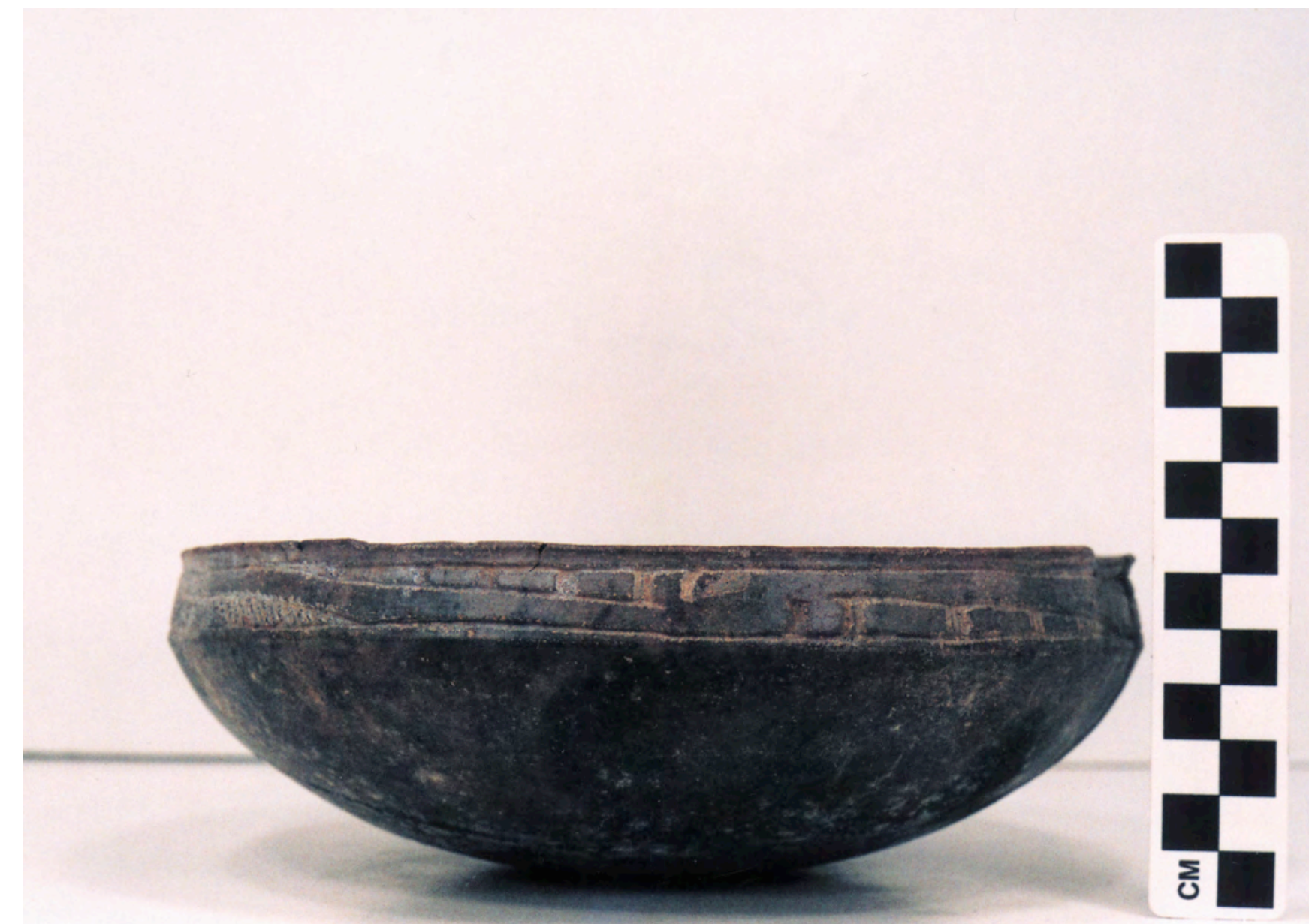

Figure 24d 


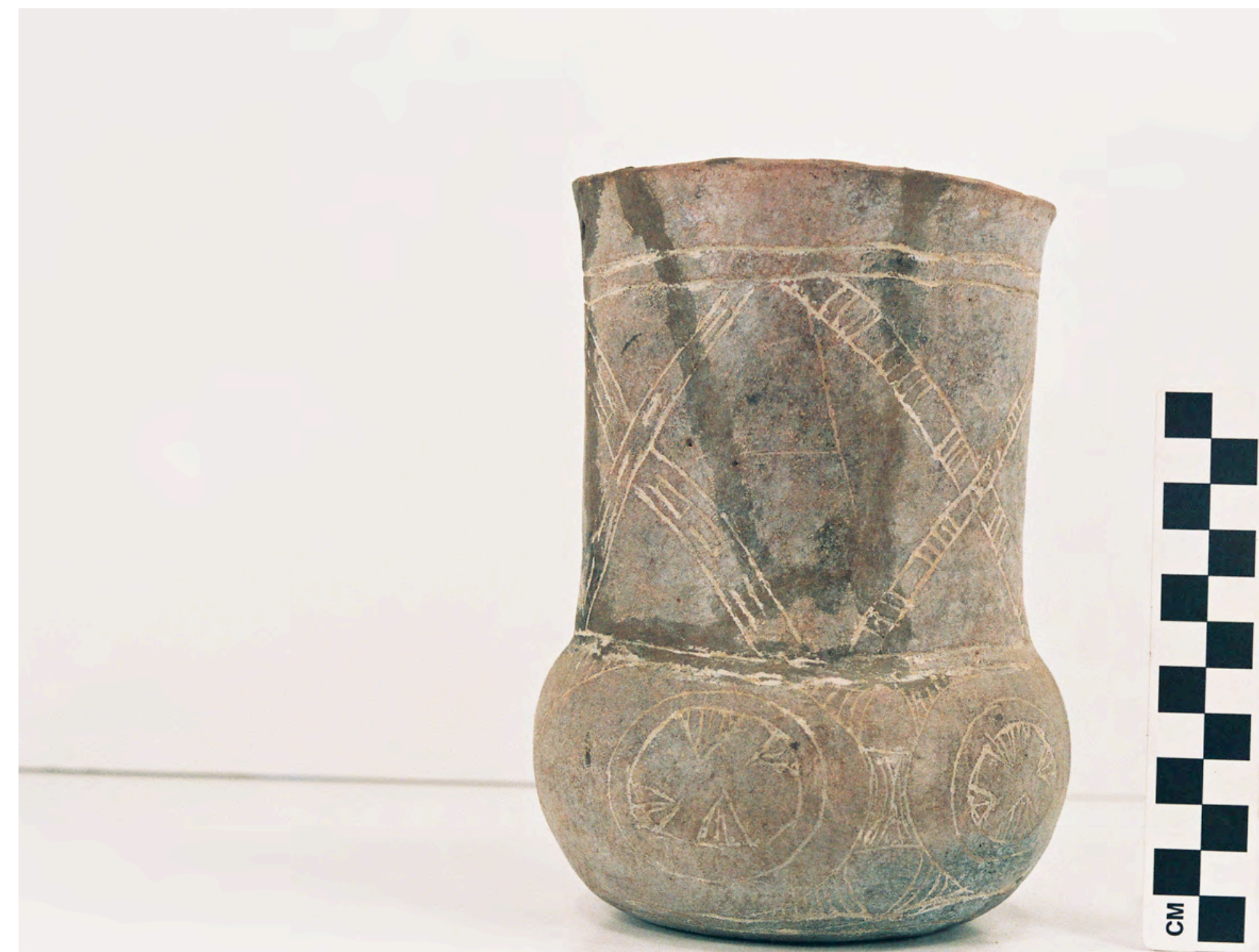

Figure $24 \mathrm{e}$ 


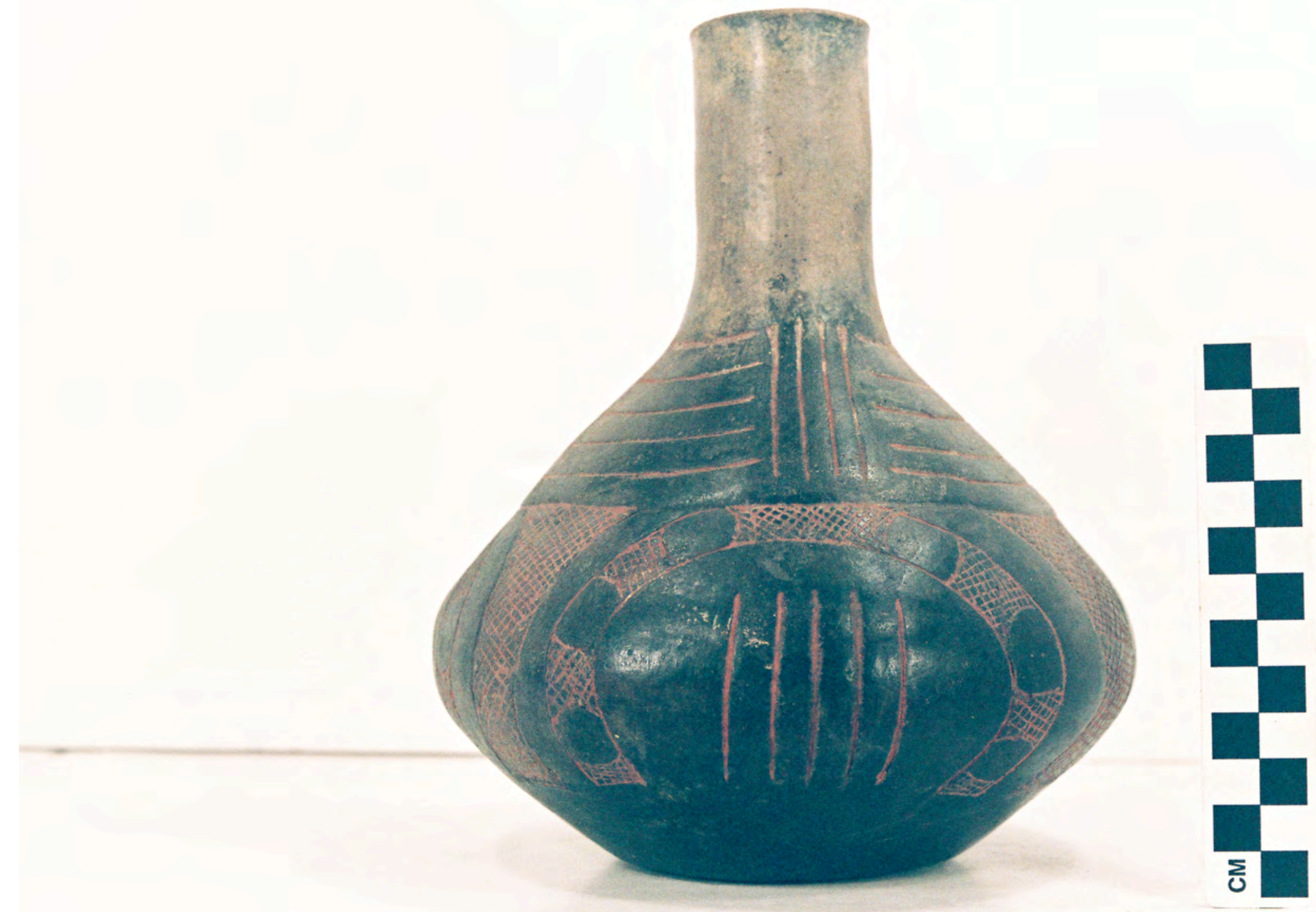

Figure 25a 


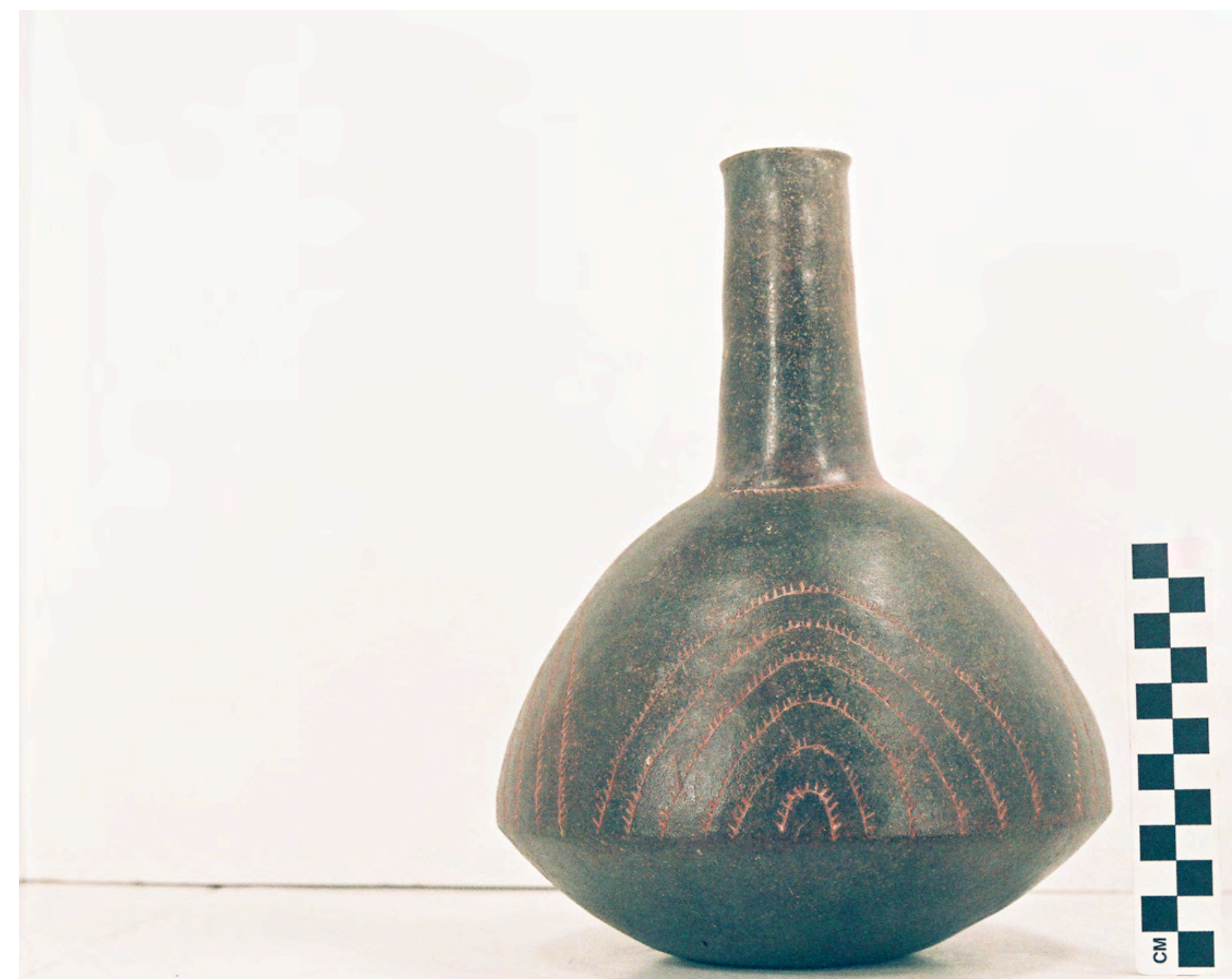

Figure 25b 


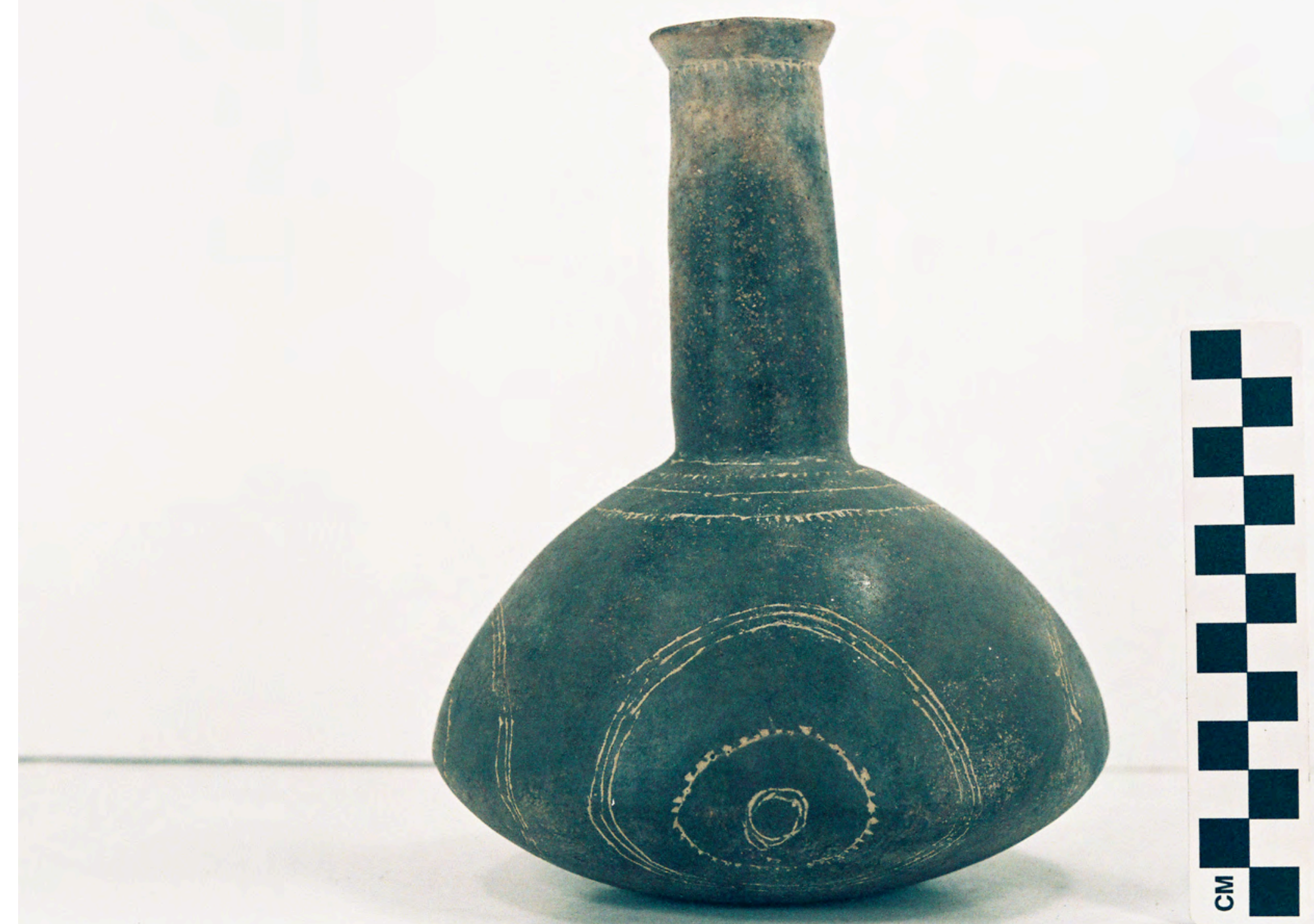

Figure 25c 


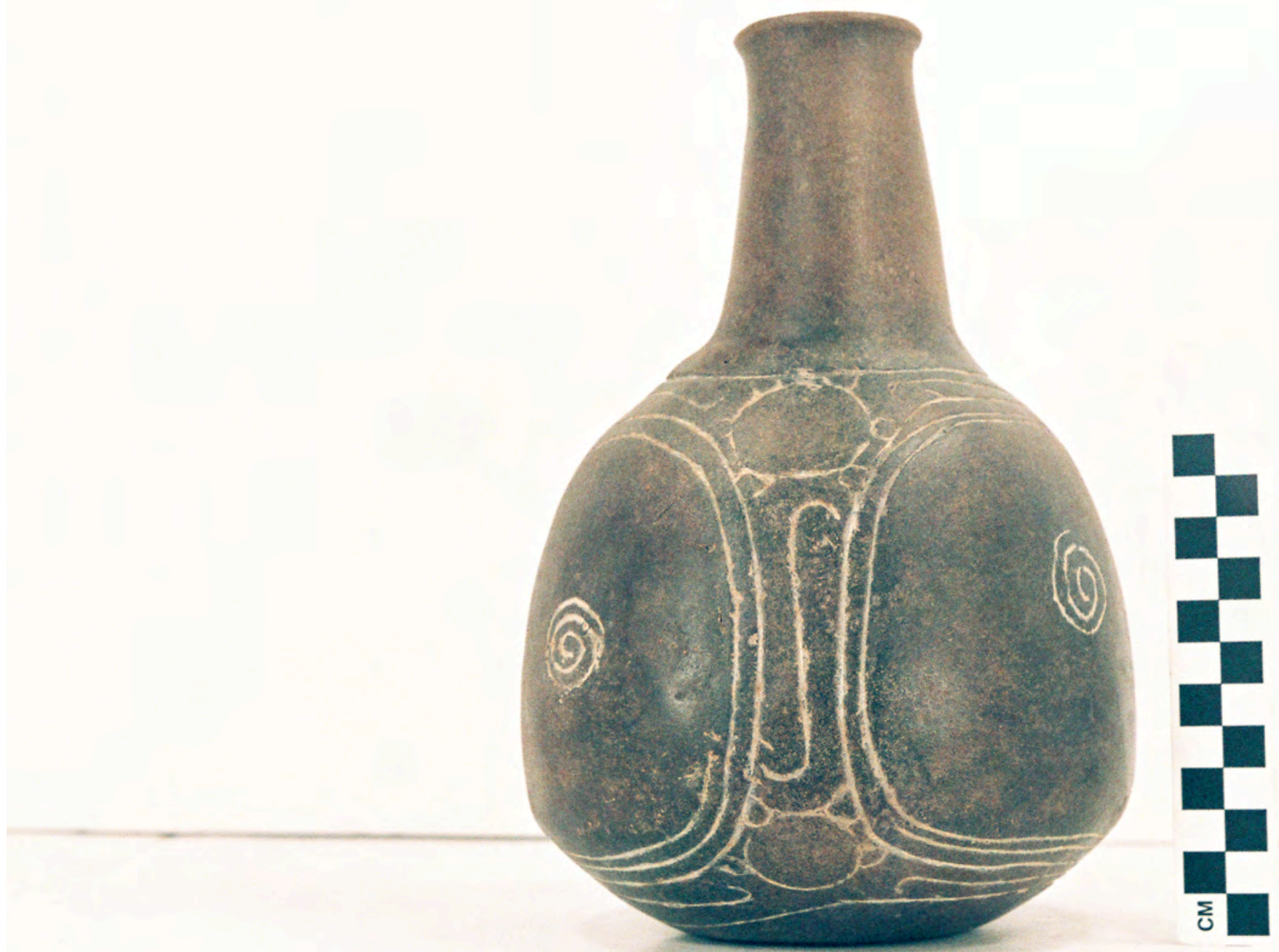

Figure 25d 


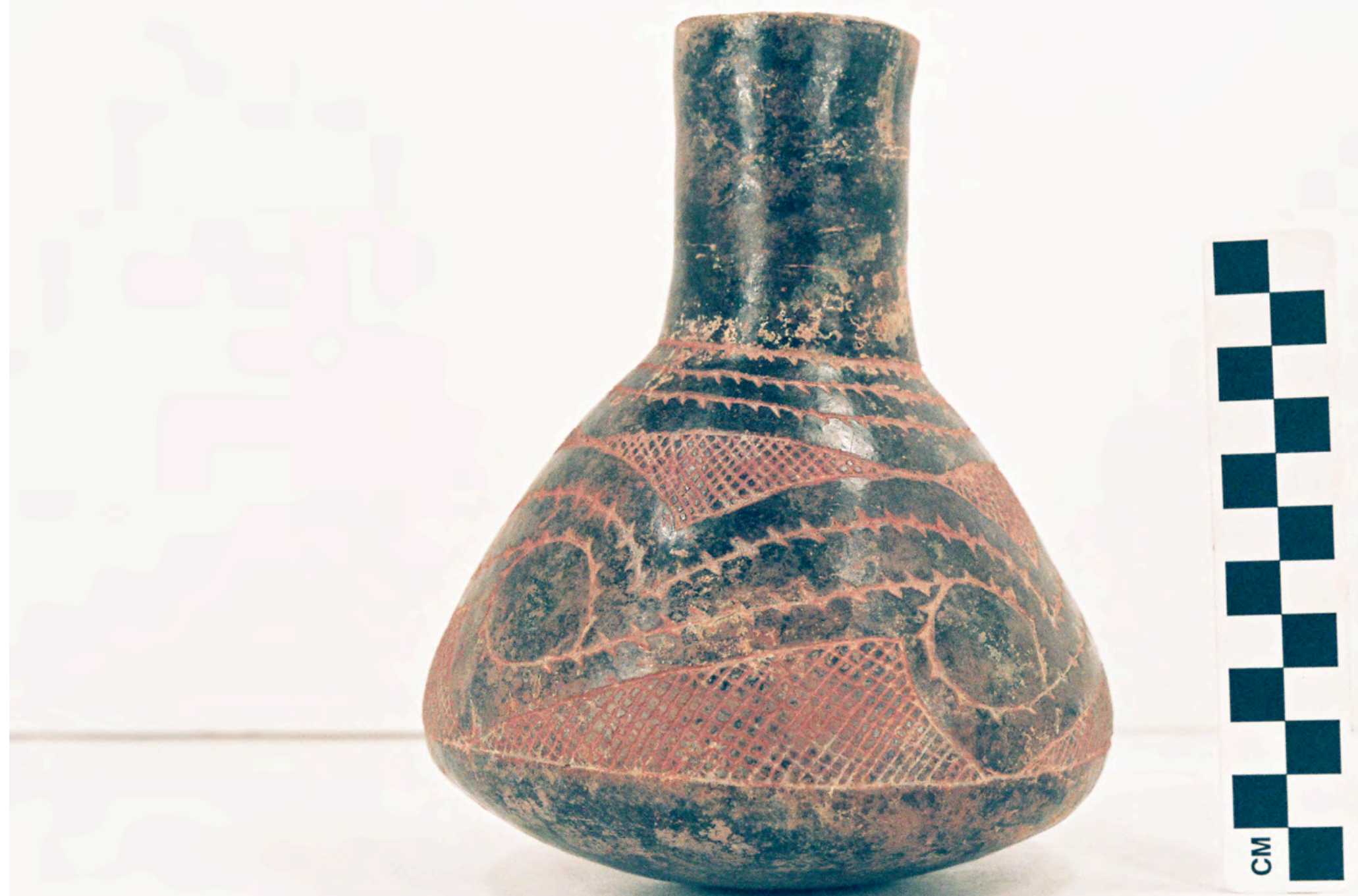

Figure 25e 


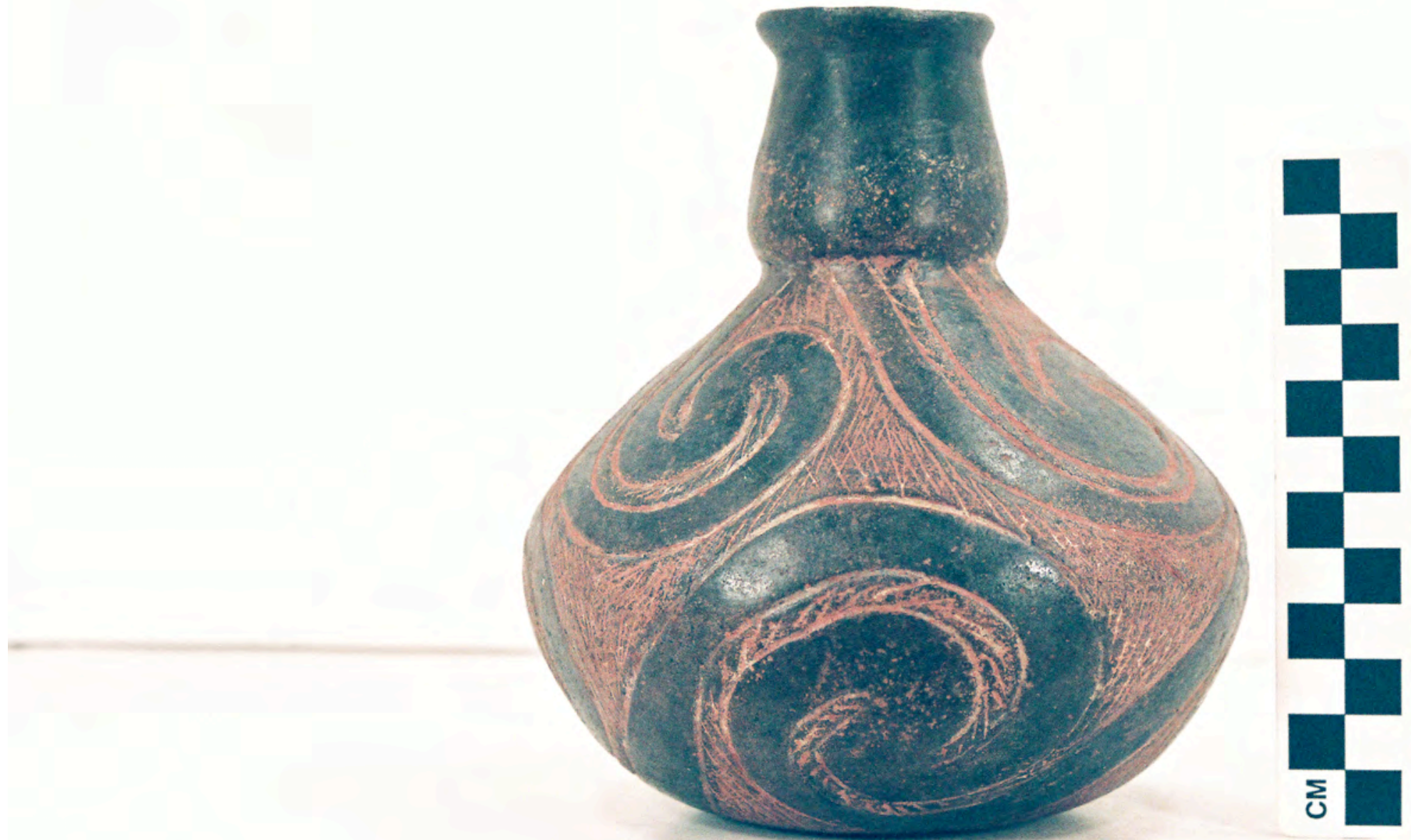

Figure 25f 

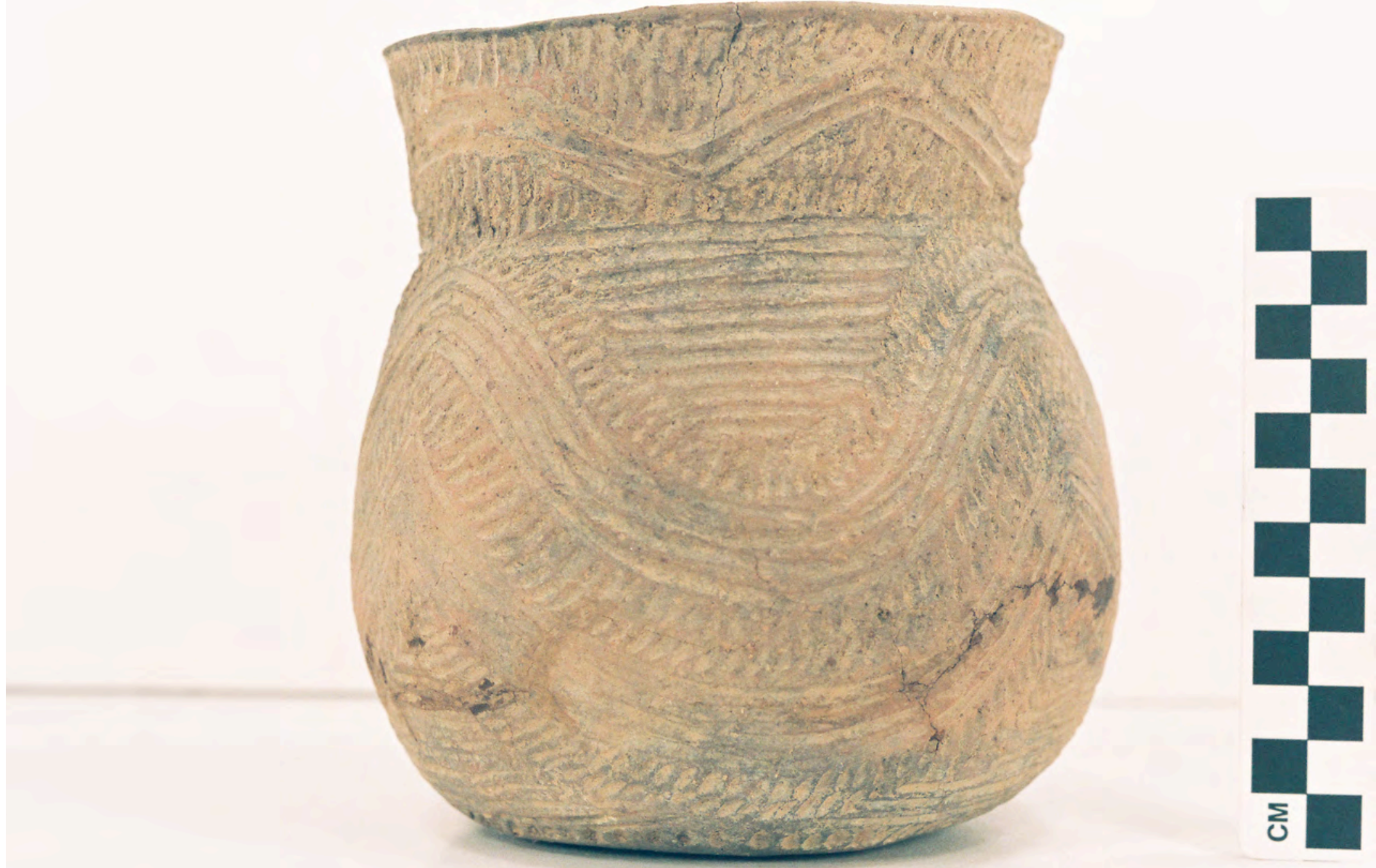

Figure 26 


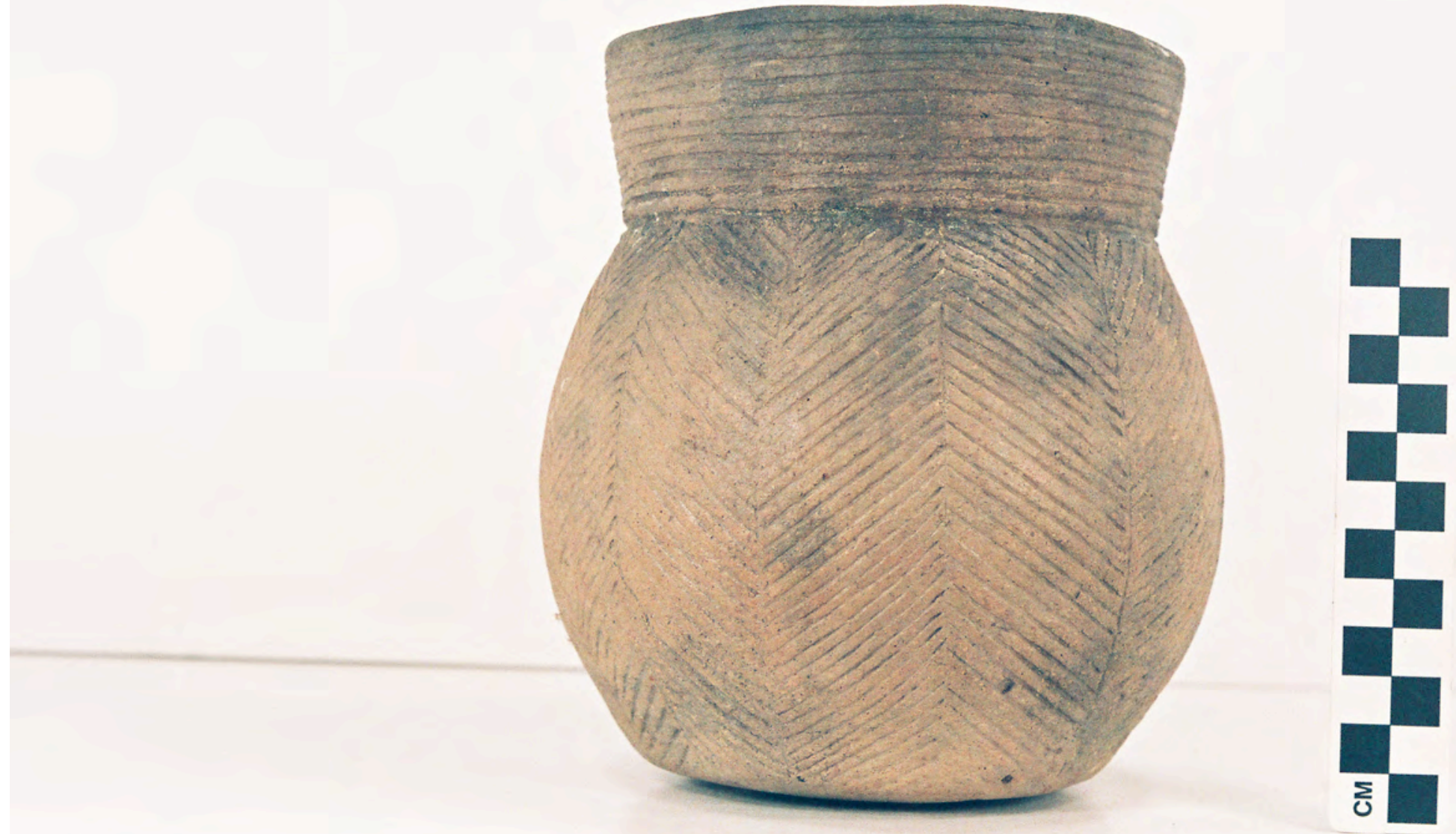

Figure 27 


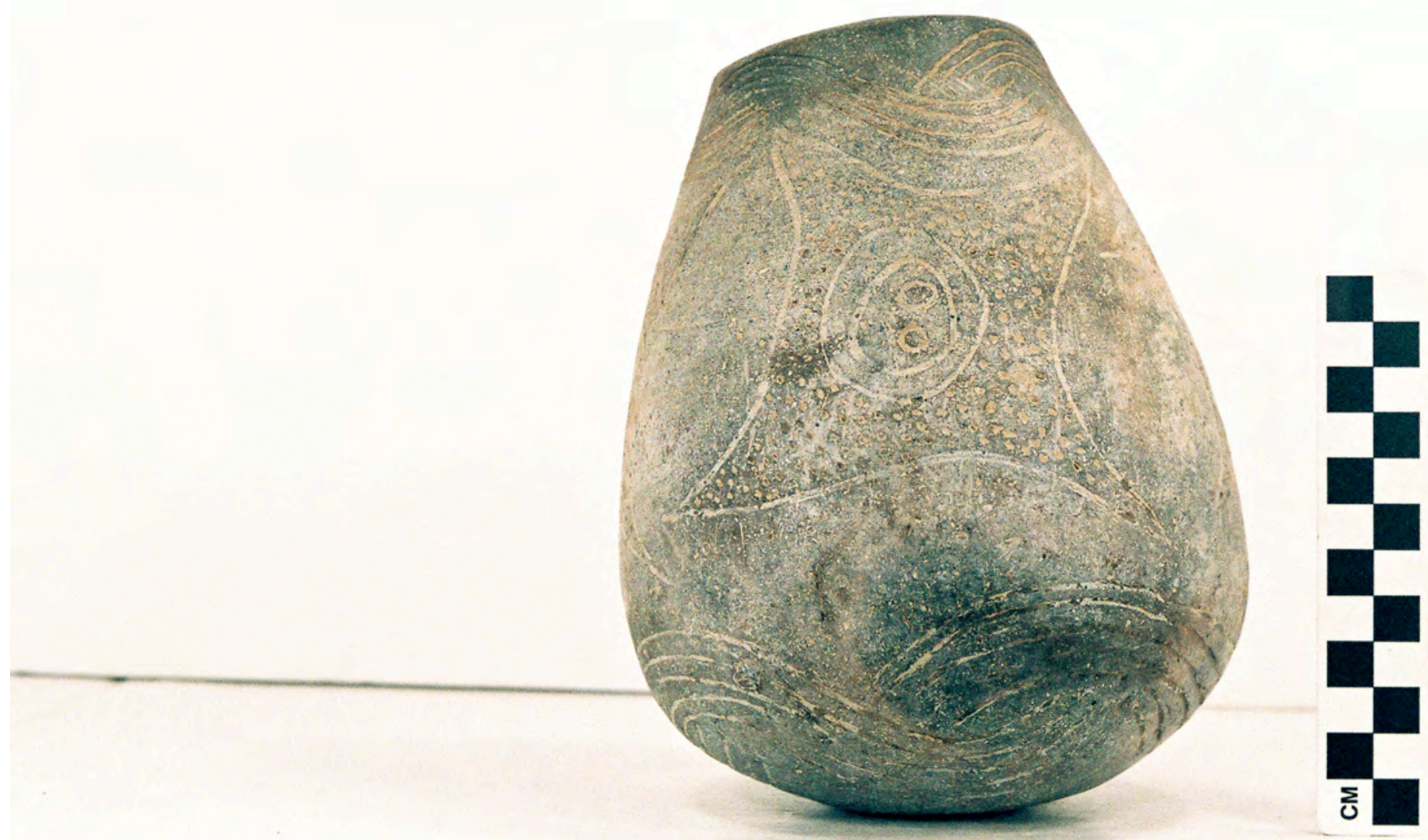

Figure 28 


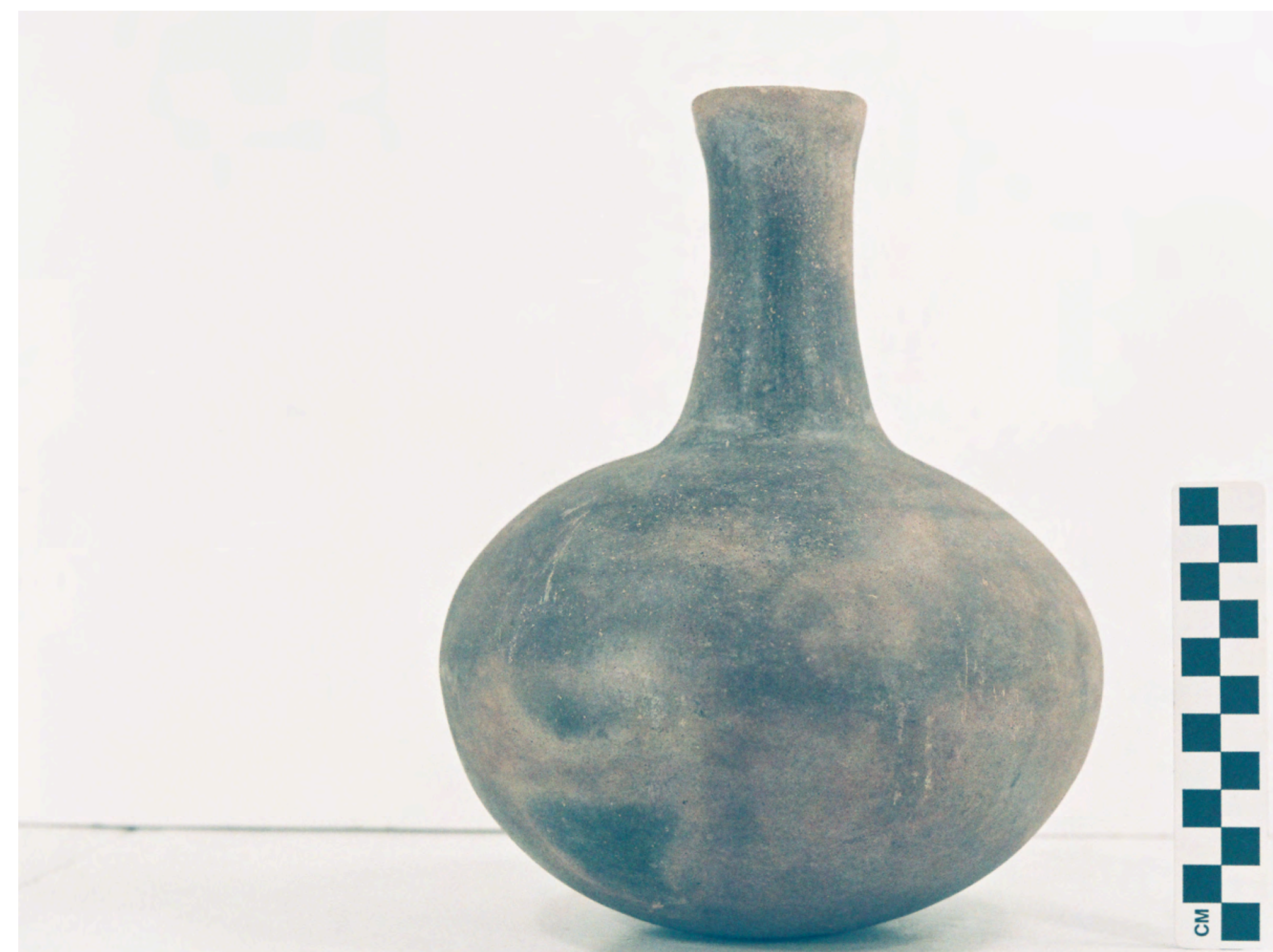

Figure 29a 


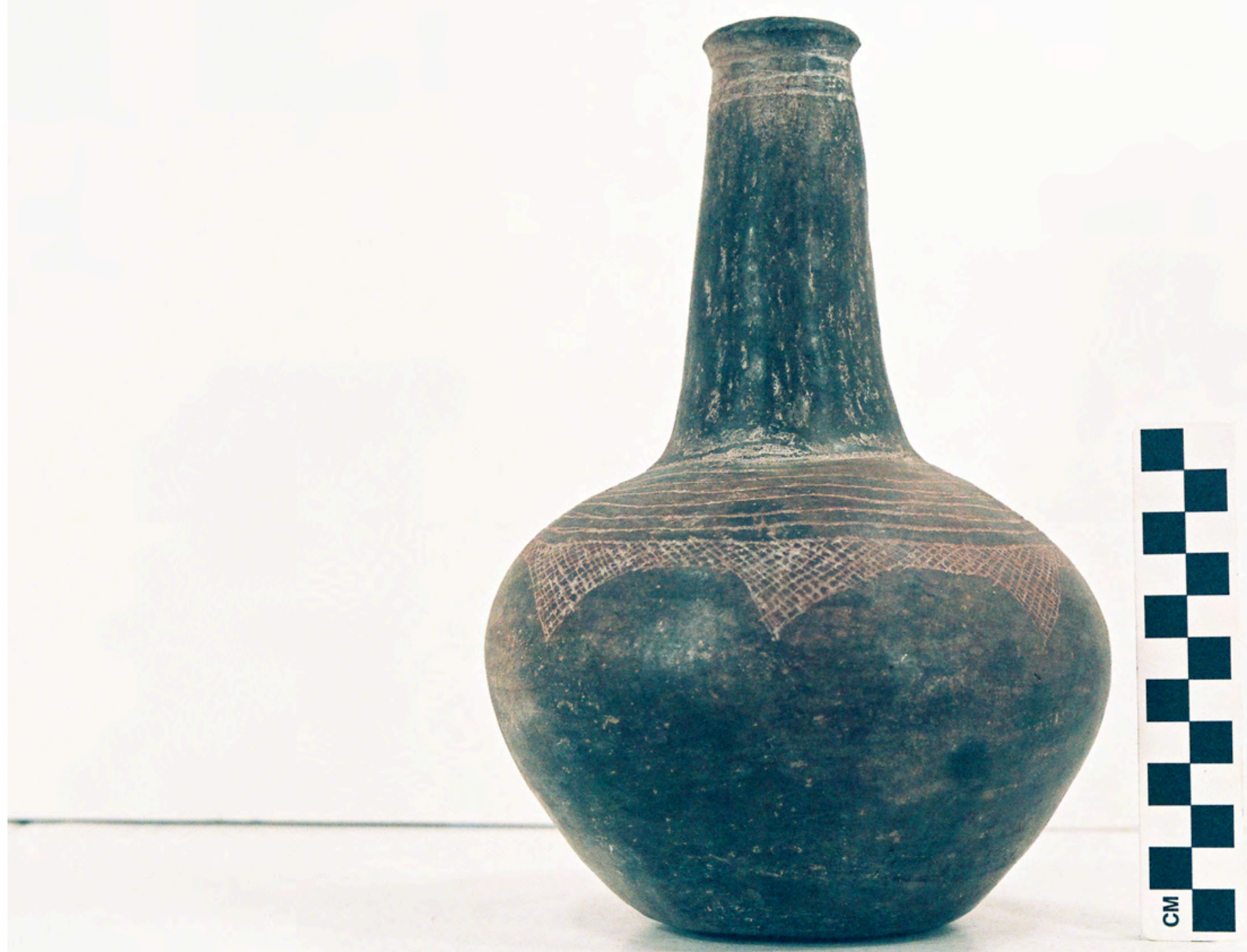

Figure 29b 


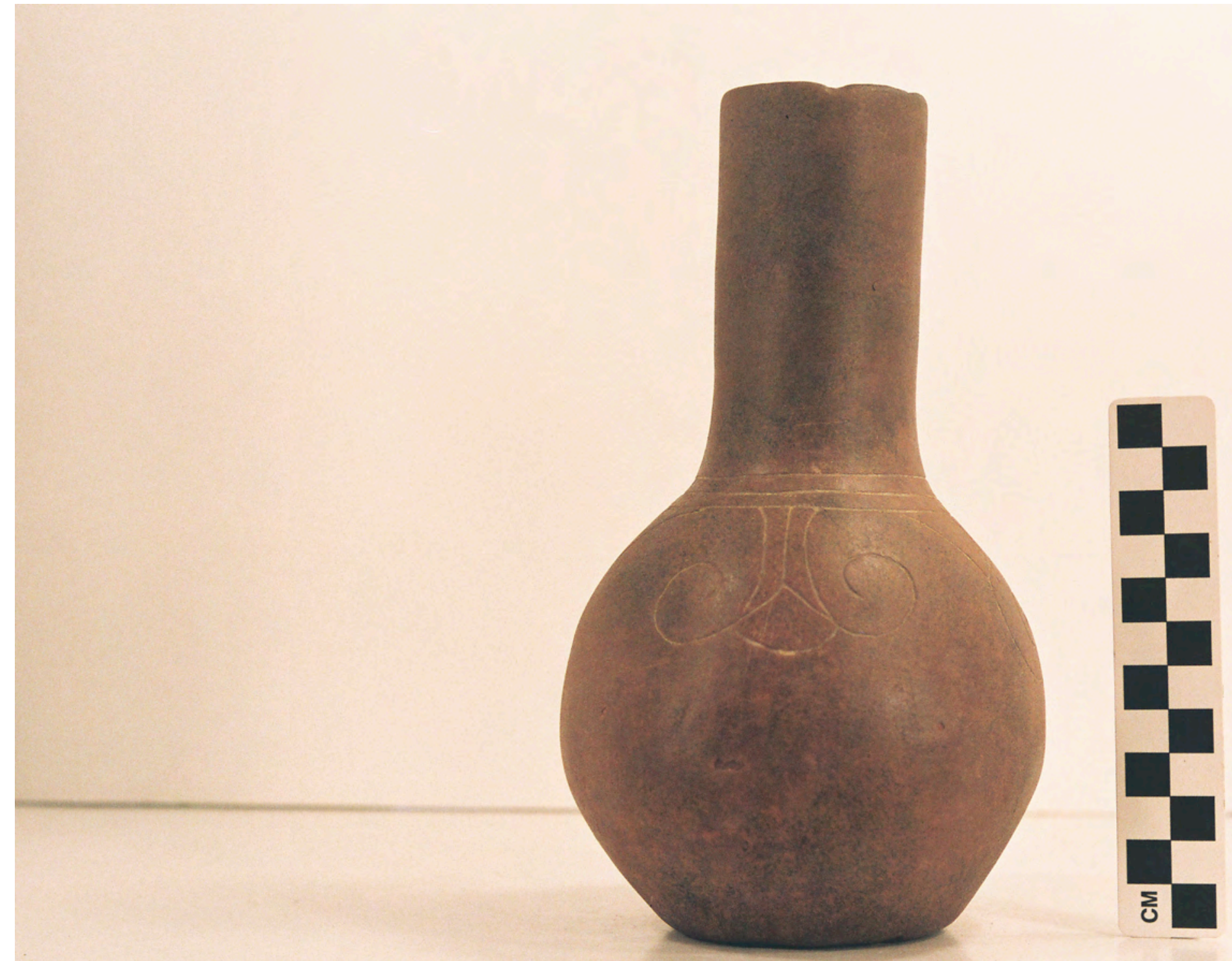

Figure 30 


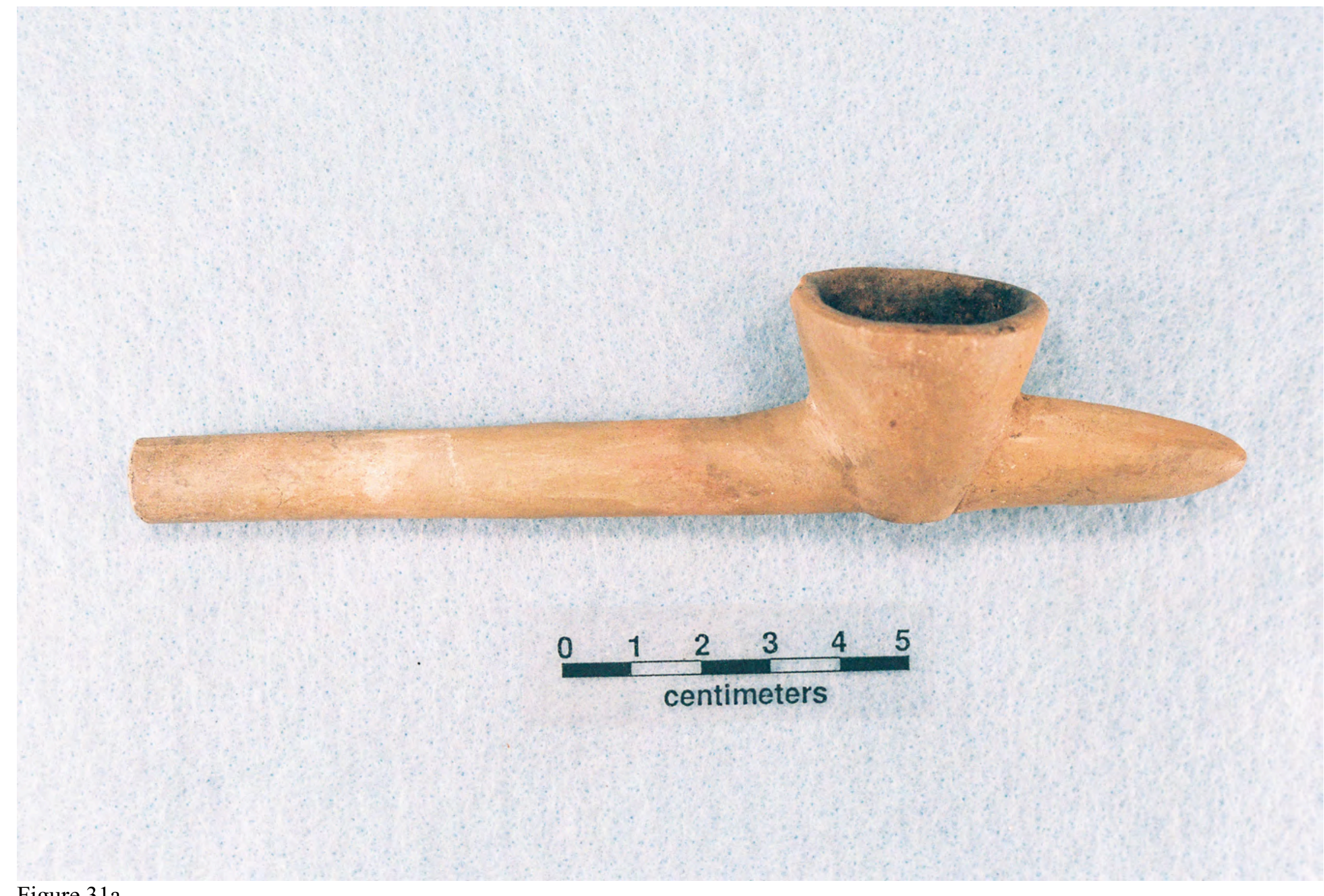

Figure $31 \mathrm{a}$ 


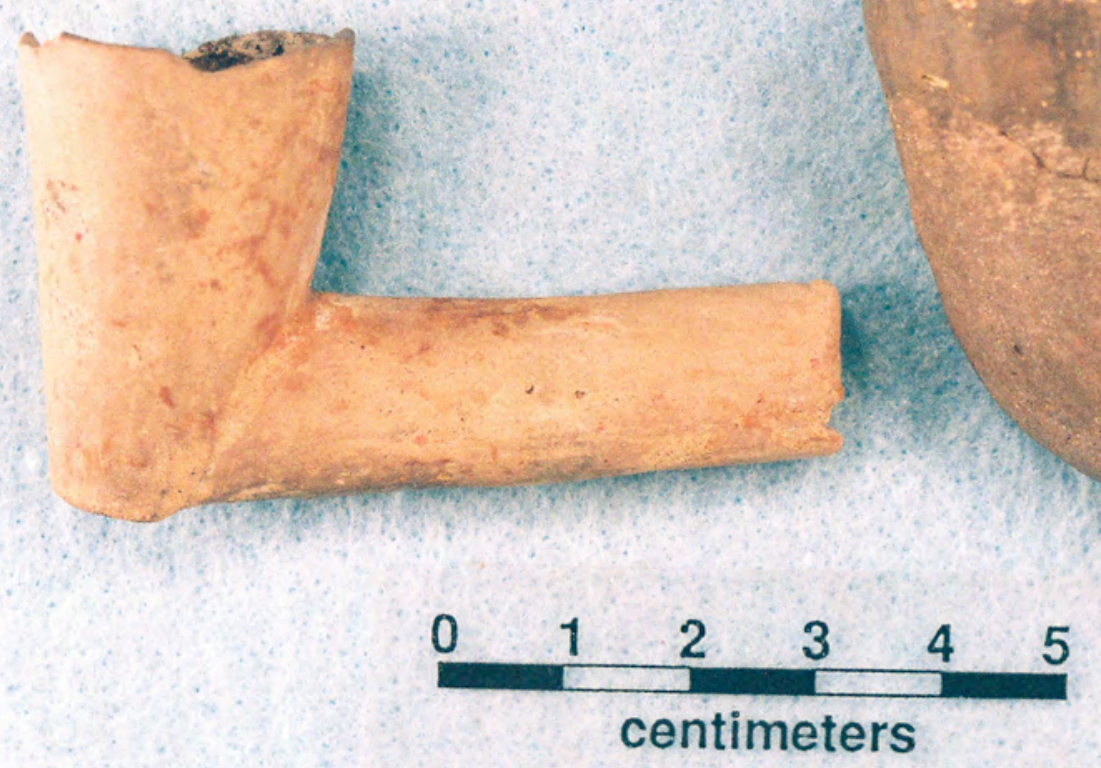

Figure $31 b$ 


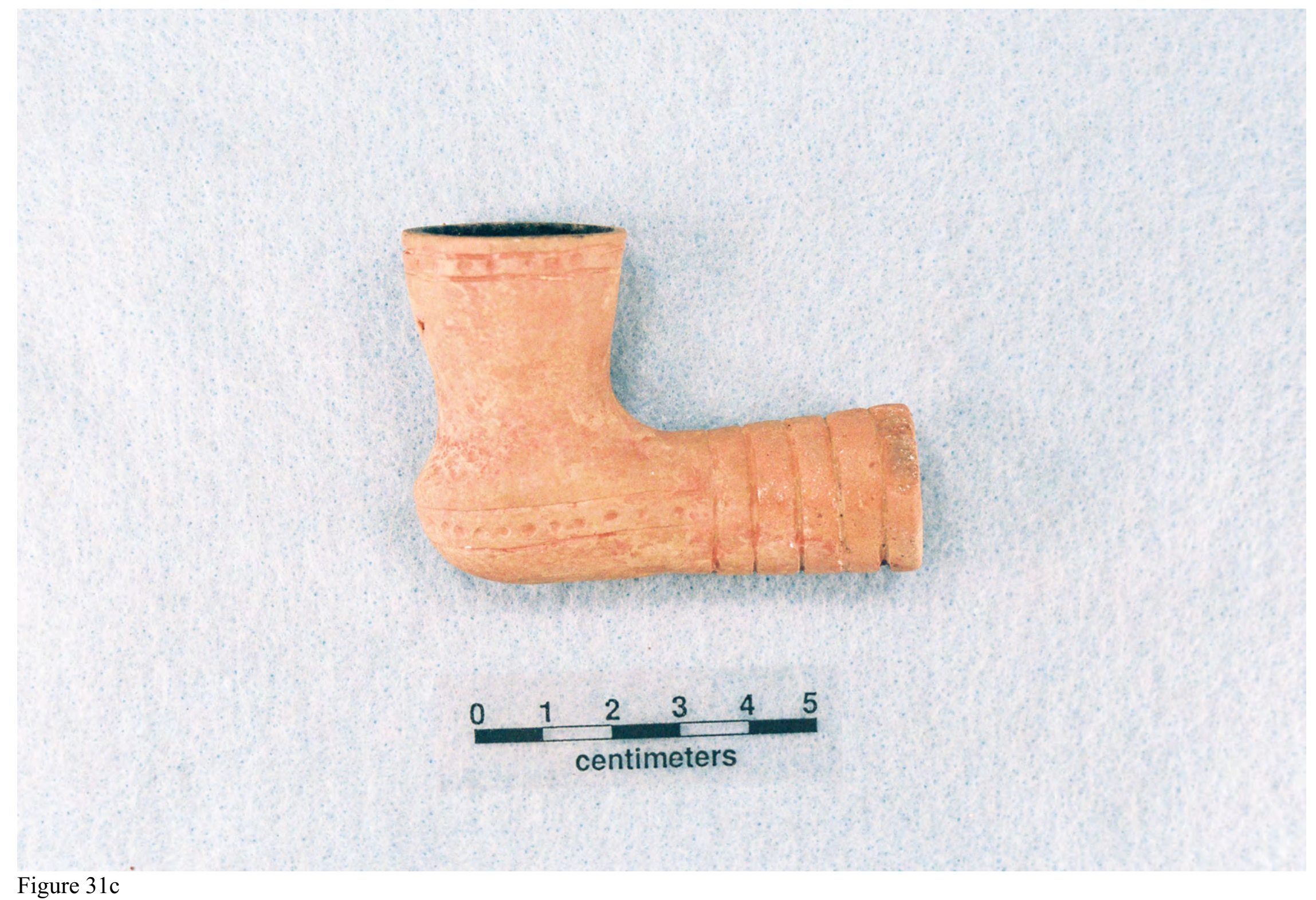

Figure 31c 

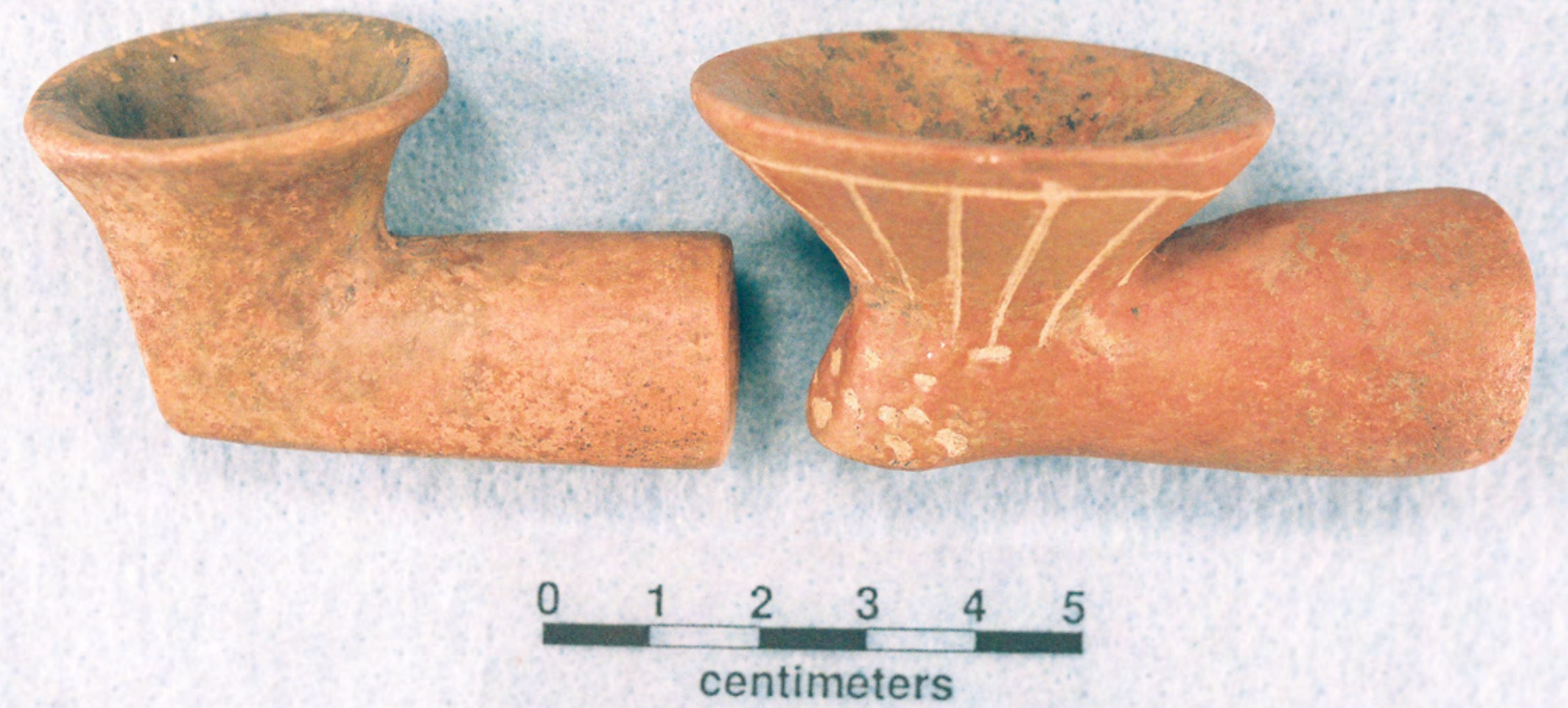

Figure 31d 


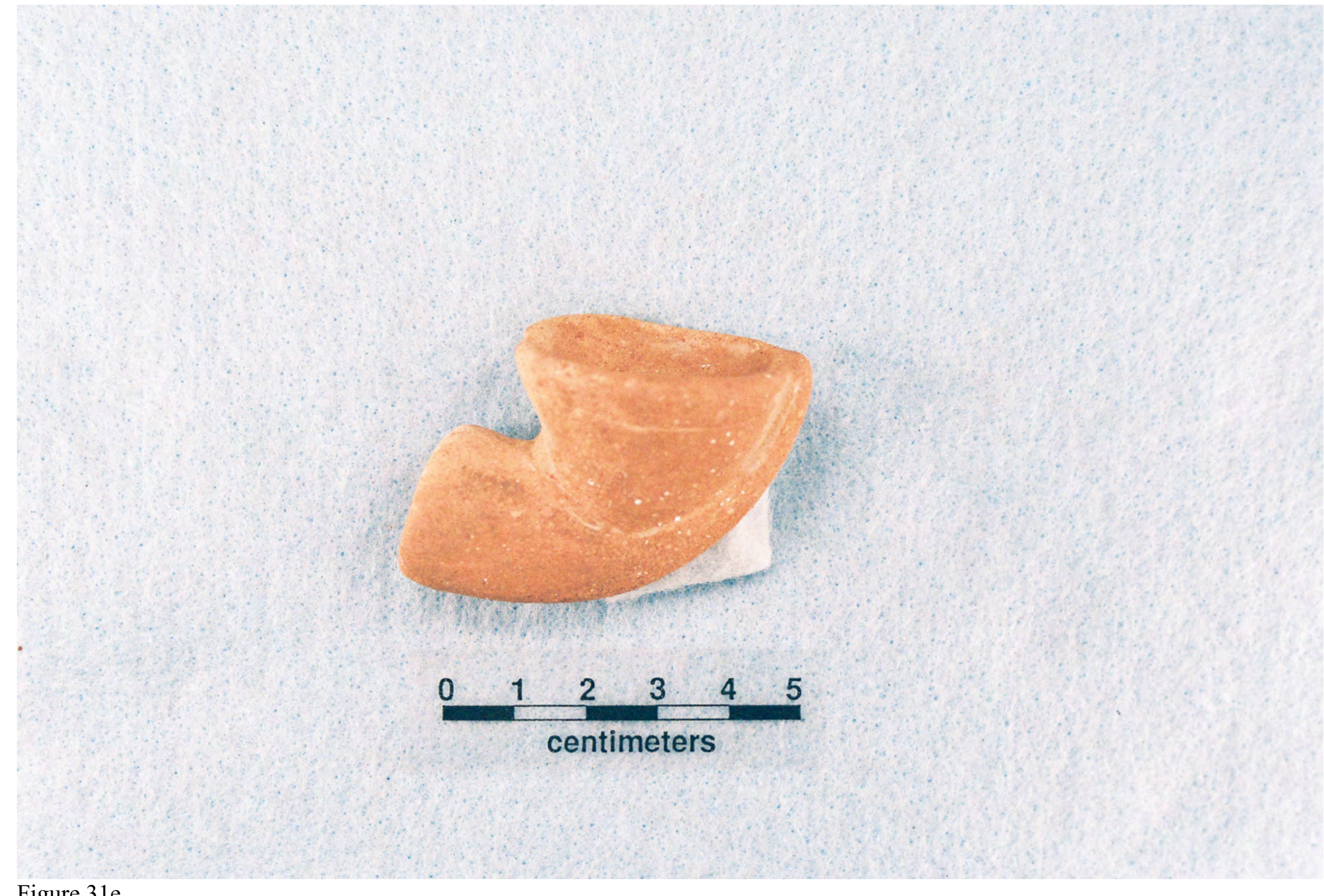

Figure $31 \mathrm{e}$ 